

\section{DIVERSIDADE SEXUAL, ÉTNICO-RACIAL E DE GÊNERO: TEMAS EMERGENTES}

ABEH - Associação Brasileira de Estudos da Homocultura

Ministério da Educação - MEC

Universidade Federal de Mato Grosso - UFMT

NUEPOM

NAPLUS

Fundação Uniselva

\section{Organizadoras(es):}

Bruna Andrade Irineu

Márcio Alessandro Neman do Nascimento

Moisés Alessandro Lopes

Pablo Cardozo Rocon

Danie Marcelo de Jesus

Guilherme Rodrigues Passamani

Jaqueline Gomes de Jesus

Luma Nogueira Andrade

Marco José Duarte

Tatiana Lionço

Brendhon Andrade Oliveira

Jefferson Adriã Reis

Marcos Aurélio da Silva

Gabriel de Oliveira Rodrigues

Editor: Gilmaro Nogueira

Diagramação: Daniel Rebouças

Capista: Alex Pontes

Revisor: Leonardo Coelho Marques de Jesus

\section{Yeditora \\ DEVIRES}

\section{CONSELHO EDITORIAL}

Prof. Dr. Carlos Henrique Lucas Lima

Universidade Federal do Oeste da Bahia - UFOB

Prof. Dr. Djalma Thürler

Universidade Federal da Bahia - UFBA

Profa. Dra. Fran Demétrio

Universidade Federal do Recôncavo da Bahia - UFRB

Prof. Dr. Helder Thiago Maia

Universidade Federal Fluminense - UFF

Prof. Dr. Hilan Bensusan

Universidade de Brasília - UNB

Profa. Dra. Jaqueline Gomes de Jesus

Instituto Federal Rio de Janeiro - IFRJ

Profa. Dra. Joana Azevedo Lima

Devry Brasil - Faculdade Ruy Barbosa

Prof. Dr. João Manuel de Oliveira

CIS-IUL, Instituto Universitário de Lisboa

Profa. Dra. Jussara Carneiro Costa

Universidade Estadual da Paraíba - UEPB

Prof. Dr. Leandro Colling

Universidade Federal da Bahia - UFBA

Profa. Dra. Luma Nogueira de Andrade

Universidade da Integração Internacional da Lusofonia

Afro-Brasileira - UNILAB

Prof. Dr Guilherme Silva de Almeida

Universidade do Estado do Rio de Janeiro - UERJ

Prof. Dr. Marcio Caetano

Universidade Federal do Rio Grande - FURG

Profa. Dra. Maria de Fatima Lima Santos

Universidade Federal do Rio de Janeiro - UFRJ

Dr. Pablo Pérez Navarro

(Universidade de Coimbra - CES/Portugal e Universidade Federal de Minas Gerais - UFMG/Brasil)

Prof. Dr. Sergio Luiz Baptista da Silva

Faculdade de Educação

Universidade Federal do Rio de Janeiro - UFRJ

\section{CIP BRASIL - CATALOGAÇÃO NA PUBLICAÇÃO}

Irineu et. al. -

I68d Diversidade sexual, étnico-racial e de gênero: temas emergentes/Editora Devires. Salvador-BA. $1^{\mathrm{a}}$ edição, 2020

283p.; PUBLICAÇÃO ELETRÔNICA.

ISBN 978-65-86481-21-1

1. Gênero; 2. Sexualidade; 3. Etnicorracial; 4.Homocultura; 5. LGBTI; I. Título.

\section{Realização}

Apoio Institucional

Financiamento
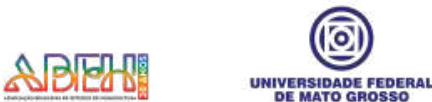

UNIVERSIDADE FEDERAL

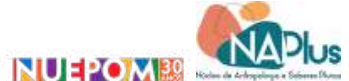

unisctima

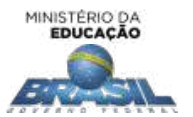




\title{
PREFÁCIO
}

\section{MANIFESTA/O POR UMA EDUCAÇÃO LGBTQI+}

\author{
Por Fátima Lima
}

Mais do que um prefácio, este texto é um/a manifesta/o coletiva/o. Escrito por várias mãos, ele também é polifônico. Somos muitas/os/es. Visíveis e invisíveis. Uma multitude LGBTQI+ que atravessa esses brasis de forma plural. Em movimento sempre, as identidades só nos interessam enquanto ferramenta política. Este texto foi escrito em um tempo pandêmico. Tomados pela pandemia do SARS-coV-2, sabemos muito bem quais os corpos que não resistiram e que não tiveram acesso ao privilégio da quarentena e dos cuidados necessários para prevenir a contaminação. $O$ vírus pode atingir todas/os/es, mas a distribuição das vulnerabilidades é desigual. A comunidade LGBTQI+, de diferentes formas, foi severamente atingida pela pandemia que fez ver e dizer as assimetrias e brutalidades que perpassam nossos cotidianos.

Mas este é também um texto de celebração. Celebremos nossas existências. Celebremos nossas persistências ao tempo dos assassinos/ as que tem no cisheteropatriarcado racista/classista/neoliberal seu lugar de hegemonia. Celebremos 20 anos de existência da Associação Brasileira de Estudos da Homocultura - ABEH por congregar, ao longo de suas duas décadas de existência, pesquisadoras/es LGBTQI+, bem como as temáticas que se relacionam à diversidade de gênero, sexual e étnico-raciais coadunando um profícuo espaço de produções intelectuais, artísticas e militantes, pois sabemos desde muito tempo que as epistemo-metodologias são indissociáveis da vida e, portanto, das posições e atuações políticas. 0 conhecimento que produzimos é encarnado, corporificado, atravessado por dores, mas também por purpurinas, pois aprendemos que gargalhar é 
um ato de afronta a tudo o que tenta nos assujeitar, violentar, subjugar e exterminar.

O livro que segue nas próximas páginas "Diversidade Sexual, ÉtnicoRacial e de Gênero - Temas Emergentes" é uma arma de guerra coletiva. Uma ferramenta forjada na implicação e no compromisso com as produções acadêmicas no campo, mas principalmente implicadas com as vidas na/ da comunidade LGBTQI+. Cada escrita ofertada é uma oferenda, uma conspiração, uma conjuração a esse tempo e suas marcas de violências étnico-raciais, de gênero, sexuais entre outras. É também um somatório de forças, um sim à vida. Márcio Alessandro Neman do Nascimento, Bruna Andrade Irineu, Brendhon Andrade Oliveira, Jefferson Adriã Reis, Abayomi Jamila, Dani Lebinski, Joe Sales, Francis de Lima Aguiar, Luma Nogueira Andrade, Jaqueline Gomes de Jesus, Milena Carlos Lacerda, Moisés Lopes, Amanda Bravo Pereira Almeida, Lissa Carvalho de Souza, Maria Carolina Kovaleski Ferreira, Marco José de Oliveira Duarte, Dandara Felícia Silva Oliveira, Késia Mayra Rodrigues Ignácio, María Antonella Barone, Alexsandro Rodrigues, Pablo Cardozo Rocon, Ana Paola de Souza Lima, Danie Marcelo de Jesus, Guilherme R. Passamani, Marcelo Victor da Rosa, Jônatas Stritar Alaman, Tatiana Bezerra Lopes, Benjamin Braga Neves, Lorena Lopes de Oliveira, Tatiana Lionço, Sara Wagner York, Bruna Benevides, Megg Rayara Gomes de Oliveira, Manifesta Lésbico-Feminista, Fátima lima oferecem reflexões pertinentes, ferramentas de lutas, rotas de fuga. Gratidão. Axé!

Eis nossas vociferações:

1) Uma Educação $L G B T Q I+$ é uma posição política, ética e estética frente aos mundos. Não é sobre identidade. É sobre práticas políticas identitárias que só adquirem importância quando nossa nomeação é, antes de tudo, uma nomeação política e coletiva. Por isso, nos nomeamos lésbicas, sapatonas, gays, bichas, trans, travestis, entre outras/os/es. Sob outras perspectivas, também temos o direito de não nos nomearmos.

2) Apostar numa educação $L G B T Q I+$ implica o compromisso com os modos de vidas, com as existências, com os viventes aqui incluindo todos os seres vivos. Portanto, encontra-se ligada à vida numa dimensão planetária e num encontro com a terra-mãe e suas agonias contemporâneas. Gaia ó nosso lugar. Só há esse mundo. Toda pessoa LGBTQI+ quer ter direito a este mundo. Faz parte da terra-mãe.

3) Uma educação LGBTQI+ entende que não somos iguais, que vivemos as experiências, sensações, desejos de forma plural e singular e que precisamos 
combater as lesbofobias tanto quanto as homofobias e transfobias no âmbito coletivo, tanto quanto em nossas experiências singulares.

4) Uma educação LGBTQI+ reconhece os eixos de opressões e se coloca frente a frente no combate a qualquer tipo de opressão ou violência seja ela de gênero, de sexualidade, de classe, de raça, geracional, territorial, entre outras; entendendo que estes eixos de opressão constituem relações de poder sobre corpas/ossubjetividades com a finalidade de categorizar, hierarquizar, docilizar, controlar, subjugar e desumanizar. Nosso compromisso é perceber, refletir e se posicionar frente aos eixos de opressão, muitas vezes, interseccionalizados.

5) Uma educação LGBTQI+ reconhece a CISHETERONORMATIVIDADE PATRIARCAL E RACISTA como uma matriz de inteligibilidade perversa e combate suas violências cotidianas. Assim, se coloca contra a força violenta da cisheteronormatividade compulsória que tenta controlar e violentar nossas corpas-subjetividades.

6) Uma Educação LGBTQI+ é antirracista, antissexista e anticapitalista. Se compromete - num país como nosso - a combater as colonialidades reatualizadas e operantes, principalmente a colonialidade de gênero e o racismo que modelam as práticas e discursos cotidianos.

7) Uma educação LGBTQI+ é anticolonial. Nesse sentido, combate a supremacia branca entendida como um lugar hegemônico de poder, de nomeação e de violências.

8) Uma educação LGBTQI+ se compromete a questionar qualquer dado ou pesquisa que não leve em consideração as lesbianidades, homossexualidades, travestilidades, transexualidades, intersexualidades, bem como outras expressões dissidentes de gênero e sexualidades e suas singularidades como uma forma necessária de ol har e combater as diferentes violências. Por isso nos interessam as políticas raciais, de gênero e sexualidades.

9) Uma educação LGBTQI+ reconhece a pluralidade de nossas construções corporais, não se prendendo ao que culturalmente se instituiu como 'feminilidades' e 'masculinidades', ou seja, se toma das possibilidades de corporeidades e combate os estigmas e preconceitos, bem como as essencializações das/os/es que enfrentam a força compulsória de cisheronormatividade. Destarte, abnega o determinismo biológico e o dismorfismo sexual que agridem e violentam, principalmente, as pessoas intersexos.

10) Uma educação $L G B T Q I+$ tem como meta a visibilidade que é diferente da exposição. Visibilidade é, antes de tudo, sobre nos mantermos vivas. E para nos mantermos vivas precisamos ser estratégicas/os, precisamos criar rotas de fuga, fortalecer nossas ideias, nosso em-comum. 
11) Uma educação $L G B T Q I+$ reconhece que temos trajetórias diferentes, que enfrentamos as nossas experiências de formas diferentes e, que, muitas vezes, o segredo e o silêncio nos mantém vivas/os/es. Repito: o segredo e o silêncio, muitas vezes, nos mantêm vivas/os/es. Não é sobre silenciamentos. É sobre o silêncio e sua agência.

12) Uma educação LGBTQI+ contempla as maternidades/paternidades lésbicas, gays, travestis, transexuais e intersexuais.

13) Uma educação LGBTQI+ aposta em uma universidade mais plural, aberta, que realmente faça valer seu sentido incorporando em suas dinâmicas a polissemia e polifonia de teorias bem como de ideias, ampliando as vozes LGBT+ nas produções epistemológicas quanto nas vivências cotidianas nos espaços ditos acadêmicos.

14) Uma educação $L B T Q I+$ traz para o centro do debate as diferentes experiências em contextos de comunidades, favelas, periferias, espaços rurais, quilombolas, ribeirinhos, entre tantos outros que tornam visiveis e dizíveis a pluralidade de nossas existências bem como os desafios que cada singularidade dessa demanda no exercício cotidiano de existir como se deseja existir.

15) Uma LGBTQI+ celebra as nossas existências, reafirma o amor à vida e a liberdade, entendendo que a liberdade nossa move todas as liberdades.

Dedico este breve manifesta/o à todas/os/es que foram brutalmente atingidas/os/es e, muitas vezes, exterminadas/os/es pelo necropoder e pela bio-necropolítica genderizada.

\section{Fátima Lima}

Sapatão, nordestina, negra. Professora associada da UFRJ/ Campus Macaé. Ativista.

Professora do Programa Interdisciplinar de Pós-Graduação em Linguística Aplicada/ PIPGLA/UFRJ. Professora do Programa de Pós-Graduação em Relações Étnico-Raciais/ PPRER/CEFET/RJ. Colaboradora da ONG 'Casa das Pretas'. Coordenadora do ORÍ - grupo de estudos e pesquisas em raça, gênero e sexualidade. Filiada a Associação Brasileira de Estudos da Homocultura - ABEH. 


\section{SUMÁRIO}

APRESENTAÇÃO

Márcio Alessandro Neman do Nascimento

Bruna Andrande Irineu

Brendhon Andrade Oliveira

Jefferson Adriã Reis

\section{PARTE I - A(R)TIVISMOS, MEMÓRIAS E RESISTÊNCIAS}

20 ANOS DE ABEH: CO-PRODUÇÕES ATIVISTAS, ACADÊMICAS E ARTÍSTICAS

Bruna Andrade Irineu

POEMA: AS COISAS

Abayomi Jamila

POEMAS: DICOTOMIA/AMOR PROIBIDO/RESQUÍCIOS

Dani Lebinski

MICRONARRATIVA: A COLEIRA DO CÃO

Francis de Lima Aguiar

POEMA: DO COTIDIANO NA MESA/CONTO: QUANDO A MACUMBA PEGA NA GENTE Joe Sales

CONTO: TUBAÍNA

O EXERCÍCIO DA PARRESÍA NO RELATO DE MIM MESMA: O QUE SE PASSA COMIGO OU O QUE SE PASSA CONOSCO?

Tatiana Lionço

\section{PARTE II - DEMOCRACIA, POLÍTICAS PÚBLICAS E DIREITOS}


UM BALANÇO CRÍTICO ACERCA DA REGRESSÃO DOS DIREITOS LGBTI

NO BRASIL SOB ASCENSÃO DO BOLSONARISMO

Bruna Andrade Irineu

Brendhon Andrade Oliveira

Milena Carlos Lacerda

A CONSTRUÇÃO DA CIDADANIA E DAS POLÍTICAS PÚBLICAS PARA LGBTS NO CENTRO-OESTE DO BRASIL

Moisés Lopes

OS ASPECTOS PSICOSSOCIAIS DO ATENDIMENTO DE MULHERES, LGBT+ E CRIANÇAS NA DEFENSORIA PÚBLICA - NÚCLEO CRIMINAL DO MUNICÍPIO DE RONDONÓPOLIS

Márcio Alessandro Neman do Nascimento

Amanda Bravo Pereira Almeida

Lissa Carvalho de Souza

Maria Carolina Kovaleski Ferreira

\section{PARTE III - ALIANÇAS, ESTRATÉGIAS E RESSIGNIFICAÇõES}

GÊNERO, RAÇA E SEXUALIDADE: UMA PROPOSTA DE DEBATE INTERSECCIONAL?

Ana Paola de Souza Lima

Danie Marcelo de Jesus

PROSTITUIÇÃO MASCULINA EM CONTEXTOS TRANSNACIONAIS:

PROJETOS, CAMPOS DE POSSIBILIDADES E AGÊNCIA EM LISBOA

Guilherme R. Passamani

Marcelo Victor da Rosa

Jônatas Stritar Alaman

Tatiana Bezerra Lopes 
O FUNK CARIOCA E O DOM DE VISIBILIZAR CULTURAS E IDENTIDADES: QUANDO A REPRESENTATIVIDADE TRANSFORMA O SOCIAL (?)

Benjamin Braga Neves

BRICOLAGEM PARENTAL: ANÁLISE CARTOGRÁFICA FÍLMICA DE FILIAÇÃO NA CONFIGURAÇÃO FAMILIAR SINGULAR APRESENTADA EM PATRIK1.5 Lorena Lopes de Oliveira

Márcio Alessandro Neman do Nascimento

\section{PARTE IV - MANIFESTOS POR OUTROS FUTUROS POSSÍVEIS}

Turma 2020 do curso Teorias Feministas e Lesbianidades

MANIFESTO TRAVESTI

266

Sara Wagner York

Bruna Benevides

Megg Rayara Gomes de Oliveira 


\section{APRESENTAÇÃO}

Ao completar 20 anos de construção de saberes acadêmicos, militância, experiências e compartilhamentos, a Associação Brasileira de Estudos da Homocultura (ABEH) demonstra o amadurecimento dos estudos de diversidade sexual e de gênero no Brasil. A ressonância da perspectiva interseccional, atenta à necessária correlação entre sexualidade, gênero, raça, etnia, geração, classe social e outros marcadores sociais da diferença, vai arregimentar este solo fértil que se constituiu essa área interdisciplinar do conhecimento.

O investimento na criação de uma Revista, como a REBEH - Revista Brasileira de Estudos da Homocultura, no ano de 2018, assim como a consolidação de um Congresso Internacional, como o CINABEH - Congresso Internacional da $\mathrm{ABEH}$, que em 2021 fará sua décima edição, apontam para a maturidade da associação e do conjunto de pesquisadoras e pesquisadores a ela filiadas e filiados.

As transformações na dinâmica da associação podem ser percebidas no fato de termos visto uma presidência da ABEH nas mãos de uma pesquisadora travesti situada em uma universidade originada pela Reforma Universitária e na região Nordeste do país, nos anos 2017 e 2018, até a passagem daquela gestão para a atual, ocorrida entre 2019 e 2020, presidida por uma pesquisadora lésbica e oriunda de uma universidade do Centro-Oeste e na região do Pantanal, marcada pelo incentivo empresarial ao agronegócio e pela negligência com a formação humana inerente às Ciências Humanas e Sociais.

A circulação das produções acadêmicas fora dos grandes centros, ou no que chamamos de periferia da produção de conhecimento brasileira, é também um compromisso desse livro, que vai reunir textos de pesquisadoras e de pesquisadores vinculados às universidades do Centro-Oeste, mas não somente. Entre margens e centro, no sentido foucaultiano, veem-se alianças, responsabilidade e compromisso em comunicar e socializar o que também se produz fora do eixo. 
Considerando esta trajetória, no texto 20 anos de $A B E H$ : co-produções ativistas, acadêmicas e artísticas, de autoria de Bruna Andrade Irineu, são apresentadas a história e as memórias que co-produziram o campo dos estudos de diversidade sexual e de gênero no Brasil. Desde a consolidação de um campo, que vivenciou as interpéries da epidemia de AIDS, mobilizando processos que foram fundamentais no desenvolvimento das políticas de saúde e educação no Brasil e que determinaram, décadas depois, as recentes decisões jurídico-legais e a formulação de políticas específicas para população LGBTI, hoje sob ameaças reais de regressão. A relevância histórica da $A B E H$ é defendida e celebrada não apenas pela produção de saberes, mas especialmente pela circulação de afetos e corpos desejantes de uma ciência engajada com a construção de outros modos de ser e existir.

Retornando às suas origens, nas letras, a ABEH publica neste livro comemorativo, além dos trabalhos acadêmicos, algumas obras literárias que, com a sensibilidade da Literatura, abrem os trabalhos. São poemas e prosas que brotam de experiências e vivências afetivas e sexuais dissidentes e revelam a vida em sua potência imagética, criativa e sensível. A Literatura, principalmente em tempos sombrios como o que vivemos, é uma máquina de guerra, nas palavras de Gilles Deleuze e Félix Guattari, isso significa que traz em si a capacidade de movimentar as coisas, desestabilizar as estruturas e de fazer verter as vozes e os rostos.

No poema As coisas, Abayomi Jamila nos convida a imaginar como seria se as coisas fossem mais simples, como o brilho do amor na pele; nos poemas Dicotomia, Amor proibido e Resquícios, Dani Lebinski explora os efeitos do amor, sobretudo de amores malditos; na micronarrativa A coleira do cão, de Francis de Lima Aguiar, um cão vivencia a sombra de uma árvore e o comprimento da corrente que o prende; no poema Do cotidiano na mesa e no conto Quando a macumba pega na gente, Joe Sales faz de homo-amores a semente de onde germina sua expressão de vida; e no conto Tubaína, de Jefferson Adriã Reis, um menino interiorano descobre as delícias dos corpos e das imagens.

Tatiana Lionço em "O exercício da parresía no relato de mim mesma: o que se passa comigo ou o que se passa conosco?", parte do conceito de 'parresía', apoiado em Butler (2015) e Foucault (2011), para 'relatar a si' (ou seja, a partir de sua experiência social localizada) num processo em que se considera e revela os interesses da coletividade. Ela divide seu relato 
em três momentos: a imposição normativa, o caminho da censura e o caminho da vergonha. Assim, mais que relatar os exercícios profissionais da autora, que é professora e psicóloga, o texto almeja desvelar estratégias fundamentalistas religiosas na política nacional, bem como as resistências a essa força antidemocrática, num ímpeto de sensibilizar e mobilizar o comprometimento coletivo diante das ofensivas conservadoras.

Luma Nogueira de Andrade compartilha sua experiência enquanto presidenta da Associação Brasileira de Estudos da Homocultura (ABEH), entre 2017 e 2018, em "A gestão da ABEH entre o golpe e a facada". A autora reflete sobre o período histórico, que se encontra entre o impedimento de Dilma Rousseff e as estratégias utilizadas na criação do "Messias", que culmina na eleição de Jair Bolsonaro, cujo cenário impactou nas ações desenvolvidas pela gestão da ABEH. Sob o comando de Luma, a ABEH enfrentou a crescente "nova direita", podendo citar como exemplo a realização do IX Congresso Internacional da ABEH no Ceará, com o tema articulando Brasil-África, raça, gênero e sexualidade. Há que se ressaltar que foi nesse momento em que a primeira mulher trans passa a diretoria para a primeira mulher lésbica presidenta, a Prof. ${ }^{a}$ Bruna Irineu. A autora conclui que entre "golpes e facadas" a comunidade segue sangrando no enfrentamento e na resistência.

Em Gestão da Diversidade no Brasil: notas críticas, Jaqueline Gomes de Jesus, contextualizando a realidade nacional, apresenta notas introdutórias sobre a gestão da diversidade à luz dos desafios para a implementação desse campo de atuação no mundo do trabalho brasileiro. Para a autora, a diversidade humana é o conjunto de relações interpessoais e intergrupais em um determinado sistema social, portanto, a gestão da diversidade se constitui como uma área de pesquisa e intervenção organizacional que tem como objetivo primordial a inclusão de pessoas oriundas de diferentes grupos e identidades sociais diversas em um ambiente complexo.

No texto Um balanço crítico acerca da regressão dos direitos $L G B T I$ no Brasil sob ascensão do Bolsonarismo: apontamentos preliminares à luz da Teoria Social Crítica, as/os autoras/es Bruna Irineu, Brendhon Andrade e Milena Lacerda refletem sobre o avanço da Nova Direita no Brasil atual, observando a conjugação das concepções de neoliberalismo e de neoconservadorismo. As/os autoras/es analisam a 'cruzada antigênero' na agenda da extrema direita com a ascensão vertiginosa do bolsonarismo, que vem alinhada a retrocessos no campo dos direitos sociais e no âmbito da 
política interna de Direitos Humanos, sobretudo no que se refere às políticas públicas LGBTI.

No trabalho A construção da cidadania e das Políticas Públicas para LGBTs no Centro-Oeste do Brasil, quinto capítulo deste livro, Moisés Lopes, considerando as implicações das grandes regiões brasileiras, identifica que o cenário centro-oestino não se difere em grande medida do cenário nacional nos últimos 15 anos, onde se avançou no reconhecimento da cidadania LGBTI. Todavia, nos alerta para a expansão do fundamentalismo religioso, cujo poder objetiva o fim de um Estado que promove direitos humanos e sociais. $O$ capítulo ainda apresenta os caminhos metodológicos desta vasta pesquisa, bem como os dados coletados.

Em Os aspectos psicossociais do atendimento de mulheres, LGBT+ e crianças na Defensoria Pública - Núcleo Criminal do município de Rondonópolis, Márcio Neman, Amanda Almeida, Lissa de Souza e Maria Carolina Ferreira dissertam a respeito de algumas especificidades acerca das demandas encaminhadas à Defensoria Pública de Rondonópolis e que foram atendidas por estagiárias/os e extensionistas do curso de Psicologia, na Clínica Ampliada. Tendo em vista que as buscas por atendimento psicossocial se deram, principalmente, por conta de casos de violência de gênero e violência sexual, as/os autoras/es se aprofundam em detalhes documentados na bibliografia sobre violência de gênero contra mulheres, violência sexual infantojuvenil e, por fim, demandas variadas de pessoas $\mathrm{LGBT+}$, vítimas de práticas sociais violentas.

No texto intitulado Gênero, raça e sexualidade: uma proposta de debate interseccional, de Marco José Duarte, Dandara Oliveira e Kesia Ignácio, apresenta-se uma problematização a respeito do conceito de interseccionalidade, amplamente popularizado no ambiente acadêmico. Nesse sentido, o trabalho traz o debate interseccional em cena a partir de escritoras negras que, em diferentes momentos históricos, contribuíram com essa perspectiva. As/os autoras/es apontam, ainda, outras questões, fundamentos e elementos que integram as discussões da interseccionalidade no tempo presente. Assim, articulam gênero, raça e sexualidade objetivando se aprofundar em uma proposta de debate teórico-metodológico interseccional.

Em Bruxas, loucas ou más: aborteiras no entre de feitiços e problemas, oitavo capítulo, María Barone, Alexsandro Rodrigues e Pablo Rocon 
constroem uma narrativa que abarca questões implicadas na temática do aborto na contemporaneidade. Os/as autores/as perpassam os usos e signos das palavras aborto, aborteiras, bruxas e demais variações, reconstruindo e historicizando a opressão sobre mulheres e problematizam a relação entre Estado e as liberdades civis de mulheres. Com isso, expõem a realidade brasileira de abortamentos, evidenciando as fragilidades e o não-acesso às políticas públicas num contexto de (i)legalidades questionáveis.

Em Corpos em transformação: narrativas de mulheres trans e travestis sobre os sentidos de envelhecer, Ana Paola Lima e Danie de Jesus analisam narrativas de mulheres trans e travestis sobre os sentidos de envelhecer. O referencial teórico abarca a perspectiva da noção de discurso, corpo, envelhecimento e poder. Os resultados sugerem que ocorre um processo de envelhecimento precoce dessas mulheres em decorrência de violências físicas e simbólicas. Além disso, a velhice é apresentada como o momento da saturação da beleza e constitui um sinal de perda de valor para o mercado da prostituição. Ademais, as mulheres trans mais idosas podem assumir um papel de conselheiras para as mais jovens em decorrência da experiência acumulada.

Guilherme Passamani, Marcelo Rosa, Jônatas Alaman e Tatiana Lopes, em Prostituição masculina em contextos transnacionais: projetos, campo de possibilidades e agência em Lisboa, abordam o tema da prostituição masculina, tendo Portugal como cenário de pesquisa. Num primeiro momento, a abordagem lança olhares para as experiências desses homens brasileiros em suas cidades de origem, delineando o momento em que a prostituição se torna um projeto. Em seguida, os/as autores/as se debruçam sobre a experiência de prostituição de seus interlocutores/as em Lisboa. De forma minuciosa e se atentando às particularidades no mercado de sexo local, os/as autores/as problematizam as relações de poder e a racialização dos desejos e dos corpos brasileiros, bem como os impactos na subjetividade dos/as sujeitos/as ouvidos/as.

Em O funk carioca e o dom de visibilizar culturas e identidades: quando a representatividade transforma o social (?), décimo primeiro capítulo, Benjamim Neves analisa três produções audiovisuais, a partir de conceitos como transfeminismo das masculinidades e geografia da proximidade humana. $\mathrm{O}$ autor submete o resultado à metodologia comparativa e identifica que o conceito de cultura tem se alterado na contemporaneidade e que o 
funk carioca tem se colocado na vanguarda das mudanças sociais e culturais. Todavia, partindo de concepções de identidade e representatividade, Neves problematiza a invisibilidade das transmasculinidades no mercado das grandes produtoras de funk (mainstream), que classifica como cisbrancoheteronormativo.

Em Bricolagem parental: análise cartográfica fílmica de filiação na configuração familiar singular apresentada em Patrik 1.5, Lorena de Oliveira e Márcio Neman, por meio do posicionamento teórico-metodológico praticado à pesquisa audiovisual denominado cartografia fílmica, sustentado pela pesquisa bibliográfica esquizoanalista proposta por Deleuze e Guattari, propõem uma análise da produção imagética e discursiva apresentada na obra cinematográfica sueca Patrik 1.5, filme que aborda alguns aspectos sócio-histórico-políticos e culturais relacionados à adoção tardia por famílias homoparentais.

Em Manifesta Lésbico-Feminista, de autoria coletiva, se apresenta um texto reivindicação por uma existência plural, diversa e visibilizada. 0 texto produzido é resultante de um processo de formação feminista desenvolvido durante a pandemia de COVID-19.

No último texto, as autoras Sara Wagner York, Bruna Benevides e Megg Rayara Gomes de Oliveira partem do termo de "travestir" enquanto verbo que denota falseação, marginalidade e de algo não genuíno, para um processo de ressignificação política, que fundamenta todo sentido das reivindicações apresentadas no Manifesto Travesti.

Nós, da gestão 2019-2020 da ABEH, convidamos você à leitura dessas obras artísticas e acadêmicas e desejamos que as conexões sejam múltiplas, potentes e construtivas.

Boa Leitura!

Márcio Alessandro Neman do Nascimento

Bruna Andrande Irineu Brendhon Andrade Oliveira Jefferson Adriã Reis 


\section{PARTE I}

\section{A (R) TIVISMOS, \\ MEMÓRIAS E \\ RESISTÊNCIAS}




\title{
20 anos de ABEH: co-produções ativistas, acadêmicas e artísticas
}

\author{
Bruna Andrade Irineu
}

Neste texto, recupero a história da Associação Brasileira de Estudos da Homocultura (ABEH), evidenciando como nesses 20 anos de existência a entidade se articulou a partir da indissociabilidade entre produção acadêmica, ativista e artística. $\mathrm{O}$ argumento é consubstanciado pela análise do histórico de documentos institucionais da associação, como atas, projetos, estatutos e relatos de gestões anteriores, somados a capítulos e artigos publicados por presidentes anteriores e a minha análise como atual presidente, bem como do que nossa gestão produziu neste biênio 2019-2020.

A ABEH foi criada em 13 de junho de 2001, em Niterói, a partir de uma deliberação na Assembleia do "III Encontro de Pesquisadores Universitários - Literatura e Homoerotismo”, promovido pelo Núcleo de Estudos de Língua Portuguesa e Africana (NEPA), da Universidade Federal Fluminense (UFF), sob organização dos professores Mário Cesar Lugarinho e José Carlos Barcellos, os quais foram centrais para a criação da ABEH. Na assembleia, conforme o relato na página virtual do NEPA, havia cerca 60 pesquisadoras e pesquisadores do Brasil e do exterior.

\section{Situando os estudos de diversidade sexual e de gênero a partir da memória da ABEH}

Luma Nogueira Andrade, em capítulo publicado no livro "História do Movimento LGBT no Brasil”, lançado em 2019, sob organização de James Green, Renan Quinalha, Márcio Caetano e Marisa Fernandes, destaca alguns nomes que se somam aos de Lugarinho (UFF na época, hoje USP) e de Barcellos (UFF), nesse início de associação, como: Deneval Azevedo (UFES), 
Wilton Garcia (USP), Emerson da Cruz Inácio (USP), Maria Bernadette Lyra (USP) e Eliane Berutti (UERJ), entre outros. E aponta ainda, as razões que motivaram a fundação da associação:

Um dos fortes embasamentos para a criação da associação foi a existência de eventos como: Olhares entendidos - UCAM; Colóquio Poéticas do Corpo Contemporâneo - GEITES (Grupo de Estudos Interdisciplinares de Transgressão); Encontro da UFOP e Corpo e Cultura - USP. Estas atividades demarcavam a existência de espaços, no campo acadêmico, voltados para discussões e produções de conhecimentos sobre à homocultura. (ANDRADE, 2018, p. 502).

O primeiro presidente eleito da ABEH foi o Prof. Deneval Siqueira de Azevedo Filho (UFES), que coordenava o GEITES (Grupo de Estudos Interdisciplinares de Transgressão). Sua indicação foi feita ainda na assembleia de Niterói e coube à primeira gestão presidir o I Congresso da ABEH, em Vitória - ES, no ano de 2002.

Andrade (2018) recompõe também o cenário de institucionalização da $\mathrm{ABEH}$, em princípio tanto a primeira quanto a segunda gestão discutiram sobre o registro cartorial da associação. Mas é somente na terceira gestão, sediada em Belo Horizonte - MG, que a entidade será formalizada. Como nos alertava Irineu (2019), é preciso situar as temporalidades concernentes ao percurso LGBTI+ no Brasil, destacando por exemplo o fato de que a primeira geração de pesquisadores fundadores da $A B E H$ herdara a experiência do próprio movimento LGBT, que se onguizou na década de 1990 para dar maior capilaridade às suas ações institucionais.

A institucionalização da $\mathrm{ABEH}$ vai garantir um entre-lugar de entidade da sociedade civil, mas ao mesmo tempo vinculada à universidade, o que vai possibilitar ampla circulação da associação na cena nacional, mas não sem tensões habituais envolvendo movimentos sociais e universidade (IRINEU, 2019).

Apesar das tensões [...] entre movimento, universidade e no interior de cada um desses campos, os desenvolvimentos recentes da agenda política nacional, no que diz respeito às demandas de movimentos sociais no âmbito dos direitos para mulheres e para LGBT, parecem, de fato, estimular mudanças significativas nessa relação. Tais desenvolvimentos se fazem acompanhar da colocação em pauta da necessidade de produção de conhecimento, em especial quanto aos direitos de LGBT (área temática em que o volume de produção e a difusão de conhecimento são 
menores e que se constitui a partir de uma rede mais difusa e menos institucionalizada em comparação aos estudos de gênero) (FACCHINI, 2005 e 2009; DANILIAUSKAS, 2011). Demandas por produção e difusão de conhecimento têm marcado presença em documentos de referência para políticas públicas em âmbito nacional, elaborados a partir de processos participativos como as Conferências Nacionais dos Direitos das Mulheres, as Conferências Nacionais de Políticas para LGBT e as Conferências Nacionais de Direitos Humanos (DANILIAUSKAS, 2011). FACCHINI, DANILIAUSKAS e PILON, 2013, p.168).

Deste modo, os congressos e seminários envolvendo temas LGBTI+ - como o próprio congresso da ABEH - passam também a contar com maior apoio financeiro no período de ascensão do governo PT (Partido dos Trabalhadores), a partir dos anos de 2003, bem como com o crescimento da bancada pró-LGBTI no Congresso Nacional, já no final da primeira década deste século. Esse cenário proporcionou maior captação de recursos às entidades de diversidade sexual e de gênero no Brasil, fruto das próprias diretrizes do Programa Brasil sem Homofobia (2004) e do I Plano Nacional de Promoção da Cidadania e Direitos Humanos LGBT (2009).

A ABEH participou ativamente do processo de monitoramento das políticas públicas para população LGBTI+, quando passou a ocupar um assento no Conselho Nacional de Combate a Discriminação LGBT (CNCDLGBT), na primeira gestão iniciada no ano de 2011 e composta também por outras entidades nacionais LGBT, sindicais e profissionais (IRINEU, 2019). A relação da $A B E H$ com as demais entidades esteve entre tensões em diversos momentos, seja pela desconfiança em relação a academia ou mesmo pelas disputas em torno das identidades sexuais, já que as/os representantes da ABEH sempre estiveram atentas à crítica queer (IRINEU, 2019a; ANDRADE, 2018; COLLING, 2013).

Os rumos da política no Brasil pré e pós-impeachment de Dilma Rousseff envolveram: 1) o esgarçamento da conciliação entre setores feministas, LGBT e religiosos, anunciada na Carta ao Povo de Deus ainda nas eleições de 2010; 2) o veto ao Kit Escola sem Homofobia, com posição contrária do governo ao material explicitada publicamente; 3) e, posteriormente, as eleições de Jair Bolsonaro baseada em discursos antigênero, reproduzidos também na sessão do plenário do Congresso Nacional que aprovou o impedimento de Dilma (IRINEU, 2019a; ARAGUSUKU, LARA e MARTINS, 2019). 
A atual diretoria da ABEH inicia seu trabalho no mesmo mês em que Bolsonaro assume a presidência. E em menos de 30 dias, seu governo já exibia amostras de sua política antigênero, entre retrocessos na política de AIDS e de educação para diversidade, bem como em aparições públicas da ministra Damares Alves afirmando que neste governo "meninos vestem azul e meninas vestem rosa" (IRINEU, 2019b). O rompimento com o governo e a recusa combativa de diálogo tornou-se uma exigência coletiva, especialmente ampliada com a extinção dos conselhos de direitos humanos, em junho de 2019, incluindo o próprio Conselho Nacional LGBT. Alternativas coletivas de organização entre as entidades da sociedade civil foram sendo feitas especialmente no âmbito do Conselho Nacional Popular LGBTI+, que foi lançado publicamente em junho de 2020, já durante a pandemia.

Esse percurso político pode ser revisitado a partir das notas públicas com posicionamentos da $A B E H$ e nos relatórios sobre as três reuniões do CNCDLGBT que participamos antes de sua extinção, como demonstra o quadro 1, logo abaixo. Nele, é possível notar como a crítica e resistência à retórica antigênero marcam a Associação nestes dois anos de atuação, especialmente nas notas de janeiro de 2019 e de junho de 2020, onde manifestamos nosso repúdio à política de extermínio do atual governo federal.

Quadro 1 - Lista de Notas e Posicionamentos da ABEH entre 2019 e 2020

\begin{tabular}{|l|c|}
\hline Assunto da Nota & Data \\
\hline Posicionamento da ABEH sobre ofensiva conservadora do governo federal & $01 / 2019$ \\
\hline Nota Pública sobre Dia Internacional das Mulheres & $03 / 2019$ \\
\hline Posicionamento sobre a extinção do Conselho Nacional LGBT & $07 / 2019$ \\
\hline Nota de Pesar pelo Falecimento da Ativista Fernanda Benvenutty & $03 / 2020$ \\
\hline $\begin{array}{l}17 \text { de maio - Posicionamento da ABEH sobre a necropolítica do governo } \\
\text { Bolsonaro }\end{array}$ & $05 / 2020$ \\
\hline Nota de Pesar pelo Falecimento da ativista Agatha Lima & $05 / 2020$ \\
\hline $\begin{array}{l}\text { Posicionamento da ABEH sobre a Portaria 545/2020 do MEC em relação às cotas } \\
\text { no ensino superior }\end{array}$ & $06 / 2020$ \\
\hline Nota de Pesar pelo Falecimento de Thina Rodrigues (CE) e Igor Lima (TO) & $06 / 2020$ \\
\hline
\end{tabular}

Fonte: Sistematização própria 
Assim, ressalta-se que a dinâmica política atual da $A B E H$ é reflexo de seu acúmulo histórico em 20 anos, que se encontra e se conecta com o próprio percurso dos estudos de diversidade sexual e de gênero no Brasil, sobretudo a trajetória dos ativismos e das políticas públicas LGBTI+ que possui mais de 40 anos de história.

Vimos, por exemplo, que a reabertura política e o processo de redemocratização do Brasil foram fundamentais no processo de expansão da produção de conhecimento sobre gênero e sexualidade em uma perspectiva distinta as das ciências 'psi' (IRINEU, 2019a). Iniciou-se, assim, um processo de articulação entre os diversos sujeitos vinculados às lutas por direitos sexuais, que culminará em estratégias para interferir no processo de formulação das demandas por políticas públicas.

As áreas da saúde e da educação tornaram-se o foco dos movimentos feministas e LGBT, o que parecia ser justificável, no caso da primeira, pela referência na epidemia de HIV/AIDS e, no caso da segunda, na possibilidade de atingir as relações de preconceito e discriminação desde o primeiro momento de socialização (FACCHINI, DANILIAUSKAS e PILON, 2013). Essa característica perquiriu parcialmente a $\mathrm{ABEH}$, como notamos quando se observa o Quadro 2, que sistematiza as áreas de conhecimento das presidências da $\mathrm{ABEH}$ em seus 10 biênios.

Quadro 2 - Presidentes(as) da ABEH por área de formação e instituição de ensino que se vincula/vinculava no período

\begin{tabular}{|l|l|l|}
\hline Presidente & Área de Formação & Instituição (no período) \\
\hline Bruna Irineu & Serviço Social & UFMT \\
\hline Luma Nogueira & Educação & UNILAB \\
\hline Anderson Ferrari & Educação & UFJF \\
\hline Fernando Seffner & Educação & UFRGS \\
\hline Leandro Colling & Comunicação Social & UFBA \\
\hline Alípio Souza Filho & Ciências Sociais & UFRN \\
\hline Horácio Costa & Letras e Literatura & USP \\
\hline Bruno Leal & Comunicação Social & UFMG \\
\hline Denílson Lopes & Comunicação Social & UNB \\
\hline Deneval Siqueira & Letras e Literatura & UFES \\
\hline
\end{tabular}

Fonte: Sistematização própria 
Sendo possível notar uma prevalência de pesquisadoras da educação apenas nas últimos gestões, enquanto as primeiras alternam entre as áreas de Letras e de Comunicação Social. Isso foi determinante para a direção teórica e política da $\mathrm{ABEH}$, em especial para sua nomeação, ao carregar o termo homocultura e mesmo para definição de seu Estatuto, que demonstra uma intencionalidade da associação em centrar esforços mais exclusivos na organização do congresso, o que ao longo dos anos foi se modificando, tanto com a entrada da ABEH no Conselho Nacional LGBT, quanto com a criação de um periódico científico.

\section{A ABEH e a coprodução de saberes em defesa da diversidade sexual e de gênero}

A trajetória da $A B E H$ expressa os impasses e as possibilidades vividos no campo dos estudos de diversidade sexual e de gênero. Exemplo disso está nos limites do próprio termo homocultura, que, como salienta Luma Andrade (2018), não representa hoje a pluralidade de estudos e de pesquisadoras/ es que circulam pelos nossos congressos. A ideia de homocultura era um caminho epistemológico possível para a inserção dos estudos gays e lésbicos nas universidades brasileiras no início dos anos 2000, fundamentalmente relacionada com o que propunham os pesquisadores, que também fundaram a ABEH, Rick Santos e Wilton Garcia, no livro "A escrita de Adé: perspectivas teóricas dos estudos gays e lésbicos no Brasil”, e que Andrade (2018, p. 510) destaca, a partir dos dois estudiosos, enquanto o imbricamento dos conceitos de homoerotismo e de cultura com sentido de explicitar a constituição de uma "rede de conversações" que comportasse os argumentos em defesa das minorias sexuais.

Nestes 20 anos, houve tentativas de mudança do nome da entidade e nenhuma delas foi aprovada, tendo tido aprovação apenas o nome do congresso da $\mathrm{ABEH}$, que passou a ser Congresso Internacional de Estudos da Diversidade Sexual e de Gênero, que foi ampliado na gestão anterior a nossa para Diversidade Sexual, Gênero e Raça e na atual para Diversidade Sexual, Étnico-racial e de Gênero. As disputas em torno da gramática de nosso campo teórico são recorrentes, as quais me parecem profundamente inerentes à pluralidade de sujeitos, desejos e experiências que são abarcados em nossos estudos e práticas artivistas. Resultado também do que Facchini, Daniliauskas e Pilon (2013) apontam quando afirmam que as últimas décadas 
trouxeram crescimento da preocupação com questões relacionadas a gênero e a sexualidade, tanto no campo das políticas públicas quanto dos movimentos sociais, com destaque também para o âmbito acadêmico.

Os temas dos nove congressos da ABEH, explicitados no Quadro 3, demonstram a atenção específica do campo de conhecimento em cada momento histórico. Do mesmo modo que sinaliza a concentração de pesquisadores/as na região sudeste, após a expansão universitária temse uma capilarização de eventos para outras regiões, mas que ainda não garantiu à $A B E H$ ser sediada na região norte, por exemplo.

\section{Quadro 3 - Temas dos Congressos da ABEH por ano e cidade onde ocorreu o evento}

\begin{tabular}{|c|c|l|}
\hline Ano & Cidade & \multicolumn{1}{c|}{ Tema do Congresso } \\
\hline 2018 & Fortaleza & $\begin{array}{l}\text { IX CINABEH - Diversidade Sexual, Gênero e Raça - Diálogos } \\
\text { Brasil - África }\end{array}$ \\
\hline 2016 & Juiz de Fora & $\begin{array}{l}\text { VIII CINABEH - ABEH e a construção de um campo de Pesquisa } \\
\text { e Conhecimento: desafios e potencialidades de nos (re) } \\
\text { inventarmos }\end{array}$ \\
\hline 2014 & Rio Grande & $\begin{array}{l}\text { VII CINABEH - Estudos sobre a Diversidade Sexual e de } \\
\text { Gênero: Práticas, Pedagogias e Políticas Públicas }\end{array}$ \\
\hline 2012 & Salvador & VI CINABEH - Memórias, rumos e perspectivas \\
\hline 2010 & Natal & V Congresso da ABEH - "Desejos, Controles e Identidades" \\
\hline 2008 & São Paulo & $\begin{array}{l}\text { IV Congresso da ABEH - "Retratos do Brasil Homossexual: } \\
\text { fronteiras, subjetividades e desejos" }\end{array}$ \\
\hline 2006 & $\begin{array}{c}\text { Belo } \\
\text { Horizonte }\end{array}$ & $\begin{array}{l}\text { III Congresso da ABEH - "Discursos da diversidade sexual: } \\
\text { lugares, saberes, linguagens" }\end{array}$ \\
\hline 2004 & Brasília & II Congresso da ABEH - “Imagem e diversidade sexual” \\
\hline 2002 & Vitória & I Congresso da ABEH - "Homocultura e Cidadania”, \\
\hline
\end{tabular}

Fonte: Sistematização própria

Os esforços acadêmicos estão sempre articulados com a necessidade de responder as urgências da realidade social, o que irá promover investimentos teórico-políticos a cada tentativa de resposta a essas demandas e, ao mesmo tempo, também indicará os limites das próprias respostas, posto que a vida é dialética e por conseguinte o conhecimento sempre será temporário, parcial e provisório (IRINEU, 2019a).

Nesta trajetória, João Bosco Hora Góis (2003), pesquisador que também participou dos encontros de fundação da $\mathrm{ABEH}$, em texto do início dos anos 
2000, convocava os estudos de sexualidades a uma certa autonomia do debate de gênero, mesmo destacando que as reflexões feministas foram fundamentais para o desenvolvimento dos mesmos estudos. Ele apontou que a forma como estes permaneceram, tão vinculados aos debates de gênero, obstruiu uma possível autonomia das análises no campo das sexualidades que conseguisse captar as particularidades socioculturais que permeiam o universo homossexual brasileiro.

A proposta de Góis (2003) e de outros pesquisadores que comungavam de sua posição já vinha sendo implementada em outros países, como os Estados Unidos, onde já havia essa tensão entre estudos feministas e outro campo mais dedicado a pensar as homossexualidades - que foram os chamados estudos Gays e Lésbicos. No Brasil, essa movimentação também se iniciou nos anos de 1980, a partir das pesquisas de Peter Fry, Edward MacRae, Michel Misse e Carmem Dora Guimarães, que desafiaram uma conjuntura política autoritária que dificultava a realização de pesquisas nas universidades brasileiras (IRINEU, 2019a). Há uma controvérsia sobre o enfoque dos trabalhos no campo dos estudos gays e lésbicos, cuja crítica vem sendo feita por pesquisadoras(es) dos estudos queer (COLLING, 2013), feminismo lésbico e transfeminismos (IRINEU, 2019; JESUS, 2018).

A emergência de estudos sobre travestilidades e transexualidades que se iniciam timidamente nos anos de 1980, mas se ampliam fortemente após os anos 2000, vão evidenciar também uma geração de novas pesquisadoras LGBTI+ ocupando não mais o espaço de interlocução, mas sim produzindo sobre a própria comunidade. Quanto aos estudos sobre lesbianidades, assevero que é uma produção que tem tido um aumento recente potencializado pela entrada de LGBTI+ na docência de nível superior, criação de espaços específicos em periódicos e pequenas editoras, isso já após os anos de 2010. Outro fator está em militantes lésbicas buscarem as pós-graduações nas universidades para recontar suas histórias de luta a partir da pesquisa. A bissexualidade ainda aparece de maneira incipiente em nosso campo de estudos, sendo urgente a atenção para o tema.

Esse contexto nos fez acreditar que o investimento em espaços de difusão do conhecimento pode somar na visibilidade de jovens pesquisadoras(es) atentas(os) a temas urgentes. $O$ que nos levou ainda na gestão presidida por Luma Nogueira, no ano de 2018, a criar a REBEH - Revista Brasileira de Estudos da Homocultura. A REBEH publicou até o momento 10 números $\mathrm{e}$ 
levantando essas produções podemos observar uma prevalência de estudos que corroboram com a concepção de interseccionalidade, operando com outros marcadores sociais da diferença além de gênero e sexualidade, como raça, geração e classe social. E uma profunda compreensão da indissociabilidade entre produção acadêmica e artística, bem como da notória coprodução de conhecimento entre academia e ativismo ( $\mathrm{COACCl}$, 2018).

Quadro 4 - Quantitativo de publicações por seção na REBEH (Números 1 a 10)

\begin{tabular}{|l|c|}
\hline \multicolumn{1}{|c|}{ Seção na REBEH } & Quantitativo Publicado \\
\hline Artigos de Tema Livre & 25 \\
\hline Dossiês Temáticos & 7 \\
\hline Artigos em Dossiê Temático & 76 \\
\hline Entrevistas & 8 \\
\hline Relatos de Experiência & 10 \\
\hline Ensaios & 13 \\
\hline Tessituras Artísticas & 6 \\
\hline Resenhas & 12 \\
\hline Homenagem de Vida & 2 \\
\hline Documentos & 27 \\
\hline
\end{tabular}

Fonte: Sistematização própria

O Quadro 4 explicita o quantitativo de textos publicados nos 10 números da REBEH entre os anos de 2018 e o primeiro semestre de 2021. Ao observarmos esses textos, é possível identificar que os temas de diversidade sexual e de gênero se espraiaram para os distintos níveis de formação e na atualidade circulam com maior distribuição geográfica do que no início dos anos 2000. A flexibilidade no perfil da autoria, podendo as/os ativistas não vinculadas(os) às universidades também publicarem na maioria das seções, também indica a horizontalidade do processo editorial da revista, que é influenciado pela própria história da $\mathrm{ABEH}$.

Os Quadros 5 e 6 ilustram os temas dos dossiês temáticos especiais publicados e previstos para publicação na REBEH. Temas como: saúde mental, formas expressivas (que reuniu artigos sobre música e dança), invisibilidade lésbica e autoetnografia demonstram a atenção aos debates 
atuais e às lacunas históricas no campo de estudos da diversidade sexual e de gênero.

Quadro 5 - Dossiês Temáticos Especiais publicados na REBEH por Tema

\begin{tabular}{|l|}
\hline Movimentos sociais e ativismos LGBTI e Feministas \\
\hline Saúde mental, gêneros e sexualidade: perspectivas interseccionais \\
\hline Corpos em movimento: políticas, experiências e métodos possíveis \\
\hline Sujeitos em performance: diversidade, diferença e formas expressivas \\
\hline (R)existência e invisibilidade lésbica: entre conceitos, panoramas e percursos \\
\hline Torna-nos criança: auto/etnografias, cuidados e reparações \\
\hline Teoria Social Crítica e LGBTI+ \\
\hline
\end{tabular}

Fonte: Sistematização própria

\section{Quadro 6 - Dossiês Temáticos Especiais previstos na REBEH por Tema}

Políticas de extermínio de grupos sociais: transfobia, homofobia e feminicídio

Reflexões em torno da saúde: cruzando temas, problemas e perspectivas

Interseccionalizando em educação, lutas sociais e direito à diferença

Participação política LGBTI+ no Brasil: passado, presente e projetos de futuro

Fonte: Sistematização própria

A REBEH tem passado por profundas mudanças estéticas e operacionais, desde a migração do portal da UNILAB para o portal da UFMT, criação de novo layout do template, alteração da versão do Open Journal Systems (OJS) e a recente aquisição de D.O.I. O amadurecimento editorial da revista também dependerá de as futuras gestões manterem aceso o compromisso com a socialização e a difusão do conhecimento coproduzido entre universidade, artistas e movimentos sociais. Tarefa que se torna ainda mais desafiadora em um contexto de corte ao financiamento das políticas de educação e de ciência e tecnologia.

\section{No meio do caminho havia o governo Bolsonaro e a pandemia de COVID-19}

Como apontei anteriormente, a posição da $A B E H$ quanto ao governo Bolsonaro foi explicitada desde a nossa primeira nota pública. Entretanto, 
cabe destacar que o agravamento da política genocida deste presidente se aprofundou com a pandemia de COVID-19.

A ABEH realizaria seu décimo congresso em novembro deste ano de 2020. Nos articulamos para aprovar recursos de emenda parlamentar e para pleitear apoio da CAPES, CNPq e FAPEMAT. À exceção da emenda, nossos pleitos foram sendo inviabilizados pelos cortes no MEC e nos órgãos de fomento à pesquisa, de modo que intencionávamos realizar um congresso pé no chão, distante da última edição que pôde contar com uma boa captação de recursos. Programou-se para novembro de 2020 e prestes a pôr o website do evento no ar, a pandemia e o isolamento social modificaram brutalmente nossos planos.

Com intuito de mobilizar filiados/as fizemos um recredenciamento de dados, reconstruímos o website da $\mathrm{ABEH}$ e criamos o perfil nas redes sociais Instagram, Twitter e Youtube, já que só havia o Facebook. Como estratégia de divulgação da entidade e de popularização do conhecimento, investimos na ação $A B E H$ Debate, que se constituiu em Live no Instagram todas as segundas-feiras, às 19 horas. O Quadro 7 mostra que foram 19 conversas entre pesquisadoras(es) e 2 saraus, que envolveram o aniversário de 19 anos da $\mathrm{ABEH}$ e um manifesto no dia da visibilidade lésbica, pauta que tomei como responsabilidade desta gestão, já que me tornei a primeira presidente lésbica da associação.

\section{Quadro 7 - Live no Instagram por tema e pesquisadoras(es)}

\begin{tabular}{|l|l|}
\hline \multicolumn{1}{|c|}{ Tema da Live } & \multicolumn{1}{|c|}{ Pesquisadoras(es) } \\
\hline Ciência, Fervo e Luta - 19 anos da ABEH & $\begin{array}{l}\text { Diretoria da ABEH, Conselheiras e Artivistas } \\
\text { Convidadas }\end{array}$ \\
\hline $\begin{array}{l}\text { Os usos da ideologia do gênero pelo } \\
\text { bolsonarismo }\end{array}$ & Tatiana Lionço (UnB) e Bruna Irineu (UFMT) \\
\hline $\begin{array}{l}\text { Transmasculinidades e envelhecimento } \\
\text { no Brasil }\end{array}$ & Benjamin Neves (UFMT) e Marcos Silva (UFMT) \\
\hline $\begin{array}{l}\text { Política de saúde LGBT e formação dos } \\
\text { profissionais de saúde }\end{array}$ & Pablo Rocon (UFMT) e Marco Duarte (UFJF) \\
\hline $\begin{array}{l}\text { Rotas de fuga à heteronorma entre } \\
\text { mulheres na prisão }\end{array}$ & Simone Brandão (UFRB) e Bruna Irineu (UFMT) \\
\hline $\begin{array}{l}\text { Colonialidade, Bio-Necropolítica e a } \\
\text { COVID-19 }\end{array}$ & Fátima Lima (UFRJ) e Bruna Irineu (UFMT) \\
\hline
\end{tabular}




\begin{tabular}{|c|c|}
\hline $\begin{array}{l}\text { Os isolados da sociedade antes do } \\
\text { confinamento pela COVID-19 }\end{array}$ & $\begin{array}{l}\text { Jaqueline de Jesus (IFRJ) e Márcio Neman } \\
\text { (UFR) }\end{array}$ \\
\hline $\begin{array}{l}\text { Dissidências sexuais e de gênero fora dos } \\
\text { grandes centros }\end{array}$ & $\begin{array}{l}\text { Guilherme Passamani (UFMS) e Moises Lopes } \\
\text { (UFMT) }\end{array}$ \\
\hline $\begin{array}{l}\text { Lusotransfonia: travestis e transexuais } \\
\text { em Portugal }\end{array}$ & Luma Andrade (UNILAB) e Bruna Irineu (UFMT) \\
\hline Pornografia gay e virilidade & $\begin{array}{l}\text { Gabriel Oliveira (IFMT) e Guilherme Passamani } \\
\text { (UFMS) }\end{array}$ \\
\hline História do Movimento LGBT no Brasil & $\begin{array}{l}\text { Renan Quinalha (UNIFESP) e Bruna Irineu } \\
\text { (UFMT) }\end{array}$ \\
\hline $\begin{array}{l}\text { Festa é política: Marchas, Paradas e } \\
\text { Mobilizações LGBT }\end{array}$ & $\begin{array}{l}\text { Marcos Silva (UFMT) e Regina Facchini } \\
\text { (UNICAMP) }\end{array}$ \\
\hline Literatura LGBTI & $\begin{array}{l}\text { Jaqueline de Jesus (IFRJ) e Amara Moira } \\
\text { (UNICAMP) }\end{array}$ \\
\hline $\begin{array}{l}\text { Estado, nacionalismos e diversidade } \\
\text { sexual e de gênero }\end{array}$ & Fabiano Gontijo (UFPA) e Moisés Lopes (UFMT) \\
\hline Transexualidade e Candomblé & Kaio Lemos (UFC) e Marco Duarte (UFJF) \\
\hline $\begin{array}{l}\text { O entre-lugar sob o arco-íris: diálogo } \\
\text { sobre raça e sexualidade }\end{array}$ & $\begin{array}{l}\text { Rodrigo Reduzino (UNICAMP) e Ana Cristina } \\
\text { Santos (UFAL) }\end{array}$ \\
\hline $\begin{array}{l}\text { Política LGBT na educação, ideologia de } \\
\text { gênero e avanço conservador }\end{array}$ & $\begin{array}{l}\text { Alexandre Bortolini (USP) e Tatiana Lionço } \\
\text { (UNB) }\end{array}$ \\
\hline Transvia(da)gens na/da educação & Sara Wagner York (UERJ) e Danie Jesus (UFMT) \\
\hline $\begin{array}{l}\text { Resistências lésbicas na universidde e } \\
\text { blasfêmia na era neoliberal }\end{array}$ & Suely Messeder (UNEB) e Bruna Irineu (UFMT) \\
\hline Feminismo Lésbico e Interseccionalidade & Ana Carla Lemos (UFPE) e Bruna Irineu (UFMT) \\
\hline Manifesto por uma educação sapatão & $\begin{array}{l}\text { Marcela Amaral (UFG), Fran Scoptec (UFMA), } \\
\text { Luciene Neves (UNEMAT), Val Peixoto (UNB), } \\
\text { Fatima Lima (UnB) e Bruna Irineu (UFMT) }\end{array}$ \\
\hline
\end{tabular}

Fonte: Sistematização própria

Depois somamos a isso mais duas webinar no Youtube, em parceria com o podcast Larvas Incendiadas, como demonstra as figuras 1 e 2 , que reuniram debates com maior necessidade de tempo para discussão que a live no instagram permitia. Todas essas conversas estão gravadas nas redes sociais da ABEH para amplo acesso e divulgação, sendo isso um importante fator de visibilidade para a entidade e sua memória. 
Figuras 1 e 2 - Arte de divulgação dos webnários no Youtube em parceria com podcast Larvas Incendiadas
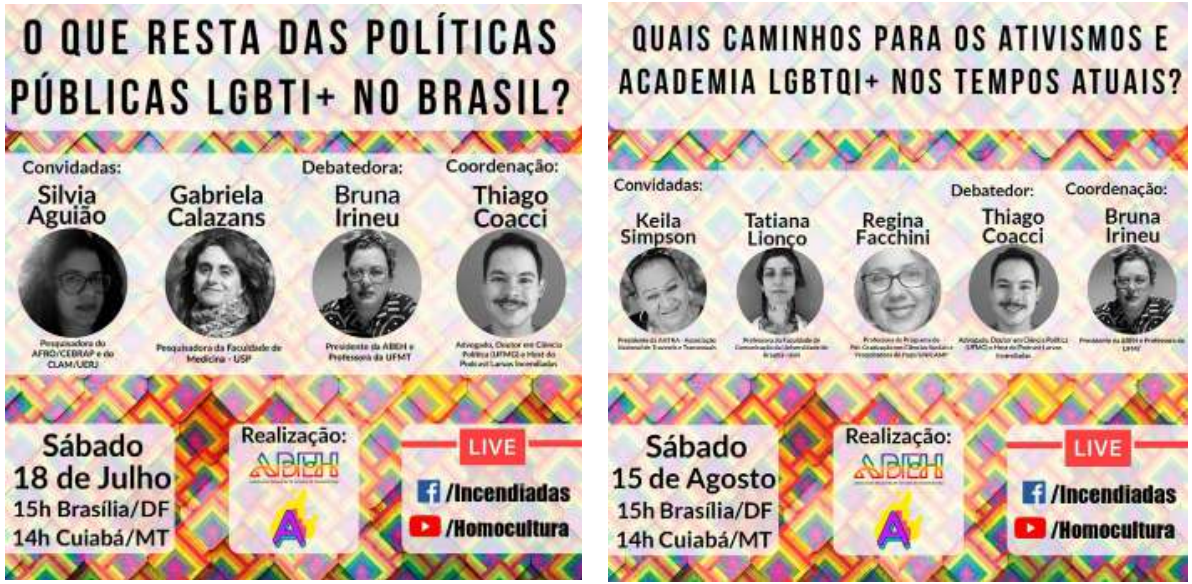

Fonte: Website e Instagram da ABEH

A ABEH também apoiou dois festivais virtuais, como mostram as Figuras 3 e 4, durante a pandemia: o Marsha Pride, realizado pelo Coletivo Marsha em parceria com a Mídia Ninja, Fervo 2k20, entre outras entidades; e o festival da Semana do Orgulho e Resistência LGBTQI+, organizado pelo Conselho Nacional Popular LGBTI. Ambos envolveram apresentações artísticas culturais musicais, dança, teatro, poesia e performances audiovisuais diversas.

Figuras 3 e 4 - Arte de divulgação dos Festivais virtuais apoiados pela ABEH em 2020
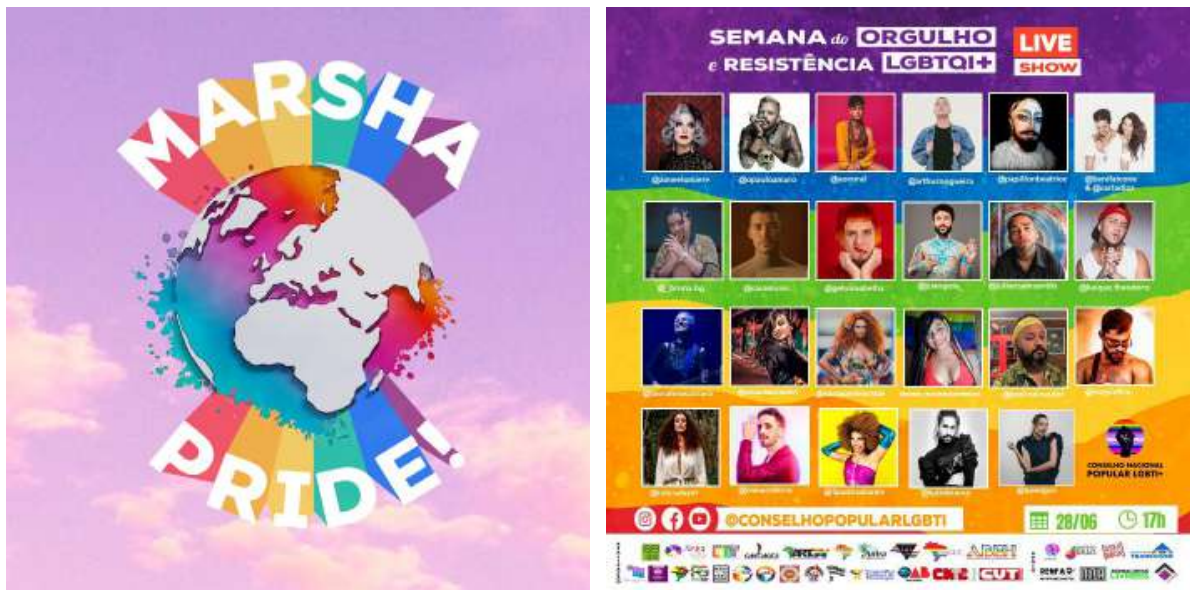

Fonte: Instagram e Twitter da ABEH 
Durante esse período representei a ABEH em inúmeras webinar e Lives, bem como em reuniões locais e nacionais. $O$ contexto pandêmico ampliou a agenda de trabalho de pesquisadoras(es) docentes mundo afora e tende a perdurar este cenário de trabalho e ensino remoto enquanto não houver vacinação total da população. Considerando isso, nossa gestão entendeu que o décimo congresso deverá ser virtual, centrando-se no debate sobre a produção de resistências e políticas de vida.

Assim, prorrogamos a gestão para realizar o congresso no primeiro quadrimestre do ano de 2021, em uma experiência virtual distante de como gostaríamos. $\mathrm{O}$ encontro presencial da $\mathrm{ABEH}$ e tantos outros eventos acadêmicos que nos dão o fôlego do afeto e da troca mútua precisarão ser adiados. Em respeito à urgência de nos cuidarmos e de cuidarmos da natureza, em um momento em que perdemos tantas vidas e vemos a destruição de nossos biomas, barbárie esta que se intensifica em um governo ultraliberal e neoconservador (IRINEU, 2020).

Como nos ensina Ailton Krenak (2020), o amanhã não está à venda e pode ser que não haja depois. No capitalismo não há espaço para justiça, para o bem-viver e tampouco para liberdade, pois nele tudo está à venda, inclusive a nossa própria existência, especialmente as vidas negras, de mulheres, LGBTI+, idosos e pobres. Nossa gestão na $A B E H$ não tem se furtado em se somar às vozes que denunciam o genocídio, mas que também potencializam e coproduzem resistências. 


\section{REFERÊNCIAS}

ANDRADE, Luma Nogueira. ABEH: uma história de resistência e de produção do conhecimento. In: GREEN, James N.; QUINALHA, Renan; CAETANO, Márcio; FERNANDES, Mariza (Orgs.). História do Movimento LGBT no Brasil. São Paulo: Alameda, 2018. pp. 501-514.

ARAGUSUKU, Henrique; LARA, Maria Fernanda Aguillar; FRACAROLLI, Yuri; MARTINS, Alexandre Nogueira. Estado, Políticas Sexuais e Cidadania LGBT no Brasil Pós-Impeachment. REBEH

- Revista Brasileira de Estudos da Homocultura, V. 02, N. 08, Out.-Dez., 2019. pp. 05-33. Disponível em <https://periodicoscientificos.ufmt.br/ojs/index.php/rebeh/article/view/9203>.

CASSAL, Luan Carpes. Um estudo entre ruínas: o Programa Rio Sem Homofobia e a política LGBTI fluminense. REBEH - Revista Brasileira de Estudos da Homocultura, V. 01, N.04, Out.-Dez., 2018. pp. Disponível em < https://periodicoscientificos.ufmt.br/ojs/index.php/ rebeh/article/view/9203>.

COACCI, Thiago. Conhecimento Precário e Conhecimento Contra-público: a coprodução dos conhecimentos e dos movimentos sociais de pessoas trans no Brasil. Tese de Doutorado. Belo Horizonte: Universidade Federal de Minas Gerais. Faculdade de Filosofia e Ciências Humanas. 2018.

COLLING, Leandro. A igualdade não faz o meu gênero - Em defesa das políticas das diferenças para o respeito à diversidade sexual e de gênero no Brasil. Contemporânea, v.3, n²2, jul./ dez., 2013, p.405-427.

FACCHINI, Regina; DANILIAUSKAS, Marcelo; PILLON, Ana Claudia. Políticas sexuais e produção de conhecimento no Brasil: situando estudos sobre sexualidade e suas conexões. Revista de Ciências Sociais. Fortaleza, v. 44, nº 1, jan./jun., 2013, p.161-193.

GÓIS, João Bosco Hora. Desencontros: as relações entre os estudos sobre a homossexualidade e os estudos de gênero no Brasil. Revista de Estudos Feministas, Florianópolis, v.11, ano1, p. 321-336, jan-jun/2003.

IRINEU, Bruna Andrade. Neoliberalismo, Desdemocratização e Cruzada Antigênero? A política das ruas enquanto caminho de resistência. In: IGNACIO, Taynah et al. Tem saída? Perspectivas LGBTI+ sobre o Brasil. Porto Alegre: Zouk, 2020.

IRINEU, Bruna Andrade. Nas tramas da política pública LGBT: um estudo crítico da experiência brasileira (2003-2015). EdUFMT: Cuiabá, 2019a.

IRINEU, Bruna Andrade. "Boys wear blue and girls wear pink": the LGBTI agenda in the face of an extreme right-wing offensive in Brazil. In: MENDOS, Lucas Ramón. State-sponsored homophobia. ILGA: Geneva, 2019b.

JESUS, Jaqueline Gomes. Feminismos contemporâneos e interseccionalidade 2.0: Uma contextualização a partir do pensamento transfeminista. REBEH - Revista Brasileira de Estudos da Homocultura, V. 01, N. 01, Jan.-Mar., 2018. pp. 05-24. Disponível em: <http:// revistas.unilab.edu.br/index.php/rebeh/article/view/87>. 
KRENAK, Ailton. O amanhã não está a venda. Companhia das Letras: São Paulo, 2020.

VENCEREMOS, Ruth; ALVES, Leonardo Nogueira; AMARAL, Ayrton Senna S.; IRINEU, Bruna A. Arte Drag e Resistência LGBTI: entrevista com Ruth Venceremos. REBEH - Revista Brasileira de Estudos da Homocultura, V. 03, N. 10, Abr.-Jun., 2020. pp. 370-377. Disponível em: <https://periodicoscientificos.ufmt.br/ojs/index.php/rebeh/article/view/11607>. 


\title{
Poema: As coisas
}

\author{
Abayomi Jamila
}

as coisas poderiam ser mais simples, né? poderiam ser menos a solidão de descobrir quem se é... poderiam ser menos a dor de aceitar quem se é... as coisas poderiam ser mais simples, né? tipo a primeira vez que a minha saliva molhou sua boca seca debaixo daquele ipê amarelo na Amazonas com a Dom Pedro II tipo quando eu sou a luz negra da sua pele escura numa noite quente de agosto tipo a gente lá em casa, quando você encosta a cabeça no meu peito e olha a poeira do cerrado as coisas poderiam ser mais simples, né? poderiam ser menos as questões "por que me olham assim?" ou "por que me rejeitam?" poderiam ser menos as imposições que nos arrastam para fora da existência poderiam ser menos a divisão do mundo entre nós e eles as coisas poderiam ser mais simples, né? tipo quando a gente escuta Mart'nália, Ellen Oléria e Queen Latifah, tipo quando eu leio Tatiana Nascimento, tipo quando eu te falo de June Jordan... as coisas poderiam ser mais simples, né? tipo quando a gente se olha no espelho e não deseja por nenhum segundo ser alguém diferente as coisas poderiam ser diferentes, né? poderiam? não, poderiam? 


\title{
Poemas: Dicotomia/Amor Proibido/Resquícios
}

\author{
Dani Lebinski
}

\section{Dicotomia}

Queria poder expressar meus sentimentos,

Compor uma música, Com toda a alegria e o sofrimento, Mas estou confusa Haveria solos e corais-dicotomia Haveria violinos e guitarras Ai meu Deus que agonia Sabiás, rouxinóis, mandorovás e cigarras

Que complexa canção ela seria Causaria a muitos, muito estranhamento Passado e futuro no presente estaria Estaria, estaria, seu nome no refrão 


\section{Amor proibido}

Tudo conspira contra nós

Estamos de mãos atadas

Logo meu bem, seremos separadas.

Mas por enquanto podemos estar a sós

E cada segundo com você me enche de esperança

Como se tudo fosse eterno,

Mas condenaram nosso amor ao inferno.

E uma hora a pressão nos alcança.

Ninguém entende o que acontece,

Talvez por não soubermos explicar Como pessoas do mesmo sexo podem se amar Talvez um dia alguém entende e esclarece

Eu não sei o que fazer Mas com você me sinto no céu O seu sal na minha boca é mel

É tudo o que consigo dizer.

Prefiro me calar e ouvir sua voz

Mesmo que tuas palavras não digam nada

Porque por elas me sinto amada

Sem elas me sinto um pó

Porque por você meu coração balança

Com você tudo se torna tão terno

Tudo fica tão eterno Meu sangue pula, pulsa e dança,

E quando o sol anoitece

Bate a vontade de te amar Junto com a agonia de saber que uma hora vai parar

E então minha mente enegrece

Mas eu sou apenas um ser

Em meio à multidão cheia de fel

Que julga que condena e só tem troféus

Que só por debaixo dos panos pode viver 


\section{Resquícios}

Eu uso os mesmos discursos que ela me deixou

Para tratar você mal, como ela me tratou.

Se você gosta ou não gosta, eu já não sei.

Mas não foi enganada eu bem que te avisei.

Já não sei bem mais quem eu sou,

Não estou nem bem nem mal, apenas estou;

Em um mundo inventado para deter o sofrimento.

Esse mundo apenas não me livra do tormento,

De lembrar daquilo tudo que já passou,

De lembrar das mentiras que o amor inventou,

Por isso, me torno às vezes rude.

Não quero justificar minha atitude, Mas pelo medo, a raiva me tomou.

E o passado assim me tornou,

Uma pessoa que finge não sentir Às vezes muito sincera, porque dói o mentir. 


\title{
Micronarrativa: A coleira do Cão
}

\author{
Francis de Lima Aguiar
}

Parecia um cachorro disciplinado, porque vivia em coleira e corrente.

Mas a coleira do cão também eram contos ferozes, caninos à mostra.

Então colocaram sua coleira atrelada a um arame, enorme para as pessoas, uma régua para ele, cachorro.

Sim, ele podia correr, mas tinha que correr e voltar, voltar e correr, correr e correr, correr e ficar ou perder-se correndo quase sem lado, queria ser sem arame.

Durante a semana tinha sempre osso duro de roer, ficava ao alcance da boca, sem limite de arame. Doía roer, mas que jeito? O sábado, às vezes lhe garantia uma carne rija, carne cheia de veias e aquilo era bom. Mas ficava muito na ponta do arame, quando o cachorro já tinha de se esticar demais e estava cansado.

De uma mordida, escorregava pelo arame para debaixo da árvore, cheia de ossos e folhas verdes na copa e amareladas no seu chão. 


\title{
Poema: Do cotidiano na mesa \\ Conto: Quando a macumba pega na gente
}

\author{
Joe Sales
}

\section{Do cotidiano na mesa}

\author{
mãe, \\ bota mais água no feijão \\ que meu namorado vem the conhecer \\ o silêncio se expande \\ a mãe atrapalhada \\ erra no sal
}




\section{Quando a macumba pega na gente}

Dizem que quando a macumba pega na gente, tudo anda pra trás. Brigas constantes, objetos que de maneira inesperada se quebram, pessoas que deixam de nos amar, coisas horríveis - dizem. Na igreja falavam que, em quem com Deus andasse, isso não pegava. Não tinha nada que temer a farofa de Exu na encruzilhada e nem as frutas e a champanhe posta à Pombogira. A Cleide foi criada dentro da igreja. Não saía da igreja. Fosse a hora que perguntassem lá estava ela em oração, em jejum, em comunhão com Deus e seu pastor. Ela trabalhava na costura e era moça solteira, encalhada. Tinha medo de feitiço e de macumba. Apesar de viver falando com Cristo, já tinha testemunhado um caso de marido que largou a esposa por conta da Pombogira. E advinha? O homem não foi ficar com outra mulher, foi é com outro macho se enrabichar. Acredita? A mulher ficava aterrorizada e pedia sempre ao pastor para pôr a bênção em sua vida e em sua casa. Deus me livre ser convencida pelo Diabo a ficar com outra mulher. Misericórdia, Senhor! - exclamava. E à noite, em sonho, seu pensamento vivia metido na irmã mais nova do círculo de oração. E se fosse macumba? Dizem que a Pombogira vira a cabeça de todo mundo. É Diabo de saia. Cleide jejuava todos os dias pedindo perdão. Misericórdia! Misericórdia! E nunca contou pro pastor de seus sonhos. Nem falou da médium que bateu em sua porta pedindo oração. Com receio de que fosse uma cilada, quase deixou passar a missão. Mas aceitou. Até hoje, Cleide e Vera estão juntas na macumba. Quando a macumba pega, não há mal que resista. 0 amor ganha raiz e dá flor. 


\title{
Conto: Tubaína
}

\author{
Jefferson Adriã Reis
}

Nas tardes de quinta-feira nos encontrávamos no quartel para fazer a marcha da guarda mirim. O Cabo ia na frente, gritando os comandos, e nós, organizados dos menores para os maiores, marchávamos atrás. Alguns meninos batiam o pé com força no chão para fazer a poeira vermelha subir. Eu achava aquilo muito idiota porque o Cabo estava sempre nos fazendo limpar e engraxar os coturnos. Mas mesmo no asfalto da única avenida pavimentada da cidade, a terra vinha e tomava conta. Tudo era verde e vermelho. Eu suava naquela farda, mas adorava usar a boina. As pessoas nos olhavam com respeito e mesmo que eu fosse um dos garotos mais novos, me sentia um pouco importante.

Naquela tarde, como de costume, descemos a avenida até a ponte de madeira que cortava a cidade e subimos em direção à praça. Marchamos e marchamos e no retorno, de volta à ponte, tentei espiar para ver se enxergava alguma capivara no córgo, mas não podia girar muito a cabeça senão o Cabo percebia e ralhava. Eu tinha mania de desenhar e tentava reproduzir qualquer coisa que achasse interessante. E na minha cabeça, aquela imagem da ponte, das palafitas e das capivaras era mesmo muito bonita e importante.

No quartel, depois que o Cabo nos dispensou, alguns meninos combinaram de tomar tubaína num bar que ficava no esquinão, que era uma avenida menor que saía da avenida maior. Era no esquinão onde ficava a maioria dos bares, sorveterias e lanchonetes. Quem tinha dado a ideia era o Bruno. Eu tinha notado que o Bruno era um menino diferente dos outros logo nos meus primeiros dias na guarda mirim. Ele era calmo e falava com a gente com atenção. Eu achava isso curioso porque todos gritavam, o Cabo gritava com todo mundo, os meninos mais velhos gritavam com os mais novos, mas o Bruno era muito educado e prestativo e mesmo assim era confiante e sempre conseguia o que queria. Eu já tinha feito alguns desenhos do Bruno, porque ele era a coisa mais legal da guarda mirim. Os outros meninos também gostavam dele e até os rapazes mais velhos o respeitavam. E toda vez que alguém me bulinava perto do Bruno, ele me defendia. 
Quando os meninos começaram a sair para o esquinão, eu os segui, mesmo sem ser convidado, porque o Bruno era quem tinha pensado naquilo, então imaginei que seria legal. Eu geralmente evitava os meninos quando eles se juntavam longe do Cabo, porque nessas horas eles ficavam mais maus e implicavam com os mais novos, nos chamavam de criança e perguntavam se já tínhamos virado homem, se tínhamos pelo no saco e se queríamos uma mudinha. Eles ficavam o tempo todo com essa coisa de mudinha, que era tirar um pelo do saco e dar para outro menino plantar no próprio saco. Eles ficavam comparando um monte de coisas. Eu só tinha alguns poucos pelos e sentia vergonha, então ficava longe de tudo isso. Mas naquela tarde eu quis ir tomar tubaína porque o Bruno estava risonho e brincalhão e eu queria ficar ouvindo as coisas que ele falava e olhando o jeito que ele falava. Então dois dos meninos mais novos e eu fomos atrás do grupo, até que alguém perguntou:

- Cês têm dinheiro pra ajudar a pagar a tubaína?

Eu tinha umas moedas no bolso e mostrei para ele. O problema foi que eles começaram a montar nas suas bicicletas e eu estava a pé. Até os outros meninos mais novos tinham bicicletas e fui ficando para trás. Me deu um aperto no peito. A tarde estava quente e minha garganta seca ficou apertada de dó de mim mesmo. Os meninos iam todos para o esquinão para conversar e rir e eu só chegaria quando a tubaína tivesse acabado. Estava pensando em desistir e ir logo para casa até ouvir o Bruno gritar:

- Chegua aqui, piá, corre!

Ele estava me oferecendo uma carona, então eu me apressei e me sentei no cano da bike. Gostei ainda mais do Bruno naquele momento. Ele era muito gente boa mesmo e eu queria ser igual a ele. Fomos indo pelo centro, as lojas estavam começando a fechar, as vendedoras ocupadas guardando coisas, o único taxista da cidade fumando debaixo das árvores plantadas no meio da avenida, umas mulheres saindo do mercado Aurora com sacolas, garotos e garotas deixando a escolinha de datilografia com suas pastas. Aquele vento quente batendo na cara era gostoso. Fechei os olhos e fiquei sentindo o Bruno ziguezaguear com a bicicleta. Às vezes os braços dele encostavam em mim.

Num instante a gente estava no bar, um dos poucos abertos naquela hora. Os meninos tinham escolhido justamente aquele que dava para a Rua das Véia, quase no fim da avenida. A Rua das Véia era famosa, todo mundo 
falava nessa Rua das Véia e um monte de coisas acontecia lá. Mulher que foi atrás do marido, acerto de contas, briga e até morte. Não à toa a polícia estava sempre lá. Eu tinha uma vontade e um medo de ir nessa rua. Já havia passado lá algumas vezes quando estava indo para a catequese, só que de manhã, e a coisa toda acontecia de noite.

Fiquei olhando para a Rua das Véia, que parecia uma rua comum naquela hora, e os meninos juntaram duas mesas. Arrastamos as cadeiras e o Bruno e outros dois foram lá buscar duas garrafonas de tubaína e os copos. Um deles tentou comprar uma cerveja, mas o homem do bar não quis vender e alguns garotos tiraram sarro da cara do coitado do menino, mas ele riu também e então percebi que estava tudo bem.

Logo estava todo mundo sentado e servido. Tomei a tubaína, gelada, doce. Por algum motivo os meninos da minha idade tinham se sentado à minha esquerda e o Bruno abriu espaço e se sentou à direita. Achei isso muito bom porque talvez fosse um sinal de que estávamos virando amigos e se eu fosse amigo do Bruno os outros meninos iriam gostar de mim também.

Um menino perguntou para o Bruno:

- Você trouxe?

O Bruno ficou sério e começou a puxar algo que estava debaixo da camisa. Ouvi um barulho de uma coisa desgrudando de sua pele e então surgiu uma revista toda amassada e suada.

Dei uma olhada na capa da publicação e logo me senti corando. A foto era de uma mulher pelada sentada sobre as pernas, escondendo os seios com os antebraços e com pétalas de rosa cobrindo sua vagina. Eu já havia visto algumas daquelas revistas na escola, elas costumavam passar de mão em mão, mas eu nunca tinha ficado com nenhuma. Para falar a verdade, eu costumava ficar nervoso diante delas e os meninos riam de mim. Secretamente eu não sentia as coisas que os meninos sentiam quando olhavam para mulheres peladas e isso me encucava.

- É minha vez de ficar com ela - falou o menino que tinha perguntado.

O Bruno jogou a revista para ele, que começou a fuçar página por página.

- Cadê as outras? - o Bruno perguntou.

Dois dos outros meninos também revelaram revistas que estavam escondidas. Uma era uma revista que não era só de mulher pelada, era uma revista de homens e mulheres fodendo. Os meninos falavam essa palavra o 
tempo todo. Tudo era foder, trepar, buceta, pica, punheta... A outra revista eu não consegui ver, porque o menino a deixou em cima da mesa e ninguém deu atenção para ela. A capa ficou brilhando com a luz do sol que ia morrendo e eu não consegui distinguir nada de nada, só brilho.

- Essas revistas tão muito batidas. A gente precisa arrumar umas novas - falou um dos garotos.

- Eu vou pra Alta Floresta amanhã, vou tentar catar umas do meu irmão que mora lá - Bruno disse.

Os meninos ficaram animados e quando isso acontecia eu sabia que havia uma chance de alguém se animar também para implicar com um dos menores.

- Olha a cara desse moleque, acho que ele nunca tinha visto isso.

O menino que segurava a revista de sacanagem estava mostrando as imagens para os meninos mais novos ao meu lado. Eu me sentia estranho quando olhava para aquilo, mas meus colegas estavam um pouco espantados. Até eu fiquei com vontade de rir.

- Nem devem ter pelo no saco ainda, quem deixou essas crianças virem com a gente? - o menino continuou provocando, agora se referindo a mim também.

- Deixa eles - o Bruno falou.

Mas o menino ainda perguntou:

- Vocês já são homens?

O rapaz estava se divertindo em nos maltratar. Ele fazia isso porque nós não costumávamos responder, com medo de levar uma sova, só que o Bruno estava do meu lado então eu achei que podia responder à pergunta dele. Mas eu não tinha entendido o que aquela anta havia perguntado, para mim não fazia sentido.

- A gente é homem, ué. Como assim virar homem?

- Tô perguntando se vocês já têm porra.

- Quê?!

Todo mundo riu de mim, até o Bruno. Fiquei um pouco decepcionado, com raiva e vergonha.

Então a voz do Bruno mudou e ele olhou bem na minha cara, como o Cabo costumava fazer quando chamava nossa atenção, com a diferença de 
que o Cabo tinha uma cara de poucos amigos e o Bruno te fazia se sentir um amigo.

- É que chega uma idade em que acontece uma coisa com o cara. Quando ele bate punheta sai uma coisa do pinto dele. É essa coisa que entra na mulher e vira um bebê. É quando o cara virou homem, saca?

De súbito entendi a pergunta e fiquei ainda mais nervoso, aquilo ainda não tinha acontecido comigo e eu não queria ser mais zoado. Fiquei sem saber o que dizer, então só assenti com a cabeça.

- Uma hora isso vai acontecer com você e você não vai ficar sem entender, como alguns aqui - o Bruno levantou um pouco a voz na hora de falar essa última parte e alguns meninos pareceram constrangidos.

No restante do tempo em que permanecemos no bar fiquei só ouvindo a conversa e gostava mais quando o Bruno falava. Ele tinha uns assuntos divertidos, mas alguns assuntos sérios também. Já tinha viajado para não sei onde, conhecido não sei o quê. Quando já nem dava mais para ver o sol, um dos meninos perguntou quem iria ficar com a terceira revista. A outra também era uma revista de sacanagem, só que toda de desenhos, histórias em quadrinho e outras ilustrações esquisitas. Eu nunca tinha visto uma assim.

- Todo mundo já viu essa - alguém falou.

- Vou levar de volta, então.

Eu queria ver aquela, era de desenho, tinha personagens, eu achei até que tivesse visto o Batman de relance numa das páginas quando o menino a agitou no ar.

- Posso ficar? - perguntei juntando coragem.

O menino me encarou.

- Não, você vai perder ela.

- Não vou, sério.

- Você vai cuidar dela e trazer de volta? - o Bruno questionou.

- Vou.

- Não pode deixar ninguém ver.

- Tá bom.

O garoto fez uma careta de descontentamento, mas me deu a revista. Os outros meninos menores ficaram me olhando um pouco admirados. 
- O que cês acham da gente dar uma passada na Rua das Véia? As meninas ficam mexendo com a gente quando a gente tá de farda - alguém falou.

Os meninos foram então para a Rua das Véia, mas eu disse que tinha que ir embora e me mandei, falei tchau paro o Bruno e ele sorriu para mim. Subi a avenida meio que correndo, eu morava lá em cima, perto de onde tinham feito uma pista para os ultraleves. O que eu queria mesmo era poder olhar a revista com calma e sozinho.

Naquela noite eu dormi tarde, porque fiquei olhando todos os desenhos, o jeito que o desenhista havia feito os corpos, como tinha feito aquelas expressões na cara dos personagens, uns olhos fechados, umas bocas abertas. Algumas histórias eram meio que de aventura, como a de um homem e de uma mulher que estavam num avião que havia sido atingido e eles tiveram que saltar de paraquedas numa ilha deserta. Outras eram meio malucas, como a de uma mulher que namorava o Batman e o Robin ao mesmo tempo. Ficar olhando aquilo fez o meu pau ficar duro, como quando eu mexia nele na hora do banho ou deitado na cama.

Quando terminei de ler, tive a ideia de tentar reproduzir os desenhos no meu caderno de artes. Me deitei de bruços na cama, olhava e tentava fazer o mais parecido possível, fiz algumas reproduções, principalmente dos homens. Eu gostava de como eram fortes e meio mal-encarados e de como os pintos eram diferentes uns dos outros. Fiquei pensando em como seria o pinto do Cabo e se ele fazia aquelas coisas que os personagens da revista faziam. E fiquei pensando se o pinto do Bruno era mais para igual ou mais para diferente do meu.

Fiquei nisso até que teve uma hora em que me flagrei desenhando o rosto do Bruno no desenho que eu estava fazendo. Sim, eu tinha feito o Bruno, colado na mulher. Achei legal, mas não muito legal. Dava para melhorar. Então pensei com muita força em tudo que eu tinha descoberto sobre o corpo do Bruno quando o vi só de cueca trocando de roupa no quartel no dia em que a fanfarra se apresentou. Fiz outro desenho, com dois rapazes, só que um era o Bruno e o outro era eu, pelados, um olhando paro o outro.

O desenho ficou tão bonito que eu quis colorir. E lá estava eu concentrado nos traços, nas cores, mas sem conseguir parar de pensar no Bruno só de cueca, no seu sorriso, no toque do seu braço no meu ombro quando me carregou na bicicleta, quando me olhou nos olhos e falou comigo, o barulho 
da revista desgrudando da pele dele. No caderno, aquele Bruno com um meio sorriso, imponente, herói.

Fui pintando aquilo obstinado, de bruços na cama. Eu iria olhar para aquele desenho todo dia, só que ninguém nunca poderia saber, porque era coisa de bicha e teria que ser o meu segredo. Mesmo assim eu iria desenhar mil Brunos para ter comigo. Eu estava pintando cada vez mais rápido, mas deixei o lápis escapar quando senti uma coisa muito forte, que eu nunca tinha sentido. Era como se meu corpo estivesse vibrando inteiro e muito rápido, como se eu estivesse caindo numa cachoeira enorme ao mesmo tempo em que eu era a própria cachoeira, como se uma lua e um sol tivessem se acendido na parte de baixo de mim. Em um primeiro momento, não entendi o que estava acontecendo comigo. Minha vista ficou um pouco turva e segurei a respiração. Era tão gostoso e tão inesperado. Um pouco depois inspirei profundamente e me virei na cama, fiquei olhando para o teto enquanto ainda sentia um tipo de coisa boa meio que dentro e meio que fora de mim. Meu pinto latejava. Me sentei na cama e olhei para o interior da cueca, que estava molhada. Da cabeça do meu pau escorria um líquido leitoso.

Aquilo era estranho e eu estava assustado com meu próprio corpo. Era como se eu tivesse entrado em contato com um tipo de mágica ancestral ou ultrapassado um limite desconhecido. Mas eu sabia o que tinha acontecido, estava bem ali, na revista. E me lembrei do Bruno falando: "Uma hora isso vai acontecer com você e você não vai ficar sem entender". Gostei ainda mais do Bruno naquele momento.

Jurei para mim que ele seria o primeiro a saber. 


\title{
0 exercício da parresía no relato de mim mesma: o que se passa comigo ou o que se passa conosco?
}

\author{
Tatiana Lionço
}

Dedico este texto ao amigo

Cristiano Lucas Ferreira, a quem me solidarizo.

Dada a complexidade sociológica e histórica das interfaces entre religião e política no Brasil, em meus esforços acadêmicos na produção de conhecimento sobre o tema, não pretendi esgotar a questão das estratégias adotadas por extremistas e fundamentalistas religiosos na política brasileira senão pela parcialidade da compreensão decorrente da minha própria experiência biográfica de proximidade com o fenômeno em questão. Isso leva necessariamente à pergunta sobre qual haveria de ser a minha posição na construção de conhecimento sobre o fenômeno. Parto aqui do pressuposto de que o melhor caminho para a afirmação do lugar de fala não é o de um fundacionismo identitário tal como problematizado por Butler (1998, p. 08), recuperando então a sua sugestão de que necessariamente a reflexão sobre um dado sujeito partiria do questionamento de "quais são as histórias institucionais de sujeição e subjetivação que me 'posicionam' aqui e agora?"

Meu posicionamento neste processo só ganha sentido por meio da recuperação dos signos a partir dos quais fui referida e interpelada nos ataques morais sofridos. São os signos por meio dos quais sou referida nos discursos de outres que melhor contribuem para construir um posicionamento na produção parcial de sentido sobre o fato social, que coincide, no meu caso, com a experiência concreta de relacionalidades estabelecidas entre mim e os meus antagonistas políticos afeitos à ofensiva antigênero. As difamações contra mim veiculadas elegeram, ora 
a representação de minha pessoa a partir do signo psicóloga, mas também ora professora, ora ativista feminista. É em torno desta localização que buscarei construir meu posicionamento, pois "é impossível fazer um relato de si mesmo fora da estrutura de interpelação" (BUTLER, 2015a, p. 51). Assim, interessará considerar também, ainda que brevemente, a Psicologia, a universidade e ativismo feminista, já que, ao menos nos discursos ao meu respeito, eu representaria (ou aparentaria?) ser psicóloga, professora e feminista.

Tenho buscado compreender o que é possível fazer do que fazem/ fizeram de mim, primando pela defesa de outra lógica de relacionalidade, qual seja, a que não intenciona destruir o outro em sua própria precariedade (BUTLER, 2015b). Uma das características da perspectiva aqui adotada é a de que se está assumindo o desafio democrático de conviver com aqueles que acreditamos incorrer em falta ética ou em erro moral (NUSSBAUM, 2008).

Relatar a mim mesma só faz sentido dada a intencionalidade relacional e, portanto, o caráter social implicado na consideração dos fatos biográficos. Sabemos que a autobiografia tem sido adotada como metodologia de pesquisa para a produção de conhecimento sobre trajetórias de professoras/ es, notadamente como efeito "da insatisfação das ciências sociais em relação ao tipo de saber produzido e da necessidade de uma renovação dos modos de conhecimento científico" (NÓVOA, 2013, p. 18). No campo da educação, tais pesquisas intencionam reconhecer as dimensões pessoais nos espaços institucionais, de modo a contribuir para a compreensão de que o/a professor/a, assim como outros atores sociais, "define-se pelo que consegue fazer com o que os outros fizeram dele" (NÓVOA, 2013, p. 25). Existem pesquisas que visam conhecer por meio de diários autobiográficos as características das relações estabelecidas por professora/es em sala de aula e como a narrativa da própria experiência e sobre si mesma contribui para dar sentido à prática (HOLLY, 79).

O que está em jogo neste contexto analítico não é, no entanto, a construção de uma identidade no exercício profissional, seja como professora, seja como psicóloga. A autobiografia não corresponde aos objetivos de meus enunciados, pois não almejo delinear uma história biográfica, mas sobretudo apoiar-me no que Rago (2013) denomina espaço autobiográfico para construir análises sobre o momento histórico e político brasileiro em uma perspectiva mais abrangente, remetendo a considerações 
propriamente sociológicas sobre a incidência do fundamentalismo religioso no cenário político brasileiro contemporâneo, com ênfase em seu impacto sobre a regulação normativa da educação nacional e sobre a Psicologia como profissão (também referida a marcos legais e outros atos normativos próprios do Sistema Conselhos de Psicologia).

Por meio da recuperação de narrativas de feministas em espaços autobiográficos, Rago (2013) desenvolveu uma análise da conjuntura política e dos processos de mobilização sociais dos feminismos a partir dos relatos de vida, mas agregando sentido analítico a partir de seu próprio esforço de situar tais narrativas ao contexto social e político da época da ditadura. A escrita de si, na perspectiva da autora, remeteria ao estabelecimento de uma relação consigo mesma que pressuporia a prática política da parresía. Sugere que a escrita de si "constitui uma chave analítica pertinente para pensar as práticas de resistência nas narrativas dessas feministas que recusam a ser governadas" (RAGO, 2013, p. 55).

Para enfatizar o caráter social visado no relato de parte de minha trajetória biográfica, portanto, adoto o conceito proposto por Butler (2015a) de relatar a mim mesma posto que o mesmo implica a noção de interpelação e relacionalidade. Assim como a escrita de si, relatar a si mesma pode carregar ímpeto parresiasta, ou seja, o da fala franca que desvela uma verdade de interesse coletivo, a despeito das consequências para o próprio sujeito que enuncia dada verdade. A noção de parresía amplamente discutida por Foucault (2011) implica a função eminentemente política deste modo de dizer. Ainda, a parresía remete a um compromisso com a coletividade, de modo que aquele que enuncia certa verdade o faz correndo riscos, colocando outrem em risco, mas em interesse do bem comum ou da vida social. A parresía ética seria aquela em que o sujeito cuida dos outros ao cuidar de si próprio, sendo que "se protejo a minha vida é precisamente no interesse da cidade. É do interesse da cidade proteger o discurso verdadeiro, a veridicção corajosa que estimula os cidadãos a cuidar de si mesmos" (FOUCAULT, 2011, p. 78).

O exercício de relatar a mim mesma aqui empreendido, portanto, assume intencionalidade política e visa desvelar - a partir de um saber localizado em minha posição social parcial -, aspectos de relacionalidade implicados nas estratégias adotadas por fundamentalistas religiosos na política nacional, mas também nas condições para o que costumamos denominar resistência. O elemento estruturante do fundamentalismo 
religioso é a oposição à ética democrática e, portanto, ao reconhecimento da diversidade social e moral. As características desse elemento seriam passíveis de apreensão por meio da análise dos caminhos que caracterizam os modos de interpelação dos fundamentalistas religiosos, que proponho aqui como: o caminho da imposição normativa, o caminho da censura e o caminho da vergonha.

No que se refere ao que denomino o caminho da imposição normativa, assistimos a uma progressiva polêmica moral em torno dos tímidos esforços empreendidos para a implementação do Programa Brasil sem Homofobia no setor educação, já passíveis de referência atual a um passado rompido, remetido aos governos petistas na gestão federal. Ainda que haja fundamentos constitucionais e legais para a educação em gênero e sexualidade nas escolas, a partir de 2011, ano da polêmica posição da então presidenta Dilma na retirada dos materiais didáticos produzidos para subsidiar práticas pedagógicas de combate à homofobia, lesbofobia, bifobia e transfobia, é necessário compreender que têm se desdobrado diversas iniciativas de atribuição normativa de (aparente ou mesmo formal) ilicitude à educação em gênero e sexualidade. A ideia de uma "ideologia de gênero" passou a ser usada recorrentemente para desqualificar tais estratégias pedagógicas, derivando na supressão dos termos gênero, orientação sexual e identidade de gênero dos planos de educação a partir de 2014, mas também em projetos de lei que intencionam censurar por força da lei tais temas na prática didático-pedagógica.

A proposição dos Projetos de Lei intitulados Escola sem Partido, capilarizada nos três níveis do poder legislativo, visa censurar o debate sobre gênero e sexualidade nas escolas, ameaçando, portanto, uma política de Estado (educação cidadã por meio de parâmetros curriculares de formação para a ética democrática) pela ascensão do conservadorismo extremista que tem como carro chefe bancadas fundamentalistas em câmaras legislativas. Essa situação se agravou a partir de 2019, quando o governo Bolsonaro passou a adotar, no âmbito do poder executivo, presunção de legitimidade para dar curso à política educacional a partir da explícita rejeição à suposta "ideologia de gênero", ainda que não tenha sido aprovado o projeto de lei Escola sem Partido no âmbito legislativo federal. Da mesma forma, pudemos observar impactos da adesão do atual governo à ofensiva antigênero nos posicionamentos oficiais internacionais do Estado brasileiro no que se refere à agenda de direitos humanos, e em especial de direitos sexuais, 
retrocedendo em relação a posicionamentos anteriormente adotados favoráveis ao reconhecimento do gênero, da orientação sexual e da identidade de gênero como determinantes de vulnerabilidades ao prejuízo no gozo de direitos sociais. É sempre bom lembrar que preconceito baseado em sexo é afirmado na Constituição Federal como inconstitucional.

No âmbito da Psicologia brasileira, as ofensivas para a imposição normativa do retrocesso na afirmação de direitos sexuais recaíram sobre a regulação ética da profissão, notadamente relativa à não discriminação das homossexualidades e vetos às terapias de reversão da orientação sexual (Resolução CFP 01/99). O Projeto de Decreto Legislativo n. 234/2011, arquivado em 2013, visava sustar os parágrafos da resolução que tratavam especificamente do veto às terapias de reversão da orientação sexual e do pronunciamento público de profissionais de Psicologia sobre concepções patologizantes sobre as homossexualidades. A justificativa para a proposição do decreto legislativo era a de que o Conselho Federal de Psicologia havia extrapolado seu poder regulamentador, restringindo a autonomia de profissionais de Psicologia no exercício profissional e na expressão da livre consciência. Após o arquivamento, a ofensiva foi relançada em 2016 por meio do Projeto de Decreto Legislativo n. 539/2016, que visava sustar o inteiro teor da Resolução CFP 01/99, baseado no argumento de que o Conselho Federal de Psicologia havia ultrapassado suas competências. Como tais proposições legislativas não decorreram em alterações da normativa por meio dos ritos democráticos de deliberação do poder legislativo, em 2017 uma liminar da Justiça Federal impôs uma interpretação à Resolução CFP 01/99 de modo a alterar o sentido originário da normativa. A partir de uma ação pública apresentada por um conjunto de profissionais de Psicologia, a decisão judicial entendeu que o direito à pesquisa científica e exercício profissional dos mesmos não deveria ser cerceado pelo veto à patologização e reversão da homossexualidade afirmados pela resolução, abrindo, assim, brecha legal para a realização de terapias de reversão da orientação sexual supostamente por interesses científicos. Em 2020, finalmente, a tensão formal se encerra em decorrência de decisão da suprema corte atestando legitimidade do conselho de classe no estabelecimento de normativas para o exercício ético da profissão.

Da mesma forma, tão logo a Resolução CFP 01/2018, que trata da não patologização da travestilidade e transexualidade fora apresentada, em 29 de janeiro de 2018, nova ofensiva jurídica visou a destituição de legitimidade do 
conselho de classe profissional em regular eticamente a profissão, por meio da instauração, pelo Ministério Público Federal de Goiás, de procedimento preparatório para apurar ações ou omissões ilícitas do CFP no que se refere ao impedimento na atuação profissional de psicólogos diante da normativa em questão. Tais medidas jurídicas denotam disposição conservadora para a imposição normativa de limites ao processo democrático de deliberação de normas éticas para o exercício profissional, que contam no sistema conselhos de Psicologia com os fóruns deliberativos dos Congressos Nacionais da Psicologia e decisões da Assembleia de Políticas, da Administração e das Finanças (APAF).

Em relação ao que denomino o caminho da censura, a estratégia adotada é a da identificação de grupos sociais perigosos e afeitos à ruína moral, contribuindo para uma lógica autoritária de poder semelhante àquela descrita por Arendt (2012) como a construção do inimigo comum. O inimigo comum: homossexuais adjetivados como pedófilos, feministas e LGBT identificadas como abominação e inimigas da família.

O movimento Escola sem Partido buscou incidir sobre a educação nacional por meio da proposta de legalidade da censura do debate sobre gênero e sexualidade nas escolas, pendendo para iniciativas de criminalização do que afirmam como assédio ideológico na prática docente. Tais preceitos, vale notar, se sedimentaram na proliferação de ataques morais contra ativistas e pesquisadoras/es, referidos como risco social a ser combatido e tornados assim alvos de ofensivas para a destruição da reputação, visando o seu silenciamento e o seu descrédito social, moral e mesmo institucional.

No marco histórico de defesa dos direitos humanos, a incidência da moralidade religiosa na política tende à recusa da universalidade do direito à dignidade humana e na supressão, ou ao menos limitação, dos direitos à participação política de grupos sociais ou comunidades morais moralmente não hegemônicas, que deixariam de dispor de legitimidade no direito de enunciação, em seus próprios termos, do modo como se representam a si mesmos e do sentido que conferem a seus pleitos políticos. O caminho da censura se fundamenta, portanto, na justificativa ética e moral para a atribuição de abominação a grupos sociais identificados como risco social a ser combatido. 
A censura ao debate público sobre gênero e sexualidade ganhou contornos sensacionalistas no Brasil quando, em 2016, a exposição intitulada Queer Museu foi impedida de permanecer aberta ao público, decorrendo na convocação do curador responsável pela mesma, Gaudêncio Fidelis ${ }^{1}$, a comparecer, sob condução coercitiva, a uma audiência pública da Comissão Parlamentar de Inquérito sobre Maus Tratos Contra Crianças cujo presidente é o Senador Magno Malta, integrante da bancada evangélica.

Grande parte dos esforços de fundamentalistas religiosos na legalização da censura se voltam para a regulação da educação nacional, embora seja importante considerar a desqualificação moral que recaiu sobre obras artísticas e mesmo na retaliação à presença de acadêmica mundialmente reconhecida nos estudos feministas contemporâneos, atacada simbolicamente como bruxa em praça pública e atacada fisicamente e moralmente durante trânsito pelo país ${ }^{2}$. Diferentemente das análises empreendidas recentemente (como é o caso da pesquisa desenvolvida pelo Observatório de Sexualidade e Política que identificou o evento relacionado a esta campanha e ataque moral contra Judith Butler como o corolário da articulação de destruição moral como estratégia política antigênero em tempos eleitorais), venho aqui lembrar que é bem possível, mas também necessário, reconhecer que tais processos se originaram anos antes do marco sugerido na referida pesquisa, que a partir de uma lógica meritocrática sobre o valor político de fatos e pessoas determinou a atenção sobre a destruição de reputação apenas quando atingiu uma celebridade internacionalmente reconhecida.

Por fim, o caminho da vergonha como estratégia de desdemocratização pode ser referido à saga pela censura e destruição moral de pessoas comprometidas com a agenda de direitos sexuais na educação. Desdobrou-se, da ânsia impositiva por normatizar a censura, um fenômeno de perseguição política contra ativistas e professoras/es que defendem publicamente a necessidade de intervir sobre a LGBTfobia por meio da educação, que já

\footnotetext{
${ }^{1}$ Gaudêncio Fidelis se pronuncia sobre a intimação a comparecer a audiência na CPI dos Maus Tratos: https://gauchazh.clicrbs.com.br/cultura-e-lazer/artes/noticia/2017/11/paragaudencio-fidelis-cpi-dos-maus-tratos-virou-tribunal-de-inquisicao-para-profissionais-da-artecjabec8fd05k701mvgbnvv8ya.html

2 Judith Butler comenta as agressões sofridas no Brasil: http://www1.folha.uol.com.br/ ilustrissima/2017/11/1936103-judith-butler-escreve-sobre-o-fantasma-do-genero-e-o-ataquesofrido-no-brasil.shtml
} 
transcorre por quase uma década e está, portanto, longe de ter iniciado com a visita de Judith Butler ao Brasil em 2017. O marco de referência do início da produção de materiais discursivos e audiovisuais voltados à destruição da reputação de ativistas e pesquisadoras/es pode ser facilmente identificado como o IX Seminário LGBT da Câmara dos Deputados realizado em 2012, intitulado Respeito à diversidade se aprende na infância. A partir de então se iniciou, explicitamente e ostensivamente, um processo de associação entre pedofilia e militância por direitos sexuais no Brasil. O que ocorreu em 2017 foi a ampliação da associação da pedofilia a exposições e performances artísticas, desencadeando amplo debate na mídia e decorrendo em episódios de agressão física, além de moral ${ }^{3}$.

Da mesma forma, mas note-se que há mais tempo, figuras públicas que discutem a questão do gênero e da sexualidade na educação passaram a sofrer retaliação moral sendo associadas diretamente à apologia da pedofilia, como é o meu caso, mas também o do professor de educação infantil e pesquisador Cristiano Lucas Ferreira. É necessário notar que vivemos, há quase uma década, sob efeito de tais ofensivas morais. Engana-se quem presume, precipitadamente, que estaríamos apegados excessivamente ao referido marco de 2012: em 2014 eu também tive meu rosto e nome próprio usados em vídeo de campanha política de pastor, exemplificando seu alarde contra o espírito do anticristo; em 2016 fui mencionada como professora que defenderia que crianças teriam muito a aprender com pedófilos no vídeo intitulado Marco Feliciano Renuncia, produzido pelo próprio deputado pastor; em 2018 descobri que eu estava com meu rosto e nome próprio afixados na porta do gabinete do vereador Carlos Bolsonaro na Câmara dos Vereadores do Rio de Janeiro em seu "mural da verdade", bem como descobri que estava mencionada nominalmente em livro de autoria do Marco Feliciano, em que o mesmo associa nosso debate sobre o Escola sem Homofobia ao ensino de fisting para adolescentes em escolas; e na sequência constatei que novamente meu nome próprio e rosto foram expostos em post no Twitter de Eduardo Bolsonaro, que então compartilhou/reatualizou o vídeo produzido por Jair Bolsonaro em 2012 contra nós, participantes do IX Seminário LGBT da Câmara, como prova de que eram fake news as

\footnotetext{
${ }^{3}$ A notícia sobre a agressão em protesto de repúdio a uma performance no MAM, associando-a à pedofilia, pode ser recuperada em http://cultura.estadao.com.br/noticias/artes, protesto-contraperformance-no-mam-termina-em-agressao,70002022348
} 
matérias que alegavam, entre 2018 e 2019, que o "kit-gay" e "Seminário LGBT infantil" seriam fake news.

Neste aspecto, resta dizer que pude assim constatar que não se combatem as fake news por meio de fake news, firmando assim minha explícita discordância em relação à estratégia de campanha política adotada pelo Partido dos Trabalhadores na candidatura de Fernando Haddad em 2018, que optou por fingir que nunca estivemos no Congresso Nacional debatendo o conjunto de materiais produzidos em 2011 pelo Ministério da Educação (inclusive, na gestão do então ministro Haddad), optando por twittar de modo leviano e irresponsável que não existia base alguma para que se pudesse alegar "kit-gay" ou "Seminário LGBT infantil". Trocando em miúdos, afirmo aqui que a hipocrisia e a miopia política da esquerda, no caso, decorreu no abandono político de pessoas que, inclusive, haviam participado e, portanto, movido suas próprias proposições de governo, agora pelo visto devidamente recalcadas.

A condição vexatória a que me refiro, portanto, não consiste apenas em ser alvo de xingamentos e narrativas odiosas por parte de extremistas conservadores e de fundamentalistas religiosos: a vergonha a que nos condicionaram neste cenário político foi a do descrédito, diante de nossos oponentes políticos, quanto à legitimidade de nossa defesa. Fomos entregues à própria sorte, ou talvez, no meu caso, condicionada ao reconhecimento forçado e processual quanto ao meu desvalor político, seja diante de partidos políticos, "aliados/as políticos/as", incluindo aí nossos/as supostos/as colegas parlamentares, ativistas e acadêmicos/as. O tamanho do vexame que percorri neste caminho da vergonha foi o do arquivamento de representações apresentadas ao poder público, a do silêncio reiterado da instituição na qual sou servidora pública federal diante de variados anúncios de ataques e pedidos de ajuda, e no rumor persistente, no âmbito dos espaços de ativismos por direitos sexuais, de que era inoportuno que eu falasse a respeito de tais episódios, como se irrelevantes fossem, ou como se eu não representasse essas lutas.

A complexidade dos processos de reparação, no entanto, recai no status dos próprios autores de tais injunções da vergonha e atribuição de imoralidade/criminalidade/irrelevância política/ilegitimidade: estou falando a respeito de parlamentares protegidos pela imunidade parlamentar e que abusam da livre expressão na ofensa contra pessoas usadas como bodes 
expiatórios de seu processo de construção do inimigo a ser combatido. Por outro lado, preciso também mencionar a conivência das instituições públicas, das supostas alianças políticas e de outras/os ativistas, que parecem haver compreendido que não teriam nenhuma relação com o fenômeno, ou que, por outro lado, eu não teria nenhuma relação com a luta.

Entendo que a vulnerabilidade não foi ou é apenas minha, mas de todas as pessoas que pesquisam ou se dedicam ao acompanhamento da agenda política de direitos sexuais e de direitos reprodutivos no país. Quero explicitar e registrar que, desde a minha ocupação de cargo público como servidora federal, por meio de concurso público realizado em 2014 e com posse efetivada no início de 2015 , levei ao conhecimento da Universidade de Brasília que vinha sofrendo retaliações morais desde 2012 em função de minha trajetória acadêmica e profissional na construção de marcos para a garantia de direitos para a população de lésbicas, gays, bissexuais, travestis e transexuais (LGBT) no Brasil. Fiz constar não apenas na prova oral para defesa de conhecimento na ocasião do concurso público, como argumentei a respeito dos fatos nos relatórios parcial e final do estágio probatório, inclusive para justificar meus interesses acadêmicos, que comprometidamente voltei para a busca de compreensão do que se passa conosco - e não apenas comigo. Vale salientar que minha trajetória abrange o envolvimento direto no processo democrático de construção de políticas públicas para a população $\mathrm{LGBT}^{4}$, bem como na análise de políticas públicas de saúde e educação considerando a diversidade sexual ${ }^{5}$, tendo passado a

\footnotetext{
${ }^{4}$ Participei como consultora técnica dos processos de articulação para a construção de marcos normativos para a atenção à saúde de LGBT no âmbito do Ministério da Saúde, tais como o Processo Transexualizador no SUS (2008) e Política de Atenção Integral à Saúde da População LGBT no SUS (2011). Ainda, no âmbito da Secretaria Especial de Direitos Humanos da Presidência da República, fui a consultora responsável pela sistematização do texto-base da I Conferência Nacional GLBT (2008). No Sistema Conselhos de Psicologia, participei da elaboração da Nota Técnica sobre o Processo Transexualizador e demais formas de assistência às pessoas trans do CFP (2013).

${ }^{5}$ Costa, A. M., \& Lionço, T. (2006). Democracia e gestão participativa: uma estratégia para a eqüidade em saúde?Saúde e Sociedade, 15(2), 47-55; Lionço, T. (2008). Que direito à saúde para a população GLBT? Considerando direitos humanos, sexuais e reprodutivos em busca da integralidade e da eqüidade. Saúde e Sociedade, 17(2), 11-21; Lionço, T., \& Diniz, D. (2008). Homofobia, silêncio e naturalização: por uma narrativa da diversidade sexual. Revista Psicologia Política, 8(16), 307-324.; Lionço, T. \& Diniz, D. (2009). Homofobia e Educação - um desafio ao silêncio. Brasília: Editora UnB/ Letras Livres; Diniz, D.; Lionço, T. \& Carrião, V. (2010). Laicidade e Ensino Religioso no Brasil. Brasília: Editora UNESCO/Letras Livres; Arán, M., Murta, D., \& Lionço, T. (2009). Transexualidade e saúde pública no Brasil. Ciência \& Saúde Coletiva,14(4), 1141-1149; Lionço, T. (2009). Atenção integral à
} 
redirecionar parte de meus interesses acadêmicos para a análise da ascensão do fenômeno do fundamentalismo religioso na política nacional como efeito da realidade política com a qual tivemos que nos deparar ${ }^{6}$. Tal deslocamento de investimento acadêmico decorreu não apenas do reconhecimento de que se faz urgente compreender um dos fatores sociais e políticos que comprometem a garantia de direitos para esta população, mas também da necessidade de produção de sentido sobre uma experiência biográfica de vulnerabilidade à violação moral e ao sofrimento psíquico, com deterioração de minhas relações sociais e institucionais.

Os fatos, incluindo aqueles que ocorreram na vigência do exercício de meu cargo público, como mencionei anteriormente nos episódios de 2016, 2018 e 2019, sempre foram por mim relatados institucionalmente. É importante mencionar que tais fatos estão associados à minha atividade profissional e acadêmica, não consistindo em evento biográfico irrelevante para nosso debate acadêmico ou mesmo político. Na mesma medida, eu gostaria de explicitar que teria sido menos difícil enfrentar os efeitos deste processo de retaliação moral caso as instituições ou coletividades houvessem compreendido, junto comigo, que este era um grave problema nosso, e não apenas meu infortúnio pessoal.

Nos últimos anos participei diretamente de esforços, no âmbito do Sistema Conselhos de Psicologia, para a construção de marcos de referência para categoria profissional no que se refere à laicidade na ciência psicológica e na profissão, bem como à defesa da Psicologia brasileira contra as ofensivas fundamentalistas contra as normativas da categoria de classe, notadamente aquelas que se referem à não patologização da homossexualidade, travestilidade e transexualidade (Conselho Federal de Psicologia - CFP, 1999; CFP, 2018). Minha participação consiste na integração

saúde e diversidade sexual no Processo Transexualizador do SUS: avanços, impasses, desafios. Physis: Revista de Saúde Coletiva, 19(1), 43-63.

${ }^{6}$ Lionço, T. Laicidade, gênero, sexualidade e fundamentalismo religioso cristão no Brasil, in Plataforma de Direitos Humanos, Econômicos, Sociais, Culturais e Ambientais - DHESCA Brasil. (Org.). Relatorias em Direitos Humanos. Informe: 2012-2014. Curitiba: Terra de Direitos, 2015, p. 21-31. Lionço, T. (2016). Criminalização do assédio ideológico nas escolas: ideologia de gênero como argumento central na disputa fundamentalista da política de educação. In: Rodrigues, A.; Monzeli, G.; Ferreira, S. R. da S. (Org.). A política do corpo - gênero e sexualidade em disputa. 1ed.Vitória/ ES: EDUFES, p. 145-160.

Lionço, T. (2017). Psicologia, democracia e laicidade em tempos de fundamentalismo religioso no Brasil. Psicologia: Ciência e Profissão, 37(n. spe), 208-223. 
de estratégias coletivas de diálogo e construção de encaminhamentos, tais como o Grupo de Trabalho Laicidade instituído pela Assembléia de Políticas, da Administração e das Finanças (APAF) do Sistema Conselhos de Psicologia (membro no período dezembro de 2013 a dezembro de 2016, passando a reintegrar o grupo de trabalho em 2018 por indicação do Conselho Regional de Psicologia do Distrito Federal), bem como em reuniões técnicas de defesa das Resoluções CFP 01/1999 e CFP 01/2018 articuladas em 2017 e no corrente ano pela atual gestão do Conselho Federal de Psicologia. Tais normativas passaram nos últimos anos a sofrer ofensivas legislativas por parte de parlamentares organizados em bancadas de fé religiosa bem como ofensivas jurídicas. Vale ressaltar que no IX Congresso Nacional de Psicologia (CNP), principal espaço de deliberação democrática da categoria, foi aprovada a necessidade de construção de uma Política Nacional de Psicologia e Laicidade (CNP, 2016).

Esta direção política da Psicologia brasileira requer amplos esforços no debate público sobre laicidade no exercício profissional, mas também dedicação acadêmica sobre a relação entre a Psicologia e este princípio de proteção à diversidade moral e social nas práticas de governo e, portanto, na implementação de políticas públicas, nas quais profissionais de Psicologia participam em diversos setores.

Nos últimos anos tenho dedicado ainda esforços acadêmicos na produção de conhecimento por meio de pesquisa sobre a ascensão do fundamentalismo religioso na política nacional, sobretudo no que se refere à agenda dos direitos sexuais e do direito à educação, mas também sobre a sua incidência sobre a própria Psicologia brasileira comprometendo os consensos democráticos da categoria de classe profissional no que se refere ao reconhecimento da diversidade sexual e de gênero. Tais publicações de resultados de pesquisa denotam a intencionalidade política de minha produção acadêmica que se coaduna paradoxalmente à compreensão e defesa de uma universidade que cumpra os ideários de Darcy Ribeiro na fundação da Universidade de Brasília, a saber, os de uma universidade necessária à transformação do problema Brasil em sua complexidade histórica e política (RIBEIRO, 1986). Trata-se de uma decisão por uma trajetória acadêmica engajada na crítica aos processos políticos que comprometem o projeto de democratização brasileiro, conciliando a produção acadêmica à luta histórica por garantia de direitos, primando 
pela construção de uma Psicologia crítica e politicamente engajada na defesa da democracia.

Por fim, espero que o meu ímpeto parresiasta ao relatar a mim mesma possa reverberar, de modo a sensibilizar e a mobilizar o comprometimento coletivo diante de tais ofensivas. As consequências da experiência relatada, contextualizada em minhas ponderações analíticas sobre como compreendo que desvelam inteligibilidade sobre as tensões políticas e sociais contemporâneas, são graves e merecem consideração. No meu caso, após tantas peripécias e desenganos, resta comentar que: não sou mais professora de Psicologia; não reconheço mais a universidade como espaço seguro e de reconhecimento; estou muito ciente de minha trajetória e das minhas contribuições para a garantia de direitos sexuais no país; e estou aparentemente no último fôlego de disponibilidade. Eu que lute? Mas então qual haveria de ser a minha luta, a partir de agora? Respondo apenas por mim? 


\section{REFERÊNCIAS}

ARENDT, H. Origens do totalitarismo - antissemitismo, imperialismo, totalitarismo. São Paulo: Companhia das Letras, 2012.

Brasil. Programa Brasil sem Homofobia: Programa de Combate à Violência e à Discriminação contra GLTB e Promoção da Cidadania Homossexual. Brasília: Conselho Nacional de Combate à Discriminação/Ministério da Saúde, 2004. Disponível em: http://bvsms.saude.gov.br/bvs/ publicacoes/brasil sem homofobia.pdf. Acesso em: 20 jan. 2018.

BUTLER, J. Relatar a si mesmo - crítica da violência ética. Belo Horizonte: Autêntica Editora, 2015a.

BUTLER, J. Quadros de guerra - quando a vida é passível de luto?. Rio de Janeiro: Civilização Brasileira, 2015b.

BUTLER, J. A vida psíquica do poder - teorias da sujeição. Belo Horizonte: Autêntica Editora, 2017.

Conselho Federal de Psicologia - CFP. Resolução CFP Nº1/99, de 22 de março de 1999. Estabelece normas para a atuação dos psicólogos em relação à questão da orientação sexual. Brasília, DF: CFP, 1999. Disponível em: https://site.cfp.org.br/wp-content/uploads/1999/03/ resolucao1999_1.pdf.

Conselho Federal de Psicologia - CFP. Resolução CFP Nº 01/2018, de 29 de janeiro de 2018. Estabelece normas para a atuação de psicólogas e psicólogos em relação às pessoas transexuais e travestis. Brasília, DF: CFP, 2018. Disponível em: http://site.cfp.org.br/wpcontent/uploads/2018/01/Resolu\%C3\%A7\%C3\%A3o-CFP-01-2018.pdf.

Congresso Nacional da Psicologia - CNP. Cadernos de deliberação do IX CNP - Psicologia no cotidiano por uma sociedade mais democrática e igualitária (versão preliminar), 2016. Disponível em: http://9cnp.cfp.org.br/wp-content/uploads/sites/20/2016/02/CFP_CadCNP_ Deliberacoes_WEB.pdf. Acesso em: 03 fev. 2018.

FOUCAULT, M. A coragem da verdade. São Paulo: Martins Fontes, 2011.

HARAWAY, D. Saberes localizados - a questão da ciência para o feminismo e o privilégio da perspectiva parcial. Cadernos Pagu, (5), p. 07-41. 1995.

HOLLY, M. L. Investigando a vida profissional dos professores: diários biográficos. IN: NÓVOA, A. Vidas de professores. Porto: Porto Editora, 2013, p. 79-110.

NUSSBAUM, M. Liberty of conscience: in defense of America's tradition of religious equality. New York, NY: Basic Books. 2008.

NÓVOA, A. Os professores e as histórias da sua vida, IN: NÓVOA, A. Vidas de professores. Porto: Porto Editora, 2013, pag. 11-30.

RAGO, M. A aventura de contar-se - feminismos, escrita de si e invenções da subjetividade. Campinas: Editora da Unicamp, 2013.

RIBEIRO, Darcy. Universidade para que? Brasília: Editora da UnB, 1986. 
PARTE II

\section{DEMOCRACIA, \\ POLÍTICAS \\ PÚBLICASE \\ DIREITOS}




\title{
A GESTÃO DA ABEH ENTRE O GOLPE E A "FACADA"
}

\author{
Luma Nogueira Andrade
}

Este texto tem como objetivo apresentar as ações da Associação Brasileira de Estudos da Homocultura (ABEH) no recorte temporal que corresponde a 2017 e 2018, um dos períodos mais sangrentos para população LGBTQI+ (Lésbicas, Gays, Bissexuais, Travestis, Transexuais, Queer, Intersexuais) do Brasil, considerando os dados de assassinatos da referida população. A intenção é dar continuidade a análise que fiz sobre a história da referida instituição no livro História do Movimento LGBT no Brasil ${ }^{7}$. O biênio estudado, que equivale ao tempo em que fui presidenta da $A B E H$, foi marcado por profundas mudanças na sociedade civil, na política e no Estado Brasileiro, resultado da mobilização política, jurídica e midiática que destituiu Dilma Vana Rousseff, a primeira mulher eleita à Presidência da República Federativa do Brasil. O suposto impeachment, ocorrido em 31 de agosto de 2016 e registrado na História como o Golpe de $2016^{8}$, permitiu o avanço do conservadorismo e seu fortalecimento na disputa eleitoral de 2018.

A extrema direita se aproveitou dos acontecimentos de 2016 e começou a construir estratégias para manipular parte da opinião pública, criando e disseminando fake-news ao longo de 2017 e 2018, usando as redes sociais para atacar os opositores e as opositoras, fazendo uso das mídias alternativas para criar uma estratégia de comoção social em torno do suposto "Messias", que conseguiu se tornar um arremedo de mártire através da facada que sofreu em 06 de setembro de 2018, próximo da eleição presidencial que aconteceu neste mesmo ano. $\mathrm{O}$ acontecimento, que gerou alvoroço em

\footnotetext{
${ }^{7}$ ANDRADE, Luma. ABEH: Uma história de resistencia e produção de conhecimento. In.: GREEN, James Naylor; QUINALHA, Renan; CAETANO, Marcio; FERNANDES, Marisa (Org.). História do Movimento LGBT no Brasil. 1.ed. São Paulo: Alameda, 2018, p. 501-514.

${ }^{8}$ BESSONE, T.; MAMIGONIAN, B.G.; MATTOS, H. (Orgs.). 2016. Historiadores pela Democracia - O golpe de 2016: a força do passado. São Paulo, Editora Alameda, p. 283.
} 
parte da sociedade brasileira, justificou a ausência do mesmo nos debates públicos. O golpe de 2016 e a facada de 2018 mudou o rumo da nação brasileira dentro e fora do país, impactando nos encontros e nas gestões da ABEH.

O VIII Congresso Internacional da Associação Brasileira de Estudos da Homocultura, que aconteceu de 23 a 25 de novembro de 2016 na Universidade Federal de Juiz de Fora (UFJF), em Minas Gerais, foi marcado pelas frustações pós-golpe. A preocupação sobre o que podia ou não acontecer era compartilhada por pesquisadores, pesquisadoras e pesquisadories, que estavam conscientes do impacto negativo para a população LGBTQI+ e, consequentemente, para a futura gestão da $A B E H$. A expectativa é que poderíamos encontrar dificuldades ainda maiores, por causa da falta de financiamento para esse tipo de evento. Na versão anterior, realizada em 2014 na Universidade Federal do Rio Grande do Sul (UFRGS), na cidade do Rio Grande, os ânimos eram bem melhores e com expectativas mais favoráveis para a referida população.

Foi nessa ocasião que pensei em me candidatar pela primeira vez a presidência da $A B E H$, mas fui convencida que não era o momento oportuno, pois havia uma candidatura que já era consenso desde o Congresso da ABEH de 2012, que aconteceu na Universidade Federal da Bahia (UFBA), em Salvador. Manifestei publicamente o interesse em ser candidata em 2016 e fui incluída na nova gestão como integrante do Conselho Fiscal, pois esta era uma prática adotada para a preparação de quem pretendia disputar a presidência. A participação na Diretoria era uma forma de conhecer a Associação e propor a continuação ou a criação de novos projetos.

O Congresso de Juiz de Fora, em 2016, aconteceu em um clima diferente. Como a conjuntura nacional não era a mesma ouvi vários conselhos para desistir da candidatura. O argumento dos "conselheiros" e das "conselheiras" era que seriam anos dificeis para a população LGBTI+, que a gestão corria o risco de ter um evento esvaziado de pessoas e produção de conhecimento ou de nem conseguir realiza-lo. Refleti muito sobre os perigos desta decisão, mas lembrei de todas as dificuldades que passei na vida, a situação de pobreza, a expulsão de casa, a dificuldade para ser estudante travesti na escola e na Universidade, a entrada no mundo do trabalho, a especialização, a aprovação no mestrado, a alegria e a tristeza de ter sido a primeira travesti a concluir o doutorado em uma Universidade Pública do Brasil e a passar no 
concurso de uma universidade federal ${ }^{9}$. Todas estas lembranças, juntamente com o apoio de parte dos colegas e das colegas, me ajudaram a superar os temores e os conselhos negativos que ouvi, possibilitando a manutenção da candidatura e a apresentação de um plano de gestão.

A aprovação da nova diretoria veio acompanhada por grandes desafios. Assim com o aconteceu em várias outras ocasiões precisei superar a descrença por parte de algumas pessoas que duvidavam da capacidade das travestis, reproduzindo a transfobia estrutural que existe fora e dentro do meio LGBTQI+. A equipe ${ }^{10}$ de gestão, composta por pessoas qualificadas, evitou criar hierarquias entre diretoria e conselho consultivo. Assumimos as responsabilidades específicas sem deixar de manter o mesmo poder de voz e voto nas tomadas de decisões, criando um grupo de whatsapp para possibilitar a integração e participação horizontal, fazendo as conversas virtuais e os encontros presenciais com base nos princípios de uma gestão democrática ${ }^{11}$.

O tema que escolhemos para o IX CINABEH foi "Diversidade Sexual, Gênero e Raça: Diálogos Brasil-África”, em sintonia com o trabalho de integração da UNILAB. O objetivo era promover e ampliar os saberes através da interseccionalidade entre gênero, orientação sexual e raça. $O$ evento seria realizado na sede da Universidade da Integração Internacional da Lusofonia Afro-brasileira, na cidade de Redenção (CE). Mas, logo percebemos que o campus da Liberdade não tinha estrutura para receber um evento com um número tão elevado de participantes. A solução foi transferir para a Universidade Federal do Ceará, em Fortaleza, facilitando o trabalho da

\footnotetext{
${ }^{9}$ Ainda em 2005 lecionei na Universidade Estadual do Rio Grande do Norte, mas apenas em 2013 fui aprovada no concurso público para docente da Universidade da Integração Internacional da Lusofonia Afro-Brasileira (UNILAB). Como o contrato era de dedicação exclusive tive que pedir exoneração da função de professora efetiva do município de Morada Nova - CE (onde atuei desde 1997) e do Estado do Ceará ( onde atuei desde 2003). Neste período também assumi cargo de gestão na coordenação pedagógica e também na superintendência de 26 escolas estaduais distribuídas em 13 municípios do Estado Ceará.

${ }^{10}$ Alfrâncio Ferreira Dias (UFS) - Primeiro Secretário Executivo; Marcos Lopes de Souza ( UESB) Segundo Secretário; Carlos Eduardo de Oliveira Bezerra (UNILAB) - Primeiro Secretário Financeiro; Amana Matos (UERJ) - Segunda Secretária Financeira. CONSELHO CONSULTIVO E FISCAL: Anderson Ferrari (UFJF); Felipe Bruno Martins Fernandes ( UFBA); Fátima Lima ( UFRJ); Alexsandro Rodrigues (UFES) e Wilton Garcia ( USP).

${ }^{11}$ Além de ter experiência em gestão, tive formação específica pela UFJF e lecionava disciplinas de gestão na UNILAB.
} 
equipe organizadora e o deslocamento das/os participantes. O período definido para fazer o Congresso foi de 28 a 30 de novembro de 2018. Como o tema já tinha sido aprovado buscamos uma artista da comunidade LGBTQI+ para expressar visualmente essa proposta, como vemos imagem abaixo:

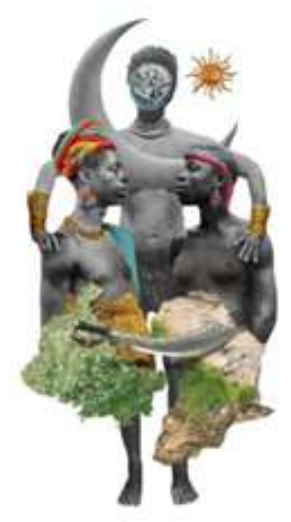

Figura 1: Arte principal do IX Congresso Internacional da ABEH.

A arte foi construída por Elisa Riemer, que compreendeu a proposta do evento e atendeu as sugestões do núcleo gestor da $\mathrm{ABEH}$. As pessoas negras representavam a diversidade sexual do Brasil e do continente africano, que carregavam na cabeça e nas orelhas as cores das bandeiras LGBT e trans. Os dois mapas formavam algo semelhante ao yin/yang, colocando o Brasil "de cabeça para baixo" para simbolizar o golpe de 2016 e as consequências para a população LGBTQI+. A entidade Gaia, que representa a Unidade, a união entre os povos promove a integração com as energias do sol e da lua. $\mathrm{Na}$ parte inferior atravessando os mapas do Brasil e Continente Africano ainda existe uma ponte de elo e proteção representada pela espada de ogum que demarca também a resistência e a luta da população negra e LGBTQI+ nos dois continentes.

Superado o desafio de criação do tema e da arte, percebemos que deveríamos encontrar uma forma de facilitar a divulgação, pois o nome IX Congresso Internacional da ABEH era longo demais. Para sintetizar colocamos na logomarca com a sigla IX CINABEH, incluindo também o significado para facilitar a assimilação: 


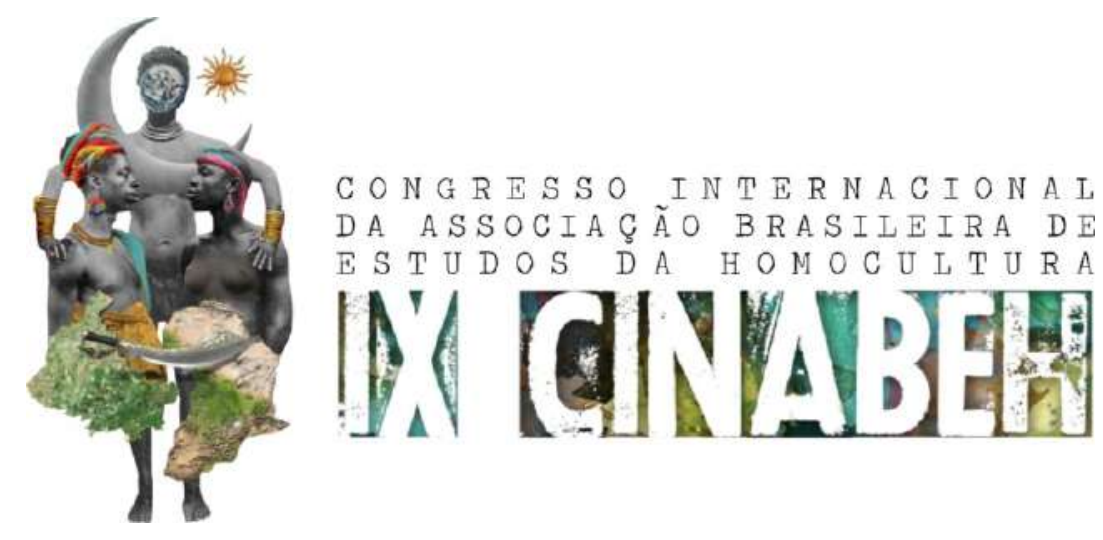

Figura 2: Logomarca do IX CINABEH

O evento foi sendo desenhado através do tema, das artes e do projeto, que viabilizou a capitação de recursos junto a instituições de fomento e outras/os apoiadoras/es. Em meio a dificuldade de buscar apoio em um governo que estava realizando cortes de recursos resolvi buscar financiamento de todas as formas possíveis. Quando fui escolhida para representar a $\mathrm{ABEH}$ no Conselho Nacional de Combate à Discriminação LGBT (CNCD-LGBT), que está diretamente ligado ao Ministério de Direitos Humanos, estabeleci os primeiros contatos com futuras parcerias como a Organização das Nações Unidas (ONU), departamento de DST/AIDS do Ministério da Saúde, SEPPIR e parlamentares dos partidos da esquerda. A cada reunião do CNCD-LGBT realizada em Brasília reservei alguns momentos para apresentar a $\mathrm{ABEH}$ e o projeto do evento, conquistando aliadas/ os relevantes para o desenvolvimento do trabalho. Necessitava de uma quantidade boa de recurso para realizar o maior número de ações possíveis, pois entendia que os esforços da $\mathrm{ABEH}$, em um momento histórico como este, não poderiam se limitar apenas ao Congresso Internacional.

O trabalho começou bem antes, quando fizemos encontros com pesquisadoras e pesquisadores em gênero e diversidade sexual com grupos de pesquisas nas universidades federais, estaduais, particulares e Instituto Federal do Ceará. A intensão não era apenas divulgar o IX CINABEH, era debater a situação que estávamos vivendo depois do golpe de 2016 e do crescimento da extrema direita em 2017 e 2018. Foi pensando nessa conjuntura e no tema central que entramos em contato com representantes dos grupos de pesquisas sobre gênero e sexualidades e com as lideranças 
dos movimentos sociais, realizando pequenos encontros, que serviam para denunciar o momento histórico e divulgar o Congresso Internacional da ABEH.

Os eventos aconteceram na Universidade Federal do Ceará e da Universidade Estadual do Ceará, em Fortaleza; na Faculdade de Filosofia Dom Aureliano Matos, em Limoeiro do Norte; na Universidade Regional do Cariri, no Crato; na Universidade Federal do Cariri, em Juazeiro do Norte; na Universidade Estadual Vale do Acaraú, em Sobral, e na UNILAB, em Redenção, percorrendo universidades da região metropolitana, do Vale do Jaguaribe, do Cariri, do Vale do Acaraú e do Maciço de Baturité. Essa articulação nas universidades e nos movimentos sociais da capital e do interior foi uma das grandes contribuições da ABEH para o Ceará.

Além desta mobilização, apoiamos um evento de abrangência nacional no Campus da Liberdade, em Redenção. $\mathrm{O} 2^{\circ}$ Encontro Nacional de Negras e Negros LGBT, apelidado de Pré-CINABEH, aconteceu de 23 a 25 de novembro de 2018 com o tema "Por um país livre de racismo e LGBTFOBIA", em alusão ao Dia da Consciência Negra, que tinha sido comemorado em 20 de novembro. Como esse Encontro Nacional foi criado pelo CNCD-LGBT, conselho do qual eu fazia parte, participei do debate para a definição da data e local, apresentando a proposta que fosse na UNILAB com o apoio da ABEH e em data próxima ao IX CINABEH, possibilitando a permanência das/ os participantes ${ }^{12}$ no Estado para participar do Congresso Internacional. $O$ presidente do Conselho apresentou outra proposta, mas foi voto vencido pela maioria das/os presentes. 0 resultado potencializou ainda mais nosso trabalho, integrando a comunidade acadêmica aos movimentos sociais numa época que sucede a eleição de 2018. Nós sabíamos que o novo presidente, que sempre atacou a população negra e LGBTQI+, trabalharia para promover retrocessos em nossas conquistas.

O IX CINABEH, que aconteceu três dias depois das atividades do préCINABEH, foi evento brasileiro que mais conseguiu reunir pesquisadoras/ es e lideranças dos movimentos sociais negros e LGBT após a eleição de Bolsonaro. Ele foi fundamental para imaginar estratégias de fortalecimento e táticas de resistência. Na programação contamos com palestrantes internacionais, como Awino Okech (Queniana residente na Inglaterra), Dario Filomeno (Moçambique), Jota Mombaça (brasileiro residente em Portugal),

${ }^{12}$ Lideranças nacionais do movimento negro e LGBT e os/as integrantes do CNCD/LGBT. 
Ludovic Mohamed (França), Ola Osifo Osaze (Queniano nos EUA), Samory Samy (Cabo Verde), Thamy Claude (França) e Ricardo José Santos (EUA) assim como as/os palestrantes brasileiros Ângela Figueiredo, Denilson Lima Santos, Geisa Ferreira do Nascimento, Heráclito dos Santos Barbosa, Jaqueline Gomes de Jesus, João Henrique Machado, Kaciano Barbosa Gadelha, Marina Reidel, Megg Rayara Gomes de Oliveira, Michelle Regina Ferreira e Tatiana Lionço possibilitaram momentos de disseminação de saberes empoderadores para os futuros desafios à população negra e LGBTQI+.

O IX CINABEH foi dividido em dois momentos. O primeiro, das 8:00 as 18:00hs, aconteceu no Campus da UFC e contou com várias mesas de debate, apresentações de simpósios temáticos, pôsteres, lançamento de livros, performances artísticas e exposições, além do cine cuir. O segundo, das 20:00 as 23:00hs, ocorreu no Centro de Arte e Cultura Dragão do Mar de Fortaleza e foi intitulada "Noite Preta Cuirtural". As atividades noturnas iniciaram com a Mesa e a Conferência de abertura, que foram substituídas, no segundo dia, por uma palestra, e no terceiro, pela conferência final. Todas essas atividades acadêmicas foram sucedidas por apresentações artísticas culturais em todas as noites do evento.

A logística de deslocamento nos rendeu algumas preocupações, o único espaço tinha condições adequadas para receber o número de pessoas inscritas era o Centro de Convivência da UFC e o Instituto de Cultura e Arte (ICA), que ficam no Campus do Pici da Universidade Federal do Ceará. A intenção era disponibilizar alojamento digno para as/os estudantes e lideranças de movimentos sociais que não tinham condições de pagar hospedagem e disponibilizar a estas/es acesso a alimentação no restaurante universitário igual aos estudantes da referida universidade. A noite queríamos possibilitar às/aos participantes uma inserção na "Noite Preta Cuirtural" e o local perfeito deveria ter relação direta com a temática do evento. $O$ Centro de Arte e Cultura Dragão do Mar, equipamento cultural da Secretaria de Cultura do Estado, carrega no nome de Francisco José do Nascimento, que passou a ser conhecido como Dragão do Mar por causa da revolta dos Jangadeiros contra o tráfico inter-regional de pessoas negras escravizadas.

Além dessa referência histórica, que é muito simbólica para nós, precisávamos de um local animado, capaz de nos tirar do isolamento das atividades acadêmicas e nos levar para o centro da cidade, no meio da vida noturna da capital cearense. $O$ local atendia a esse perfil porque 
tinha exposições de artes, áreas de lazer, praças de alimentação e boates direcionadas ao público LGBTQI+, além de ser próximo a praias de Iracema e ao calçadão da Beira Mar. Para facilitar o deslocamento das/os estudantes alojadas/os no Centro de Convivência da UFC disponibilizamos ônibus nos três dias, fazendo a ida e a volta.

Todo este trabalho, minuciosamente planejado pela gestão da $A B E H$, era necessário para possibilitar o maior número possível de pessoas no Centro de Arte e Cultura Dragão do Mar, evitando acidentes no deslocamento e coibindo a violência e o preconceito, que tinham se tornado ainda mais comum nos meses que antecederam e sucederam as eleições presidenciais de 2018. Nós tínhamos a percepção que o biênio da gestão da ABEH, entre o Golpe de 2016 e a facada de 2018, tinha sido violento, mas quando olhamos para o gráfico abaixo percebemos que a nossa preocupação era necessária, estávamos vivendo o período mais violento das últimas décadas para à população LGBTTQI+ que vive no Brasil, como mostra o relatório de mortes violentas de LGBT no Brasil que foi feito em $2019^{13}$ pelo Grupo Gay da Bahia (GGB):

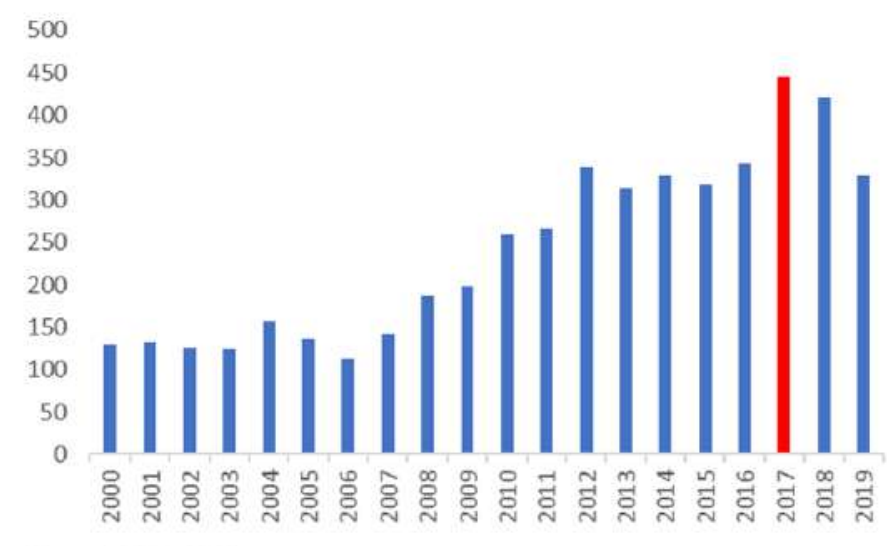

Fonte: GGB, 2019.

Gráfico 1: Mortes violentas de LGBT+ no Brasil, 2000 - 2019

${ }^{13}$ OLIVEIRA, José Marcelo Domingos de; MOTT, Luiz. Mortes violentas de LGBT+ no Brasil 2019: Relatório do Grupo Gay da Bahia. 1. ed. Salvador: Editora Grupo Gay da Bahia, 2020. Disponível em: https://grupogaydabahia.com.br/relatorios-anuais-demorte-de-lgbti/. Acesso em: $29 / 11 / 2020$. 
Analisando o gráfico é possível identificar que 2017 foi o ano com maior número de mortes (445), superando em 102 casos o ano de 2016 que tinha registrado 343 casos. De 2016 para 2017 o número de mortes foi ampliado em $35 \%$, que é o maior aumento registrado de um ano para o outro na série apresentada de 2000 a 2019. Em 2018 teve uma diminuição de 25 casos em relação ao número registrado, ou seja 5,6\%, registrando 420 mortes. Mas, apesar da queda, ainda temos um número alto quando comparado com os dados de 2016, existe um aumento de 77 mortes que equivale a $22,4 \%$. Os anos de 2017 e 2018 trouxeram, respectivamente, o maior número de mortes violentas cometidas contra a população LGBT+.

A nossa preocupação com as/os participantes se torna ainda mais justificável quando analisamos o dossiê dos assassinatos e da violência contra travestis e transexuais brasileiras/os de 2019, organizado e disponibilizado pela Associação Nacional de Travestis e Transexuais (ANTRA). O biênio se destaca, de maneira negativa, quando analisamos o número de assassinatos registrados no Brasil de 2008 a $2019^{14}$.

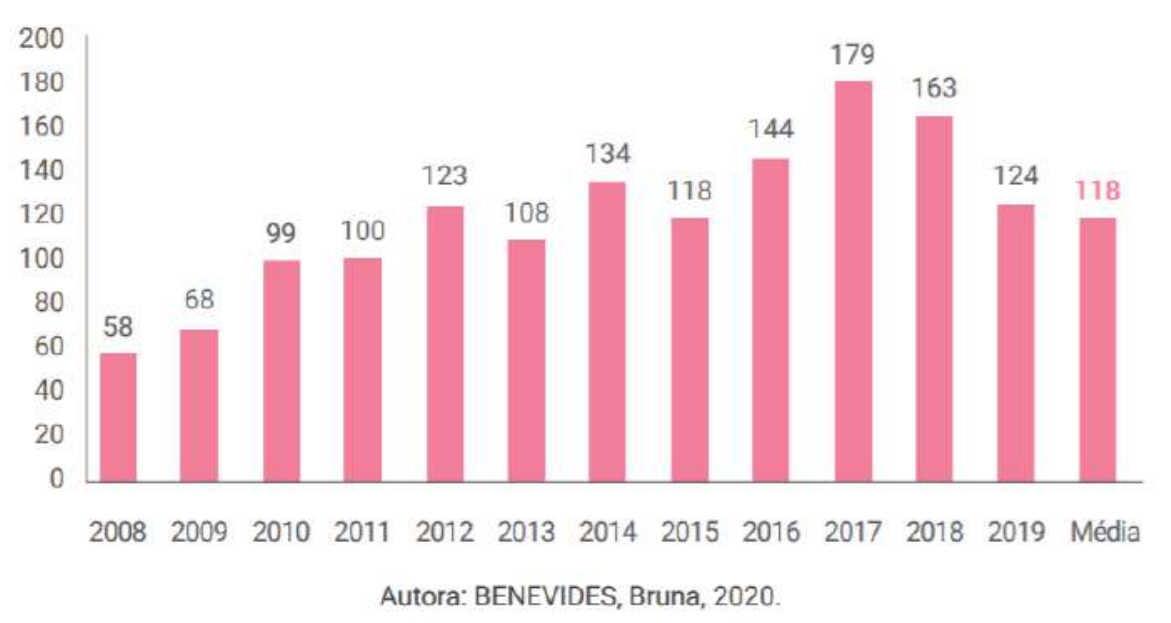

Gráfico 2: Dados dos Assassinatos de pessoas trans no Brasil entre 2008 e 2019

\footnotetext{
${ }^{14}$ BENEVIDES, B. G; NOGUEIRA, S. N. B. (Orgs.). Dossiê dos assassinatos e da violência contra travestis e transexuais brasileiras em 2019. São Paulo: Expressão Popular, ANTRA, IBTE, 2020. Disponível em: https://antrabrasil.files.wordpress.com/2020/01/dossic3aa-dos-assassinatos-e-daviolc3aanciacontra-pessoas-trans-em-2019.pdf . Acesso em 29/11/2020.
} 
O ano de 2017, como podemos perceber, teve o maior número de assassinatos (179), superando em 35 casos o ano de 2016 que tinha registrado 144 vítimas. É relevante destacar que de 2016 para 2017 o número de mortes foi ampliado em 19,5\%, sendo o maior aumento registrado de um ano para o outro na série apresentada de 2008 a 2019. Em 2018 foram registrados 163 assassinatos, ocorrendo uma diminuição em relação ao número identificado em 2017 de 16 vítimas (8,9\%). Mas, quando comparamos com os dados de 2016 percebemos que aconteceu o inverso, um aumento de 19 assassinatos, (13,2 \%). O biênio de 2017-1018, que equivale a gestão da primeira professora e pesquisadora travesti na presidência da $\mathrm{ABEH}$, foi acompanhada por mudanças estruturais que reforçam o preconceito e a discriminação, provocando uma onda de violência que aumentou ainda mais o número de assassinatos de pessoas trans no Brasil.

Ao comparar os dois gráficos percebemos que existe uma semelhança, apesar dos números serem diferentes sobem e descem de uma maneira que produzem quase o mesmo movimento. Em ambos, encontramos um aumento acentuado de mortes/assassinatos em 2017 e uma diminuição no ano seguinte. Mas, apesar da queda, os dados de mortos de 2018 permanecem superior aos de 2016. 0 ano de 2017 ficou entre dois marcos relevantes de análise o golpe de 2016 e as eleições de 2018, no primeiro temos deputados e senadores destituindo de maneira arbitrária uma presidenta da República, no segundo vemos o acirramento entre forças progressistas e conservadoras em torno da Câmara e do Senado Federal, dos governos Estaduais e do Governo Federal. O Golpe de 2016 não foi apenas contra a presidenta Dilma, ele atingiu as mulheres, os pobres e a população LGBTQIA+, ele foi articulado contra os movimentos sociais, para acabar com os direitos conquistados nas últimas décadas e até nos últimos séculos.

O biênio 2017/2018 não é apenas resultado do Golpe de 2016, o Golpe de 2016 é que é uma reação contra a existência de projetos sociais. $O$ alvo nunca foi apenas Dilma, era a legislação trabalhista e ambiental, os Direitos Humanos, os povos indígenas e quilombolas, a luta dos Movimentos Negros, feministas e LGBTs. Não podemos analisar o que aconteceu em 2017 e 2018 olhando apenas para 2016, nem mesmo para as últimas décadas do século XXI, porque ele é resultado de uma história de curta, média e longa duração. $O$ ataque veio acompanhado por um fascínio, até então escondido, pelos porões da Ditadura Civil-Militar, do Império e da Colonização. A paixão por Ustra, a capacidade de flertar com sujeitos inquisitoriais, escravagistas, 
fascistas e ditatoriais, o desejo de teocracia, de catequese estatal, não é resultado apenas do novo milênio, é uma ressonância de séculos, que ganha espaço e visibilidade com o Golpe de 2016 e a eleição de 2018.

A escolha de um tema sobre Brasil, África, raça, gênero e sexualidade não foi por acaso, os ataques que faziam à população LGBTQI+, a população negra e as religiões de matrizes africanas estavam sendo intensificados $\mathrm{e}$ expostos. A estrutura de mobilização política e de fakenews montada através do Facebook, do WhatsApp e do Twitter, permitiu dois fenômenos diferentes, que as pessoas atacassem sem mostrar o rosto, através de perfis falsos ou de robôs, ou que absolvessem esse arsenal bélico para compor a subjetividade, mostrando a cara e saindo do "armário" com toda a sua carga de ignorância. Tanto o Golpe de 2016 como a eleição de 2018 se beneficiaram dessas duas faces, a do ódio propagado de maneira planejada e anônima na web e na deep web, e a do ódio descarado, cuspido na tela e escarrado nas ruas, com orgulho de ser politicamente incorreto. Uma parte da sociedade brasileira resolveu surfar no pico dessa onda, externando de forma explícita seu ódio, como vemos nas situações abaixo:

1) Dandara dos Santos foi assassinada em 15 de fevereiro de 2017 em Fortaleza e a sua morte repercutiu no Brasil e no mundo porque os assassinos gravaram a cena, mostrando no You Tube e nas redes sociais um dos casos mais violentos contra pessoas travestis e transexuais. "A gravação tem 1 minuto e 20 segundos e termina quando os suspeitos colocam a vítima no carrinho de mão, após agressões com chutes, chineladas, pedaços de madeira, e descem a rua." Após as agressões Dandara foi atingida a bala e veio a óbito. (http://g1.globo.com/ceara/ noticia/2017/03/apos-agressao-dandara-foi-morta-com-tiro-dizsecretario-andre-costa.html)

2) A Exposição Queermuseu - Cartografias da Diferença na Arte Brasileira, que estava presente no Santander Cultural de Porto Alegre, foi cancelada em setembro de 2017 por causa dos protestos dos fundamentalistas religiosos e conservadores (https://brasil.elpais.com/ brasil/2017/09/11/politica/1505164425_555164.html) 
3) Terreiros religiosos de matrizes africanas foram atacados em 2017 por integrantes de facções criminosas que faziam uso de armas de fogo para invadir o espaço e obrigar as mães e os pais de santos a destruírem símbolos religiosos. Os invasores proferiam xingamentos, ameaças e quebravam as guias dos presentes usando jargões de cultos cristãos. https://cbn.globoradio.globo.com/editorias/policia/2017/09/13/ CRIMINOSOS-OBRIGAM-MAE-DE-SANTO-A-DESTRUIR-PROPRIOTERREIRO-EM-NOVA-IGUACU.htm)

4) Ataque a Judith Butler. A presença da filósofa no seminário "Os Fins da Democracia" que aconteceu no SESC Pompeia em São Paulo em 07 de novembro de 2017, provocou manifestação contrária de pessoas alinhadas ao "Escola sem Partido", que queimaram uma boneca simbolizando a convidada como bruxa, uma referência direta a inquisição. No dia 10 de novembro de 2017 quando ela estava com sua companheira no aeroporto de Congonhas para retornar para o seu país foi alvo de agressões verbais por uma mulher que carregava uma placa que constava "Fora Judith". O caso acabou na delegacia e foi registrado como injúria. (https://g1.globo.com/sao-paulo/noticia/filosofa-judithbutler-e-alvo-de-ofensas-em-aeroporto-de-sp-e-mulher-e-agredidaao-defende-la.ghtml)

Estas são algumas das matérias que revelam uma mudança na sociedade brasileira causada pelo avanço de um ideal conservador que não respeita a diversidade, que tenta moldar o mundo a sua visão e interesse. 0 biênio 2017-2018 é um novo momento de "caça às bruxas", de perseguição as diferenças, liderado por uma parte das elites políticas, dos grupos religiosos, que desejavam a tomada do Estado a qualquer custo. 0 golpe de 2016 se apresentou como uma vitória e fortalecimento de seus ideais, preparando terreno para a violência e as mortes de 2017 e as eleições de 2018. A queda de Dilma simbolizava um universo de possibilidades para os políticos do centro e da direita, que apoiaram Jair Bolsonaro quando perceberam que ele podia ganhar.

A máscara do liberalismo, da civilidade, da humanidade caiu. Os políticos assumiram a sua face absolutista, soberana e desumana, apoiando a família Bolsonaro em nome dos interesses econômicos e sociais. $O$ governo que se 
diz neoliberal na economia e conservador nos costumes, mistura promessas de flexibilização e estado mínimo com autoritarismo e nacionalismo de fachada. Ao criar uma nova teocracia, regida por uma espécie de catequese estatal, que cultua o Deus do Mercado e da bancada religiosa, criando um cenário de precarização.

Até mesmo as pessoas que pareciam aliadas começaram a assumir esses discursos, contrariando a própria história de vida. Uma ex-madrinha de uma parada gay, por exemplo, passou a disseminar discursos de ódio contra travestis e transexuais nas redes sociais e um ex-gogo boy de boates gays que tinha sido contratado para ser streeper em uma Parada pediu para apagar os registros dessa última atividade nas redes sociais. Como não foi atendido, chegou a ameaçar a organização do evento para que retirassem o vídeo. A alegação é que tinha mudado de vida, que era casado, pai de família e policial, que estava sofrendo bullying dos colegas por ter participado de uma "parada gay". Essa solicitação, que parece individual, demonstra que a LGBTfobia era estrutural e que as mudanças políticas de 2016, 2017 e 2018 mexeram com essas estruturas, para pior.

O desespero do Gogo Boy para apagar ou eliminar registros de seu passado, estava diretamente ligado à conjuntura nacional. Ele estava apoiando as forças conservadoras da extrema direita e defendia Jair Bolsonaro. A mesma coisa aconteceu nas universidades, professores e professoras, que tinham um discurso em defesa da diversidade, se renderam à conveniência dos cargos de gestão, externalizando os discursos que estavam internalizados, esperando a oportunidade certa para ganhar vantagens. A interferência do Governo Federal no ensino universitário, a criminalização das instituições acadêmicas, dos estudantes e dos professores, criaram novas relações de poder, onde ex-aliados aparecem sem máscaras, ou com a face do presidente e do ministro da educação. Essa é a única coisa positiva que resultou do Golpe de 2016 e da facada de 2018, aprendemos a ver os golpes e as facadas que acontecem do nosso lado, conseguimos entender como realmente pensam, ver através dos olhos, dos gestos e dos atos o veneno que estava acumulado. Eliminam seus obstáculos e utilizam estes como degraus para conseguir a ascensão ao "poder" que, em outra conjuntura, seriam incapazes de alcançar.

Assumimos a gestão da $\mathrm{ABEH}$ no meio desse turbilhão de acontecimentos e temíamos novos ataques. Foram dias e noites angustiantes, que exigiam 
um investimento maior na segurança do Encontro. Mas, estávamos na região Nordeste, em um estado onde a maioria da população criticou o Golpe de 2016 e votou contra Bolsonaro. O Governo do Ceará e a Prefeitura de Fortaleza eram de partidos de esquerda e estavam apoiando o evento. Mas, além de se proteger das ameaças precisávamos fazer o contrário, ver o próprio evento enquanto ameaça, como campo de resistência. Todas as atividades realizadas em 2017 e 2018 na capital e no interior traziam esse sentimento de denúncia e esperança.

o Congresso internacional contextualizou o crescimento da estrema direita no mundo e o impacto sobre as populações historicamente excluídas, mostrando a necessidade de um pensamento interseccional, que vá além das barreiras geográficas e das fronteiras acadêmicas, aproximando Brasil e África, Europa e África, EUA e África, América do Norte e América Latina para discutir de maneira indissociável raça, gênero e sexualidade. Mas, não se tratava apenas de falar sobre a temática, a proposta era colocar os pesquisadores negros e as pesquisadoras negras nas mesas e nas conferências, os pesquisadores e as pesquisadoras LGBTs, as lésbicas, os gays, as mulheres travestis e transexuais, na linha de frente do conhecimento científico.

Essa preocupação com os corpos e as pesquisas dissidentes começaram antes e continuariam depois do Congresso Internacional. A equipe gestora da ABEH 2017-2018 foi responsável pela criação da Revista Brasileira de Estudo da Homocultura - REBEH e do prêmio ABEH de dissertação e teses, além atuar ativamente para captação de recursos da união e do parlamento. Em meio a defesa das políticas afirmativas, a Associação criou uma campanha de filiação e realizou reuniões presenciais da $A B E H$ dentro dos eventos nacionais e internacionais. Publicamos notas, manifestações e ações no CNCD/LGBT, realizando debates e enquetes pela tentativa da criação de uma sub-área na CAPES de gênero e sexualidade.

1 - A REBEH ${ }^{15}$, que carrega o ISSN 2595-3206, foi gestada e planejada em 2017, tendo como editoras chefes eu e a Profa. Dra. Bruna Irineu (atual presidenta da $A B E H)$. $O$ desafio não era apenas de criar a revista, mas manter da melhor maneira possível para que os trabalhos não sejam interrompidos posteriormente. Não foi fácil manter esse projeto, mas superamos os

\footnotetext{
${ }^{15}$ Revistas disponíveis em: https://periodicoscientificos.ufmt.br/ojs/index.php/rebeh/index
} 
desafios e surpreendemos a muitas/os que pensavam que ficaríamos apenas no primeiro número. Publicamos os quatro primeiros volumes e na primeira avaliação da CAPES obtivemos avaliação B1. Após a conquista do status qualis da CAPES, a revista passou a ter maior visibilidade e procura por quem desejava fazer publicação. Entregamos para a nova gestão da ABEH um produto relevante e, aos cuidados da gestão atual, a revista continua sendo muito bem conduzida.

2 - O Prêmio ABEH de dissertação e tese ${ }^{16}$ foi criado para motivar a produção e premiar dissertações e teses com foco em diversidade sexual e gênero. Esta iniciativa considero como uma forma de reação também ao que vivi no passado, quando a tese produzida por uma travesti sobre pessoas travestis e transsexuais na escola não poderia se quer ter a possibilidade de ser avaliada a nível local para o prêmio CAPES de teses. 0 tempo era outra, a temática e a autora era sempre posta sob suspeita, mas anos depois com uma melhor abertura o estudo foi reconhecido e fundamentou, inclusive, relevantes conquistas para a população de travestis e transexuais, a exemplo da aprovação do reconhecimento do nome social a travestis e transexuais através de portaria deliberada pelo MEC em 2017. Fui convocada para fazer a defesa da referida portaria usando inclusive a citada tese no Conselho Nacional de Educação e este aprovou por unanimidade a mencionada portaria e encaminhou para deliberação do Ministro da Educação. Outro grande prêmio que recebi que não foi o da CAPES tese foi o de ter contribuído para a mudança de paradigma em relação às pessoas travestis e transexuais, pois fui apenas a primeira doutora travesti e docente universitária travesti do Brasil a viver este percurso desde a educação básica como travesti e como sempre sentia que em nenhuma das etapas os espaços estavam preparados para minha presença/existência e esse caminho tive que fazer em anos duros de incompreensão sobre minha singularidade. Apesar disso, me conforta saber que, mesmo sendo em outro momento da história, com maior compreensão e dispositivos legais favoráveis, outras travestis e transexuais que vieram depois tiveram a oportunidade de suas dissertações e teses serem pelo menos avaliadas, sem distinções, para possível indicação de suas universidades ao prêmio CAPES de dissertação e teses. Assim, vimos

${ }^{16} \mathrm{O}$ edital do prêmio também foi publicado em: http://www.revistas.unilab.edu.br/index.php/ rebeh/article/view/119/76 
no I Prêmio ABEH de dissertação e tese ${ }^{17}$ uma outra possibilidade de premiar trabalhos potentes sobre a temática e não ficar à mercê do Prêmio CAPES, que pode sofrer a influência do conservadorismo.

3 - Reuniões presenciais da ABEH em eventos foi uma tática importante para alinhar as ideias e divulgar nossas ações, além de interagir com nossos pares sobre as questões atuais. A primeira foi no $13^{\circ}$ Mundos de Mulheres $/ 11^{\circ}$ Fazendo Gênero, ocorrido em 30 de julho a 4 de agosto de 2017 na Universidade Federal de Santa Catarina (UFSC) em Florianópolis, a segunda foi no V Seminário Internacional Enlaçando Sexualidades realizado de 06 a 08 de setembro de 2017 na Universidade Estadual da Bahia e a terceira no III Seminário Internacional Desfazendo Gênero ocorrido de 10 a 13 de outubro de 2017 na Universidade Estadual da Paraíba em Campina Grande. Nesta última, realizamos o lançamento oficial do IX CINABEH, em momento específico para esta finalidade.

\section{4 - Publicação de notas, manifestações e ações do CNCD/LGBT na} REBEH e site do IX CINABEH como forma de publicizar o trabalho realizado e manifestar posicionamento a ataques deflagrados a população LGBTQI+ como: Nota de repúdio N. 001/2017 (02/03/2017) ao assassinato de Dandara dos Santos ${ }^{18}$; Nota de repúdio N.002/2017 (19/09/2017) ao juiz federal Dr. Waldemar Cláudio de Carvalho pela suspensão da Resolução 001/1999 do Conselho Federal de Psicologia ( CFP) ${ }^{19}$; Nota de apoio de 02/11/2018 a vinda de Judith Bautler ao Brasil ${ }^{20}$; Relatório de gestão do período de 2016 e 2017 da ABEH no CNCD/LGBT ${ }^{21}$; Relatório do IX CINABEH ${ }^{22}$

5- Captar recursos da união era uma forma de garantir ao IX CINABEH as condições necessárias para o desenvolvimento das ações e um dos primeiros obstáculos foi encontrar forma de conseguir tais recursos. Estávamos vivendo momentos de ataque aos recursos destinados as universidades e o discurso do Estado Mínimo e da crise financeira era utilizado para cortar

\footnotetext{
${ }^{17}$ Resultado do I Prêmio ABEH de dissertações e teses: http://www.congressoabeh.com.br/pdf/ RESULTADOS_0712201817115c0ac5e807bb4.pdf

${ }^{18}$ Nota disponível em: https://periodicoscientificos.ufmt.br/ojs/index.php/rebeh/article/view/9079

${ }^{19}$ Nota disponível em: https://periodicoscientificos.ufmt.br/ojs/index.php/rebeh/article/view/9081

${ }^{20}$ Nota disponível em: https://periodicoscientificos.ufmt.br/ojs/index.php/rebeh/article/view/9080

${ }^{21}$ Relatório disponível em: https://periodicoscientificos.ufmt.br/ojs/index.php/rebeh/article/ view/9083

${ }^{22}$ Relatório disponível em: http://www.revistas.unilab.edu.br/index.php/rebeh/article/view/224/127
} 
gastos na educação, saúde e outras áreas sociais. A alternativa foi buscar o apoio de deputadas/os da esquerda como do PT e PSOL. Apresentamos o projeto e tentamos apoio através de emendas parlamentares através da deputada Luiziane Lins (PT-CE) e o ex-deputado Jean Wyllis (PSOL-RJ).

A outra frente de atuação foi com a CAPES, onde submetemos um projeto de subsídios a eventos que foi aprovado com valor nunca antes contemplado pela ABEH. Mas, ao buscar a senha do SICONV da ABEH, descobrimos que estava no nome do presidente da gestão 2011-2012 e que nunca tinha feito uso do referido sistema para receber emendas parlamentares. Uma conta bancária institucional foi aberta para receber os recursos captados e fomos a gestão da $\mathrm{ABEH}$ que mais recebeu recursos para o desenvolvimento de suas atividades.

6 - Políticas afirmativas foram implementadas com os recursos aprovados e com isso foi possível disponibilizar isenção da taxa de inscrição e alojamento (com segurança $24 \mathrm{hs} \mathrm{e} \mathrm{limpeza} \mathrm{do} \mathrm{espaço)} \mathrm{para}$ estudantes de baixa renda ou que autodeclarassem não ter condições financeiras. Fornecemos transporte para os deslocamentos entre o Centro de Convivência da UFC e Centro Dragão do Mar durante o evento para quem estava nos alojamentos da ABEH. Um ônibus foi disponibilizado para realizar o translado de estudantes e professores da UFBA e UNILAB-BA com ida e volta de Salvador à Fortaleza. Quem foi para o evento estando inscrito ou não teve acesso livre a todos os espaços de atividades. Cada sala de Simpósio Temático (ST) foi identificada com o nome de uma personalidade integrante da comunidade LGBTQI+ acompanhado de foto e breve histórico contemplando vivos e mortos. As/Os inscritas/os receberam blusa, bolsa, caneta, bloco de anotação e copo plástico do evento. As/Os artistas e grupos que realizaram apresentações para o congresso receberam auxílio financeiro como forma de valorizar suas artes. Estas foram as formas encontradas e possíveis de minimizar o processo de exclusão no IX CINABEH.

\section{7 - A proposta de criação de uma sub-área de gênero e sexualidade} na CAPES era uma um tema recorrente entre pesquisadoras/es da temática e isto foi retomado em uma reunião realizada no $V$ enlaçando, que mencionei anteriormente. Na ocasião fui convidada para uma reunião com foco na integração entre todas/os para superar as dificuldades que estavam ocorrendo e daquelas que estavam por vir. Um dos pontos era a busca pela possível criação da referida sub-área, mas não foi possível deliberar, pois era 
necessário realizar uma consulta mais ampla. Assim, resolvemos criar no site do IX CINABEH uma consulta pública para grupos de pesquisa que envolvem a temática e dos 58 que participaram 94,7 \% aprovaram a busca pela criação na CAPES da criação de uma sub-área de gênero e sexualidade. Divulgamos o resultado e passamos a solicitar oficialmente diálogo na CAPES, mas nossa solicitação nunca foi respondida.

Tentamos realizar nesta gestão da ABEH o máximo e o melhor que podíamos em um momento desafiador que necessitava de nossa intervenção incisiva realizando ações para resistência e finalizando com o maior evento que a instituição já realizou com 2.135 participantes, 1.530 inscritos, 363 trabalhos aprovados, publicação de um e-book ${ }^{23} \mathrm{com} 1.972$ páginas. Como a instituição estava sendo presidida por uma travesti não poderíamos deixar de ter um olhar de inclusão com relação a essa população, era preciso travestilizar e/ou transexualizar a gestão incorporando nos documentos os símbolos as cores da bandeira trans. O Congresso Internacional de 2018 atraiu o maior número de travestis e transexuais que participaram das mesas e dos simpósios temáticos, na condição de docente, discente ou de representante dos Movimentos Sociais. A Mesa de Abertura teve sete travestis e transexuais. O primeiro número da REBEH, escrito apenas por pessoas trans, também pode ser visto como reconhecimento dos pesquisadores $\mathrm{e}$ das pesquisadoras travestis e transexuais.

Todas/os as/os integrantes do núcleo gestor, convidadas/os da ABEH receberam, passagens, hospedagens e diárias, as/os coordenadoras/es de ST também foram contemplados de alguma forma com passagens e/ ou diárias e/ou hospedagem a depender da necessidade que cada uma/ um apresentava. As prestações de contas foram aprovadas e os relatórios apresentados, as despesas administrativas no escritório de contabilidade quitadas, impostos da associação foram pagos, a documentação entregue a presidenta eleita e a $\mathrm{ABEH}$ ainda repassou pela primeira vez recurso em dinheiro para a nova gestão. Em meio a tantos golpes e facadas sangramos, e continuaremos a sangrar por bastante tempo, enfrentando o que há por vir até o sangue estancar, a ferida cicatrizar e a vida ampliar o pulsar sem medo de ser feliz.

${ }^{23}$ E-book disponível em: https://editorarealize.com.br/edicao/ebook/3/detalhes 


\section{REFERÊNCIAS}

ANDRADE, Luma Nogueira. A ABEH: uma história de resistência e de produção do conhecimento. In: GREEN, James. Et. Alli.(org.). História do Movimento LGBT no Brasil. São Paulo: Alameda Editorial, 2019. . 501-514.

BESSONE, T.; MAMIGONIAN, B.G.; MATTOS, H. (Orgs.). Historiadores pela Democracia - o golpe de 2016: a força do passado. São Paulo: Editora Alameda, 2016.

BENEVIDES, Bruna G.; NOGUEIRA, Sayonara Naider Bonfim. (Orgs). 2020. Dossiê dos assassinatos e da violência contra travestis e transexuais brasileiras em 2019. São Paulo: Expressão Popular, ANTRA, IBTE, 2020. Disponível em: https://antrabrasil.files.wordpress. com/2020/01/dossic3aa-dos-assassinatos-e-daviolc3aancia-contra-pessoas-trans-em-2019. pdf. Acesso em 29/11/2020.

OLIVEIRA, José Marcelo Domingos de; MOTT, Luiz. Mortes violentas de LGBT+ no Brasil 2019: Relatório do Grupo Gay da Bahia. 1. ed. Salvador: Editora Grupo Gay da Bahia, 2020. Disponível em: https://grupogaydabahia.com.br/relatorios-anuais-demorte-de-lgbti/. Acesso em: 29/11/2020. 


\title{
GESTÃO DA DIVERSIDADE NO BRASIL: NOTAS CRÍTICAS
}

\author{
Jaqueline Gomes de Jesus
}

Muito se fala acerca da diversidade. Mesmo os discursos mais fundamentalistas e intolerantes se remetem a ela, ou a alguma(s) de suas dimensões. Mas o que é diversidade? Quem a compõem? O que significa a diversidade: é uma identidade? Ou, quem sabe, uma "afinidade"? Uma teoria? Uma prática?

Quanto mais as sociedades se interpenetram, na conjuntura da globalização, mais se pluralizam as diferenças individuais e grupais, ou, no mínimo, as diferenças já existentes se tornam evidentes, quando anteriormente não o eram. A diversidade sempre existiu, e seja ela o que for, é cada vez mais visível.

O termo "diversidade" é oriundo de latim tardio diversificu, "variado", significando diferença, dessemelhança, dissimilitude, divergência, contradição, oposição.

Diversidade e adversidade, palavras de sons semelhantes. Seus sentidos também soam parecidos a uma parte considerável das pessoas. Diante dos impasses conhecidos da vida cotidiana, costuma-se, com frequência, confundir diversidade com um emaranhado de belicosas diferenças, e não é incomum serem fortalecidas ideologias da uniformidade, que promovem o desprezo de determinadas expressões da diversidade humana.

Os significados supracitados são demasiadamente simplórios para abarcar a complexidade do conceito de diversidade, da forma como o aplicamos hoje. A diversidade não se restringe à listagem de seus sinônimos, engloba conceitos antônimos, situações específicas e pessoas concretas.

Cox (1994) define a diversidade como a representação, em um sistema social, de pessoas com diferentes identidades grupais que têm significações 
culturais distintas, ou ainda como um misto de pessoas com identidades grupais diferentes dentro do mesmo sistema social (NKOMO \& COX, 1999).

No contexto das organizações, Buntaine e Johnson (1996) a concebem como a inclusão de pessoas de diferentes culturas, raças, gênero, nacionalidades, estilos e outros atributos. A diversidade é um componente fundamental da identidade social das pessoas, ela é "parte do autoconceito dos indivíduos que deriva do seu conhecimento de pertencimento a um grupo social, associado à significância emocional desse pertencimento" (TAJFEL, 1982, p. 24), de modo que não existe identidade social sem diversidade, uma é indissociável da outra na constituição de quem somos, como seres humanos (ALLPORT, 1954).

A diversidade humana é compreendida, neste trabalho, como "o conjunto de relações interpessoais e intergrupais explícitas ou implícitas, em um determinado sistema social, que são intermediadas pela relação entre as identidades sociais e a dominância social presentes nesse sistema" (JESUS, 2013, p. 224).

Fazendo-se uso da música como metáfora, o trato equilibrado com a diversidade seria uma harmonia, pautada por atitudes de valorização das diferenças no ambiente social; O preconceito e a discriminação seriam como dissonâncias na melodia social, e é com estes dois comportamentos que os gestores da diversidade precisam se preocupar, pesquisando métodos e instrumentos para, de algum modo, superá-los.

A discriminação é um comportamento, o preconceito, uma predisposição a discriminar, fundamentada em estereótipos compartilhadas em um determinado grupo. As manifestações do preconceito - atos discriminatórios -, em suas múltiplas formas, podem ser conscientes ou inconscientes (PÉREZ-NEBRA \& JESUS, 2011).

De acordo com a Constituição Federal de 1988, no título I, capítulo I (Dos direitos e deveres individuais e coletivos), artigo $3^{\circ}$, parágrafo IV, dentre os objetivos fundamentais da República consta: "promover o bem de todos, sem preconceitos de origem, raça, sexo, cor, idade e quaisquer outras formas de discriminação" (BRASIL, 1988; p. 3), enquanto que, no artigo $5^{\circ}$, parágrafo $\mathrm{XLI}$, dos mesmos título e capítulo acima citados, lemos: "a lei punirá qualquer discriminação atentatória dos direitos e liberdades fundamentais” (BRASIL, 1988; p. 8). 
A proposta constitucional de "promover o bem de todos" e de punir "qualquer discriminação" ainda não foi plenamente aplicada em território nacional, tornou-se um mito que instiga as pessoas preocupadas com a realidade a prosseguir lutando até a concretização de seus ideais de igualdade de oportunidades para todos.

O tipo de igualdade idealizado na Carta Magna só pode ser alcançado por meio de uma isonomia verdadeira entre as classes historicamente desprivilegiadas e as privilegiadas, a qual não pode ser alcançada simplesmente por meio de políticas universalistas de apoio, mas como decorrência de ações efetivas e estudadas de incentivo à melhoria das condições dos desfavorecidos, dada a cronicidade da exclusão vigente.

As políticas de ação afirmativa, entre as quais se incluem as reservas de vagas em determinados mercados (cotas), são formas de "discriminação positiva" que se propõem a facilitar acesso de grupos desprivilegiados aos recursos da sociedade. Elas são parte da estratégia que possibilita iniciar uma política de valorização da diversidade, a qual não consegue ser realizada - por razões nem sempre óbvias a todos - sem que a organização em tela seja minimamente heterogênea internamente.

É nessa conjuntura, permeada pela recente implantação de políticas afirmativas para a população negra e outras (SANTOS, 1999; GOMES, 2001; SILVÉRIO, 2002), que a gestão da diversidade, como um campo investigativo e de intervenção nas organizações com o objetivo primordial de fomentar, em um ambiente complexo, a inclusão de pessoas oriundas de diferentes grupos sociais e representativas de identidades sociais diversas (TORRES \& PÉREZ-NEBRA, 2004), pode ser colocada como um mecanismo importante de aprofundamento das oportunidades colocadas pela promoção de complexidade humana em ambientes antes heterogêneos.

\section{Desafios para a Gestão da Diversidade}

Existe a concordância de que as organizações necessitam, neste momento histórico do Brasil e do Mundo, no qual a globalização incorre em maior competitividade entre organizações e demanda maior parceria dentro das instituições, de pessoal capacitado para interagir e gerenciar pessoas um mercado diversificado. 
Essa necessidade é mais percebida em organizações complexas e descentralizadas, que tenham um corpo de integrantes altamente diversificado (sejam eles trabalhadores, em empresas, ou mesmo estudantes, professores (GOMES, 1995) e demais trabalhadores da educação, em escolas), com diversas características pessoais e grupais, que convivem em diferentes contextos interpessoais.

Essa diversidade humana, porém, geralmente não é conhecida em profundidade, por meio de métodos fidedignos, para que se tenha uma ideia de sua heterogeneidade e se possam planejar intervenções que previnam discriminações e promovam a valorização das pessoas.

Quais dimensões da diversidade estão presentes na organização? Onde estão e o que fazem as diferentes pessoas? Há diferenças de tratamento em função do gênero, da cor/raça/etnia, da orientação sexual, da origem geográfica, da idade, da classe sócio-econômica, da deficiência? Quais os impactos pessoais e grupais da discriminação, dentro de uma organização?

Nas escolas, por exemplo, uma parcela significativa dos jovens demonstra uma elevada "intolerância com o que é diferente dos padrões correntes, uma exclusão de qualquer tentativa de compreender a razão do outro, de interagir o diferente a seu ambiente" (JACOBO, 1997, p. 117-119).

No que tange a organizações de trabalho, geralmente se ignora a importância de um diagnóstico da diversidade entre os trabalhadores, para que se tenha a dimensão da sua variedade, identificando-se aspectos a serem melhorados, em prol de sua valorização, e se desenvolvam formas de enfrentar e prevenir os problemas eventualmente detectados.

Estudos como o André (2007) e de Carone e Bento (2002) têm demonstrado o impacto negativo do racismo não apenas na subjetividade, mas também nas relações sociais e profissionais de pessoas negras.

Esses aspectos estão contemplados em temas como: inclusão organizacional, impacto do paradigma de justiça social no estudo de diferenças humanas, importância e reconhecimento da identidade individual nas equipes de trabalho, competência e gerenciamento de diversidade cultural nas organizações.

Incluir grupos sociais diferentes em um espaço antes homogêneo é passo necessário para a valorização da diversidade, porém não é suficiente. Para além do acesso, a gestão dessa diversidade no sentido de que a comunidade a respeite e a agregue a si é importante para que os novos 
atores institucionais sintam-se parte dela, e os estabelecidos os recebam em suas comunidades.

Valorizar a diversidade é um desafio imprescindível a um país que pretende formar cidadãos criativos. Como um indivíduo pode se expressar plenamente se a sua identidade é prejudicada pela exclusão e por conceitos preconceituosos contra ele? O potencial criativo se transforma em atos criativos, redundando em uma revolução cultural, calcada na participação de uma multiplicidade de visões na implementação de um projeto eficaz de país produtivo, amplamente capaz de lidar com as demandas crescentes da globalização.

O maior desafio ao se lidar com os preconceitos acerca da diversidade é ser capaz de propiciar o reconhecimento, o respeito e, preferencialmente, a valorização das diferenças, que passam a ser entendidas e pensadas para além dos estereótipos comezinhos sobre o "outro", os quais tendem a limitar as possibilidades dos indivíduos discriminados na sociedade.

No Brasil, é comum se afirmar a existência, por exemplo, de uma "democracia racial", entretanto, essa não é a realidade encontrada em nossa sociedade, na qual o coletivismo vertical é um padrão cultural típico, o que significa dizer que a desigualdade entre grupos sociais é aceita como normal (TORRES \& DESSEN, 2008).

Em quaisquer organizações brasileiras se nota um contínuo de dominância e discriminação relativo à cor da pele das pessoas: quanto mais escura, maior é a discriminação (LIMA \& VALA, 2004). Situação decorrente de um quadro histórico, que exige, para sua transformação, mudanças estruturais em longo prazo nas desigualdades sócio-raciais, em sintonia "com os anseios das grandes massas de afro-descendentes excluídos e marginalizados" (MOREIRA, 2003, p 63).

No entanto, apesar de haver inúmeras carências no modo de lidar com as questões de diversidade neste país, tanto local quanto nacionalmente, a prática da gestão da diversidade não é disseminada nacionalmente (FLEURY, 2000), sequer valorizada, o que ressoa a prática de se reproduzir modelos estrangeiros de gestão tradicional, que não reconhecem a pluralidade das populações nacionais e o valor de equipes complexas. 


\section{Uma Agenda de Diversidade nas Organizações Brasileiras}

Os grupos e organizações se tornam efetivamente inclusivas, para além de serem diversas, quando adotam perspectivas e enfoques de pessoas com identidades sociais e (THOMAS \& ELY, 2002; COX \& BLAKE, 1991).

Daí porque se pode compreender, como grupos ou organizações que valorizam a Diversidade, aqueles que apresentam, com menor intensidade, conflitos improdutivos entre (e inter) pessoas de origens geográficas, cores/ raças, orientações sexuais, idades, gêneros e habilidades físicas díspares, entre outros; e que mais se aproximam de uma condição em que todos os seus partícipes têm as mesmas oportunidades para o desenvolvimento pleno de suas capacidades.

Por isso, como estratégia de valorização da diversidade nas organizações - quaisquer, tem-se de trabalhar, também, sempre em longo prazo, o senso de coletividade ou de equipe, de modo que ele se torne um "tratamento de choque" em que os preconceitos dos atores organizacionais são desnudados (as pessoas não reconhecem os seus preconceitos como tais), e precisam ser modelados.

Os profissionais em geral devem ter nessa gestão um espaço para se informar e ter alguma formação no que tange às relações interpessoais e intergrupais. No contexto organizacional contemporâneo, essa iniciativa se apresenta como uma oportunidade para que empresas e outras instituições sobrevivam à progressiva competição no mercado de trabalho e na prestação de serviços, o que é primordial em organizações que planejam lançar estratégias de negociação a níveis transnacional e mundial (ADLER \& BOYACIGILLER, 1995; TAPIOLA, 2000).

A variável do engajamento da alta chefia nesse trabalho, sendo deixada à parte, inviabiliza qualquer trabalho que venha a ser desenvolvido com o objetivo de sistematizar e manter processos de gestão da diversidade.

Observando-se os protestos nas ruas, e as manifestações nas redes sociais, apesar de retrocessos no campo político, influenciados fortemente pelo avanço do fundamentalismo religioso e das milícias apoiadas por redes de comunicação, constata-se que a população brasileira, em geral, está se conscientizando, cada vez mais, do espaço e da relevância que os grupos sócio-historicamente discriminados ocupam no contexto das transformações 
contemporâneas no âmbito das relações institucionais, de massa e, até mesmo, globais.

A questão da valorização da diversidade humana nas organizações tem ultrapassado drasticamente os limites das teorias e vem exigindo atuação concreta de certas empresas, mas principalmente dos governos.

Porém, como uma resposta meramente procedimental, a posição do Estado Brasileiro, em particular, tendo sido a de organizar programas pontuais de atendimento ao cidadão, e assumir, como discurso implícito, que o princípio da diversidade é "que as pessoas são diferentes e a sociedade é formada pelo conjunto dessas pessoas" (MINISTÉRIO DO TRABALHO E EMPREGO, 2000, p. 11), acrescentando que considera fundamental "levar em conta (...) a variedade de pessoas e opiniões como vetor principal na concepção do Programa [de ação pela igualdade de oportunidades no trabalho] e na sua execução" (Idem).

Ações governamentais têm-se intensificado, já há algumas décadas, para cumprir a Convenção 111 da Organização Internacional do Trabalho - OIT, a qual define discriminação como "qualquer distinção, exclusão ou preferência (...) que tenha por efeito anular ou alterar a igualdade de oportunidades ou de acesso ao emprego e à ocupação" (ORGANIZAÇÃO INTERNACIONAL DO TRABALHO, 1996).

A fim de implementar as ações propostas no primeiro Programa Nacional de Direitos Humanos - PNDH (Ministério da Justiça, 1998), que já passou por revisões e novas edições, atualizado na forma de programas históricos como o Brasil Sem Homofobia (Secretaria Nacional de Direitos Humanos, 2004) e as Políticas Nacionais oriundas das Conferências Nacionais realizadas principalmente ao longo dos Governos Lula e Dilma, vem-se patrocinando programas e projetos que visam a melhoria nas relações entre os setores sociais, apoiando, especialmente, ações afirmativas pontuais direcionadas a grupos sócio-historicamente discriminados, mas não necessariamente fundamentadas em estratégias de fortalecimento da complexidade organizacional interna, no sentido da formação de equipes de trabalho que se reconheçam como melhores exatamente porque são diversas.

A iniciativa privada tem cada vez mais se envolvido com realizações que se propõem a minorar as discrepâncias sociais, principalmente no que se refere ao emprego e trabalho, no âmbito do conceito de "responsabilidade social", que também têm abrangido a questão ambiental. 
De acordo com Lizuka \& Brincas (1999), as empresas também têm assumido, cada vez mais, o protagonismo quanto serviços voluntários, inclusive avaliando a proatividade de candidatos a recrutamento e seleção a partir de suas experiências pessoais em Organizações Comunitárias ou Organizações Não-Governamentais (ONGs).

A reiteração de comportamentos discriminatórios, durante a implantação de uma política de valorização da diversidade, mais do que significar fracasso, pode, fortemente, indiciar o sucesso da empreitada, a exemplo do que foi relatado pessoalmente a esta pesquisadora, no ano 2001, por uma dirigente da Levi Strauss do Brasil S/A, que ao implantar sua gestão da diversidade no Brasil, encontrou resistências, por apoiar uma política de emprego que valorizava uma força de trabalho diversificada.

No contexto das instituições públicas, pode-se destacar o relato da experiência de gestão da diversidade configurada pela criação da Assessoria de Diversidade e Apoio aos Cotistas da Universidade de Brasília, "uma organização heterogênea, marcada por interesses de diferentes grupos e pelo enfrentamento de preconceitos, de pessoas negras com pessoas negras e não-negras" (JESUS, 2013).

A publicacação de “Homofobia: Identificar e Prevenir" (JESUS, 2014), em particular, visou sanar a falta de literatura nacional, baseada em investigação científica e aplicação de técnicas no contexto real, visando a formação de quadros para a intervenção no campo da discriminação organizacional com base em orientação sexual e/ou identidade de gênero (LGBTfobia), em quaisquer ambientes de aprendizagem, não apenas escolas, por meio de dinâmicas, jogos, leituras e demais recursos audio-visuais, adequados às faixas etárias.

É fundamental apontar o trabalho de Reinaldo Bulgarelli (2008), não apenas como autor, mas principalmente como educador, conferencista e assessor em temas de sustentabilidade e responsabilidade corporativa (Txai Consultoria), como um motor fundamental para a movimentação do tema da gestão da diversidade nas organizações de trabalho privadas do Brasil, fundamentando ou inspirando o trabalho de diferentes figuras amplamente reconhecidas pelo empresariado nacional para a transformação dos viéses inconscientes, como Ricardo Sales (Mais Diversidade), Pri Bertucci (Diversity BBOX) e Guilherme Gobato (Diálogos Entre Nós), entre outros CEOs. 
Tudo isso forma um agrupamento de indicadores de como, e em que nível, está-se lidando com a diversidade nas organizações. Eles integram etapas do que se pode chamar de uma "Agenda de Diversidade", composta pela aplicação de técnicas, estratégias políticas e de manejo das interações sociais, com objetivo de estabelecer relações produtivas entre as várias dimensões de diversidade humana representadas em uma organização.

Uma Agenda de Diversidade é o resultado de esforços sistematizados a serviço dos fins organizacionais, com métodos bem delineados, que objetivam propiciar uma cultura que reconheça e valorize as semelhanças e diferenças entre as pessoas.

Vale ressaltar que Agendas de Diversidade e formulação de leis que combatam a discriminação são estratégias de âmbitos diferentes.

As leis se baseiam em juízos morais da sociedade e são reativas; agendas de Diversidade se baseiam em pesquisas e estudos que demonstram a vantagem competitiva de uma diversidade interna valorizada.

Agendas de Diversidade são proativas e orientadas para o desempenho, focalizando todos os integrantes da organização, desde o trabalhador do "chão de fábrica" até a alta diretoria.

As leis defendem a diversidade porque isso é socialmente considerado justo. As Agendas de Diversidade, por outro lado, o fazem porque membros discriminados em uma organização dispensam muita energia tendo de se defender psicológica e socialmente do preconceito e da discriminação, o que os torna menos produtivos, e as empresas, menos competitivas.

Agendas de Diversidade e Leis Anti-Discriminação não necessariamente afloram umas das outras, no entanto podem interagir positivamente.

De forma geral, é indispensável a formulação de uma Agenda de Diversidade, para além de ações afirmativas isoladas, porque é árdua a mudança dos comportamentos, valores e das crenças básicas de qualquer cultura ou subcultura, transformação que não se pode realizar com atividades assistemáticas e puramente centradas nos indivíduos, esquecendo-se dos grupos e das instituições.

Esse é o fundamento filosófico e metodológico de uma Agenda de Diversidade: o trabalho se dá em grupo e institucionalmente.

Comportamentos são expressões dos valores e crenças de uma cultura ou subcultura em face de determinadas circunstâncias. 
Comportamentos discriminatórios são mais acessíveis e fáceis de mudar do que as atitudes que os compõem. Atitudes preconceituosas (predisposições a discriminar) são compostas por valorações que, como oxímoros (ideias que envolvem conceitos opostos, como bom/ruim e certo/ errado), são mais fáceis de mudar do que as crenças básicas/estereótipos que os formam. Os estereótipos são a base das atitudes e dos comportamentos, fundamentando a lógica interna da estrutura social que orienta as ações de seus atores.

A transformação da lógica estereotipada que leva à discriminação deve começar pelos comportamentos, expressões visíveis, concretas, portanto, mais fáceis de mudar.

De acordo com Marx (1978), "a essência humana não é o abstrato residindo no indivíduo único. Em sua efetividade é o conjunto das relações sociais", essa assertiva sugere que as funções psicológicas - crenças, juízos estéticos e de valor, ideologias - são mais do que estruturas mentais, são construções individuais e sociais efetivadas pelo conjunto de relações constituídas em uma determinada estrutura social, e é avistando esse horizonte que podemos iniciar uma gestão da diversidade.

Estimulando-se dissonâncias cognitivas entre como os indivíduos se comportam e os seus valores, começa-se um processo de manipulação sistemática e demorada de seus preconceitos e, quiçá, dos estereótipos.

Cinco etapas compõem a Agenda de Diversidade: Análise da cultura organizacional; Identificação de possíveis grupos e líderes; Formulação de uma política de igualdade de oportunidades; Execução de práticas sistematicamente dirigidas para a valorização da diversidade; e Avaliação contínua do processo.

\section{Análise da cultura organizacional:}

A partir da qual poderão ser identificados estereótipos e preconceitos que definem os comportamentos e reações dos funcionários à implantação de uma gestão da diversidade. Variáveis outras podem estar afetando as relações interpessoais que não a cultura em si, como, por exemplo, problemas na remuneração e/ou no sistema de recompensas por desempenho, por isso, nessa etapa, um levantamento de necessidades é primordial.

As organizações precisam reconhecer, como objetivo aceitável, o de se tornarem comunidades inclusivas, "em que todos os membros consideram- 
se pertencentes e às quais acham que podem dar uma contribuição" (SAPONSHEVIN, 1999; p. 288).

\section{Identificação de possíveis grupos e líderes:}

Os quais facilitarão o trabalho do(a) gestor da diversidade, permitindo identificar os tipos de discriminação que precisam ser evidenciados, e grupos atingidos por eles, que precisam ser valorizados.

Indispensável aos grupos e aos seus líderes de grupos inclusivos é a capacidade de ter uma escuta ativa, que ouça o que o grupo tem a dizer, assim o grupo poderá conquistar seu poder de decisão.

Sem participação, não há como formar um grupo que seja uma comunidade inclusiva, que aprenda, pois, consequentemente, não se tomam decisões nem se age democraticamente, negando o fato de que apenas complementando as habilidades e poderes de cada pessoa é que um ajuntamento de seres humanos se torna um grupo coeso, apto a desenvolver seu próprio crescimento.

\section{Formulação de uma política de igualdade de oportunidades:}

Que pode ser delineada a partir da utilização de instrumentos metodológicos adequados ao contexto, tais como as dinâmicas dos Círculos de Amigos, dos MAPs - Making Action Plans (Formulando Planos de Ação) e do PATH - Planning Alternative Tomorrows with Hope (Planejando Futuros Alternativos com Esperança).

De acordo com Pearpoint, Forest e O’Brien (1999, p. 88),

tais instrumentos baseiam-se na esperança, no futuro e supõem que todas as pessoas estão inseridas, que todas as pessoas podem aprender, que todos se beneficiam de estar juntos e que a Diversidade é uma de nossas potencialidades fundamentais.

Os autores supracitados descrevem extensa e detalhadamente os passos a ser tomados durante a realização desses exercícios, que logo abaixo resumo.

O Círculo de Amigos (Figura 1) é relativamente simples, mas extremamente eficaz: ilustram-se quatro círculos concêntricos, e se os define, de dentro para fora, como (1) círculo da intimidade, (2) círculo da amizade, 
(3) círculo da participação e (4) círculo da troca. Quanto mais externo o círculo, menos íntima é a pessoa:

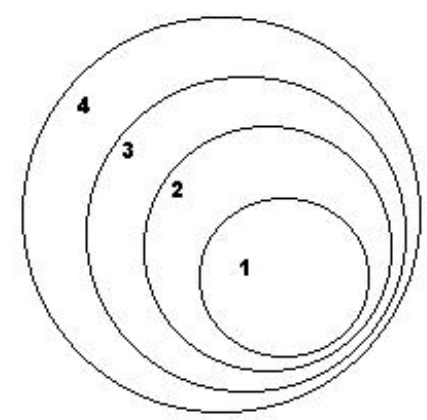

Figura 1: Círculo de Amigos, adaptado de Pearpoint, Forest e O’Brien (1999, p. 97).

Deve-se preencher os círculos de dentro para fora, de acordo com os nomes indicados pela pessoa representada pelos quatro círculos, guiandose por perguntas como: "Quem me ama?", "Quem é meu amigo?", “Quem eu gosto, mas não me é próximo?", e "Quem eu pago para estar em minha vida?", respectivas a cada círculo. Essa atividade leva as pessoas a uma avaliação pessoal, social e à compreensão da importância de uma rede de apoio.

Os MAPs são atividades, compostas por perguntas, que reúnem as pessoas principais para a vida da pessoa, e são aplicados por duas pessoas, uma que registra e outra que facilita o processo. Os MAPs são mapas, como sugere a tradução, no sentido em que indicam direções. Das perguntas se chega ao plano de ação.

O PATH é extensão dos MAPs, composto por oito passos, com a finalidade de propiciar a resolução de problemas por meio da formulação de um plano de ação possível. Propõem-se a ser "caminhos", tal como se lê na tradução do termo. Começa com um convite do facilitador à exploração de visões novas, resolução conjunta de problemas, propósitos e conflitos.

\section{Execução de práticas sistematicamente dirigidas para a valorização da diversidade:}

As quais demandam o conhecimento técnico de várias dinâmicas; algumas citadas anteriormente. A gestão da Diversidade é interdisciplinar, 
por isso deve ser concomitante, a partir da observação dos comportamentos que surgem durante o processo, a treinamentos em liderança, ética, ao investimento em recrutamento e seleção de pessoal o mais diverso possível, e a um processo educativo permanente, em que todos os membros da organização sejam e se reconheçam como aprendizes e educadores.

Fazendo-se aqui um paralelo com a área da Educação, concorda-se com esta afirmação de Munanga (2001, p.9):

Essa transformação fará de nós os verdadeiros educadores, capazes de contribuir no processo de construção da democracia brasileira, que não poderá ser plenamente cumprida enquanto perdurar a destruição das individualidades históricas e culturais das populações que formaram a matriz plural do povo e da sociedade brasileira.

\section{Avaliação contínua do processo:}

Pois àquele(a) que gere a diversidade não é cabível satisfazer-se unicamente com o resultado de uma avaliação final posteriormente arquivada.

Esse profissional deve avaliar o próprio desempenho e as estratégias utilizadas. Embora a avaliação "do processo durante o processo", ou formativa, aparentemente resulte em um gasto considerável de tempo com relação a outros programas, que só se avaliam ao término para melhorarem ações futuras (somativos), o fato é que o uso dessa estratégia possibilita reorganizar o planejamento inicial, de modo a não avançar enquanto algumas questões não estiverem bem resolvidas ou minimamente trabalhadas, o que assegura melhor a mudança, incorporando críticas, opiniões e sugestões dos participantes, as quais podem ir além do conteúdo programado, mas que envolvem a própria organização.

Há uma forte relação entre competências políticas e técnicas na formulação de uma Agenda de Diversidade, e o ato de valorizar as diferenças, por sua constituição mesma, não se destina a um julgamento definitivo que as empresas "têm de ter" sobre alguma pessoa, grupo ou situação.

Uma Agenda de Diversidade se destina à inclusão, e por isso mesmo à melhoria do ciclo de vida em seus múltiplos níveis: individual, grupal e organizacional. Todas e todos são responsáveis pela boa gestão da diversidade. 


\section{Considerações Finais}

A gestão da diversidade nas organizações, especialmente nas de trabalho, objetiva uma inclusão não apenas formal, discursiva, mas substancial, na qual, mais do que regras impostas pela alta gerência, predomina entre os funcionários uma cultura de equidade social, econômica e, se possível, jurídica.

Fundamental é que a organização esteja aberta à aprendizagem, a tentar algo novo e diferente; que fomente a segurança e o respeito à diversidade de opiniões; que não ignore ou minimize a importância do desconforto inevitável durante o processo; que se arrisque a errar, aprendendo com o que errou; que trabalhe os conflitos como pontos de discussão; que dê crédito aos sentimentos e observações das pessoas; e que seja objetiva no seu apoio à Agenda de Diversidade, ciente de que os funcionários só se comprometerão na sua coletividade se a alta diretoria estiver igualmente comprometida, outorgando liberdade de atuação e de acesso a informações para a equipe ou profissional que busca gerir a diversidade.

Sendo um sistema dentro de outro sistema (organização dentro da sociedade), a empresa ou instituição pública que valoriza a diversidade promove, mesmo que indiretamente, a valorização das diferentes dimensões da diversidade humana na sociedade, por meio do comportamento de seus funcionários nas comunidades das quais participam e da imagem social da organização.

Logo, um dos benefícios resultantes de uma gestão da diversidade é o de não isolar a organização a um papel restrito de reprodutora de injustiças sociais e limitações morais. A partir da implantação de uma política de valorização da diversidade, as empresas se tornam agentes coletivos de transformação social, apoio a novos talentos e agregação de valores que incitam outras organizações, ainda presas a um modelo arcaico de exclusão e de privilégios, a se mobilizarem para seguir esse exemplo.

Tal conquista o(a) gestor(a) da diversidade não alcança isolado(a), mas atuando interdisciplinarmente com outros profissionais e junto aos grupos que compõem a organização, fortalecendo suas estratégias e ações com eles. 
Enfim, considerando a complexidade da atual conjuntura política nacional, o empresariado, adotando políticas de gestão da diversidade, poderá contribuir para o avanço da democracia brasileira, estimulando o desenvolvimento de políticas de reparação aos diversos grupos sociais historicamente discriminados. 


\section{REFERÊNCIAS}

ADLER, N. J. \& BOYACIGILLER, N. Global organizational behavior: going beyond tradition. Journal of International Management, v. 1, p. 73-86, 1995.

ALLPORT, G. W. The nature of prejudice. Reading: Addison Wesley, 1954.

ANDRÉ, M. C. Processos de subjetivação em afro-brasileiros: anotações para um estudo. Psicologia: Teoria e Pesquisa, 23(2), p. 159-167, 2007.

BRASIL. Constituição da República federativa do Brasil. Brasília: Senado Federal, Centro Gráfico, 1988.

BULGARELLI, R. Diversos somos todos: valorização, promoção e gestão da diversidade nas organizações. São Paulo: Editora de Cultura, 2008.

BUNTAINE, C. S. \& JOHNSON, M. N. 10 questões normalmente feitas (ou não) sobre diversidade cultural e organizações. The Kaleel Jamison Consulting Group. Trad.: Torres, C. V. Estados Unidos. Mimeografado, 1996.

CARDOSO, F. H. Construindo a democracia racial. Brasília: Imprensa Nacional, 2000.

CARONE, I., \& BENTO, M. A. S. Psicologia social do racismo: estudos sobre branquitude e branqueamento no Brasil. Petrópolis: Vozes, 2002.

COX, T. Jr. \& BLAKE, S. Managing cultural diversity: implications for organizational competitiveness. Academy of Management Executive, v. 5, n. 3, p. 45-56, 1991.

COX, T. Jr. Cultural diversity in organizations: theory, research and practice. San Francisco: Berrett-Koehler Publishers, 1994.

FLEURY, M. T. L. Gerenciando a diversidade cultural: experiências de empresas brasileiras. Revista de Administração de Empresas, 40(3), p. 18-25, 2000.

GOMES, J. B. B. Ação afirmativa e princípio constitucional da igualdade. Rio de Janeiro: Renovar, 2001.

GOMES, N. L. A mulher negra que vi de perto: o processo de construção da identidade racial de professoras negras. Belo Horizonte: Mazza, 1995.

JACOBO, J. (1997). Juventude, violência e cidadania: os jovens de Brasília. Brasília: UNESCO, 1997.

JESUS, J. G. O desafio da convivência: assessoria de diversidade e apoio aos cotistas (20042008). Psicologia: Ciência e Profissão, v. 33, n.1, p. 222-233, 2013. Disponível em: http://www. scielo.br/pdf/pcp/v33n1/v33n1a17.pdf

JESUS, J. G. Homofobia: identificar e prevenir. Rio de Janeiro: Metanoia Editora, 2015.

LIMA, M. E. O., \&VALA, J. Sucesso social, branqueamento e racismo. Psicologia: Teoria e Pesquisa, 20(1), p. 11-19, 2004.

LIZUKA, E. S. \& BRINCAS, M. R. Voluntariado no Brasil: plantando sementes. Trabalho apresentado no IX Encontro do I Programa Trainee GIFE. Estados Unidos, 1999. 
MARX, K. Manuscritos econômico-filosóficos e outros textos escolhidos. São Paulo: Abril Cultural, 1978.

MINISTÉRIO DA JUSTIÇA. Programa nacional de direitos humanos. Brasília: Imprensa Nacional, 1998.

MINISTÉRIO DO TRABALHO E DO EMPREGO. Programas de promoção da igualdade: guia de elaboração. Brasília: Imprensa Nacional, 2000.

MOREIRA, D. Reflexões sobre mudanças sócio-raciais no Brasil. In: Racismos contemporâneos. Rio de Janeiro: Takano Editora Gráfica, 2003.

MUNANGA, K. Apresentação. In: K. Munanga (Org.). Superando o racismo na escola. Brasília: Ministério da Educação, 2001.

NKOMO, S. M., \& COX, T. Jr. Diversidade e identidade nas organizações. In: S. R. Clegg, C. Hardy \& W. R. Nord (Orgs.). Handbook de estudos organizacionais: modelos de análise e novas questões em estudos organizacionais. São Paulo: Atlas, p. 334-360, 1999.

ORGANIZAÇÃO INTERNACIONAL DO TRABALHO. Igualdad en el empleo y la ocupación. Genebra: OIT, 1996.

PEARPOINT, J., FOREST, M. \& O’BRIEN, J. MAPs, Círulos de Amigos e PATH: instrumentos poderosos para ajudar a construir comunidades protetoras. In S. Stainback \& W. Stainback (Orgs.). Inclusão: um guia para educadores. Porto Alegre: Artes Médicas, 1999, p. 69-87.

PÉREZ-NEBRA, A. R. \& JESUS, J. G. Preconceito, estereótipo e discriminação. In: C. V. Torres \& E. R. Neiva (Orgs.). Psicologia social: principais temas evertentes. Porto Alegre:ArtMed, 2011, p. 217-237.

SANTOS, A. S. Discriminação: uma questão de direitos humanos. In: $\mathbf{5 0}$ anos depois: a declaração universal dos direitos humanos. Brasília: MNDH, 1999.

SAPON-SHEVIN, M. Celebrando a diversidade, criando a comunidade: o currículo que honra as diferenças, baseando-se nelas. In: S. Stainback \& W. Stainback (Orgs.), Inclusão: um guia para educadores. Porto Alegre: Artes Médicas, 1999, p. 288-305.

SECRETARIA DE DIREITOS HUMANOS. Programa Brasil Sem Homofobia. Brasília: Imprensa Nacional, 2004.

SILVÉRIO, V. R. Ação afirmativa e o combate do racismo institucional no Brasil. Cadernos de Pesquisa, 117, p. 219-246, 2002.

TAJFEL, H. Social psychology of intergroup relations. Annual Review of Psychology, v. 33, p. 1-39, 1982.

TAPIOLA, K. Empresas multinacionais e os desafios sociais do século XXI. Brasília: Estação Gráfica, 2000.

TORRES, C. V. \& DESSEN, M. A. Valores culturais e a cultura brasileira: desdobramentos teóricos. In M. L. M. Teixeira (Org.). Valores humanos e gestão: novas perspectivas. São Paulo: Editora Senac, 2008, p. 95-116.

TORRES, C. V. \& PÉREZ-NEBRA, A. R. Diversidade cultural no contexto organizacional. In J. C. Zanelli, J. E. Borges-Andrade \& A. V. B. Bastos (Orgs.). Psicologia, organizações e trabalho no Brasil. Porto Alegre: ArtMed, 2004, p. 441-463. 


\title{
UM BALANÇO CRÍTICO ACERCA DA REGRESSÃO DOS DIREITOS LGBTI NO BRASIL SOB ASCENSÃO DO BOLSONARISMO
}

\author{
Bruna Andrade Irineu \\ Brendhon Andrade Oliveira \\ Milena Carlos Lacerda
}

A interpretação teórica e política da ascensão da extrema direita no Brasil fundamenta-se nas determinações sócio-históricas da formação social enraizadas na dinâmica do capitalismo dependente, do sistema heteropatriarcal e das desigualdades étnicorraciais. $O$ resgate do debate crítico que historiciza a teorização da liberalização da economia na reprodução ampliada do capital e a gestação da escalada conservadora global lançam luz as contradições contemporâneas agudizadas com o prolongamento da crise econômica, política, social e ambiental.

Posto este pressuposto analítico, objetivamos problematizar o avanço da extrema direita no Brasil, a partir da chamada "Nova Direita". Tais reflexões aproximativas buscam contextualizar a ofensiva neoconservadora na quadra contemporânea e seus impactos imediatos na vida da população LGBTI (Lésbicas, Gays, Bissexuais, Travestis, Transexuais e Intersexuais), à luz da teoria social crítica e dos estudos de gênero e sexualidades.

Sabe-se que a articulação da frente neoconservadora com o neoliberalismo se expressa com a eleição de Ronald Reagan nos Estados Unidos nos anos de 1980. Na particularidade brasileira, a expressão vitoriosa dessa congregação se apresente com maior nitidez na eleição de Jair Bolsonaro, em 2018. No entanto, não podemos perder de vista que a aglutinação das mobilizações da extrema direita projeta suas ações, ainda que timidamente, em meados dos anos 2000, notadamente com repercussões da ascensão da direita por dentro do governo de contribuição de classes. 
Neste ensaio, apontamos que a dimensão política das formas de governo está atrelada as regulações gerais do capital, ao passo, que a envergadura do capitalismo no Brasil, especialmente no Governo Bolsonaro, aponta para importância de conceber a imbricação do jogo político e econômico nas relações sociais. Além disso, temos que elucidar o desenvolvimento do capitalismo contemporâneo no continente latino-americano, em especial do Brasil, pois os rebatimentos da ofensiva do capital e do acirramento do neoliberalismo são sentidos de forma diferenciada nas economias dependentes e periféricas.

Essa apreensão materialista da indissociabilidade entre a esfera política e econômica (WOOD, 2003) nos oportuniza compreender a atuação e conformação do Estado e dos regimes políticos que, na fase atual do capitalismo, propagam o peso excessivo do Estado e o custo elevado das políticas sociais para a economia, propondo a redução, enxugamento e transferência dos serviços e equipamentos públicos para o mercado (BOSCHETTI, 2018).

Objetiva-se, portanto, expor como a tônica de ofensiva aos direitos sexuais e reprodutivos tem se tornado central na agenda da extrema direita, refletindo os retrocessos dos dois anos do atual governo. Atentandose especialmente aos direitos e políticas públicas para população LGBTI (lésbicas, gays, bissexuais, travestis, transexuais e intersexuais), cujo cenário de ataque tem agudizado a política de extermínio gestada pelo Estado capitalista ${ }^{24}$.

\section{O avanço da Nova Direita no país sem legislação pró-direitos LGBTI}

Desde o período Constituinte (1986/87), há disputas por direitos e políticas públicas LGBTI. Em 1995, foram submetidos dois projetos de leis específicos ao Congresso Nacional, um sobre "união civil" e outro sobre mudança de prenome para transexuais que se submeteram à cirurgia de

\footnotetext{
${ }^{24}$ Este texto é um desdobramento do artigo "Direitos LGBTI sob ataques no Brasil: Notas sobre o efeito da ascensão da Nova Direita e do bolsonarismo" (prelo) de autoria de Milena Lacerda, Bruna Irineu e Brendhon Andrade que que irá compor o ebook "Políticas Públicas, Desigualdades Sociais e Marcadores Sociais da Diferença" organizado pelo Grupo de Pesquisa em Gênero, Ética, Educação e Política (GEEP) da UNIPAMPA.
} 
redesignação sexual. Todavia, assim como todas outras demandas advindas do movimento LGBTI na arena da política institucional, restaram infrutíferas.

Até os dias atuais, os direitos sexuais e reprodutivos têm enfrentado conservadorismos institucionalizados no Poder Público. Políticos conservadores estão organizados por meio da Frente Parlamentar Evangélica no Congresso Nacional, e tem promovido, do púlpito à tribuna, pânicos morais que promovem discursos 'em defesa da família tradicional' e contra a 'ideologia de gênero', alocando movimentos LGBTI e feministas como agentes do mal e da imoralidade. O impacto imediato é a não aprovação de nenhuma legislação específica, culminado na judicialização dos direitos LGBTI como estratégia de reconhecimento jurídico por meio da Jurisdição Constitucional (IRINEU e OLIVEIRA, 2020; IRINEU et al, 2019).

Em relação às políticas públicas, o II Plano Nacional de Direitos Humanos (2002), no governo FHC, trouxe a primeira referência à comunidade LGBTI, ao qual previa o direito à livre orientação sexual e proibição de discriminação. $A$ partir, então, do Governo Lula, as demandas do ativismo LGBT ganham maior espaço no Poder Executivo, cuja maior expressão é a criação da primeira política pública específica LGBT, o Brasil Sem Homofobia (BSH), em 2004, que tinha por objetivo a promoção da cidadania homossexual e combate da violência e discriminação.

Diversas ações e políticas para a população LGBT estão presentes nos Governos Petistas (2003-2016). Há que citar as Conferências Nacionais LGBT de 2009, 2011 e 2016, que, por meio da participação social de ativistas e Poder Público, objetivavam construir políticas públicas. Há o Brasil Sem Homofobia (2004); o I Plano Nacional de Promoção e Cidadania e Direitos Humanos de LGBT (2009); o Conselho Nacional de Combate à Discriminação de LGBT (2010); o Disque 100 - Direitos Humanos (2011); a Política Nacional de Saúde Integral da População LGBT (2011); e o criação do Sistema Nacional de Enfrentamento à Violência LGBT (2013); entre outros.

Embora esses governos tenham criado políticas e ações voltadas à promoção dos direitos LGBTI, há descontinuidades entre as gestões de Lula e Dilma, bem como ambiguidades e contradições que comprometem o desenvolvimento dessas políticas (IRINEU, 2019). Nesse caminho, pode-se compreender o histórico de política pública LGBT no Brasil através de "restrições orçamentárias, ações descontínuas e uma vontade política subsumida a negociações com segmentos conservadores" (IRINEU, 2019, p. 301). 
Tanto que, a despeito dos Planos de Políticas Públicas preverem aprovação de legislações protetivas, os governos petistas não cumpriram tais 'promessas' de reconhecer, por meio de legislação, os direitos LGBTI, que, em diversas ocasiões, foram utilizados como moeda de troca com os setores conservadores e reacionários. ${ }^{25}$

No ano de 2016, em que se realiza a $3^{\text {a }}$ Conferência Nacional LGBT, a Presidenta Dilma Rousseff promulgou o Decreto $\mathrm{n}^{\circ} 8.727$, de 28 de abril de 2016, reconhecendo a utilização do nome social para pessoas Trans no âmbito da administração pública direta, autárquica e fundacional. Pouco tempo depois se consuma o Golpe Jurídico-Parlamentar que impedia a Presidenta em exercício. Os resultados obtidos na Conferência não tomaram forma de um Plano de Políticas Públicas no governo sucessor, que, por sua vez, engrossou o caldo político e econômico da expansão da extrema-direita no Brasil e da agenda neoliberal.

Assumindo a Presidência da República ainda em 2016, após o projeto de ruptura institucional, Michel Temer publica sua primeira medida provisória (726/2016), que trazia uma reforma presidencial que reduzia de 32 para 23 o número de Ministérios sob o argumento de "corte de gastos", entre eles o Ministério das Mulheres, da Igualdade Racial, da Juventude e dos Direitos Humanos, responsável pelas políticas voltadas ao público LGBT.

$\mathrm{O}$ antigo ministério se tornava uma Secretaria Especial de Direitos Humanos, nas dependências do Ministério da Justiça. Um mês após a reforma ocorrida em maio, o governo publicou um Decreto transferindo as dotações orçamentárias do extinto ministério para a Presidência da República. Em 2017, o governo recua dadas as projeções negativas e pressões de movimentos por Direitos Humanos, criando o Ministério de Direitos Humanos (Medida Provisória $n^{\circ} 768$ ), todavia, sem quaisquer menções orçamentarias, sequer no sentido de reabilitar o antigo orçamento.

Embora o crescimento da extrema direita na particularidade brasileira não se explicar somente à luz do golpe jurídico-parlamentar que depôs a

\footnotetext{
${ }^{25}$ Essa realidade descrita, em alguma medida e considerando as devidas proporções, se repete em âmbitos estaduais e municipais, naquelas localidades em que, em algum momento, instituiu algum tipo de ação ou política pública direcionadas à comunidade LGBTI. A exemplo disso, recomendase o texto 'Um estudo entre ruínas: o programa Rio Sem Homofobia e a política LGBTI Fluminense' de Luan Cassal (2018).
} 
presidenta Dilma, Temer representava a aliança entre conservadorismo e neoliberalismo, que mais tarde tomaria dimensões maiores com Bolsonaro.

O papel do Poder Judiciário nesse contexto é contraditório. Havia uma força institucionalizada anti-esquerda com a Operação LavaJato que deram subsídios ao golpe de 2016, organizado pelos setores reacionários, conservadores, empresariais e elitistas, "com o Supremo, com tudo", conforme proferido por Romero Jucá, que era deputado do MDB e protagonista no golpe. Esse cenário reafirma o direito e instituições judiciárias como a forma jurídica do Estado capitalista.

Socialmente, este governo fortalece um populismo que pode ser caracterizado por seu caráter a) anti-gênero (manutenção da ordem de gênero que submete o feminino ao domínio da masculinidade hegemônica); b) anti-diversidade (em relação às cidadanias LGBTI e da população negra); c) militarização e punitivismo (advindas da lava jato, criminalização do jovem negro, crise de segurança pública e negação dos direitos humanos); d) prómeritocracia e anti-direitos sociais (a qual se expressa por meio de posturas contrárias às políticas sociais, como cotas e distribuição de renda) e, e) em favor do mercado (promovendo contrarreformas e políticas favorecendo a classe de empresários) e f) radicalização autocrática (com o número expressivo de militares nas distintas pastas do governo).

O projeto de desmonte de Temer, apesar do pouco tempo que the restava, caminhou a todo vapor. Avançou-se no ataque às políticas públicas de direitos humanos, enfraquecendo a pasta em âmbito federal, e também sobre as políticas sociais, com a aprovação da Emenda à Constituição $n^{\circ}$ 55, que instituiu Novo Regime Fiscal que vigorará por 20 anos, impondo limites para as despesas primárias dos três Poderes. Não obstante, o Governo Temer promovia a Reforma Trabalhista, de 2017, e ainda tentou articular aprovação da Reforma da Previdência, que, entretanto, fora aprovada no Governo Bolsonaro.

A Contrarreforma Trabalhista, em evidente estratégia homonacionalista, trouxe a sexualidade em sua previsão de dano extrapatrimonial como um dos bens juridicamente tutelados inerentes à pessoa humana. Em uma primeira leitura, poderia se retirar que a nova legislação avançaria na proteção jurídica daquelas/es orientações sexuais não-heterossexuais. No entanto, o objetivo central da legislação é a precarização do trabalho em favor do mercado, impactando também na empregabilidade, renda e relações de trabalho das 
pessoas LGBTI. É por esse motivo que não há como enxergar tal dispositivo como um avanço no ordenamento jurídico pátrio.

Por outro lado, a Jurisdição Constitucional, materializada no controle de constitucionalidade ${ }^{26}$, e o papel contramajoritário do Supremo Tribunal Federal ${ }^{27}$ possibilitaram o reconhecimento de direitos LGBT $^{28}$ que estão listados na tabela abaixo.

Tabela 1 - Levantamento de Direitos LGBTI na Democracia Constitucional

\begin{tabular}{|c|c|l|}
\hline Órgão & Ano & Instrumento jurídico \\
\hline STF & 2011 & $\begin{array}{l}\text { Ação Direta de Inconstitucionalidade 4.277/DF (sobre a união } \\
\text { estável entre pessoas do mesmo sexo) }\end{array}$ \\
\hline STF & 2015 & $\begin{array}{l}\text { Arguição de Descumprimento de Preceito Fundamental } n^{\circ} 291 \\
\text { (Descriminalização da pederastia no Código Penal Militar) }\end{array}$ \\
\hline STF & 2018 & $\begin{array}{l}\text { Ação Direta de Inconstitucionalidade 4.275/DF (sobre } \\
\text { identidade de gênero) }\end{array}$ \\
\hline STF & 2019 & $\begin{array}{l}\text { Ação Direta de Inconstitucionalidade Por Omissão } n^{\circ} \text { 26/DF } \\
\text { (sobre a criminalização da homofobia) }\end{array}$ \\
\hline STF & 2020 & $\begin{array}{l}\text { Ação Direta de Inconstitucionalidade } n^{\circ} 5543 \text { (dispositivos } \\
\text { resolutivos que proíbem doação de sangue por homens gays) }\end{array}$ \\
\hline STF & Em & $\begin{array}{l}\text { Arguição de Descumprimento de Preceito Fundamental } n^{\circ} 600 \\
\text { (discussão acerca de dispositivo em lei municipal que proíbe } \\
\text { discussão de gênero nas escolas) }\end{array}$ \\
\hline
\end{tabular}

Fonte: Pesquisa direta.

Frente a esse cenário sócio-histórico que evidencia a ascensão da Nova Direita em detrimento da esquerda petista, tem-se que "o recrudescimento

${ }^{26}$ Trata-se da possibilidade de invalidação de atos do Poder Público não compatíveis com a Constituição Federal. Essa ferramenta jurídica foi criada pelo direito pós-guerras, ao qual, surge pela necessidade de preservação e proteção dos direitos humanos e fundamentais, bem como a garantia e estabilidade do Estado de Direito.

${ }^{27}$ Ressalte-se que as ações levantadas se referem àquelas que foram submetidas diretamente no Supremo Tribunal Federal por meio de processo constitucional que se traduz em controle de constitucionalidade concentrado.

${ }^{28} \mathrm{O}$ direito à adoção (2010), a inscrição de parceiro homossexual como dependente preferencial no Regime Geral de Previdência (2010) e o direito ao casamento (2011) foram reconhecidos pela via difusa, tendo o Superior Tribunal de Justiça consolidado a jurisprudência em sentido positivo. O controle de constitucionalidade difuso pode ser compreendido como aplicação incidental no cotidiano dos órgãos que formam as Instituições Judiciárias. 
do conservadorismo, frente às demandas dos movimentos que lutam pela inserção de pauta dos direitos sexuais e reprodutivos, caminha paralelo às conquistas destes grupos no campo da cidadania" (IRINEU, 2020, p. 18). 0 Governo Temer representa as mudanças que avançaram na corrosão dos direitos sociais e dos direitos humanos, culminando na devastação social "de uma classe trabalhadora cada vez marcada pela heterogeneidade, precariedade e fragmentação, assim como pelos seus recortes de raça, gênero e geração" (ANTUNES; PRAUN, 2019, p. 78).

\section{O ataque aos direitos LGBTI como expressão política da Nova Direita brasileira}

As terminologias neoliberalismo e neoconservadorismo têm sido recentemente conjugadas, apesar de possuírem trajetórias e significados diferentes. Com a crise do Welfare State em meados da década de 1970, essas denominações ganham força no cenário de reordenação do capitalismo, que se deu através do receituário neoliberal (BOSCHETTI, 2018), promovendo a concentração de capital e distribuindo o ônus da crise por meio da precarização do trabalho, do desemprego estrutural e, por consequência, da reestruturação produtiva.

O processo de desilusão estadunidense com o liberalismo e conservadorismo moderado, que intensifica a oposição ao comunismo e fortalece o surgimento de uma nova geração de conservadores norteamericanos, unindo as ideias clássicas do liberalismo e o repositório moral conservador, explicam a origem ao neoliberalismo e neoconservadorismo. Assim, os neoconservadores partilharam de princípios iguais aos neoliberais, como a crença de que o Estado não deve interferir na economia e a ideia de que programas sociais geram endividamento, inflação e do ponto de vista moral ainda desestimularia o trabalho e desenvolvimento da sociedade ${ }^{29}$ (PEREIRA, 2020).

A terminologia "nova direita" remonta as eleições estadunidenses de 1980, na qual Ronald Reagan saiu vitorioso com forte apoio de uma coalização

\footnotetext{
${ }^{29}$ As lentes neoconservadoras compreendem que os papéis da família, Igreja e comunidade foram atribuídos ao Estado por meio de políticas sociais. Em outras palavras, o neoconservadorismo apresenta-se como uma forma atualizada do conservadorismo clássico articulando seus valores morais reacionários ao receituário econômico do neoliberalismo.
} 
conversadora, que reunia lideranças expressivas neoconservadoras. Reagan presidiu os Estados Unidos durante o início da epidemia da aids, atuando como um governo mergulhado em pânicos morais, cuja negligência intensificou a letalidade da doença.

No Brasil, os militares ainda controlavam o Poder Público à época da transição em que ocorre a Constituinte de 1986/87 e, embora o discurso de defesa da família fora acionado para impedir a contemplação da sexualidade enquanto um marcador protegido pelo artigo da não-discriminação, não havia neoconservadores e neoliberais assim nomeados e substancialmente em aliança. Entretanto, o debate público foi marcado por traços do conservadorismo, no qual os setores religiosos e ruralistas já se faziam presentes, ainda que organizados diferentemente das formas atuais, concretizadas nas bancadas evangélica e ruralista ${ }^{30}$.

De acordo com Junqueira (2018), a convergência entre o neofundamentalismo religioso e neoliberalismo é projetada por frações conservadoras que passam a aderir elementos da agenda antifeminista e anti-LGBTI, vinculando-a às estratégias do livre mercado, "costumam apontar como interferência indevida do Estado no espaço sagrado das famílias", como também expressar a convergência com os ataques ao Estado social (JUNQUEIRA, 2018, p. 457).

No entanto, quando se trata de políticas de ajuste fiscal, todos esses fazem ampla defesa, não à toa o atual Ministro da Economia Paulo Guedes, representante do Chicago Boys, foi o nome que assegurou apoio desses partidos e outros mais a Bolsonaro nas eleições de 2018. Também pode-se perceber uma frente ampla quando se trata de aprovar direitos sexuais e reprodutivos nos Poderes Políticos, uma vez que esbarram na moral religiosa hegemônica, tanto que essas questões têm sido levadas à Jurisdição Constitucional, como são os casos do aborto anencefálico e direitos LGBTI (OLIVEIRA, 2020).

Apesar desses grupos nem sempre estarem em pleno acordo, se aliaram em torno de pautas antigoverno no período de presidência de Dilma Rousseff

\footnotetext{
${ }^{30} \mathrm{Na}$ política brasileira, são raros aqueles que se apresentam como neoconservadores ou neoliberais, mesmo que apresentam programática explicitamente neoconservadora e neoliberal. É comum ver quadros do PSDB e DEM, como João Dória e Rodrigo Maia, respectivamente, que se alinham com o modelo neoliberal. E há figuras como Jair Bolsonaro, Eduardo Cunha (MDB) e Marco Feliciano (PSC) que se comprometem com as ideias neoconservadoras de 'mais família e menos Estado'.
} 
(PT), por exemplo. É nesse sentido, portanto, que se compreende aqui que essas duas concepções estão combinadas, formando o 'núcleo' do que vendo sendo nomeada de Nova Direita no Brasil, potencializadas no cenário das Jornadas de Junho (CEPÊDA, 2019; MELO, 2019).

Diante dessa amálgama, a ideologia de mercado se fortalece como modelo de negócios e teológico de Estado, ao passo que aprofunda o desmonte dos direitos da classe trabalhadora. Ainda que domínios distintos, o neoconservadorismo e neoliberalismo se opõem a valores como as liberdades civis, eleições democráticas, equidade e o próprio Estado de Direito (BROWN, 2006).

Embora os fundamentos principiológico do neoconservadorismo e do neoliberalismo separados não coadunem, o moralismo, o estatismo e o autoritarismo do neoconservadorismo habitam a razão neoliberal (BROWN, 2006). Assim sendo, a solidariedade e afeições comunitárias são sobrepostas pela moralidade neoconservadora do sujeito neoliberal hiperindividualizado.

Os projetos neoconservadores antidemocráticos carregam a racionalidade neoliberal. A título de exemplo, nos contextos de formulação e execução de políticas públicas de educação brasileiras, a presença de movimentos anti-igualitários foi essencial na retirada de gênero de planos governamentais estaduais e municipais (MISCKOLCI; PEREIRA, 2019).

A utilização de Fake News combinadas com pânicos morais, como o 'Kit Gay' e 'ideologia de gênero', foram centrais no discurso de candidatura de Jair Bolsonaro em 2018, e ainda continuam fortes aliadas na governabilidade e manutenção da aprovação pública do governo. Aliás, quando explodem notícias que afetam negativamente o Governo Federal, tornou-se corriqueiro Jair Bolsonaro e Damares Alves (Ministra da Mulher, Família e Direitos Humanos) acionarem o neoconservadorismo e Fake News para balancear a avaliação em seus currais eleitorais.

Thalita Melo (2019), ao cartografar a estética da Nova Direita no Brasil, entende que essas forças anti-igualitárias, que contam com extenso aparato nas redes sociais no tempo recente, evidenciam que a neutralidade típica da velha direita não se revela no atual cenário. Em sua eleição, Bolsonaro se ausentou de debates com outros/as candidatos/as ilustrando suas intenções dedemocratizadoras e investiu sua comunicação eleitoral quase que exclusivamente em redes sociais, as quais se tornavam vetores de Fake News produzidas com fins a beneficiá-lo, como a 'mamadeira de piroca', 
e ainda performava proximidade com seu público que se embebia nessa narrativa bolsonarista da pós-verdade.

Desde que assumiu o Palácio do Planalto, Jair Bolsonaro tem cumprido seus compromissos com a agenda neoliberal de austeridade e ajustes fiscais, assim como tem investido na disseminação da moralidade neoconservadora em defesa da família tradicional, dando continuidade à cruzada antigênero (CORREA, 2018) que já havia se institucionalizado no Poder Legislativo (OLIVERA, 2020).

A cruzada antigênero se utiliza de diversos mecanismos. Além da Frente Parlamentar Evangélica constituída no Congresso Nacional, podese citar o enfraquecimento dos setores em órgãos do governo responsáveis pela criação e promoção dos direitos sexuais e reprodutivos, bem como a nomeação de pessoas engajadas no movimento Pró-Vida (anti-aborto), sobretudo aquelas ligadas à Igreja Universal do Reino de Deus (IURD), Associação Nacional de Juristas Evangélicos (ANAJURE) e setores da Renovação Carismática da Igreja Católica.

A constituição do projeto neoliberal e neoconservador tende a afetar sobremaneira a população LGBTI, não somente por que o governo atual é radicalmente avesso às diversidades e as diferenças, mas também, por que essa programática retira recursos das políticas sociais como um todo, alargando o desmonte dos direitos trabalhistas e sociais e o barateamento da força de trabalho, o que impacta de diferentes formas, os sujeitos concretos que compõe o Movimento LGBTI (TOITIO, 2019).

Apresenta-se, a seguir, uma sistematização que colaboram na compreensão dos retrocessos vinculados diretamente a comunidade LGBTI nos dois primeiros anos do governo Bolsonaro. 
Tabela 2 - Retrocessos para população LGBTI no Governo Bolsonaro (2019-2020)

Janeiro/2019: Extinção da Secretaria de Educação Continuada, Alfabetização, Diversidade e Inclusão), órgão do MEC responsável Ministério da pela promoção de ações transversais sobre gênero, orientação sexual, Educação - MEC identidade de gênero, deficiências e condição geracional.

Janeiro/2019: Retirada da diretriz de promoção e defesa dos direitos da população LGBTI na reestruturação do Ministério das Mulheres, Família e Direitos Humanos - MMFDH

Ministério das Mulheres, Família e Direitos Humanos MMFDH

Janeiro/2019: Ministra Damares Alves discursa em sua posse que "Meninos vestem azul e meninas vestem rosa" e que em sua gestão "meninos voltarão a ser príncipes e meninas princesas"

Ministério das Mulheres, Família e Direitos Humanos MMFDH

Fevereiro/2019: Reorientação das campanhas específicas de prevenção às IST/Aids desconsiderando as especificidades da população de homens gays e bissexuais, travestis, mulheres LBT e homens trans. A justificativa do novo Ministro é "não ofender as famílias"

Maio/2019: Extinção do Departamento de HIV/Aids que passou a ser Departamento de Doenças de Condições Crônicas e Infecções Sexualmente Transmissíveis

Ministério da Saúde $-M S$

Junho/2019: Extinção do Conselho Nacional de Combate à
Discriminação LGBT (CNCD)

Ministério das

Ministério da Saúde - MS

Mulheres, Família e

Direitos Humanos MMFDH

Agosto/2019: ANCINE proíbe o financiamento de filmes com temática LGBTI

Agência Nacional de Cinema (ANCINE)

Setembro/2019: Cancelamento do Vestibular com cotas destinadas a pessoas trans na Unilab

Ministério da Educação - MEC

Dezembro/2019: Não convocação e não realização da Conferência Nacional de Direitos Humanos LGBT prevista para o final de 2019 pelo CNCD LGBT Ministério das Mulheres, Família e Direitos Humanos MMFDH

Setembro/2019: Ministro Milton Ribeiro se pronuncia sobre suas intenções de mudança acerca da educação sexual nas escolas e atribui "homossexualismo à família desajustadas"

Fevereiro/2020: MMFDH lança campanha \#tudotemseutempo que estimula a abstinência sexual como método contraceptivo

Ministério da Educação - MEC

Ministério das Mulheres, Família e Direitos Humanos MMFDH

Outubro/2020: Advocacia Geral da União (AGU), entra com pedido de revogação da decisão do STF que equiparou a discriminação à LGBTI ao racismo 
Considerando a sistematização acima, compreende-se que os direitos sexuais e reprodutivos vêm se tornando o foco mais evidente dos movimentos anti-igualitários, principalmente em relação às políticas sociais de educação e saúde, embora essa ofensiva também mantenha e aprofunde desigualdades étnico-raciais e de classe social.

Miskolci e Pereira (2019) destacam que os ataques à educação superior pública, que se materializam sob ameaças às ações afirmativas, especialmente as cotas, tem se fundamentado em acusações de ineficiência da Administração Pública e má gestão, se alinhando à razão neoliberal conforme apontado anteriormente.

Além disso, o Governo Bolsonaro não apresentou planos e estratégias de enfrentamento à pandemia do COVID-19, e, ainda, em diversas ocasiões relativizou seus efeitos e impactos, tratando-a como uma 'gripezinha'. Utilizou-se da máxima 'a economia não pode parar', ainda que mais de 160 mil mortes fossem o resultado ao final do ano de 2020 no Brasil.

O compromisso neoliberal do governo se revela também na Contrarreforma da Previdência (Emenda Constitucional $n^{\circ} 103$, de 12 de novembro de 2019) e também pelas inúmeras medidas provisórias implementadas na pandemia que dariam continuidade a precarização do trabalho. Nesse sentido,

[...] a organização e as condições de trabalho tendem a piorar, sobretudo pelo home office (conforme tende a se configurar) e a uberização; a precarização da saúde dos trabalhadores é sentida na medida em que as ocupações precárias não pressupõem medidas de proteção à saúde juridicamente consistentes, e com a pandemia, a questão da exposição ao novo coronavírus catalisou o processo, tanto pela infecção em si quanto pelas suas repercussões psicológicas e sociais; (SOUZA, 2020, p. 12).

Nesse cenário posto, estudos apontam que "os efeitos desta crise sobre o mercado de trabalho foram imediatos e afetaram de forma diferenciada os trabalhadores. Os mais afetados em termos de perda de ocupação foram as mulheres, os mais jovens, os pretos e os com menor nível de escolaridade" (BARBOSA; COSTA; HECKSHER, 2020, p. 61). 
Especificamente sobre a comunidade LGBTI, um estudo publicado pelo site Gênero e número ${ }^{31}$ indicam que a taxa de desemprego foi de 21,6 - quase o dobro do registrado pelo IBGE, no trimestre encerrado em abril, referente a toda população brasileira (12,6\%). Além disso, $24 \%$ das pessoas LGBTI perderam emprego durante o isolamento social.

A postura do governo Bolsonaro frente à pandemia expressa suas bases neoconservadoras e neoliberais, uma vez que a vida da classe trabalhadora, que é fortemente marcada por raça, gênero e sexualidade, importa menos, configurando-se como meras engrenagens descartáveis do Estado Capitalista. Nesse sentido,

A condição precária designa a condição politicamente induzida na qual certas populações sofrem com redes sociais e econômicas de apoio deficientes e ficam expostas de formas diferenciadas às violações, à violência e à morte. Essas populações estão mais expostas a doenças, pobreza, fome, deslocamentos e violência sem nenhuma proteção (BUTLER, 2018, p. 46-47).

Butler (2018) argumenta que há vidas que não são passíveis de luto, embora a precariedade da vida seja uma condição compartilhada entre todos/as humanos/as. Nesse cenário, aquelas pessoas em contexto de capitalismo dependente e superexploração, alocadas geopoliticamente no Sul Global que ainda enfrenta as marcas deixadas pelo colonialismo, submetidas cotidianamente às violências estruturais, têm suas precariedades politicamente induzidas potencializadas.

Isso implica, inclusive, na percepção de horror moral, no qual "podemos ver a divisão do mundo em vidas passíveis ou não passíveis de luto" (BUTLER, 2018, p. 53). No Brasil, como visto, o COVID-19 afetou diferencialmente a população brasileira. A classe trabalhadora, em sua heterogeneidade e interseccionalidade, torna-se alvo do projeto econômico excludente. Dito isso, compreendem-se as razões de 160 mil mortes não gerarem a comoção que o Norte Global geraria.

A partir de todo cenário delineado, a agudização da crise capitalista e o desmonte das políticas sociais impulsionadas pelo ideário neoliberal

\footnotetext{
${ }^{31}$ Matéria intitulada "Pessoas trans e LGBT+ negras e indígenas estão mais expostas ao impacto da covid-19, aponta pesquisa”. Disponível em: http://www.generonumero.media/lgbt-coronavirus/. Acesso em: 24/11/2020.
} 
articulam-se à expansão ideológica do conservadorismo, à reificação e a propagação do irracionalismo manipulada pela produção de mentiras em larga escala, pautadas no revisionismo histórico, na perseguição dos movimentos sociais e na crescente militarização da sociedade brasileira. Este movimento busca a aniquilação, repressão, intimidação, perseguição, criminalização e extermínio das diferenças, da diversidade e do próprio processo democrático que garantiu a eleição do Bolsonaro.

Considerando o debate da contemporaneidade e os paralelos entre a ascensão política da extrema direita atual e o fascismo da primeira metade do século XX, Badaró (2019) aponta o papel da crise e recessão econômica, o esgotamento do modelo de conciliação de classes, a atuação da pequena burguesia e dos setores médios, as manifestações multitudinárias, o caminho autocrático do golpe e a mobilizações das forças políticas, parlamentares e midiáticas.

Este cenário forma a base social para o fortalecimento de movimentos conservadores pautados pela antipolítica, isto é, "contrários a velha política" como alternativa de transformação para enfrentar a crise econômica através de um programa "austericida" de retirada de direitos, através das contrarreformas.

Em concordância com o autor, esses elementos elencados acima tornam difícil questionar a atribuição do adjetivo fascista ao que Bolsonaro e o movimento bolsonarista representa e propaga no seu projeto político, ainda que precisemos referenciar o prefixo "neo" para retratar as determinações do atual momento histórico. Por outro lado, deve-se assinalar que a eleição de um fascista não significa a imediata transposição a um regime político fascista, mas a adesão de um programa político econômico que flerta com as características gerais do fascismo histórico para garantir o sentido de classe na intervenção do Estado na economia (BADARÓ, 2019).

A fusão do neoconservadorismo e do neoliberalismo, expresso na Nova Direita, demonstra então que a democracia, a soberania política que funda os Estados modernos e a política social estão em xeque (BROWN, 2006). Ou, nos termos de Pereira (2020), estão em colapso, onde o poder está sendo expropriado por forças supraestatais globais a serviço do grande capital. 


\section{Considerações Finais}

Jair Bolsonaro é um presidente de extrema direita, cujo governo resulta em um ordenamento político autoritário e antidemocrático. $O$ bolsonarismo pode ser compreendido como um afinamento com a militarização da vida cotidiana, apresso ao Estado penal que exacerba punitivismo, na defesa do armamentismo e na retomada dos valores e da moral familiar.

Com uma apologia deliberada às variadas formas de violência, o discurso de inspiração neoconservadora, nacionalista e explicitamente fundamentalista religioso vincula-se aos valores da tradição e nas práticas arraigadas na sociedade brasileira, recuperando a base colonialista, autoritária e patrimonialista. Nesse contexto, a representação do conservadorismo e do reacionarismo aglutinam-se às forças ruralistas e fundamentalistas institucionalizadas historicamente no Poder Legislativo.

Inobstante, Judith Butler (2020, p. 11) indica que "a vida é um direito só dos privilegiados". Entre a resistência das ruas, o risco do isolamento social na pandemia e as alianças dos corpos passíveis de morte, o destino político do povo brasileiro segue em uma embarcação à deriva e exige pressa para juntar o que ficará das ruínas da jovem democracia brasileira. Todavia, o cenário internacional tem soprado ventos de esperança. Donald Trump foi recentemente derrotado nos Estados Unidos. No Chile, após intensos protestos, conseguiram derrubar a Constituição da ditadura de Pinochet por meio de plebiscito. Na Bolívia e Argentina, governos à esquerda foram eleitos.

Os poderes políticos têm celebrado o casamento do neoliberalismo com o neoconservadorismo, e sem dúvidas, essa é a força hegemônica que tem direcionado os caminhos e tomadas de decisão no Brasil. Todavia, é também nesse cenário que se expressa a contradição e a resistência, ao qual a comunidade LGBTI bateu recorde histórico ao eleger 73 representantes nas eleições municipais de $2020^{32}$, inclusive diversas pessoas trans foram

\footnotetext{
${ }^{32}$ Para ver mais: Eleições 2020: Brasil bate recorde histórico com mais de 70 LGBTIs eleitos. Disponível em: https://revistahibrida.com.br/2020/11/16/eleicoes-2020-brasil-bate-recorde-historico-commais-de-70-lgbtis-eleitos/ . Acesso em: 24/11/2020.
} 
candidatas com maior número de votos no ranking geral como Duda Salabert, Linda Brasil, Lorim de Valéria, Titia Chiba, Dandara e Tieta Melo. As candidaturas LGBTI somaram mais de 450.853 votos espalhados pelo país. É nesse sentido que "lá onde há poder há resistência" (FOUCAULT, 1988, p. 91).

O enfrentamento sistemático da ameaça neoconservadora em curso no país e na dinâmica social brasileira requer a organização de uma frente única da classe trabalhadora (LACERDA, 2020). Isto significa agregar a vinculação de classe a um projeto de luta unitária contra o projeto ultraneoliberal que atenta contra os direitos duramente conquistados, compreendendo que não uma oposição entre a classe social e as diversidades de gênero, sexual e étnicorraciais. 


\section{REFERÊNCIAS}

ANTUNES, Ricardo; PRAUN, Luci. A aposta nos escombros: reforma trabalhista e previdenciária - a dupla face de um mesmo projeto. Revista Jurídica Trabalho e Desenvolvimento Humano, Campinas, v. 2, n. 1, p. 56-81, 2019.

BARBOSA, A. L. N. de H; COSTA, J. S; HECKSHER, M. Mercado de trabalho e pandemia da covid-19: ampliação de desigualdades já existentes? 2020. Disponível em: http://repositorio. ipea.gov.br/handle/11058/10186. Acesso em: 10/11/2020.

BOSCHETTI, Ivanete. Assistência Social e Trabalho no Capitalismo. São Paulo: Cortez Editora, 2016.

BROWN, Wendy. American Nightmare: Neoliberalism, Neoconservatism and DeDemocratization. Political Theory, Vol. 34, No. 6 (December, 2006), p. 690-714.

BUTLER, Judith. Quadros de guerra: Quando a vida é passível de luto? Tradução de Sérgio Tadeu de Niemeyer Lamarão e Arnaldo Marques da Cunha; revisão de tradução de Marina Vargas; revisão técnica de Carla Rodrigues. - 4ª ed. - Rio de Janeiro: Civilização Brasileira, 2018.

BUTLER, Judith. Traços humanos na superfície do mundo. Rio de Janeiro: N-1 Edições, 2020. Disponível em: <https://www.n-1edicoes.org/textos/75>. Acesso em 08 nov. 2020.

CASSAL, Luan C. B. Um estudo entre ruínas: o programa Rio Sem Homofobia e a política LGBTI Fluminense. REBEH - Revista Brasileira de Estudos da Homocultura, 2018, Vol. 1, n 4, p. 124-162. Disponível em: < https://periodicoscientificos.ufmt.br/ojs/index.php/rebeh/article/ view/9203>. Acesso em: 10/11/2020.

CEPÊDA, Vera Alves. A Nova Direita no Brasil: contexto e matrizes conceituais. Mediações Revista de Ciências Sociais, Londrina, v. 23, n. 2, p. 75-122, maio/ago. 2018. Disponível em: <http://www.uel.br/revistas/uel/index.php/ mediacoes/article/view/34801/pdf>. Acesso em: $10 / 11 / 2020$.

CORRÊA, Sonia. Eleições brasileiras de 2018: a catástrofe perfeita? Sexuality Policy Watch, Rio de Janeiro, 12 nov. 2018.

FERNANDES, Florestan. Capitalismo dependente e classes sociais na América Latina. 4.ed.- rev. - São Paulo: Global, 2009.

FOUCAULT, Michel. História da sexualidade I: A vontade de saber, tradução de Maria Thereza da Costa Albuquerque e J. A. Guilhon Albuquerque. Rio de Janeiro, Edições Graal, 1988.

IRINEU, B. A.; OLIVEIRA, B. A. Um balanço das políticas públicas de trabalho, emprego e renda para população LGBT no Brasil e na Argentina (2004-2014). Revista Direitos Humanos e Democracia, Ano 8, nº 16, Jul./Dez. 2020.

IRINEU, Bruna A. et al. "O samba começou e fez convite ao tango para parceiro"? A arena LGBTI em tempos de ofensiva neoliberal e "cruzada antigênero" no Brasil e na Argentina. Humanidades \& Inovação. 2019, v. 6, n. 17, p. 255-270. 
IRINEU, Bruna Andrade. Nas tramas política pública LGBT no Brasil (2003-2015): um estudo crítico da experiência brasileira. EdUFMT: Cuiabá, 2019.

JUNQUEIRA, Rogério Diniz. A invenção da "ideologia de gênero": a emergência de um cenário político-discursivo e a elaboração de uma retórica reacionária antigênero. Revista Psicologia Política, v.18, n.43, São Paulo, p. 449-502, set./dez. 2018.

LACERDA, Milena Carlos de. Colorindo o Marxismo: considerações sobre o materialismo e as lutas LGBTI no capitalismo. REBEH, Vol. 03, N. 10, Abr. - Jun., 2020. p. 191-213. Disponível em: < https://periodicoscientificos.ufmt.br/ojs/index.php/rebeh/article/view/10621>. Acesso em: $31 / 12 / 2020$.

MATTOS, Marcelo Badaró. "Mais que uma analogia: análises clássicas sobre o fascismo histórico e o Brasil de Bolsonaro" in CILAGHI, J. e DEMIER, F. (orgs). O neofascismo no poder (ano I): análises críticas sobre o governo Bolsonaro. Rio de Janeiro: Consequência, 2019, p. $19-45$.

MELO, Thálita M. Pistas para uma cartografia performativa da "Nova Direita”(2015-2019). Rev. Bras. Estud. Presença, Porto Alegre, v.9, n.4, 2019. Disponível em: <http://seer.ufrgs. br/presenca>. Acesso em: 10/11/2020.

MISKOLCI, Richard; PEREIRA, Pedro Paulo Gomes. Educação e Saúde em disputa: movimentos anti-igualitários e políticas públicas. Interface (Botucatu), Botucatu, v. 23, e180353, 2019. Disponível em: <http://www.scielo.br/scielo.php?script=sci_arttext\&pid=S1414$32832019000100400 \& \operatorname{lng}=e n \& n r m=i s o>$. Acesso em: 10/11/2020.

OLIVEIRA, Brendhon Andrade. A cultura conjugal, familismo jurídico e judicialização de direitos LGBTI no Brasil. REBEH, Vol. 03, N. 10, Abr. - Jun., 2020. p. 7-34. Disponível em: <https://periodicoscientificos.ufmt.br/ojs/index.php/rebeh/article/view/11117>. Acesso em: $31 / 12 / 2020$.

PEREIRA, Potyara A. P. Ascensão da nova direita e o colapso da soberania política: transfigurações da política social. Cortez: São Paulo, 2020.

SOUZA, DIEGO O. As dimensões da precarização do trabalho em face da pandemia de Covid-19. Trabalho, Educação e Saúde, v. 19, 2021, e00311143. DOI: 10.1590/1981-7746-sol00311

TOITIO, Rafael. A luta pela diversidade sexual e de gênero diante do Estado Capitalista: o que a atual crise política tem a nos ensinar? Revista Margem Esquerda, n 33, São Paulo: Boitempo, 2019, p. 32-37.

WOOD, Ellen. Democracia contra capitalismo: a renovação do materialismo histórico. São Paulo: Boitempo, 2003, p. 27-49. 


\title{
A CONSTRUÇÃO DA CIDADANIA E DAS POLIITICAS PÚBLICAS PARA LGBTS NO CENTRO-OESTE DO BRASIL ${ }^{33}$
}

\author{
Moisés Lopes
}

O presente capítulo busca construir uma reflexão sobre a construção de Políticas Públicas e ações governamentais direcionadas a Lésbicas, Gays, Bissexuais, Transexuais e Travestis (LGBTs) no Centro-Oeste do Brasil. É importante ressaltar que trata-se de um esforço de apresentação de uma região com a segunda maior extensão territorial (Área de $1.606 \mathrm{mil} / \mathrm{km}^{2}$ ), com uma população de 15,88 milhões de habitantes - considerada a menos populosa do Brasil -, com a segunda menor densidade populacional do país e que concentra uma das maiores diversidades socioculturais brasileiras com a presença de mais de 50 povos indígenas segundo a Fundação Nacional do Índio (dados de 2010) e mais de 140 comunidades quilombolas registradas na Fundação Cultural Palmares (dados de 2018).

É importante também ressaltar que cerca de metade da população da região (7 milhões de habitantes) está concentrada em duas grandes regiões metropolitanas que distam cerca de $200 \mathrm{kms}$ uma da outra, quais sejam: Região Integrada do Distrito Federal e Entorno (4,5 milhões de habitantes) e a Região Metropolitana de Goiânia (2,5 milhões de habitantes). A outra metade da população da região, cerca de 8 milhões, está dispersa em cidades nos 3

\footnotetext{
${ }^{33}$ Fragmentos deste capítulo foram publicadas em versões preliminares de artigos anteriores: LOPES, Moisés A. S.; ARAGUSKU, Henrique A. "Preconceito, Discriminação e Cidadania LGBT: Políticas Públicas em Mato Grosso e no Brasil”. ACENO - Revista de Antropologia do Centro-Oeste. Vol. 3, n. 5, 2016, p. 242-258.; LOPES, Moisés. "A construção de Políticas Públicas para pessoas LGBTI+ no Centro-Oeste do Brasil: Uma visão exploratória”. In: Artur Zimerman. (Org.). Desigualdade Regional e as Políticas Públicas: Políticas LGBTI+. 1ed.Santo André: Universidade Federal do ABC, 2019, v. 14, p. 38-53. LOPES, Moisés. "Políticas Públicas de Saúde para Travestis e Transexuais em Mato Grosso: Problematizações preliminares”. In: Sonia Lourenço; Marcos Aurélio da Silva; Moisés Lopes. (Org.). Dissidências, alteridades, poder e políticas: antropologias no plural. 1ed. Florianópolis: Editora da UFSC, 2020, v. 1, p. 83-98.
} 
estados (Goiás, Mato Grosso e Mato Grosso do Sul), que, como dito acima, ocupam a segunda maior extensão territorial do país.

Estas características são extremamente importantes para se pensar a criação e o estabelecimento de políticas públicas para LGBTs na região. E, também, algumas contradições como por exemplo o fato da maior cidade da região, Brasília (mais de 3 milhões de habitantes), só ter criado Políticas Públicas para LGBTs a partir de 2015, e o estado com a menor população absoluta e relativa, Mato Grosso, já ter desde 1986 em sua Constituição Estadual a vedação à discriminação por orientação sexual.

Como apontei anteriormente, reitero trata-se de uma visão exploratória, preliminar e baseada em um esforço de sistematização de dados dispersos em diversos meios (redes sociais, documentos governamentais, artigos científicos escassos, sites de ONGs e governamentais) sobre a constituição de políticas públicas em uma região com enorme diversidade sociocultural, econômica e política. Neste sentido, apresento neste texto, em um primeiro momento, a estratégia metodológica que utilizei para o levantamento dos dados que analiso ressaltando a dificuldade para acessar tais dados. Em um segundo momento, parto das discussões sobre a constituição das políticas públicas para a população de Lésbicas, Gays, Bissexuais, Travestis e Transgêneros (LGBTs) no Brasil com o intuito de ressaltar sua influência na construção das políticas públicas no cenário da região centro-oeste. Por fim, apresento o caso de Mato Grosso, foco de minhas investigações desenvolvidas nos últimos anos a partir das pesquisas intituladas: Homossexualidades, Preconceitos e Discriminações: a construção social do gênero no universo LGBT da baixada cuiabana (financiado pelo MCT/CNPq/ FAPEMAT) desenvolvido entre os anos de 2011 e 2015; e Violências, resistências e subjetividades de travestis e transexuais na Baixada Cuiabana, que realizei em meu estágio de pós-doutorado junto ao Programa de Pós-graduação em Antropologia Social da Universidade Federal de Santa Catarina (PPGAS/UFSC), entre agosto de 2017 e agosto de 2018.

\section{Estratégias metodológicas}

Como citado anteriormente, este artigo representa um esforço acumulado de pesquisas desenvolvidas desde o ano de 2011, quando ao chegar em Cuiabá, notei a quase ausência de pesquisas sistemáticas sobre a construção das sociabilidades, da cidadania, dos movimentos LGBTs 
e das Políticas Públicas para LGBTs no estado de Mato Grosso. Assim, buscando dar conta da diversidade destas experiências dei início a pesquisa Homossexualidades, Preconceitos e Discriminações: a construção social do gênero no universo LGBT da baixada cuiabana (financiado pelo MCT/CNPq/ FAPEMAT), que utilizava uma diversidade de estratégias metodológicas que envolviam o levantamento de fontes de dados em jornais, revistas, sites institucionais ou de notícias; entrevistas com ativistas LGBTs do estado de Mato Grosso; observação participante em eventos e reuniões, no qual se encontravam atores do cenário LGBT do estado. Os dados resultantes desta pesquisa constituíram um banco de dados imenso que ainda está em processo de organização, catalogação e análise mas que já resultaram em uma série de artigos científicos ${ }^{34}$; uma exposição fotográfica realizada em 2019 no Museu Rondon de Etnologia e Arqueologia ${ }^{35}$; diversas apresentações de trabalho em diversos eventos; e também, resultaram na elaboração do projeto de pesquisa Violências, resistências e subjetividades de travestis e transexuais na Baixada Cuiabana, com o qual realizei meu estágio de pósdoutorado junto ao Programa de Pós-graduação em Antropologia Social da Universidade Federal de Santa Catarina (PPGAS/UFSC), entre agosto de 2017 e agosto de 2018 e que continua em desenvolvimento até hoje.

Este último projeto que venho desenvolvendo junto ao Núcleo de Antropologia e Saberes Plurais (NAPlus), na Universidade Federal do Mato Grosso (UFMT), tem como foco de pesquisa analisar as trajetórias de transexuais e travestis pelo sistema de saúde em busca do processo transexualizador, as reivindicações que envolvem a criação de um ambulatório transexual, bem como compreender a constituição da

\footnotetext{
${ }^{34}$ LOPES, Moisés A. S.; SILVA, Jéssica C. A. 2015. "De chapa e cruz", "pau rodados” aqui "tem de um tudo". Da movimentação de homossexuais ao movimento LGBT de Cuiabá e Mato Grosso. ACENO - Revista de Antropologia do Centro-Oeste. Vol. 2, nº 4, p. 41-54. LOPES, Moisés A. S.; ARAGUSUKU, Henrique A. Preconceito, "Discriminação e Cidadania LGBT: Políticas Públicas em Mato Grosso e no Brasil". ACENO - Revista de Antropologia do Centro-Oeste. Vol. 3, n. 5, 2016, p. 242-258. LOPES, Moisés. "Algumas observações sobre as homossexualidades em 'Contextos Interioranos': Lançando questões de 'Fora dos Centros'”. Amazônica: Revista de Antropologia, v. 8, p. 24-37, 2017. LOPES, Moisés; ARAGUSUKU, H. A. "Políticas públicas e cidadania LGBT em Mato Grosso: Uma década de avanços e retrocessos (2007-2017)". SEXUALIDAD, SALUD Y SOCIEDAD. Rio de Janeiro, p. 147-171, 2018. LOPES, Moisés; SILVA, Marcos Aurélio. "Festa, política e o corpo na rua: Uma antropologia visual da Parada da Diversidade de Cuiabá nos 50 anos de Stonewall". Revista Brasileira de Estudos da Homocultura - REBEH, v. 02, p. 180-197, 2019. Entre outros.

${ }^{35}$ LOPES, Moisés; SILVA, Marcos Aurélio. "Festa, política e o Corpo na Rua: uma antropologia visual da Parada da Diversidade de Cuiabá, nos 50 anos de Stonewall”. 2019.
} 
subjetividade e da identidade travesti e transexual, a construção das performances de gênero e a construção de diferenças, hierarquias, preconceitos, discriminações e violências no contexto mato-grossense. Para o desenvolvimento desta pesquisa venho me valendo de uma dupla posição: seja como ativista, seja como pesquisador. Na primeira delas, ocupo o lugar de Conselheiro do Conselho Municipal de Atenção à Diversidade Sexual de Cuiabá (CMADS), representando a Universidade Federal de Mato Grosso desde a criação deste conselho em 2014, por meio da Lei $n^{\circ} 5.795$ de 04 de abril de 2014 (CUIABÁ, 2014), como um dentre os 15 membros: sendo cinco representantes do Poder Público Municipal; cinco representantes da comunidade LGBT; um representante da Comissão da Diversidade da Seção da OAB/MT; um representante do Ministério Público do Estado de Mato Grosso; um representante da Defensoria Pública do Estado de Mato Grosso; um representante da Câmara Municipal; e, um representante de Instituição Pública ligada à pesquisa da violência contra a população LGBT (posição que ocupo). E, meu segundo posicionamento, diz respeito ao lugar de pesquisador-antropólogo.

Deste modo, longe de ter esgotado a análise do acervo constituído durante estes anos, este artigo tem como fim apresentar uma reorganização de dados levantados no decurso da última década, bem como desenvolver o aprofundamento em certas questões analíticas. Assim, para o desenvolvimento deste artigo me amparei inicialmente em um levantamento realizado no estado de Mato Grosso sobre as Políticas Públicas para LGBTs por artigos decorrentes destas pesquisas em especial (LOPES; ARAGUSUKU, 2016). E, também me inspirei no projeto de pesquisa Políticas Públicas para a população LGBT no Brasil: um mapeamento crítico preliminar (MELLO; MAROJA; BRITO, 2010), realizado pelo Ser-Tão, Núcleo de Estudos e Pesquisas em Gênero e Sexualidade, da Universidade Federal de Goiás, com apoio financeiro da Secretaria de Direitos Humanos da Presidência da República (SDH/PR). Entretanto, diferentemente das pesquisas supracitadas, busco nessa análise desenvolver um estudo exploratório, panorâmico e de sistematização das Políticas Públicas para LGBTs em âmbito regional - o que se diferenciaria da pesquisa desenvolvida por mim em âmbito estadual; e, não desenvolverei uma análise da gestão, da implementação ou das fragilidades destas Políticas Públicas, foco da pesquisa de Mello, Maroja e Brito.

Neste sentido, é importante destacar que uma análise sobre políticas públicas pode ser realizada a partir de diferentes enfoques, perspectivas 
teóricas e metodológicas, sendo privilegiada neste texto o levantamento das ações do poder público em nível estadual das políticas implementadas na região Centro-Oeste. É importante ressaltar que não busco a construção de uma análise operativa de políticas públicas, pouco me aprofundando em aspectos da gestão, das fragilidades e da efetividade da execução dessas políticas; se trata de um estudo de caráter exploratório, de visualização panorâmica e sistematização de um campo ainda pouco estudado.

Para o levantamento dos dados, foi realizada uma ampla revisão bibliográfica de produções acadêmicas vinculadas à questão central, bem como um levantamento documental, com informações referentes às políticas públicas LGBT na região Centro-Oeste que foram buscadas principalmente de páginas da internet: portais de notícias, sítios governamentais, publicações no diário oficial, informações vinculadas nas redes sociais e blogs, etc. Foram buscados, fundamentalmente, documentos e relatórios governamentais, decretos do poder executivo e projetos legislativos, estatutos e regulamentos de políticas públicas, notícias referentes a políticas sexuais e movimento LGBT no Centro-Oeste, entre outros materiais de referência.

E é importante ressaltar a dificuldade de acesso a tais informações no âmbito dos estados, devido a algumas questões: 1 - inexistência de qualquer sistematização prévia das políticas públicas para LGBTs criadas ou em criação no âmbito dos estados, seja por parte do movimento, seja por parte do poder público; 2 - inexistente ou pouca publicização das experiências de políticas públicas LGBTs criadas no âmbito dos estados; 3 - falta de canais oficiais e de respostas dos canais já existentes a questionamentos sobre tais dados; 4 - inexistência de sites e portais com documentos e dados consolidados sobre as políticas públicas para LGBTs nos estados. Deste modo, os dados apresentados não são de modo algum conclusivos, visto que há projetos de lei, resoluções, portarias ou políticas públicas que mesmo sendo citados, não se conseguiu verificar o estágio de implementação/aprovação/regulamentação e alguns que não serão citados, pelo simples fato de não se ter conseguido acesso a informações de sua existência. Apesar disso, este texto apresenta uma visão bastante panorâmica e sistemática das políticas públicas no centrooeste do Brasil, o que permite compreender a realidade desta região. Mas, para compreender a realidade da região, é necessário em um primeiro momento se reportar à construção das Políticas Públicas para LGBTs no 
Brasil, com o fim de ressaltar como estas influenciaram na constituição destas em âmbito regional e local, e este é o foco da seção seguinte.

\section{Políticas Públicas para LGBTs no Brasil: algumas questões}

Podemos utilizar como ponto de partida para debater as questões das políticas LGBT em âmbito nacional a Constituição Federal de 1988, que consolidou o compromisso do Estado em garantir a universalização de direitos sociais, como saúde e educação. A Constituição de 88 , tomada como reflexo da configuração de forças existentes em que diversos movimentos sociais organizados disputavam "o rumo" do Estado brasileiro, entretanto, não se mostrou favorável para o movimento LGBT, que apesar de pressionar o Congresso Nacional, não conseguiu incluir o combate à discriminação por orientação sexual na Constituição.

Efetivamente, as primeiras ações direcionadas à população LGBT vieram do Ministério da Saúde, com o compromisso do Estado brasileiro firmado na Constituição de 88, em garantir a promoção e universalização do acesso à saúde à população, como por exemplo, no apoio financeiro do Governo Federal, através do Programa Nacional de DST/AIDS; e, para a realização da Conferência Regional da Associação de Lésbicas e Gays em 1995 no Rio de Janeiro.

Para além do âmbito da saúde, apenas no final da década de 90 foi implementada a primeira política pública LGBT no Brasil voltada para a segurança pública, o Disque Defesa Homossexual (DDH) em 1999 (CARRARA; RAMOS, 2006). E, em 2001, tivemos as primeiras ações voltadas para a promoção de cidadania e direitos humanos com a criação do Conselho Nacional de Combate à Discriminação (CNCD), vinculado ao Ministério da Justiça (MELLO; MAROJA; BRITO, 2012). O compromisso do Governo Federal de combater a discriminação por orientação sexual volta a aparecer no II Programa Nacional de Direitos Humanos de 2002, com quinze ações propostas a serem implementadas, entre elas, a regulamentação da parceria civil registrada e a criação de programas de combate à violência homofóbica. Tivemos também a realização da I Conferência Nacional de Políticas Públicas para GLBT em 2008, e a II Conferência Nacional LGBT em 2011. Estas conferências foram iniciativas inéditas do poder público, mobilizando um número significativo de pessoas (pesquisadores, militantes, funcionários 
públicos, políticos etc.), com a realização de Conferências Estaduais e encontros regionais em todos os Estados do Brasil.

Assim, as principais ações do Governo Federal que dão suporte para a implementação e execução de políticas de combate à LGBTfobia, nos seus âmbitos específicos, são:

- Programa Brasil Sem Homofobia (2004);

- Plano Nacional de Cidadania e Direitos Humanos LGBT (2009);

- Conselho Nacional de Combate à Discriminação LGBT (2010);

- II Conferência Nacional de Políticas Públicas e Direitos Humanos de LGBT (2011);

E dentre as políticas mais recentes, que tiveram um impacto relativo sobre a agenda nacional de políticas públicas LGBT, não podemos deixar de citar a criação do Sistema Nacional de Promoção de Direitos e Enfrentamento à Violência Contra LGBT (2013); do Comitê Interministerial de Enfrentamento à Violência Contra LGBT (2015); e da realização da III Conferência Nacional de Políticas Públicas de LGBT (2016).

É importante citarmos aqui as principais ações realizadas pelo Poder Executivo brasileiro desde a publicação do Brasil Sem Homofobia em 2004. No campo da saúde, ocorreu a publicação do Plano Nacional de Saúde Integrada de LGBT em 2008, e a criação da Comissão Intersetorial de Saúde da População de LGBT no âmbito do Conselho Nacional de Saúde. Na área da educação, o Governo Federal realizou programas de capacitação de professores e apoio à criação de material que discutisse questões referentes às sexualidades e à homofobia. Ainda no âmbito da Secretaria de Direitos Humanos da Presidência da República, ocorreu a publicação dos "Relatório sobre Violência Homofóbica no Brasil: ano de 2011" e do "Relatório sobre Violência Homofóbica no Brasil: ano de 2012", que demonstram o número e as características de ataques à LGBTS em todo o país. É importante ressaltar, no entanto, que estes números demonstram apenas uma realidade superficial, já que muitos casos não são denunciados ou não chegam às estatísticas do Governo Federal. Em 2009, houve também a publicação do Plano Nacional de Direitos Humanos 3 (PNDH 3), que contempla ações do Governo Federal direcionadas à população LGBT. E, como uma das últimas ações, citamos a promulgação da Resolução do Conselho Nacional de 
Combate à Discriminação, de 15 de abril de 2014, que visa assegurar direitos para LGBTs em presídios.

No âmbito do Poder Judiciário, destaco o reconhecimento da união estável de pessoas do mesmo sexo, pelo Supremo Tribunal de Justiça em 2011 e, de forma complementar, a publicação da Resolução Nº 175 de 14 de maio de 2013 do Conselho Nacional de Justiça que veda a recusa da habilitação para a celebração de casamento civil ou de conversão de união estável em casamento entre pessoas do mesmo sexo. A partir dessas medidas, a união estável e o casamento civil de pessoas do mesmo sexo são oficializados no País por meio do Poder Judiciário. Em abril de 2018, o Supremo Tribunal Federal (STF) autoriza pessoas trans a alterarem o nome no registro civil sem a necessidade de cirurgia de redesignação sexual ou decisão judicial, alteração esta que pode ser feita diretamente no cartório mais próximo. Já em junho de 2019, o STF determinou que a discriminação contra pessoas LGBT seja enquadrada nos crimes previstos na Lei $n^{\circ}$ 7716/1989 (Lei do Racismo), prevendo penas de até 5 anos de prisão, até que uma norma específica seja aprovada pelo Congresso Nacional. E, já em maio de 2020, o STF, declarou inconstitucional e suspendeu as normas do Ministério da Saúde e da Anvisa que exigiam aos homossexuais a abstinência sexual de um ano para doarem sangue.

As políticas públicas acima citadas, que se desenvolveram nas últimas décadas no Estado brasileiro, representaram grandes avanços na possibilidade de transformação da realidade de violência e discriminação às quais os LGBTs estão sujeitos no Brasil. E, apesar de apontarem um cenário promissor, infelizmente no âmbito do Governo Federal (mas também em âmbitos estaduais e municipais como mostrarei abaixo), estas, por força de pressões de setores conservadores da sociedade, foram implementadas parcialmente ou mesmo sequer foram colocadas em funcionamento e, nos últimos anos, com a eleição do Presidente Bolsonaro, tem sido desmontadas gradativamente, como por exemplo com a publicação do decreto $n^{\circ} 9.883 \mathrm{em}$ abril de 2019, que extingue o Conselho Nacional de Combate à Discriminação (CNCD/LGBT), o recria novamente em junho, por meio de outro decreto assinado pelo vice-presidente Mourão, mas em seu texto não cita nenhuma vez a pauta LGBT+ como de competência do conselho e também diminui a quantidade de membros, de 30 para sete, sendo quatro membros do governo e três da sociedade civil. 
Como apontam Mello, Maroja e Brito (2012), vivemos uma "ausência de arcabouço jurídico" que legitime a formulação e a implementação de políticas públicas voltadas para as populações LGBTs. Os documentos que preveem ações direcionadas à população LGBT existem na forma de "atos normativos secundários" advindos do Poder Executivo (decretos, resoluções, recomendações), ou de maneira totalmente informal, como ocorreu com o Brasil Sem Homofobia e o Plano Nacional LGBT. Em decorrência disso, surge uma dificuldade em assegurar a continuidade e a efetividade dos programas, sujeitos à vontade de governos e à falta de planejamento e dotação orçamentária. Como exemplo, temos os Centros em Direitos Humanos e Combate a Homofobia, política iniciada pelo Governo Federal em 2007, que deixa de existir com o fim dos recursos federais ou acaba sendo realocada para Secretarias do Estado (FROEMMING; IRINEU; NAVAS, 2010).

Como ressaltei, a maior dificuldade para a implementação de políticas públicas para os grupos LGBTs advém do entrave na aprovação de legislações, nos três níveis de governo (municipal, estadual/distrital e federal), com ênfase para uma maior dificuldade no Congresso Nacional, que não aprovou até o momento nenhuma lei direcionada a LGBTs. Isso decorre do cenário político conservador do Poder Legislativo, que conforme apontado anteriormente, vem se acentuando. Os maiores avanços vieram do Poder Judiciário.

\section{Políticas Públicas para LGBTs no Centro-Oeste}

Neste momento do texto, com o objetivo de analisar a realidade da região, será realizada a apresentação dos dados de modo separado por área para que seja possível também estabelecer comparações entre os estados da região.

\section{Centro de Referência em Direitos Humanos/ LGBTs}

A constituição das políticas públicas LGBT na região Centro-Oeste está diretamente relacionada com as políticas impulsionadas pelo Governo Federal a partir de 2004, especialmente a partir da criação dos Centros de Referência LGBT, em todo o Brasil, como uma das ações do Programa Brasil Sem Homofobia (BSH) - primeiro documento governamental destinado 
exclusivamente à sistematização de ações e políticas destinadas ao público LGBT no Brasil.

Mato Grosso do Sul teve o primeiro centro de referência da região, o CENTRHO ${ }^{36}$ criado em 2006 em Campo Grande pelo governo do Estado dentro da Secretaria de Estado de Direitos Humanos, Assistência Social e Trabalho e está em funcionamento até hoje; em 2007 foi criado um outro centro de referência no estado, em Dourados, sob gestão da ONG Associação de Gays, Lésbicas e Transgêneros de Dourados e teve o encerramento de suas atividades em 2009 com o fim do convênio com a Secretaria de Direitos Humanos da Presidência da República (SDH/PR). No mesmo ano (em 2007) no estado de Mato Grosso, a ONG Vida Ativa instituiu um centro de referência em Rondonópolis, que encerrou as atividades também em 2009 com o encerramento das atividades da ONG e o fim do convênio com a SDH/PR. Já em 2008, o Governo do Estado de Mato Grosso criou um Centro de Referência de Combate à Homofobia, que em 2012 foi incorporado ao Centro de Direitos Humanos das Populações Vulneráveis e continua em funcionamento. No estado de Goiás, em sua capital, o Governo do Estado criou, em 2009, o Centro de Referência de Promoção da Igualdade, que busca atender as populações vulneráveis. Já no DF, somente em 2015 o governo do Estado criou o Centro de Referência Especializado da Diversidade Sexual, Religiosa e Racial.

Como vemos, os Centros de Referência em Direitos Humanos LGBT (CR-LGBT) na região Centro-Oeste foram criados a partir de 2006, por meio de financiamento público obtido via edital da Secretaria Especial de Direitos Humanos da Presidência da República (SEDH/PR), lançado em 2005. Esse edital auxiliou a criação de CR-LGBT em todo o país, construindo parcerias com entidades da sociedade civil (ONGs LGBT) e órgãos públicos estaduais e municipais, sendo uma ação do Brasil Sem Homofobia. No entanto, tal financiamento foi momentâneo, resultando no fechamento de praticamente todos os CR-LGBT por falta de recursos financeiros, sobretudo aqueles vinculados a ONGs (FROEMMING; IRINEU; NAVAS, 2010). Alguns foram transformados em Centros de Referência em Direitos Humanos de Populações Vulneráveis, atendendo um público muito mais amplo, como aconteceu em Cuiabá.

${ }^{36}$ Centro de Referência em Direitos Humanos de Prevenção e Combate à Homofobia. 


\section{Conferências Estaduais/ Distrital LGBTs}

Temos, como um dos principais espaços de diálogo entre Estado e sociedade civil com o objetivo de construção de políticas públicas, as Conferências Estaduais/ Distrital LGBT de políticas públicas. Ocorreram, ao todo, três conferências estaduais/ distrital LGBT na região Centro-Oeste (2008, 2011 e 2016), realizadas a partir da convocação das conferências nacionais pelo Governo Federal. As conferências são certamente importantes eventos, pois reúnem diversos atores sociais envolvidos na elaboração, implementação e execução de políticas públicas. Podemos localizá-las como um espaço de diálogo e síntese entre ativistas dos movimentos LGBT, servidores/as e gestores/as públicos, pesquisadoras/es no campo da diversidade sexual e de gênero, usuários/as de serviços públicos e comunidade LGBT.

Em todos os três estados e no DF foram realizadas as três Conferências Estaduais ou Distritais LGBTs nos anos de 2008, 2011 e 2016. É importante ressaltar aqui que não consegui obter informações mais extensas sobre as Conferências Estaduais/Distritais e suas etapas prévias, ou seja, Conferências municipais ou regionais, visto que os Anais e os documentos finais destas conferências não se tornaram públicos e disponíveis para consulta na internet. A única Conferência Estadual que teve os Anais publicados foi a da Segunda Conferência Estadual LGBT de Goiás que foi realizada entre os dias 20 e 22 de outubro de 2011.

\section{Conselho LGBT}

Os conselhos LGBTs são espaços de discussão e deliberação política, divididos de forma paritária entre sociedade civil e poder público, com o objetivo de elaboração de políticas públicas e controle social, bem como, podem-se constituir como um importante espaço de pressão social e articulação dos movimentos LGBT nos estados. É importante ressaltar que, para além do conselho específico, os coletivos LGBT também podem possuir inserção em outros conselhos estaduais e municipais, como os de educação, de saúde e de mulheres, mas não foi objetivo desta pesquisa levantar estes espaços de articulação, me centrando apenas nos Conselhos específicos.

Em 2008 foi aprovada a criação do Conselho Estadual de LGBT em Goiás, por meio do decreto $n^{\circ} 6855$ de $31 / 12 / 2008$ e reestabelecido pelo decreto $n^{\circ}$ 
7428 de 16/08/2011. Já em 2011, foi criado o Conselho Estadual da Diversidade Sexual (decreto 13.266 de 21/09/2011) em Mato Grosso do Sul. Ambos estão em funcionamento. Em Mato Grosso, a criação do Conselho Estadual LGBT passou por diversos problemas e segue sem existir efetivamente, depois da publicação de decreto em setembro de 2015 pelo governador do Estado, teve o decreto derrubado no mês seguinte pela Assembleia Legislativa. Já no DF, o Conselho Distrital de Promoção dos Direitos Humanos e Cidadania de pessoas LGBT foi criado por decreto n³8.292 de 23 de junho de 2017 e segue em funcionamento. O estado de Mato Grosso não tem até hoje seu Conselho Estadual LGBT, mas tem o Conselho Municipal de Atenção à Diversidade Sexual em funcionamento que foi criado em 2014. Já Goiânia propôs a criação do Conselho Municipal dos Direitos Humanos de LGBTs, mas teve seu projeto rejeitado em 12 de julho de 2017.

Como vemos acima, excetuando-se o estado de Mato Grosso, todos os outros estados da região Centro-Oeste possuem Conselhos Estaduais/ Distrital LGBTs. No caso de Mato Grosso, em setembro de 2015, foi publicado o decreto governamental de criação do Conselho Estadual LGBT, sendo um grande avanço para a construção de políticas públicas no estado. Entretanto, em menos de um mês, a Assembleia Legislativa aprovou a derrubada do decreto, a partir da pressão de grupos conservadores cristãos (católicos e evangélicos), demarcando um momento bastante desfavorável para a criação de políticas LGBT.

\section{Políticas Públicas de Saúde}

Até 2004 , as políticas de saúde para as populações LGBT se concretizaram unicamente por meio de projetos e ações pontuais, principalmente vinculadas à prevenção de DST/AIDS e ao apoio a pessoas vivendo com HIV/AIDS (PVHA), ou se centravam na patologização das identidades de travestis e transexuais associando estas expressões a ideia de transtorno de identidade de gênero. Se baseavam assim em um discurso de patologização se constituindo em políticas parciais e paliativas baseadas nos pares: AIDS/ homossexualidade ou transexualidade/transtorno de identidade de gênero.

A partir de 2004, com a criação do Comitê Técnico de Saúde da População LGBT, começa-se a discutir a atenção integral à saúde reconhecendo que a discriminação por orientação sexual e identidade de gênero afeta na 
determinação social da saúde, no processo de sofrimento/adoecimento resultante do preconceito e do estigma social a que está exposta a população LGBT, isso aliado a outros marcadores sociais da diferença como desemprego, moradia, classe social, educação, lazer, cultura afetam na qualidade de vida e da saúde dos LGBTs. Discussões que redundam em 2011 na criação da primeira versão da Política Nacional de Saúde Integral de LGBTs.

Nos estados da região Centro-Oeste, ao longo dos últimos anos, as políticas de saúde para as populações LGBT se concretizaram unicamente por meio de projetos e ações pontuais, principalmente vinculadas à prevenção de DST/AIDS, ao apoio a pessoas vivendo com HIV/AIDS (PVHA) e a realização de eventos, capacitações e ações de conscientização promovidas pelos CR-LGBT e pelas ONGs - em muitos momentos, com financiamento governamental.

\section{Políticas Públicas de Segurança}

Considerada uma das principais demandas do movimento LGBT brasileiro, as políticas de segurança pública para esse grupo só tiveram uma primeira formulação em 1999, com a criação da primeira política pública LGBT, o Disque Defesa Homossexual, no município do Rio de Janeiro (CARRARA; RAMOS, 2006). No âmbito federal, apesar de respaldada pela própria Constituição Federal que assegura e reconhece a segurança como um dos direitos individuais fundamentais e como um dever do Estado, não há nenhuma legislação, havendo projetos e programas que procura(va)m minimizar os impactos das violências sofridas pela população LGBT. No âmbito dos estados da região Centro-Oeste, temos o seguinte quadro: 


\begin{tabular}{|c|c|c|c|}
\hline Estado & Órgão & Tema da Política & $\begin{array}{l}\text { Ano de } \\
\text { Criação }\end{array}$ \\
\hline \multirow{6}{*}{ MT } & Centro de Referência LGBT & $\begin{array}{l}\text { Pacto de Conduta entre as } \\
\text { profissionais do sexo s e agentes } \\
\text { de Segurança Pública de MT. }\end{array}$ & 2008 \\
\hline & $\begin{array}{l}\text { Secretaria de Estado de } \\
\text { Segurança Pública }\end{array}$ & $\begin{array}{l}\text { Criação do Grupo Estadual } \\
\text { de Combate aos Crimes de } \\
\text { Homofobia (GECCH). }\end{array}$ & 2012 \\
\hline & $\begin{array}{l}\text { Secretaria de Estado de } \\
\text { Segurança Pública }\end{array}$ & $\begin{array}{c}\text { Portaria de regulamentação do } \\
\text { uso do nome social de travestis } \\
\text { e transexuais nos Boletins de } \\
\text { Ocorrência. }\end{array}$ & 2010 \\
\hline & $\begin{array}{l}\text { Secretaria de Estado de } \\
\text { Segurança Pública }\end{array}$ & $\begin{array}{l}\text { Portaria de regulamentação do } \\
\text { campo "motivação homofobia" } \\
\text { nos Boletins de Ocorrência. }\end{array}$ & 2009 \\
\hline & $\begin{array}{l}\text { Secretaria de Estado de } \\
\text { Segurança Pública }\end{array}$ & $\begin{array}{l}\text { Portaria de regulamentação da } \\
\text { inserção de orientação sexual nos } \\
\text { Boletins de Ocorrência. }\end{array}$ & 2016 \\
\hline & $\begin{array}{l}\text { Secretaria de Estado de } \\
\text { Segurança Pública }\end{array}$ & $\begin{array}{l}\text { Estabelece parâmetros de } \\
\text { acolhimento e atendimento à } \\
\text { população LGBT e cria espaços } \\
\text { de convivência no Sistema } \\
\text { Penitenciário. }\end{array}$ & 2017 \\
\hline \multirow[b]{2}{*}{ MS } & $\begin{array}{l}\text { Governo do Estado de Mato } \\
\text { Grosso do Sul }\end{array}$ & $\begin{array}{l}\text { Lei Estadual } n^{\circ} 3157 / 2005 \\
\text { - Dispõe sobre medidas de } \\
\text { combate à discriminação devido à } \\
\text { orientação sexual }\end{array}$ & 2005 \\
\hline & $\begin{array}{l}\text { Governo do Estado de Mato } \\
\text { Grosso do Sul }\end{array}$ & $\begin{array}{l}\text { Decreto Estadual } n^{\circ} 12.212 / 2006 \\
\text { - Regulamenta a Lei Estadual } n^{\circ} \\
3157 / 2005\end{array}$ & 2006 \\
\hline GO & \multicolumn{3}{|c|}{$\begin{array}{l}\text { Não foram encontradas notícias de Políticas Públicas na área de segurança para } \\
\text { a população LGBT no Estado. }\end{array}$} \\
\hline \multirow[b]{2}{*}{ DF } & Governo do DF & $\begin{array}{c}\text { Decreto n } 37.069 \text { de 21/01/2016 } \\
\text { - Criação da Delegacia Especial } \\
\text { de Repressão aos Crimes por } \\
\text { Discriminação Racial, religiosa } \\
\text { ou por Orientação Sexual, ou } \\
\text { contra a Pessoa Idosa ou com } \\
\text { Deficiência. }\end{array}$ & 2016 \\
\hline & Governo do DF & $\begin{array}{l}\text { Lei } \mathrm{n}^{\circ} 5835 \text { de } 11 / 04 / 2017 \text { - } \\
\text { Procedimentos para registro e } \\
\text { divulgação de dados sobre a } \\
\text { violência contra LGBTI no DF. }\end{array}$ & 2017 \\
\hline
\end{tabular}

Fonte: Autor 


\section{Políticas Públicas de Educação}

Associada a discussão das Políticas Públicas na área de segurança, a área da educação e a construção de políticas públicas nessa área começou a ganhar relevância e ser tomada como estratégica ao ser pensada como caminho que permitiria a desconstrução e a luta contra as discriminações e LGBTfobias, ao valorizar a convivência com as diferenças a partir da formação de valores pessoais. Desse modo, ainda em 1994, com a publicação das "Diretrizes para uma Política Educacional em Sexualidade" pelo Ministério da Educação (MEC) e o Ministério da Saúde, que apesar de baseado em uma perspectiva de regulação da prática sexual e orientada por critérios do "sexo seguro", representou na prática em uma primeira inclusão efetiva do tema das sexualidades nos conteúdos e atividades curriculares da educação brasileira.

No entanto, somente uma década depois, no âmbito do MEC, com a criação da Secretaria de Educação Continuada, Alfabetização e Diversidade (SECAD), ocorre uma valorização de temas antes marginalizados na pauta governamental como a discriminação racial e sexual passam a ser debatidos e negociados com a sociedade civil com o fim de construção de políticas públicas e editais que se centrassem na formação de educadores(as) atentos(as) e com instrumentos adequados para lidarem com as diferenças de orientação sexual e identidade de gênero, processo que também foi fortemente influenciado pelo Programa Brasil Sem Homofobia lançado em 2004.

Hoje, no que tange a Políticas Públicas de Educação para LGBTs no âmbito nacional, podemos rapidamente pensar em dois conjuntos de iniciativas: 1- a capacitação professores e profissionais da educação, seja por meio de cursos, seminários, debates, projetos ou mesmo a compra, distribuição, reformulação elaboração de livros didáticos, manuais escolares e programas educativos sobre a temática LGBT; 2- Portarias e Resoluções, Pareceres e Diretrizes que tomam como foco o direito ao uso do nome social por travestis e transexuais nas escolas. No âmbito da região Centro-Oeste, temos um quadro muito parecido com o nacional, com as ações centradas nas aprovações dos Planos Estaduais, distritais e municipais de Educação, que asseguram o desenvolvimento de projetos curriculares com os temas de gênero e sexualidade; luta contra o preconceito e a discriminação relacionados a identidade de gênero e orientação sexual; bem como a formação continuada de profissionais de educação nos temas de gênero 
e sexualidade. Tais ações, no entanto, vem sofrendo grande refluxo nos últimos anos com a retirada dos temas e termos "gênero" e "orientação sexual" dos planos estaduais, distritais e municipais. Um exemplo disso se deu em Cuiabá em 2015, por pressão de entidades e lideranças do conservadorismo cristão (evangélicos e católicos), que realizaram uma manifestação contra a "ideologia de gênero" no dia da votação do Plano Municipal de Educação (PME) de Cuiabá na Câmara de Vereadores, aclamando discursos de intolerância e ódio contra as populações LGBT. Apesar do cenário de ascensão do conservadorismo político no cenário estadual, o Plano Estadual de Educação (PEE), aprovado em 2014, não sofreu ataques e manteve os diversos pontos que fazem referência à promoção do debate sobre diversidade sexual e de gênero nas escolas. 


\section{Considerações Finais}

O cenário das políticas públicas para LGBTs nos estados do CentroOeste, em especial em Mato Grosso, local onde venho desenvolvendo minhas investigações, não é muito diferente do nacional, com alguns avanços das políticas sexuais e da cidadania LGBT nos últimos quinze anos - desde a publicação do PNDH II, em 2002, e do Brasil Sem Homofobia, em 2004, aos dias atuais - encontrando seu momento de estagnação ou marcação do fim de um ciclo. Vivemos hoje aqui neste estado um momento de reação conservadora contra tais avanços e implementações de políticas públicas, em uma conjuntura bastante desfavorável para a noção de direitos humanos de forma geral.

Temos de ressaltar, no entanto, que apesar de ocorrer uma intensificação do crescimento do fundamentalismo cristão que promove políticas sexuais conservadoras e a deslegitimação de direitos e políticas públicas destinadas à população LGBT, há ainda um grande espaço de debates, diálogos e alianças sendo desenvolvidos e estabelecidos entre movimentos sociais e diversos agentes públicos buscando a efetivação e a garantia de direitos e da cidadania para a população LGBT.

O cenário que se desenha no Brasil hoje é carregado de embates políticos tensos e conflituosos com grupos disputando modelos distintos de políticas estatais e com os movimentos sociais se constituindo ainda como uma peça fundamental para a conquista, manutenção e ampliação de direitos e cidadania no Brasil, sendo o fortalecimento e a rearticulação do movimento LGBT uma parte essencial desse caminho. Efetivamente, ainda não vivemos a possibilidade do fim da cidadania LGBT no Brasil, mas os retrocessos e barreiras levantadas nos últimos anos não devem ser minimizados servindo de alerta para o crescimento do poder de grupos que desejam o fim de um Estado promotor de direitos humanos e sociais. 


\section{REFERÊNCIAS}

BRASIL. Ministério da Justiça. Programa Nacional de Direitos Humanos - PNDH 2. Brasília, 2002.

BRASIL. Plano Nacional de Promoção da Cidadania e Direitos Humanos de LGBT. Brasília, 2009.

BRASIL. Ministério da Saúde. Brasil sem Homofobia. Programa de Combate à Violência e à Discriminação contra GLTB e Promoção da Cidadania Homossexual. Brasília: Ministério da Saúde, 2004.

BRASIL. Ministério da Saúde. Política Nacional de Atenção Integral de Lésbicas, Gays, Bissexuais, Travestis e Transexuais. Brasília: Ministério da Saúde, 2010.

BRASIL. Secretaria Especial dos Direitos Humanos. Plano Nacional de Promoção da Cidadania e Direitos Humanos de Lésbicas, Gays, Bissexuais, Travestis e Transexuais. Brasília: Secretaria Especial dos Direitos Humanos, 2010.

BRASIL. Presidência da República. Secretaria Especial de Direitos Humanos. 2013. Relatório sobre Violência Homofóbica no Brasil: ano de 2012. Brasília: SEDH/PR.

CARRARA, Sérgio; VIANA, Adriana R. B. 2008. Políticas Sexuales y Derechos Sexuales en Brazil: estudio de caso. In: PARKER, Richard.; PETCHESKY, Rosalind; SEMBER, Robert. Políticas sobre Sexualidad: Reportes desde líneas del frente. Sexuality Policy Watch. Disponível em: http://sxpolitics.org/es/wp-content/uploads/sites/3/2016/03/sexpolitics-en.pdf [Acessado em 02.07.17].

FROEMMING, C. N.; IRINEU, B. A.; NAVAS, K. Gênero e Sexualidade na Pauta das Políticas Públicas no Brasil. Revista de Políticas Públicas, Número Especial, p. 161-172, 2010.

LOPES, M. e ARAGUSUKU, H. Preconceito, Discriminação e Cidadania LGBT: Políticas Públicas em Mato Grosso e no Brasil. ACENO, Vol. 3, N. 5, Jan. a Jul. de 2016, p. 242-258.

LOPES, M. e SILVA, J. "De chapa e cruz", "paus rodados" aqui "tem de um tudo": Da movimentação de homossexuais ao movimento LGBT de Cuiabá e do Mato Grosso. ACENO, Vol. 2, N. 4, p. 41-54. Ago. a Dez. de 2015.

LOPES, Moisés. Algumas observações sobre as homossexualidades em "Contextos Interioranos": Lançando questões de "Fora dos Centros". Amazônica: Revista de Antropologia, v. 8, p. 24-37, 2017.

LOPES, Moisés; ARAGUSUKU, H. A. Políticas públicas e cidadania LGBT em Mato Grosso: Uma década de avanços e retrocessos (2007-2017). Sexualidad, Salud y Sociedad. Revista Latinoamericana. Rio de Janeiro, p. 147-171, 2018.

LOPES, Moisés. A construção de Políticas Públicas para pessoas LGBTI+ no Centro-Oeste do Brasil: Uma visão exploratória. In: Artur Zimerman. (Org.). Desigualdade Regional e as Políticas Públicas: Políticas LGBTI+. 1ed.Santo André: Universidade Federal do ABC, 2019, v. 14, p. 38-53. 
LOPES, Moisés. Políticas Públicas de Saúde para Travestis e Transexuais em Mato Grosso: Problematizações preliminares. In: Sonia Lourenço; Marcos Aurélio da Silva; Moisés Lopes. (Org.). Dissidências, alteridades, poder e políticas: antropologias no plural. $1 \mathrm{ed}$. Florianópolis: Editora da UFSC, 2020, v. 1, p. 83-98.

LOPES, Moisés; SILVA, Marcos Aurélio. Festa, política e o corpo na rua: Uma antropologia visual da Parada da Diversidade de Cuiabá nos 50 anos de Stonewall. Revista Brasileira de Estudos da Homocultura - REBEH, v. 02, p. 180-197, 2019.

MELLO, L.; BRITO, W.; MAROJA, D. Políticas Públicas para a população LGBT no Brasil. Notas sobre alcances e possibilidades. Cadernos Pagu, (39), julho-dezembro de 2012, p. 403-429.

MELLO, L.; MAROJA, D.; BRITO, W. Políticas Públicas para população LGBT no Brasil: um mapeamento crítico preliminar. Relatório de Pesquisa. Goiânia, UFG, Faculdade de Ciências Sociais, Ser-Tão, Núcleo de Estudos e Pesquisa em Gênero e Sexualidade, 2010.

MELLO, L.; PERILO, M.; BRAZ, C.A.; PEDROSA, C. Políticas de saúde para lésbicas, gaysm bissexuais, travestis e transexuais no Brasil. Em busca de universalidade, integralidade e equidade. Sexualidad, Salud y Sociedad. Revista Latinoamericana. n. 9, p. 7-28, dec. 2011.

MELLO, L.; AVELAR, R.B. Por onde andam as Políticas Públicas para a população LGBT no Brasil. Revista Sociedade e Estado, Vol. 27, n² 2, maio/agosto 2012, p. 289-312. 


\title{
OS ASPECTOS PSICOSSOCIAIS DO ATENDIMENTO DE MULHERES, LGBT+ E CRIANÇAS NA DEFENSORIA PÚBLICA - NÚCLEO CRIMINAL DO MUNICÍPIO DE RONDONÓPOLIS
}

\author{
Márcio Alessandro Neman do Nascimento \\ Amanda Bravo Pereira Almeida \\ Lissa Carvalho de Souza \\ Maria Carolina Kovaleski Ferreira
}

A Defensoria Pública é uma instituição presente em todos os estados do país e que tem como função a defesa gratuita da garantia de direitos, sejam eles individuais ou coletivos, às pessoas que não podem arcar com os custos de uma ação jurídica (BRASIL, 2009). Entre as ações desenvolvidas por essa instituição estão a orientação jurídica, a conciliação extrajudicial (mediação, conciliação e arbitragem) e a defesa dos grupos em situação de vulnerabilidade social (crianças, adolescentes, mulheres vítimas de violência de gênero, idosos e pessoas com necessidades especiais e em situação de doença crônica). A Lei Complementar n 132 de 2009, que organiza as ações da Defensoria Pública, também prevê que esse órgão preste "atendimento interdisciplinar, por meio de órgãos ou de servidores de suas Carreiras de apoio para o exercício de suas atribuições" (BRASIL, 2009). Dessa forma, entende-se que o trabalho exercido na Defensoria pode abranger outras áreas de atuação que não somente a do Direito, visto que os casos atendidos possuem especificidades que podem ser positivamente trabalhadas por outras áreas, como a Psicologia e o Serviço Social, uma vez que os profissionais desses campos possuem arcabouço teórico-metodológico para atender às demandas da população assistida.

Diversos núcleos da Defensoria Pública apresentam em seu quadro de funcionários profissionais da Psicologia que atuam em diferentes funções. Em alguns estados, como São Paulo, que possui legislação que especifica obrigatoriedade do atendimento psicológico nesse órgão, a presença desses profissionais é proeminente. Os profissionais da Psicologia que atuam 
nos núcleos das Defensorias Públicas podem cumprir diversas funções, como o auxílio nos serviços de mediação e conciliação ou no atendimento especializado às pessoas que procuram os serviços da Defensoria.

O Estado de Mato Grosso não possui nenhuma lei que inclua outros profissionais, além daqueles/as do Direito, nos serviços jurídicos. Apesar disso, alguns esforços são feitos para incluir os serviços da Psicologia no quadro de atividades dos núcleos estaduais, que se fazem por meio de parcerias com as Universidades Federais. Em Rondonópolis, uma parceria entre os núcleos cível e criminal da Defensoria e o Laboratório Esquizoanalista de Produção de Subjetividades e $(\mathrm{m})$ Interseccionalidades (LEPSI), alocado no curso de Psicologia da Universidade Federal de Rondonópolis (UFR-MT), foi firmada em 2017. As/os estagiárias/os e extensionistas ligadas/os a esse núcleo realizam atendimentos psicossociais com pessoas que possuem algum processo judicial em trâmite e apresentam sofrimento psicológico.

Ao pensarmos a inclusão do serviço de Psicologia na Defensoria Pública, que é destinada ao atendimento da população sem condições financeiras de arcar com os custos de ações jurídicas, compreendemos que, como psicólogas/os, devemos desempenhar práticas pautadas em um entrelaçamento entre a Psicologia e a Política de Direitos. Isso implica, além da garantia e defesa de direitos dos sujeitos atendidos, a reflexão sobre os impactos de nossa atuação, visto que qualquer intervenção é política, e a/o profissional deve estar ciente da inexistência de neutralidade nessas intervenções.

Dessa forma, para exercer uma prática em consonância com os direitos humanos ou buscar reivindicar esses direitos, de maneira a compreender quem são as pessoas que chegam até essa instituição pública, apoiamos o serviço oferecido por nós, estagiárias/os de Psicologia, na perspectiva interacional entre teoria, prática e supervisão e em um modelo de clínica ampliada e psicoterapia breve, pautado em um posicionamento teóricometodológico esquizoanalista e de autoras/es pós-estruturalistas.

A clínica ampliada pode ser definida como um modelo no qual entendemos que o sofrimento psíquico é proveniente de macropolíticas, não sendo possível separar as relações sociais e as suas desigualdades do sofrimento individual. Sendo assim, buscamos compreender quais são os atravessamentos que perpassam a existência e a subjetivação de cada 
pessoa. Esse modelo busca promover a autonomia dos sujeitos e a garantia de que seus direitos fundamentais sejam respeitados (RIBEIRO; GOTO, 2012).

Além da clínica ampliada, nossa atuação também é desempenhada em consonância com os preceitos do atendimento psicossocial. Na perspectiva esquizoanalista, esse atendimento se caracteriza por uma escuta breve e qualificada que tem por objetivo construir um mapa cartográfico dos atravessamentos presentes no processo de individuação e subjetivação de cada pessoa. Nesse mapa, que advém do discurso da/o atendida/o, são analisados o máximo possível de marcadores sociais, como a classe socioeconômica, raça/etnia/cor da pele, orientação sexual, gênero, entre outros, a fim de compreender melhor as demandas apresentadas. Em meio a esse processo de (re)construções, o acompanhamento psicossocial esquizoanalítico funciona não só como um espaço político de fala, mas também como um local protegido que prima pelo sigilo e fortalecimento do vínculo estagiária/o - extensionista - atendida/o.

As principais demandas que atendemos no serviço de Psicologia da Defensoria se referem a casos de mulheres e crianças vítimas de violência intrafamiliar, sexual e de gênero. Os casos atendidos são comumente encaminhados pela própria equipe jurídica das Defensorias Cível e Criminal e pela Delegacia Especializada de Defesa da Mulher. Também somos responsáveis por atender a população LGBT+, com ênfase na atenção para transexuais e travestis, que não precisam, necessariamente, estar utilizando os serviços judiciais da Defensoria. A escolha por ofertar atendimento a essas pessoas se fundamenta no reconhecimento das situações de vulnerabilidades sociais às quais estão sujeitas.

Assim, a Psicologia (especificamente a Psicologia Social) tem se implicado em refletir sobre a dinâmica social, como as pessoas se relacionam e como afetam o meio em que vivem, de modo a propor reflexões críticas com relação a forma com que a cultura, por vezes opressora, está estruturada. Ao propor que as pessoas analisem questões estruturais que há tempos causam sofrimento, a Psicologia busca romper com padrões sociais de estereótipos, normatividades, binarismos, preconceitos e marginalizações, auxiliando as pessoas a se perceberem enquanto corpo singular, único e possuidor de direitos (ALMEIDA, 2018).

A partir das contextualizações acima, nos debruçaremos agora acerca do objetivo deste trabalho, que consiste em apontar algumas das queixas 
e demandas presentes nos relatos de mulheres cisgênero, transexuais, travestis e crianças, todas vítimas de violência, que foram por nós atendidas. Para tal, buscamos analisar as similaridades e divergências presentes nas vivências dessas mulheres e aspectos que se relacionam com os papéis sociais de cada uma delas, sendo esses definidos pelos atravessamentos de raça/etnia/cor da pele, gênero, orientação sexual, saúde mental e física e faixa etária.

\section{Atendimento de mulheres vítimas de violência(s): Relações de poder, violência de gênero e a clínica psicológica ampliada}

De acordo com Heleieth Saffioti (2001), a violência de gênero pode ser definida como um termo amplo que inclui atos que violam direitos de mulheres (cis e trans), crianças ou idosos, entre outras categorias de gênero. Desde muito cedo, a sociedade patriarcal insiste em postular o lugar da mulher como sendo a cozinha, os cuidados domésticos em geral e o cuidado com os filhos e com seu companheiro. Quando se imagina o universo de possibilidades atribuído aos homens versus a quantidade tão pequena (porém cheia de sobrecarga psíquica e física) de atividades dirigidas às mulheres e frequentemente consideradas tarefas femininas, é possível perceber o quanto as mulheres foram historicamente diminuídas em suas capacidades.

O poder exercido pelo homem sobre a mulher é legitimado culturalmente. Ao considerar que o patriarcado é responsável por determinar condutas de diversas categorias sociais, é possível observar o quanto essa relação homem-mulher-cultura está emaranhada em comportamentos coercitivos. $O$ fato de mulheres serem violentadas por homens traz diversos atravessamentos que devem ser levados em consideração, mas, aqui, nos debruçaremos sobre um dos aspectos mais relevantes na questão das violações de mulheres: o poder que a cultura machista mantém e o quanto a força física, termo frequentemente atribuído a homens cisgênero, possui um devir que abre caminhos (no imaginário masculino cis) para a violência física e dominação psicológica (SAFFIOTI, 2001).

De acordo com Lúcia Fucks (2002), por alguns séculos o Brasil se apresentou dominado predominantemente por homens cis, ao passo que a eles cabia administrar seus bens de valia e isso incluía as companheiras 
conjugais, o que, por si só, já caracterizava um cenário de desigualdade de gênero e violência.

Ao observar todo esse contexto em que o homem dita as regras e obriga a mulher a cumpri-las, é possível fazer uma análise do quanto esse rompimento (incompleto) de hierarquias de gênero, advindo da emancipação das mulheres, provocaria confrontos para além de discussões verbais, envolvendo violências físicas, psicológicas e até feminicídio. Em suma, o Conselho Federal de Psicologia (CFP) (2012, p. 32), nas "Referências técnicas para atuação de Psicólogas(os) em Programas de Atenção à Mulher em situação de Violência", argumenta que a violência contra a mulher seria uma das consequências do processo de socialização machista, misógino e pautado no patriarcado e viriarcado, que ocorre em espaços privados/ públicos em ocasiões em que mulheres ousam contrariar o padrão comportamental subalterno que foi instituído como único modo de existir.

Apesar de ser frequentemente abordado por campanhas como um fator isolado e de não serem levados em consideração os diversos motivos que contribuem com a ocorrência de violações de gênero, Patrícia Grossi (1996) externa que esse tipo de violência já foi inclusive considerado um caso de saúde pública pela Organização Mundial da Saúde (OMS). Isso porque mulheres que sofrem com agressões tendem a usar com mais frequência os serviços públicos, ao passo que vivenciam um ciclo difícil de inseguranças e traumas ocasionados pelo contexto hostil e desagradável.

Falar da violência sofrida pela mulher é também resgatar seus desejos e afetos. Pelo fato de considerarmos o aspecto biopsicossocial da mulher, ou seja, de nos interessarmos pela integralidade do sujeito, bem como pela potencialização de sua vida, as práticas que desenvolvemos na clínica ampliada da Defensoria Pública de Rondonópolis ocorreram de modo a promover cuidados que fossem para além das reflexões acerca das violências. No entanto, ainda que se estimule o restabelecimento dos afetos e desejos das vítimas, é notável que são muitas as dificuldades encontradas para tal. Nesse sentido, as principais consequências sofridas/apresentadas pelas mulheres que foram/são agredidas incluem irritabilidade, humor instável, medo, ansiedade excessiva, insegurança, insônia ou sono em excesso e quadros de depressão (KASHANI; ALLAN, 1998).

Ainda conforme o CFP (2012, p. 46), a violência de gênero é um fenômeno complexo e multifacetado que exige compreensão e intervenções 
multidisciplinares, bem como ações de conscientização em defesa das mulheres, haja vista que boa parte das mulheres que chegam a denunciar seus agressores possuem certo nível de instrução. Assim, na Defensoria Pública de Rondonópolis os trabalhos são realizados em conjunto com outras áreas, como o Direito. Embora sejam encontradas algumas dificuldades com relação à precariedade dos serviços públicos, dada a grande demanda de casos encaminhados, a clínica ampliada na Defensoria tem cumprido boa parte dos critérios indicados pelo CFP (2012, p. 48) acerca da atuação do(a) psicólogo(a), bem como: "escuta qualificada e acolhimento, [...] promoção da autoestima, superação da situação de violência e promoção de autonomia, superação da vitimização e fortalecimento das mulheres".

Nesse sentido, ter um lugar de escuta e proteção se torna indispensável para as mulheres no processo de denúncia. Os atendimentos psicossociais têm grande importância, ao passo que buscam promover reflexões a fim de que mulheres que sofreram violências compreendam que não têm culpa, que são vítimas e que podem romper com esses contextos de graves violações.

\section{0 atendimento às/aos transexuais e as vulnerabilidades das identidades abjetas}

Além desse público de mulheres cis, outro grupo que também teve acesso aos atendimentos psicossociais oferecidos na Defensoria foi composto por pessoas LGBT+, mais especificamente por pessoas transexuais e travestis. Apesar dos atendimentos serem destinados tanto para homens como para mulheres trans, foram atendidas apenas mulheres. Para compreender a realidade dessas pessoas, é importante salientar alguns fatos e dados.

A sociedade brasileira sustenta um sistema de classificação dos corpos em aceitáveis ou não, sendo o grupo hegemônico constituído por corpos que são perpassados pela branquitude, riqueza, heterossexualidade e cisgeneridade. O primeiro elemento, branquitude, é fundamentado por Lia Vaine (2014) como a posição mais elevada da hierarquia racial, possibilitando um poder de classificar os outros como não brancos. Nesse sentido, ser branco torna o sujeito como proprietário de privilégios raciais que são simbólicos e materiais. Enquanto isso, para os sujeitos de pele preta no Brasil, a cadeia e as favelas se tornam uma realidade, sendo esses sujeitos violentados e subalternizados socialmente (GOMES; NETO; CAFOLA, 2019). 
No Mapa do encarceramento: os jovens do Brasil (SINHORETTO, 2015) e de acordo com Ronaldo Barros, antigo Secretário de Políticas de Ações Afirmativas da Secretaria de Políticas de Promoção de Igualdade Racial, verificamos que no ano de 2005 havia 92.052 pessoas negras presas e 62.569 brancas, ou seja, 58,4\% dessa população era negra. Em 2012, o número era de 292.242 pessoas negras presas e 175.536 brancas, sendo então 60,8\% da população prisional negra. Com isso, constatamos que, à medida que cresce a população prisional no Brasil, cresce também o número de pessoas negras encarceradas (GOMES; NETO; CAFOLA, 2019).

Outro fator que influencia a condição de margem social para além da cor de pele é a condição social, a classe, ser pobre. A classe social dos sujeitos é fonte de heranças simbólicas, de valores tanto morais como existenciais, que são passadas pelas gerações por laços de afeto, não se restringindo ao acesso a determinada renda.

Referente a sexualidades não hegemônicas, que também influenciam na condição de margem social, é importante salientar que essas pessoas dissidentes foram objeto de construção de uma taxonomia médico-legal no Brasil desde os fins do século XIX. Nos anos 60, ao serem consolidados os movimentos sociais, surge no final dessa década o movimento "homossexual" (como era denominado na época), surgimento que esbarra na vinculação da AIDS como uma doença dos homossexuais. O "homossexualismo" só foi retirado do Código Internacional de Doenças (CID) na segunda metade de 1980, com o CID-10.

Em se tratando da transexualidade, apesar de a OMS não a classificar como um tipo de transtorno de identidade de gênero desde 2018, com o lançamento da CID-11, no Manual Diagnóstico e Estatístico de Transtornos Mentais 5 (DSM-5), o homem e a mulher trans são diagnosticados como portadores da "disforia de gênero", por se identificarem com a masculinidade e a feminilidade que diverge da esperada pelo meio social em função do seu sexo biológico, disforia essa que leva os sujeitos a demandarem a mudança de sexo por meio de um procedimento cirúrgico (GOMES; NETO; CAFOLA, 2019; POPADIUK; OLIVEIRA; SIGNORELLI, 2017; UNAIDS, 2018).

A demora para que a transexualidade passasse do capítulo de doenças mentais para o capítulo a respeito de saúde sexual no CID-11, assim como a permanência do diagnóstico no DSM-5, demonstra como as pessoas transgênero, incluindo travestis e transexuais, problematizam e estremecem 
a hegemonia do sexo biológico como determinante da identidade de gênero e por essa razão, além desse grupo ser diagnosticado e marginalizado, também é encarado com estranhamento. Dessa forma, entre as pessoas $\mathrm{LGBT+}$, socialmente as pessoas trans se constituem como as que mais sofrem preconceitos, discriminações e violências (POPADIUK; OLIVEIRA; SIGNORELLI, 2017; UNAIDS, 2018).

O tratamento desses sujeitos como abjetos é evidenciado nos dados do Relatório sobre Violência Homofóbica no Brasil (2012). Esse relatório apresenta que as pessoas trans continuam sendo as maiores vítimas de violência LGBT+, sendo essas violências de maior gravidade, com homicídios e lesões corporais. Vale ressaltar que esses dados não são tão fidedignos quando pensamos que muitas vítimas não denunciam. A Organização Não Governamental Transgender Europe revela que o Brasil é o país com mais homicídios de pessoas trans no mundo, sendo que entre janeiro/2008 e abril/2013, ocorreram 486 mortes, valor quatro vezes maior que o registrado no México, que é o segundo colocado (POPADIUK; OLIVEIRA; SIGNORELLI, 2017).

Quando nos restringimos ao estado do Mato Grosso, essa realidade de violência, discriminação e vulnerabilidade contra pessoas desviantes da normativa cisgênero se mantém. Sendo o estado em que o poder econômico do agronegócio influencia diretamente nos processos políticos legais, executando coerção sobre partidos, parlamentares, governantes, gestores e constituição da sociedade civil, com a presença de uma hegemonia conservadora que se articula com as oligarquias e grupos tradicionais ligados às elites econômicas do agronegócio, não surpreendentemente é também o estado que ficou em segundo lugar nos índices de denúncias referentes à violência contra LGBT+ por número total de habitantes, segundo o "Relatório sobre Violência Homofóbica no Brasil", de 2012 . Acrescido a isso, no relatório de 2013, a cidade de Cuiabá foi classificada como a capital mais homofóbica do país (ARAGUSUKU; LOPES, 2018).

Nesse sentido, ao reconhecermos as complexidades dos determinantes sociais relacionados ao processo saúde/doença de pessoas trans, assim como ao considerarmos os altos índices de violência, discriminação, homicídios e suicídios, tanto nacionais como estaduais, referentes a esse grupo, verificamos a importância de políticas públicas que possibilitem a diminuição dos processos de estigmatização e que contribuam com a saúde 
desse grupo. Foi considerando a importância da existência de dispositivos que auxiliem nesse processo de saúde mental que os atendimentos a pessoas transexuais foram instaurados na Defensoria Pública (POPADIUK; OLIVEIRA; SIGNORELLI, 2017).

Ressaltamos que os atendimentos psicossociais ofertados às/aos transexuais e travestis encontram-se em consonância com as resoluções $n^{\circ} 001 / 99$ e $n^{\circ} 001 / 18$, do CFP, que estabelecem as normas de atuação das/ os psicólogas/os em relação à orientação sexual e a identidade de gênero das/os atendidas/os, salientando o compromisso das/os profissionais da Psicologia contra os comportamentos LGBTfóbicos, exigindo a realização de práticas que reconheçam a legitimidade da sexualidade e da identidade de gênero dessas pessoas.

As pessoas trans que buscam atendimento na Defensoria são atravessadas por esses fatores de vulnerabilidade e o atendimento psicossocial que realizamos com esses sujeitos possibilitam a visualização dessas desigualdades estruturais presentes nos relatos das/os atendidas/ os. Nos relatos e queixas de uma pessoa atendida, verificamos vivências de situação de rua, internações psiquiátricas, encarceramento, racismo, inúmeros relacionamentos abusivos, preconceito familiar, abuso de drogas, assim como outras violências vivenciadas cotidianamente. Todos esses aspectos e experiências individuais, que são reflexos de macropolíticas, constituem as subjetividades dessas pessoas e se inter-relacionam com a condição de passividade e baixa autoestima em que se encontravam as/os pacientes quando buscaram atendimento.

Apesar de identificarmos demandas que poderiam ser trabalhadas por profissionais de Psicologia, como a passividade, a baixa autoestima, assim como presença de sintomas característicos de transtornos mentais, inicialmente primamos por realizar um trabalho de base. Diante da falta de acesso à alimentação, moradia e higiene pessoal, observada na vida dessas pessoas e considerando que a garantia dessas condições é direito básico de todo ser humano e que a falta delas reflete na saúde mental das pessoas, de início, as intervenções realizadas visaram garantir às/aos assistidas/os esses direitos básicos de sobrevivência.

Para isso, dispositivos da rede do serviço público foram contatados para possibilitar o acesso a esses direitos. Algumas limitações foram encontradas em relação à moradia, pois o único local que abrigava pessoas em condição 
de rua não estava mais em funcionamento e os outros locais que ofereciam moradia para esse público eram coordenados por instituições religiosas, que exigiam que os moradores se comportassem de acordo com os padrões cis-heteronormativos.

\section{Abuso sexual infantojuvenil: uma questão de dominação por gênero e idade}

Além das demandas já mencionadas anteriormente, recebemos na Defensoria Pública encaminhamentos advindos de diversos dispositivos municipais, referentes aos atendimentos de crianças e adolescentes vítimas de abuso sexual.

O abuso sexual é um tipo de violência caracterizado por ato sexual, homo ou heterossexual, que tem como objetivo a satisfação sexual por meio da estimulação da vítima. Essa prática violenta ocorre em todas as idades, no entanto, em alguns casos uma relação de poder entre vítima e agressor é mais evidente, como acontece em episódios de abuso sexual envolvendo crianças e adolescentes (ROSSATO et al, 2018). Dados do Sistema de Informação de Agravos de Notificação (SINAN) mostram que em 2013 foram notificados 80.418 casos de agressão a crianças e adolescentes, com idades entre 0-19 anos, vítimas de violência doméstica, sexual e outras violências. Desses casos, 28,4\% das crianças com idade de 0 a 9 anos e 23,9\% das/os adolescentes entre 10 e 19 anos foram vítimas de violência sexual. Nesses dois grupos, as meninas são a maior parte das vítimas (BRASIL, 2017).

Os dados de 2013 corroboram com pesquisas que investigaram as principais características das vítimas de violência sexual infantojuvenil e enfatizam tipos de relação de poder que estão envolvidas nessa violência (MARTINS; JORGE, 2010; FONSECA et al., 2012; MARRA; COSTA, 2016; ROSSATO et al, 2018). É notável que existe uma relação de poder relacionada à idade e ao gênero da vítima. Dessa forma, é imprescindível discutir como tais aspectos são socialmente construídos e entendidos, pois essas relações perpetuam um tipo de violência que, ao mesmo tempo que é abominada, também é silenciada.

De acordo com Joan Scott (1995), gênero deve ser uma categoria de análise em todas as propostas que se dedicam a compreender um fenômeno social, pois esse aspecto, juntamente com as categorias de classe e raça, são símbolos que devem ser considerados para entender como foram 
construídas as dinâmicas sociais, já que tais conceitos estão presentes em todas as relações sociais e estão intimamente ligados ao poder e à dominação. Dessa forma, para entendermos o elevado índice de violência sexual contra meninas devemos primeiramente entender como a relação de gênero implica uma posição de assujeitamento. Martha Narvaz (2005, p. 18) afirma que "conviver com a violência imposta pela socialização desigual e sexista de gênero desde tenra idade faz com que as práticas abusivas sejam naturalizadas e banalizadas".

A relação de gênero envolve uma posição de dominante-dominado, no sentido de que existe uma relação de poder que é muitas vezes naturalizada. Homens são muitas vezes dispensados da responsabilidade por possuírem "necessidades biológicas" que estão intrinsecamente relacionadas ao seu sexo, da mesma forma que mulheres e meninas são responsabilizadas por não se comportarem de maneira "adequada". De acordo com Rosa Maria Godoy Serpa da Fonseca et al. (2012), atributos naturais, como o sexo biológico, são utilizados como justificativa social que perpetuam privilégios e desigualdades. No contexto que estamos discutindo, essa relação de privilégio e poder é ainda mais presente, já que as vítimas não possuem capacidade de compreender ou consentir as práticas realizadas.

Durante os atendimentos de crianças e adolescentes vítimas de violência sexual, é possível observar o quanto seus relatos são pistas de que a questão de gênero está ligada a esse tipo de violência. Em um dos atendimentos realizados, uma menina de 11 anos relatou que o agressor, um homem conhecido da família e que frequentemente visitava a casa da vítima, quando confrontado, afirmou que a menina o estava provocando. Tal relato expressa a sexualização e culpabilização da vítima.

A relação entre gênero e violência deve ser uma categoria de análise em casos de violência sexual. No entanto, dada a desigualdade geracional entre agressor e vítima, é necessário também discutir o papel que a relação entre idade e poder estabelece no contexto de violência sexual infantojuvenil. De acordo com o artigo $6^{\circ}$ da Constituição Federal, os pais desempenham função protetiva em relação à criança e à/ao adolescente e por isso é de sua responsabilidade promover o bem-estar e a garantia de direitos das/os filhas/ os. Porém, segundo Eva Faleiros e Josete Campos (2000), historicamente a criança não é vista como um sujeito de direitos. Essa percepção é fator que faz com que crianças sejam consideradas "patrimônio" de seus pais ou 
responsáveis, fator que facilita a legitimação de episódios de qualquer tipo de violência. De acordo com Maria Minayo (2001), a violência exercida de adultos para com crianças e adolescentes é “(...) uma negação do direito que crianças e adolescentes têm de serem tratados como sujeitos e pessoas em condições especiais de crescimento e desenvolvimento" (MINAYO, 2001).

Diante disso, é imprescindível considerar, no contexto de acompanhamento psicossocial que realizamos na Defensoria Pública e em todas as instituições em que as/os profissionais de Psicologia se fazem presente, os aspectos sociais que são historicamente construídos, levados em conta tanto na descrição dos relatos feitos pelas vítimas, quanto nas propostas de intervenção que são realizadas. Durante os atendimentos realizados com crianças e adolescentes vítimas de abuso sexual, buscamos verificar os atravessamentos sociais sobre gênero, relações familiares, relação com o corpo, entre outros, que nos permitissem entender sob que ótica aquelas pessoas encaravam e viviam as violências.

\section{O fundamentalismo dogmático, a construção das violências e seus reflexos nas políticas públicas destinadas às mulheres e crianças em sofrimento psíquico intenso}

A exposição de fragmentos de relatos e das construções sociais que perpetuam violências, como nos exemplos dos casos apresentados neste artigo, evidenciam a importância de políticas públicas voltadas para o atendimento das necessidades específicas dos grupos que são caracterizados como vítimas de violências, como é o caso de mulheres, crianças e da comunidade LGBT+.

Entre os muitos elos que podem constituir uma política pública, é necessário considerar o papel fundamental que a escola pode exercer. Por ser um lugar de formação e de intenso contato com a realidade das/ os estudantes, a equipe escolar é muitas vezes a primeira esfera a perceber e notificar, como previsto em lei, casos de sofrimento no indivíduo ou na família. Além disso, as equipes escolares, ao inserir em seus currículos a educação sexual, passam a contribuir para que as crianças reconheçam e relatem casos de abuso sexual dentro de seu contexto familiar.

Infelizmente, o contexto político atual, baseado em "valores morais", extinguiu essa e outras políticas, como a "Educação em Direitos" e "Gênero e Diversidade Sexual", que visavam uma formação humana e a prevenção de 
casos de violência. A descontinuidade de projetos como esses pode ser um fator que silencie, cada vez mais, casos de violação de direitos (DE MOURA; DA COSTA SALLES, 2018).

Além disso, da mesma forma que a educação sofre com a ascensão desse discurso autoritário e excludente baseado em valores morais e religiosos fundamentalistas, no que concerne aos atendimentos às pessoas trans, verificamos que as políticas públicas que atendem essas pessoas são limitadas e falhas, uma vez que esses discursos dogmáticos e radicais baseados em preceitos binários e heterocisnormativos também estão presentes nas instituições públicas e refletem nas práticas desenvolvidas.

Sendo assim, pessoas que não se encaixam nesse modelo binário de gênero e sexualidade não são de fato integralmente assistidas pelo Estado, quando não são excluídas completamente dos planos e das ações. Ademais, observamos também que, como o Estado não consegue suprir a necessidade de uma população numerosa que se encontra em situação de vulnerabilidade, as instituições religiosas atuam cobrindo essas brechas, mas, em troca, exigem a padronização das pessoas que utilizam os serviços oferecidos.

No que concerne mais especificamente ao atendimento psicossocial que realizamos com as pessoas trans na Defensoria, em algumas situações encontramos dificuldades referentes à adesão ao atendimento em setting terapêutico, o que nos fez repensar a prática da/o profissional de Psicologia restrita a esse ambiente. Como forma de adequação ao conforto das/os atendidas/os, algumas sessões foram realizadas na calçada da Defensoria Pública, prática que reafirma o alcance da Psicologia para além da sala de atendimento.

Acerca dos atendimentos de mulheres cis, percebemos a importância desse espaço de escuta ética e sigilosa no acolhimento dessas pessoas, sobretudo quando o atual contexto político parece cada vez mais incitar práticas machistas e violentas. Atender mulheres vítimas de violência de gênero aponta ainda para a relevância de uma análise sócio-histórica a fim de perceber questões estruturais que foram (re)construídas há séculos e que ainda perpassam os dias atuais. É importante que a/o profissional de Psicologia pratique uma escuta sensível e acolha o sofrimento dessas pessoas com um olhar atento a marcadores sociais e a elementos da macro e 
micropolítica que (re)produzem relacionamentos abusivos e outras relações interpessoais violentas e agressivas.

Por fim, percebemos nossas ações na Defensoria Pública de Rondonópolis como uma prática de resistência que nos possibilitou analisar e atuar em políticas em defesa das mulheres, das crianças e das pessoas LGBT+, em especial transexuais e travestis. As especificidades de cada caso atendido nos fizeram construir uma prática psicológica mais engajada e coerente com as questões sociais e mais compromissada com as singularidades e multiplicidades humanas. 


\section{Considerações finais}

As reflexões a respeito dos relatos das pessoas atendidas no trabalho realizado evidenciam que, apesar das singularidades que as perpassam, como faixa etária, orientação sexual, identidade de gênero, classe social, econômica, há aspectos culturais que conectam todos os discursos dessas mulheres, LGBT+ e crianças e as situações de violência que vivenciam: o patriarcado, a misoginia, o machismo, a LGBTfobia e os seus efeitos. Judith Butler (2018) afirma que mesmo que o gênero, como paradigma, possa não abarcar todas as formas de existência, ele nos oferece um ponto de partida para pensar a respeito de poder, atuação e resistência. Nesse sentido, ao reconhecermos a existência de normas sexuais e de gênero que determinam os sujeitos "legíveis", compreendemos quem são os sujeitos "ilegíveis" e silenciados e como estes vivenciam a violência de gênero por não se enquadrarem na normativa homem-branco-cis-hetero-cristão-classe média.

A população atendida na Defensoria Pública sofre com as coerções e a posse que os homens exercem sobre seus corpos. Essas ações coercitivas deixam marcas, tanto físicas como psíquicas, que são naturalizadas pelo discurso de culpabilização da vítima. O acolhimento dos sofrimentos vivenciados por essas pessoas e a conscientização a respeito dessas relações de poder que se correlacionam com a situação de violência que vivenciam se constituem como intervenções importantes para a potencialização de suas vidas, auxiliando-as no planejamento de trajetórias que as fortaleçam.

Nesse sentido, para a realização dessas intervenções, nossa atuação buscou ir além das demandas judiciais das/os atendidas/os, visualizando essas pessoas como sujeitos sócio-histórico-políticos e culturais possuidores de direitos e imersos em um meio social que legitima alguns corpos e silencia outros. Consideramos também que os atendimentos psicossociais corroboram para medidas jurídicas mais efetivas, principalmente porque, se necessário, procuramos nos vincular a outros dispositivos da rede pública, para que as pessoas atendidas façam uso de seus direitos e se tornem protagonistas na construção de uma vida distante de violências. 


\section{REFERÊNCIAS}

ALMEIDA, Flávio Aparecido de. A psicologia social e o papel do psicólogo na sociedade contemporânea. Psicologia.pt. Jul, 2018. ISSN 1646-6977. Disponível em: < https://www. psicologia.pt/artigos/ver artigo.php?a-psicologia-social-e-o-papel-do-psicologo-nasociedade-contemporanea\&codigo=A1222\&area=d9>. Acesso em: 08 maio 2020.

ARAGUSUKU, Henrique Araujo; LOPES, Moisés Alessandro de Souza. Políticas públicas e cidadania LGBT em Mato Grosso: Uma década de avanços e retrocessos (2007-2017). Sex., Salud Soc. (Rio J.), Rio de Janeiro, n. 29, p. 147-171, Aug. 2018. Disponível em <http://www. scielo.br/scielo.php?script=sci_arttext\&pid=S1984-64872018000200147\&lng=en\&nrm=iso>. Acesso em: 3 mar. 2020.

BRASIL, Lei Complementar n 132, de 7 de outubro de 2009. Disponível em: http://www. planalto.gov.br/ccivil_03/leis/lcp/Lcp132.htm. Acesso em: 7 mar. 2020.

BRASIL. Ministério da Saúde. Secretaria de Vigilância em Saúde. Departamento de Vigilância de Doenças e Agravos Não Transmissíveis e Promoção da Saúde. Viva: Vigilância de Violências e Acidentes: 2013 e 2014 [recurso eletrônico] / Ministério da Saúde, Secretaria de Vigilância em Saúde, Departamento de Vigilância de Doenças e Agravos Não Transmissíveis e Promoção da Saúde. - Brasília: Ministério da Saúde, 2017. Disponível em: < $\underline{\text { http://bvsms. }}$ saude.gov.br/bvs/publicacoes/viva 2013 2014.pdf>.

BUTLER, Judith. Política de gênero e o direito de aparecer. In: Corpos em aliança e a política das ruas: notas para uma teoria performativa de assembleia. Rio de Janeiro: Civilização Brasileira, 2018.

CONSELHO FEDERAL DE PSICOLOGIA. Referências técnicas para atuação de psicólogas (os) em Programas de Atenção à Mulher em situação de Violência / Conselho Federal de Psicologia. Brasília: CFP, 2012.

DE MOURA, Fernanda Pereira; DA COSTA SALLES, Diogo. O Escola Sem Partido e o ódio aos professores que formam crianças (des) viadas. Revista Periódicus, v. 1, n. 9, p. 136-160, 2018.

FONSECA, Rosa Maria Godoy Serpa da et al. Reincidência da violência contra crianças no Município de Curitiba: um olhar de gênero. Acta paul. enferm., São Paulo, v. 25, n. 6, p. 895901, 2012. Disponível em: <http://www.scielo.br/scielo.php?script=sci_arttext\&pid=S010321002012000600011\&lng=en\&nrm=iso>. Acesso em: 7 mar. 2020.

GOMES, Aguinaldo Rodrigues; NETO, Miguel Rodrigues de Souza; CAFOLA, Diego Aparecido. De satã a diaba - O corpo negro homossexual no cinema brasileiro. In: SCUDDER, Priscila de Oliveira Xavier; GONZÁLEZ, José Marin; ÁVILA, Carlos Frederico Dominguez. Racismo Ambiental, Ecologia, Educação e Interculturalidade. Campo Grande: Life, v. 1, p. 61-83, 2019.

FALEIROS, Eva Silveira, CAMPOS, Josete de Oliveira. Violência Sexual - categoria chave na compreensão do abuso sexual contra crianças e adolescentes - Repensando os conceitos de violência,abuso e exploração sexual de crianças e adolescentes. Brasília, fevereiro de 2000. Disponível em: www.cecria.org.br. Acesso em: nov. 2005. 
GROSSI, Patrícia Krieger. Violência contra a mulher: implicações para os profissionais de saúde. In: LOPES, Meyer de Waldow. Gênero e Saúde. Porto Alegre: Artes Médicas, 1996, p. 133-149.

KASHANI, Javad H.; ALLAN, Wesley D. The impact of family violence on children and adolescents. Thousand Oaks, Ca: Sage, 1998.

MARRA, Marlene Magnabosco; COSTA, Liana Fortunato. Caracterização do abuso sexual em clientela do CREAS. Rev. Subj. Fortaleza, v.16, n.2, p.105-116, ago. 2016. Disponível em: <http://pepsic.bvsalud.org/scielo.php?script=sci_arttext\&pid=\$2359-07692016000200009\&ln g=pt\&nrm=iso>. Acesso em: 7 mar. 2020.

MARTINS, Christine Baccarat de Godoy; JORGE, Maria Helena Prado de Mello. Abuso sexual na infância e adolescência: perfil das vítimas e agressores em município do sul do Brasil. Texto contexto - enferm. Florianópolis, v.19, n.2, p.246-255, Jun 2010. Disponível em: http:// www.scielo.br/scielo.php?script=sci_arttext\&pid=S0104-07072010000200005\&lng=en\&nrm =iso>. Acesso em: 7 mar. 2020.

MINAYO, Maria Cecília de Souza (Org.). Pesquisa Social: teoria, método e criatividade. 19. ed. Petrópolis: Vozes, 2001.

NARVAZ, Martha Giudice. Submissão e resistência: explodindo o discurso patriarcal da dominação feminina. 2005. Programa de Pós-Graduação em Psicologia do Desenvolvimento, Universidade Federal do Rio Grande do Sul, Porto Alegre, 2005.

POPADIUK, Gianna Schreiber; OLIVEIRA, Daniel Canavese; SIGNORELLI, Marcos Claudio. A Política Nacional de Saúde Integral de Lésbicas, Gays, Bissexuais e Transgêneros (LGBT) e o acesso ao Processo Transexualizador no Sistema Único de Saúde (SUS): avanços e desafios. Ciênc. saúde coletiva, Rio de Janeiro, v. 22, n. 5, p. 1509-1520, maio 2017. Disponível em: <http://www.scielo.br/scielo.php?script=sci_arttext\&pid=S1413-81232017002501509\&lng= en\&nrm=iso>. Acesso em: 03 mar. 2020.

RIBEIRO, Maisa Elena; GOTO, Tommy Akira. Psicologia no sistema único de assistência social: uma experiência de clínica ampliada e intervenção em crise. Gerais: Revista Interinstitucional de Psicologia, v. 5, n. 1, p. 184-194, 2012.

ROSSATO, Lucas et al. Perfil de atendimentos psicológicos em contextos de violência sexual infantojuvenil: revisão integrativa da literatura. Contextos Clínicos, v. 11, n. 3, p. 297-309, 2018.

SAFFIOTI, Heleieth I.B. Contribuições feministas para o estudo da violência de gênero. Cad. Pagu, Campinas, n. 16, p. 115-136, 2001. Disponivel em: <http://www.scielo.br/scielo.php?script=sci_ arttext\&pid=S0104-83332001000100007\&lng=en\&nrm=iso>. Acesso em: 07 mar. 2020.

SINHORETTO, Jacqueline. Mapa do encarceramento: os jovens do Brasil. Secretaria Nacional da Juventude, 2015.

SCOTT, Joan. Gênero: uma categoria útil deanálise histórica. Educação \& realidade, v. 20, n. 2, 1995.

UNAIDS. OMS anuncia retirada dos transtornos de identidade de gênero de lista de saúde mental. In: UNAIDS. UNAIDS. [S. l.], 18 jun. 2018. Disponível em: https://unaids.org.br/2018/06/ oms-anuncia-retirada-dos-transtornos-de-identidade-de-genero-de-lista-de-saude-mental/. Acesso em: 5 mar. 2020. 
PARTE II

\section{ALIANÇAS, \\ ESTRATÉGIAS E \\ RESSIGNIFICAÇŌES}




\title{
GÊNERO, RAÇA E SEXUALIDADE: UMA PROPOSTA DE DEBATE INTERSECCIONAL?
}

\author{
Marco José de Oliveira Duarte \\ Dandara Felícia Silva Oliveira \\ Késia Mayra Rodrigues Ignácio
}

A proposta deste capítulo é problematizar o conceito de interseccionalidade que tem se popularizado academicamente, bem como tem estado em voga nas produções teóricas dos mais diversos saberes, mas, mais precisamente, pela sua importância para uma episteme negra ao pensar gênero, raça e sexualidade.

Raça, gênero, classe, sexualidade, território, identidade de gênero e religião são elementos que atravessam e constituem nossa escrevivência (EVARISTO, 2017), como sujeitas e pesquisadoras, pois escrevemos sobre nossas vivências, acrescentando dores e lutas. Assim emerge o conceito de interseccionalidade, a partir das escrevivências de mulheres negras que tentaram e ainda tentam romper com as estruturas sociais de exploração, opressão e dominação.

Para tanto, a proposta desse ensaio é apresentar esse debate interseccional a partir das autoras negras, que em tempos e espaços distintos da história elaboraram e fomentaram essa perspectiva teórica. $E$, em seguida, apontar outros elementos e questões que estão presentes na contemporaneidade desse mesmo debate.

\section{A interseccionalidade na cena do debate}

Antes de mais nada, é necessário demarcar que o conceito de interseccionalidade é utilizado há décadas pelas intelectuais e feministas negras, fruto da luta e da sensibilidade dessas. Anterior a sua existência, já ecoavam em múltiplas e plurais vozes de mulheres que questionavam o seu lugar no mundo dentro das estruturas de dominação sistêmicas e 
entrelaçadas. Lélia Gonzalez, Angela Davis, Patricia Hill Collins, Sojourner Truth, Carolina de Jesus e outras tantas, já demonstravam, questionavam e modificavam as encruzilhadas onde estavam inseridas.

Apesar de momentos e nacionalidades distintas, essas intelectuais já mostravam a repetição dessa estrutura de dominação, onde a mulher negra se localizava nas mais diversas encruzilhadas de opressão, ocupando ao mesmo tempo, uma espécie de vácuo, um não-lugar. Como afirma Kilomba (2020), a mulher negra é sustentada pela polarização, tanto na raça, quanto no gênero. Localizada como o Outro do Outro, visto que a negritude é situada como alteridade, esse Outro que não é o branco. Assim a feminilidade é branca e a negritude é masculina. Dessa forma, a mulher negra é subalternizada, a partir dessa falta de representação nas duas categorias. A autora nomeia essa dupla opressão como racismo genderizado. Como negro é homem e a mulher é branca, onde a mulher negra se encontra? A partir dessa falta de localização cria-se a interseccionalidade.

Akotirene (2019) nos oferece um recorte amplo da elaboração e utilização do conceito a partir das discussões de intelectuais negras, e, posteriormente, ampliada para academia. A autora demarca a interseccionalidade como um conceito fundado na sensibilidade analítica das feministas negras, cuja experiências e reinvindicações dessas eram inobservadas tanto pelo feminismo branco quanto pelo movimento antirracista.

Davis (2016), umas das pioneiras em incitar à necessidade de interseccionar os eixos de dominação, fornece-nos um resgate histórico intercalando os conceitos de gênero, raça e classe, desde a escravidão até a década de 1970, data cujo livro foi publicado. A autora denuncia como o movimento sufragista, e, posteriormente, Movimento de Direitos das Mulheres, era branco e elitista, silenciando as questões que atingiam diretamente as mulheres racializadas e pertencentes a classe trabalhadora. Da mesma forma que parte do Movimento Negro considerava as discussões de gênero e as denúncias de sexismo no interior do movimento como traição à raça ou fragmentação da luta antirracista.

No cenário brasileiro, Carneiro (2011) trata sobre os diferentes momentos da luta pelos direitos das mulheres, onde as temáticas específicas à mulher negra foram secundarizadas, baseado no princípio de universalidade de gênero. A especificidade da mulher negra era tratada invariavelmente como subitem da questão da mulher no geral, mesmo as 
afrodescendentes compondo metade da população feminina, tornando evidente que o movimento feminista brasileiro se recusava e se recusa a reconhecer à existência de uma dimensão racial imbricada na temática de gênero, estabelecendo assim privilégios e desvantagens entre as mulheres.

É nesse sentido que cabe destacar os tensionamentos produzidos por Lélia Gonzalez, uma das maiores expoentes na discussão de gênero, raça e classe no Brasil. A mesma tecia críticas referente à maioria dos militantes do Movimento Negro Unificado (MNU), pela falta de elaboração mais aprofundada sobre a mulher negra. Lélia torna-se, assim, a porta-voz contra o sexismo, que ameaçava subordinar a participação de mulheres no interior do MNU, e do racismo, que impedia a inserção plena de mulheres negras no Movimento de Mulheres. É essa intelectual que denunciava que as suas posturas, nesses espaços, eram enquadradas e lidas dentro do estereótipo de "negra raivosa", justamente por trazer para o debate as questões raciais ao movimento feminista.

Essa dificuldade do Movimento de Mulheres em reconhecer a diversidade interna do movimento é explicada pelo processo de recalque da dimensão racial, onde as minorias raciais tendem a serem excluídas. 0 esquecimento da questão racial pode ser interpretado como um caso de racismo por omissão, muito presente nos países da América Latina, que tentam apagar o seu processo de africanização. Em outras palavras, esse apagamento, mesmo daquelas que se dizem progressistas, tem por fim o apagamento cultural de origens indígenas e africanas oriundas da América Latina. É um pensamento neocolonial e eurocêntrico que mantém o status quo da estrutura societária.

Gonzalez (1984) postula sobre o lugar em que nos situamos determinará nossa interpretação sobre o duplo fenômeno do racismo e do sexismo. Segundo ela, o racismo se constitui como a sintomática que caracteriza a neurose cultural brasileira. Através da Psicanálise, a autora orienta a sua discussão sobre esse esquecimento racial. O neurótico constrói modos de ocultamento do sintoma, porque isso lhe traz certos benefícios, através desse esquecimento ele se liberta da angústia. Nessa perspectiva, o brasileiro pouco teria a dizer sobre a população negra e indígena. Exatamente porque essa neurose cultural passa a negar o estatuto de sujeito humano para a população negra, sendo colocado numa posição de objeto. É nesse sentido, que se compreende a resistência de certas análises que, ao insistirem na 
prioridade da luta de classes, se negam a incorporar as categorias de raça e sexo, insistem em as esquecer.

Nossos passos vêm de longe! Antes de Ângela Davis e Lélia Gonzalez tratarem e escancararem as desigualdades e abalarem as estruturas, no final do século XX, Sojourner Truth, abolicionista, não letrada e recém liberta, estremecia as estruturas no século XIX. Truth, em seu discurso que expunha a condição de não-mulher das mulheres negras, nunca antes discutida pelo movimento de mulheres, desfazia o mito do sexo frágil:

Arei a terra, plantei, enchi os celeiros, e nenhum homem podia se igualar a mim! Não sou eu uma mulher? Eu podia trabalhar tanto e comer tanto quanto um homem - quando eu conseguia comida - e aguentava o chicote da mesma forma! Não sou eu uma mulher? Dei à luz treze crianças e vi a maioria ser vendida como escrava e, quando chorei em meu sofrimento de mãe, ninguém, exceto Jesus, me ouviu! Não sou uma mulher? (GAGE; HARPER, 1881 Apud DAVIS, 2016, p. 71).

Essa retomada da interseccionalidade, antes de tornar-se um conceito, tem o objetivo de evidenciar que essa perspectiva já se encontrava nas discussões de intelectuais negras, a exemplo de Truth, que ainda é referência. Referência essa que revela tanto a permanência da exploração econômica, que atinge diretamente a mulher negra, como a violência de gênero, onde as mulheres racializadas são as maiores vítimas. Cabe mencionar o genocídio da juventude negra e o encarceramento em massa, onde a mulher negra continua nessa posição de não-muher, de simples procriadora, afastada de seu parceiro e filhos, revelando que o sistema colonial está longe de ser desfeito.

O conceito de interseccionalidade, como teoria crítica racial, foi cunhado pela intelectual afro-estadunidense Kimberlé Crenshaw. Entretanto, após a Conferência Mundial contra o Racismo, Discriminação Racial, Xenofobia e outras Intolerâncias Correlatas, em Durban, África do Sul, o termo conquistou a popularidade acadêmica, passando do significado inicialmente proposto para o esvaziamento, desconsiderando o feminismo negro como elo fundamental para essa análise. A princípio, o conceito visava dar instrumentalidade teórico-metodológica à inseparabilidade estrutural do racismo, capitalismo e patriarcado, eixos de dominação que se tornam 
produtores de avenidas identitárias, onde as mulheres negras são repetidas vezes atingidas pelo cruzamento e sobreposição de gênero, raça e classe, modernos aparatos coloniais (AKOTIRENE, 2019).

Crenshaw (2002) de forma didática e objetiva, utiliza uma metáfora da intersecção, fazendo uma analogia sobre os vários eixos de poder, sendo eles, raça, gênero, classe, sexualidade, nacionalidade e território, entre outros, que constituem as avenidas que estruturam os terrenos sociais, econômicos e políticos. É através dessas avenidas que as dinâmicas da opressão se movem. Essas vias são, por vezes, definidas como eixos de poder distintos e mutuamente excludentes. Em outras palavras, o racismo, é distinto do patriarcado, que por sua vez é diferente da opressão de classe. $\mathrm{Na}$ verdade, tais sistemas, frequentemente, se sobrepõem e se cruzam, criando intersecções complexas nas quais dois ou mais eixos se entrecruzam e se potencializam.

A autora evidencia como as mulheres racializadas, frequentemente, estão posicionadas em um espaço onde o racismo, a opressão de classe e o sexismo se encontram. Consequentemente, estão sujeitas a serem atingidas pelo intenso fluxo de tráfego em todas essas vias. As mulheres racializadas e outros grupos marcados por múltiplas opressões, localizados nestas intersecções em virtude de suas identidades específicas, devem negociar o tráfego que flui através dos cruzamentos. Tornando-se uma tarefa bastante arriscada, visto que o fluxo vem simultaneamente de várias direções, os mesmos estão sujeitos aos possíveis acidentes das encruzilhadas que se encontram. Por vezes, os danos são causados quando o impacto vindo de uma direção lança vítimas no caminho de outro fluxo contrário; em outras situações os danos resultam de colisões simultâneas (CRENSHAW, 2002).

Como já está evidenciado, o termo nasce do feminismo negro, Akotirene (2019) destaca: "é da mulher negra o coração do conceito de interseccionalidade”. Gonzalez (1984) já evidenciava a necessidade de aprofundar essa reflexão. Sendo colocada como uma saída frente à reprodução e à repetição dos modelos que eram oferecidos pela investigação das ciências sociais e de outros saberes, compostos, majoritariamente, pela branquitude. Demonstrando, assim, uma fragilidade na discussão, cuja mulher negra era localizada apenas numa perspectiva socioeconômica, sem elucidar o racismo que a atingia. A autora menciona a existência permanente de um resto que desafiava as explicações e isso começou a incomodar. 
O feminismo negro dialoga entre e nas encruzilhadas, denominadas avenidas identitárias, principalmente, as opressões produzidas pelo racismo, cisheteropatriarcado e capitalismo. O conceito produzido nesse campo discursivo precisa se tornar pautas em outros setores de lutas, como o movimento LGBTQIA+, as pessoas deficientes, os indígenas, os religiosos de matrizes africanas e a classe trabalhadora. Dessa forma, Akotirene (2019) pontua que dentro da perspectiva decolonial - uma visão crítica e contrária ao eurocentrismo - é indicado empregar interseccionalidade para localizar apenas discriminações e violências institucionais contra setores marginalizados pela sociedade, como os grupos já citados acima. A interseccionalidade surge como uma ferramenta para localizar aquele que é tido como o Outro, esse que foge da cisheteronormatividade compulsória, da branquitude, do patriarcado, e de outras estruturas de dominação.

Dessa forma, é fundamental salientar que a perspectiva interseccional impede hierarquização ou comparação entre cada eixo de opressão. Ao invés de uma análise somatória, analisa-se quais condições estruturais que atravessam os corpos, por serem experiências modeladas por e durante a interação das estruturas. Portanto, a identidade não pode se abster de nenhuma das suas marcações, mesmo que nem todas, contextualmente, estejam explicitadas (AKOTIRENE, 2019).

Dito isso, devemos nos afastar dos discursos de análises somatórias ou aditivas da opressão, nos quais ocorrem a visão dicotômica opressor/ vítima e a categorização da opressão. Através de análises somatórias, as mulheres negras são vexadas como sendo as mais oprimidas que todas, já que a maioria das mulheres negras experimenta os efeitos negativos das opressões de raça, classe e gênero simultaneamente. Em essência, se juntássemos as diferentes opressões, teríamos uma opressão maior do que a soma de suas partes. Collins (2015) traz o questionamento se os eixos de opressão se cruzam e se potencializam, porque deveríamos analisar como se houvessem diferenças matemáticas entre eles?

Crenshaw (2002) enfatiza que o objetivo dessas topologias iniciais, que tange a interseccionalidade, é propor uma linguagem capaz de expressar as experiências das pessoas e, também, de ilustrar a necessidade de expandir os parâmetros conceituais dos tratados internacionais vigentes. Como mostram as topologias, o problema interseccional não está simplesmente no fato de não abordar um único tipo de discriminação de forma completa, 
mas no fato de uma amplitude de violações, as quais ficariam invisibilizadas caso não se considerassem as vulnerabilidades interseccionais.

A autora transforma em um escopo teórico-metodológico um problema que outras intelectuais negras já apontavam, presente dentro do Movimento de Mulheres e do Movimento Negro. O duplo problema da superinclusão e da subinclusão. A superinclusão ocorre na medida em que os aspectos que o tornam um problema interseccional são absorvidos pela estrutura de gênero, sem qualquer tentativa de reconhecer o papel de outros eixos de dominação. Por outro lado, a subinclusão ocorre quando existem distinções de gênero entre homens e mulheres da mesma raça. Frequentemente, quando uma condição ou problema é específico das mulheres racializadas, é posto como improvável que essa discriminação venha a atingir os homens, sua identificação como problema de subordinação racial fica comprometida, sendo invisibilizado.

Criticar essa visão dicotômica de vítima/opressor, é essencial para que seja nítido reconhecer o pedaço do opressor que existe em nós. A maioria de nós tem facilidade em acessar as próprias discriminações sofridas, dentro de algum amplo sistema de opressão, seja ela por raça, classe social, religião, orientação sexual, etnia, idade ou gênero. Porém, falhamos em nos ver como nossos reprodutores ou mantenedores da subordinação de outras pessoas (COLLINS, 2015).

A interseccionalidade é uma forma de entender como um eixo de opressão se sobrepõe ao outro. Dessa forma, Akotirene (2019) afirma que a classe pode dizer da raça, da mesma forma que raça informa sobre classe. Posto em evidência a complementaridade dos eixos de opressão, a temática economicista se torna assim limitante, visto que a discriminação não passa de um instrumento manipulado pelo capitalista que visa, mediante a exploração das minorias raciais, dividir o operariado. A solução seria a aliança entre trabalhadores de diferentes raças, ou seja, a intersecção das lutas, ao invés de sua divisão (GONZALEZ, 2020). Gonzalez escurece a discussão:

Nesse momento, poder-se-ia colocar a questão típica do economicismo: tanto brancos quanto negros pobres sofrem os efeitos da exploração capitalista. Mas na verdade, a opressão racial faz-nos constatar que mesmo os brancos sem propriedade dos meios de produção são beneficiários do seu exercício. Claro está que, enquanto o capitalista branco se beneficia 
diretamente da exploração ou super-exploração do negro, a maioria dos brancos recebe seus dividendos do racismo, a partir de sua vantagem competitiva no preenchimento das posições que, na estrutura de classes, implicam nas recompensas materiais e simbólicas mais desejadas (GONZALEZ, 2020, p.35).

Neste trecho é reafirmado como a supremacia branca capitalista consegue tornar o sujeito como opressor e vítima dentro de um mesmo sistema. A fragmentação das lutas colabora na manutenção dessa supremacia. Deteriorando a capacidade do sujeito de se reconhecer como produtor de violações, perpetuando assim a exploração econômica das minorias raciais. Segundo Collins (2015), cada grupo identifica o tipo de opressão que se sente mais à vontade em atribuir como fundamental e classifica todos os outros tipos como menos importantes.

Davis (2018), como uma das pioneiras do pensamento interseccional, afirma que o conceito também é entendido como esforços de reflexão, análise e organização, que reconhece as interconexões entre raça, classe, gênero e sexualidade que evoluiram consideravelmente nas últimas décadas. A autora define sua obra não como uma análise individual, ao contrário, a interseccionalidade surge para ela como uma percepção do interior dos movimentos e coletivos, posto a impossibilidade de separação das questões raciais, de classe e de gênero. Portanto, por trás do conceito, há histórias de lutas.

A interseccionalidade é colocada, pela autora, como uma construção de diálogos entre intelectuais acadêmicos e ativistas dos movimentos sociais, salientando que o pensamento interseccional também foi germinado fora das análises acadêmicas, surgindo de experiência pessoais e coletivas. A autora coloca que o corpo não é separado dos eixos de opressão, assim como as lutas. Apontando que o mais interessante, dentro dessa construção, dada essa longa história tanto de ativismo como de produção acadêmica, é a conceitualização da interseccionalidade das lutas. Inicialmente, o conceito se referia aos corpos e às experiências, mas agora atingiu a união e a solidariedade entre várias lutas por justiça social, para além de fronteiras nacionais.

Davis (2018) aponta sobre como as opressões estão interligadas, fato que se tornou evidente com o Movimento Black Lives Matter (Vidas Negras 
Importam), que surgiu nos Estados Unidos da América (EUA) e teve uma repercussão internacional. Devido a globalização e ao aumento do acesso as redes sociais, a morte de João Alberto, em novembro de 2020, homem negro assassinado por seguranças dentro da rede de supermercados Carrefour, em Porto Alegre, tornou-se extremamente associada ao assassinato de George Floyd, vítima de violência policial nos EUA, no começo desse ano. Ambas as violações também estão associadas com a questão da Palestina, pois tem o mesmo denominador em comum, o mesmo opressor, a supremacia branca capitalista.

A importância da perspectiva interseccional, segundo Crenshaw (2002), reside não apenas no valor das descrições mais precisas sobre as experiências vividas pelo sujeito de maneira singular, mas também no fato de que intervenções baseadas em compreensões parciais e, por vezes, distorcidas das condições desse sujeito, muito provavelmente, são ineficientes e talvez até contraproducentes. Somente através de um exame mais detalhado das dinâmicas variáveis que formam a subordinação de determinados grupos, é possível desenvolver intervenções e proteções mais eficazes.

É nesse sentido, portanto, que Gonzalez (1984), ao entrelaçar as questões de gênero, raça, classe e território, evidenciava a posição que a mulher negra ocupava, e ainda ocupa, na sociedade brasileira, como "doméstica" ou "mulata". Tais papéis sociais naturalizados fomentam a exploração econômica e sexual específicas às mulheres negras.

A autora também engendra o território em suas discussões, abordando o lugar naturalizado do negro nas senzalas, favelas, cortiços, invasões, alagados e conjuntos habitacionais. Além da presença policial, não para proteção, mas para reprimir, violentar e matar. Portanto, um outro lugar naturalizado do negro, as prisões, em decorrência da sistemática repressão policial e seu conteúdo racista.

Ademais, um dos legados concretos da escravidão diz respeito à distribuição geográfica da população negra, isto é, à sua localização periférica em relação às regiões e setores hegemônicos. Dessa maneira, as opressões se imbricam e se potencializam, produzindo diversas encruzilhadas de dominação para as vidas negras. 


\section{Gênero, raça e sexualidade - uma proposta de debate interseccional}

Propõe-se a análise da interseccionalidade entre gênero, raça e sexualidade, trazendo a questão da necessidade de aprofundar o debate, se apropriando do conceito das feministas negras afrolatinoamericanas. O intuito é fazer um diálogo sobre essa questão, analisando artigos que procuram fazer esse debate interseccional.

Para esse ensaio, traremos primeiro as mulheres lésbicas pretas, depois as bichas pretas e, por último, as transvestigêneres pretas. A proposta é evidenciar de que maneira a interseccionalidade gênero, raça e sexualidade marcam e constroem identidades, definem lugares e produzem enquadramento, como proposto por Butler (2019b).

Segundo a autora, a mídia se torna responsável em atribuir valor a uma vida para que ela seja perceptível como vida. Nesse sentido a comoção depende de apoios sociais para o sentir. Nós só conseguimos sentir e reivindicar a comoção social depois que já estamos inscritos nela. Desta maneira, não é só uma dicotomia entre humanos e desumanizados. É, antes a desumanização que produz a humanização do outro, é a civilização ocidental com todas as suas "regras", contra o resto que por definição é ilegítimo (BUTLER, 2019a). Esses enquadramentos não só definem quem pode viver, ou que, em outras palavras, produzem a vida num continuum, mas também constroem ontologias de sujeitos específicos (BUTLER, 2019b)

O conceito de enquadramento é operado aqui para problematizar de como os corpos LGBTQIA+ negros são tratados e enquadrados em uma sociedade cisheterossexista branca.

As lésbicas negras lutam para romper com o preconceito, por uma visibilidade respeitosa e para conquistar os mesmos direitos civis de que gozam as pessoas brancas heterossexuais. A utilização do pensamento interseccional para pensar as desigualdades, preconceito e discriminação pode ser uma ferramenta metodológica para localizar um eixo particular e específico, onde vários outros eixos de desigualdade, preconceito e discriminação se cruzam (EXALTAÇÃO, 2018, p. 119). 
A autora acima, em sua análise, revela como homofobia, racismo e sexismo colocam mulheres negras não heterossexuais numa interseccionalidade que podem ser dispositivos marginalizadores no seu próprio lugar de luta. A recorrência de reclamações de mulheres negras lésbicas que se veem discriminadas nos diversos movimentos que compõem, seja no LGBTQIA+ e no de mulheres sofrendo racismo, seja no de negro, sofrendo lesbofobia ou bifobia. Esse enquadramento, portanto, produz um sujeito outsider, revelando que as interssecionalidades marcam as desigualdades que existem.

Santos (2018) compreende que raça, classe, gênero e sexualidade são elementos que estabelecem códigos que são fortalecidos mutuamente, formando um sistema específico de opressão. Portanto, não sendo assim categorias análogas, a autora cita a impossibilidade de priorizar uma frente de luta por possuir identidades interseccionais, como de mulher, negra, lésbica e nordestina. Ressalta, assim, que essas identidades são as que interseccionalmente sofrem explorações e colocam essa sujeita e tantas outras em um lugar naturalizada e socialmente subalterno.

É nesse sentido que Butler (2019b) afirma:

A distribuição diferencial da condição de precariedade é ao mesmo tempo uma questão material e perceptual, porque apenas as vidas que não são consideradas lamentáveis e valiosas são obrigadas a suportar a carga de forme, subemprego, da privação de direitos e da exposição à violência e à morte (BUTLER, 2019b, p. 46-47).

A interseccionalidade de gênero, raça e sexualidade precariza ainda mais a vida já precarizada em sua geração. $O$ corpo abjeto que não se deixa adaptar a uma homonormatividade branca, traz para si a condição de não enlutável, de precariedade e de desmerecimento.

No bojo da teoria queer e dos estudos decoloniais criou-se, no Brasil, para definir homossexuais não homonormativos e racializados, a composição "bicha preta". Chagas (2018) vem descrever o corpo da bicha preta e como a interseccionalidade a atinge a partir da visão do corpo branco heterossexual, levando o corpo da bicha preta para a margem, para o lugar de ser temido, desprezado e precariado. 
Para Simões et al. (2010), em uma pesquisa que traz também relatos diretos, é possível perceber o quanto o construto da homonormatividade branca atravessa e intersecciona o corpo da "bicha preta". Segundo os autores, um dos seus entrevistados era eloquente ao dizer como racismo, sexismo e misoginia faziam parte do cotidiano de homens homossexuais que não aderem a norma corrente. É assim que Pedro, em entrevista, relata suas experiências:

Existe um padrão gay que todos os gays amam: é cabelo liso, branquinho, traços finos, europeus. Todos os gays valorizam isso. Então, se você não tem isso, vem a famosa gongação. Uma bicha gongada é uma bicha que não se encaixa nos padrões que os gays acham legal, que não se veste com roupa na moda ou de marca, entendeu? Que não tem o cabelo hiperproduzido, alisado... Gay adora gongar o outro, adora criticar! Então, gay negro sofre muito! Ai, que cabelo ruim! Ai, esse nariz! Nossa, já peguei tanta situação com outras pessoas. Mais pelo cabelo, né?! Porque meu cabelo está cuidadinho agora, mas antes meu cabelo estava num aspecto mais natural mesmo, sabe? Então, nossa, me gongavam muito! Ai, que cabelo, esponjaço, assolan! (SIMÕES et al, 2010, p. 55).

Sant'ana (2010), analisando a representatividade negra nas capas das revistas gays demonstra mais uma vez a existência de um padrão homonormativo que não considera a interseccionalidade de gênero, raça e sexualidade. Pensando qual era, à época, o padrão de gay que era representado na revista e se questionando se as bichas pretas se sentiriam representadas naquela revista, o autor evidencia que além do padrão homem, branco, cisheteronormativo, outras identidades interseccionais são interpostas nessa representatividade, tais como raça, escolaridade e classe, revelando a invisibilidade do corpo preto nas publicações.

Uma outra forma de perceber como a interseccionalidade de gênero, raça e sexualidade é percebida pelos sujeitos é através da violência sofrida por esses sujeitos. Para França (2018), essa interseccionalidade faz com que homossexuais negros, mestiços, efeminados, periféricos e pobres estejam mais sujeitos aos preconceitos e desamparados frente à violência homofóbica individual ou perpetrada pela estrutura do Estado. 
Assim, a interseccionalidade de gênero, raça e sexualidade atravessa os corpos transvestigêneres. Ressalta-se, nesse particular, Xica Manicongo. Jesus (2019) quem nos traz a descrição de tão importante personagem histórica para a imagem coletiva de corpos transvestigêneres racializados. Descreve a autora:

Coberta com um pano que prendia com o nó para frente, à moda dos quimbanda de sua Terra Natal, e apesar de sua condição desumanizada, imposta pelos homens brancos, os candangos, ela andava sobranceira por toda Cidade Baixa, às vezes subindo para a Cidade Alta e voltando, a serviço do seu senhor, ou só passeando, inclusive para encontrar os seus homens. Diz-se que Xica era conhecida por ser muito namoradeira. Mesmo no inferno da escravidão havia frestas, sempre escavadas pela gente negra (JESUS, 2019, p. 252).

É Xica quem traz a força para que hoje diversos corpos transvestigêneres ocupem espaços de poder e decisão, como da universidade, que é um lugar, segundo Silva (2019), que se decide quais corpos poderão ser estudados e quais os enquadramentos se darão a esses corpos.

É com base nesse sistema, portanto, que a autora afirma que muitas vezes, para uma mulher transexual negra existir em um espaço quadruplamente negado é preciso gritar, talvez gritar para mostrar que aquele corpo existe num continuum que não pode desconsiderar suas subjetividades, num processo que não pode ver negado para si o afeto, a vivência e a permanência nesses espaços.

Portanto, é preciso inclusive perceber os matizes dos olhares que distinguem aqueles que tem a interseccionalidade vivida e os outros que são a normatividade. A questão da interseccionalidade, segundo a autora, fica no questionamento que ela se fez: qual opressão tinha se dado primeiro, a transgeneridade ou a questão racial? Para Silva (2019), é necessário interseccionalizar o conceito porque também para mulheres cisgênero, a raça engendra lugar de poder sobre o corpo. Assim, gênero e raça são dispositivos relacionais que fazem com que pouco importe o que venha primeiro, sendo que um e outro baseiam-se em dinâmicas de exclusão e de precarização dos corpos.

Como nos afirma Kilomba (2020), 
Experiências cotidianas de racismo, indicando um doloroso impacto corporal e a perda característica de um colapso traumático, pois no racismo o indivíduo é cirurgicamente retirado e violentamente separado de qualquer identidade que ele/ela possa realmente ter. Tal separação é definida como um trauma clássico, uma vez que priva o indivíduo de sua própria conexão com a sociedade inconscientemente pensada enquanto branca (KILOMBA, 2020, p. 176).

Por outro lado, refletindo com Jesus e Alves (2010; 2018) em suas produções, ao tratarem da interseccionalidade para debater dispositivos precarizadores dos corpos transvestigêneres. As autoras apontam que a ideia de que a visibilização maior da população trans se dá em um projeto político de emancipação, relacionado à sua publicização. Assim, tal qual as mulheres negras na história do feminismo, que perceberam na interseccionalidade a forma estratégica de demonstrar que determinadas parcelas desse movimento não considerava a necessidade de todas as mulheres, esse mesmo feminismo que está em suas bases, não considera a interseccionalidade de gênero, raça e sexualidade dos corpos transvestigêneres pretos, considerando o corpo cisheteronormativo branco como o corpo verdadeiro.

Jesus e Alves (2018), sinalizam que:

É praxe das mídias menos atentas à pluralidade do feminino reforçar estereótipos sobre o que é ou não ser mulher. As referências visíveis de mulher tendem a remeter apenas às brancas, abastadas e magras, ignorando que há as negras, indígenas, gordas, lésbicas, pobres, transexuais. Nessa última dimensão, na qual se demonstra que nem a biologia nem a anatomia determinam o que é uma mulher, o peso de uma suposta "verdade" prepondera e discrimina (JESUS; ALVES, 2018, p. 12)

Assim, é a partir das novas ideias do movimento feminista, influenciado pelo movimento feminista negro interseccional que a percepção sobre quem são as mulheres se amplia e começa-se a abarcar novas possibilidades de mulheres: negras, dos povos originários, mulheres com deficiência, lésbicas, bissexuais e mulheres transvestigêneres. 
Vergueiro (2015) aponta de que é necessário pensar que somente a "passabilidade" talvez não seja a única estratégia para a prevenção contra a violência cissexistas, mas que talvez seja necessário realizar uma análise interseccional para compreender quais são as barreiras racistas e elitistas que colocam a fronteira em quem fica passável ou não.

Nesse sentido é preciso pensar que, particularmente sobre os corpos transvestigêneres, a intereseccionalidade de dispositivos afeta de maneira desigual o impacto das violências sobre "pessoas trans travestis negras, pobres, não cristãs, prostitutas e positivas" (VERGUEIRO, 2015, p. 211) e que as iniciativas de transformação sociocultural devem, de maneira crítica, segundo a autora, trazer para a centralidade a discussão da interseccionalidade de gênero, raça e sexualidade para a construção de políticas públicas que vão afetar diretamente essa população.

A respeito dos corpos transvestigêneres e interseccionalidade, Santos e Duque (2019) tratam de um debate a respeito das lutas e resistências de pessoas transvestigêneres através da música da cantora Linn da Quebrada, ao retratar em suas músicas os sujeitos como sendo as 'bichas' afeminadas, as 'bichas' pretas, as 'bichas' travestis, as pessoas trans e todos os corpos que não cabem em um padrão normativo. Para Santos e Duque (2019), a "bixa preta" é o corpo marcado pela sexualidade, etnia/raça, geografia e socialmente marginalizado que denuncia esse não caber em muitos espaços sociais e, por isso, recebe o deboche.

Para os autores, a cantora deixa evidente a todo momento a sua problematização de conceitos naturalizados para revisar conceitos já estabelecidos de abjetos e dissidentes, possibilitando construções de identidades, principalmente, pautadas nas intersecções as quais Linn é alocada como travesti, preta e periférica. 


\section{Considerações Finais}

Não temos a pretensão nesse ensaio de esgotar o tema. Ao contrário, nossa proposta, nesse momento, vem ao encontro dos nossos anseios em tentar sugerir o debate de gênero, raça e sexualidade, sob a ótica teóricometodológica do conceito de interseccionalidade.

Nesse sentido, nossos esforços se dão em trazer um panorama de autores, sejam feministas negras, sejam outras pessoas que debatam o tema, para tentar, de maneira ainda preliminar, aumentar o enfoque sobre as questões interseccionais de gênero, raça e sexualidade. Portanto, como já afirmamos, propusemos trazer o conceito de interseccionalidade cunhado por Creenshaw e explorado na primeira parte desse texto e, em seguida, iniciar um debate introdutório sobre os corpos pretos de sapatões, bichas e transvestigêneres.

Assim, esperamos ter contribuído de alguma maneira para ampliar o debate conceitual tão importante por sua estratégia, entendendo que a questão é estrutural, por isso que compartilhamos da perspectiva de uma sociedade antirracista, antiLGBTQIAfóbica, antiheterosexista e anticapitalista para o bem viver. 


\section{REFERÊNCIAS}

AKOTIRENE, C. Interseccionalidade. São Paulo: Pólen, 2019.

BUTLER, J. Vida precária: os poderes do luto e da violência. Belo Horizonte: Autêntica, 2019a.

BUTLER, J. Quadros de guerra: Quando a vida é passível de luto? 6.ed. Rio de Janeiro: Civilização brasileira, 2019b.

CARNEIRO, S. Racismo, sexismo e desigualdade no Brasil: consciência em debate. São Paulo: Selo Negro, 2011.

CHAGAS, A. R. Quem chora pelas bichas? As marcas queimadas a ferro na pele-corpo de bichas pretas. Anais do III Encontro de Antropologia Visual da América Amazônica. Belém: UFPA, 2018.

COLLINS, P. H. Em direção a uma nova visão: raça, classe e gênero como categorias de análise e conexão. MORENO, R. (Org.). Reflexões e práticas de transformação feminista. São Paulo: SOF, 2015.

CRENSHAW, K. Documento para o encontro de especialistas em aspectos da discriminação racial relativos ao gênero. Revista Estudos Feministas, Florianópolis, v. 10, n. 1. p. 171-188, 2002.

DAVIS, A. A liberdade é uma luta constante. São Paulo: Boitempo, 2018.

DAVIS, A. Mulheres, raça e classe. São Paulo: Boitempo, 2016.

EVARISTO, C. Becos da memória. Rio de Janeiro: Pallas, 2017.

EXALTAÇÃO, Edmeire. Lésbicas negras: ativismo, orgulho e visibilidade política. In: CAETANO, M. et al (Org.). Quando ousamos existir: itinerários fotobiográficos do movimento LGBTI Brasileiro (1978-2018). Tubarão; Rio Grande: Copiart; FURG, 2018.

FRANÇA, A. N. M. Movimentos sociais e o programa Rio sem homofobia: uma trajetória de luta por políticas públicas e o reconhecimento da cidadania LGBT no Rio de Janeiro. 2018. 155f. Dissertação (Mestrado em Políticas Públicas em Direitos Humanos). NEPP-DH, UFRJ, Rio de Janeiro, 2018.

GONZALEZ, L. Racismo e sexismo na sociedade brasileira. In: SILVA, L. A. et al. Movimentos sociais urbanos, minorias e outros estudos. Ciências Sociais Hoje, Brasília, ANPOCS, n. 2, p. 223-244, 1984.

JESUS, J. G. de; ALVES, H. Feminismo transgênero e movimentos de mulheres transexuais. Revista Cronos, Natal, v. 11, n. 2, 2010.

JESUS, J. G. de; ALVES, H. Feminismos contemporâneos e interseccionalidade 2.0 Uma contextualização a partir do pensamento transfeminista. REBEH, Fortaleza, v. 1, n. 1, p. $5-24,2018$.

JESUS, J. G. de Xica manicongo: a transgeneridade toma a palavra. Revista Docência e Cibercultura, Rio de Janeiro, v. 3, n. 1, p. 250-260, janeiro/abril de 2019. 
KILOMBA, G. Memórias da plantação: episódios de racismo cotidiano. $2^{\circ}$ reimpressão. Rio de Janeiro: Editora Cobogó, 2020.

RIOS, F.; LIMA, M. (Org.). Por um feminismo afro-latino-americano: Lélia Gonzalez. Rio de Janeiro: Zahar, 2020.

SANT'ANA, T. Bicha preta, pobre e afetada? Aqui não, hein?! - Corpo e identidade homossexual na revista gay A Capa. In: DEL BIANCO, N. R. et al. (Org.). Comunicação, Cultura e Juventude: Anais do XII Congresso de Comunicação da Região Nordeste, 10 a 12 de junho de 2010, São Paulo; Campina Grande: Intercom; UEPB, 2010.

SANTOS, A. C. C. Negra e lésbica - ativismo interseccional In: CAETANO, M. et al (Org.). Quando ousamos existir: itinerários fotobiográficos do movimento LGBTI Brasileiro (1978-2018). Tubarão; Rio Grande: Copiart; FURG, 2018.

SANTOS, A. D. dos; DUQUE, T. Eu gosto mesmo é das bixas: reflexões sobre identidade ao som de Linn da Quebrada. Revista Docência e Cibercultura, Rio de Janeiro, v. 3, n. 1, p. 13-37, janeiro/abril de 2019.

SILVA, M. R. Devir selvagem: a arte do grito (ou do grito na arte). Revista Docência e Cibercultura, Rio de Janeiro, v. 3, n. 1, p. 51-72, janeiro/abril de 2019.

SIMÕES, J. A.; FRANCA, I. L.; MACEDO, M. Jeitos de corpo: cor/raça, gênero, sexualidade e sociabilidade juvenil no centro de São Paulo. Cadernos Pagu, Campinas, n. 35, p. 37-78, dez., 2010.

VERGUEIRO, V. Por inflexões decoloniais de corpos e identidades de gênero inconformes: uma análise autoetnográfica da cisgeneridade como normatividade. 2015. 244 f. Dissertação (Mestrado em Cultura e Sociedade). Instituto de Humanidades, Artes e Ciências Professor Milton Santos, da Universidade Federal da Bahia, Salvador, 2015. 


\title{
BRUXAS, LOUCAS OU MÁS: ABORTEIRAS NO ENTRE DE FEITIÇOS E PROBLEMAS
}

\author{
María Antonella Barone \\ Alexsandro Rodrigues \\ Pablo Cardozo Rocon
}

\begin{abstract}
No discurso vigente em minha infância, criar problema era precisamente o que não se devia fazer, pois isso traria problemas para nós. A rebeldia e sua repressão pareciam ser apreendidas nos mesmos termos... A lei dominante ameaçava com problemas, ameaçava até nos colocar em apuros, para evitar que tivéssemos problemas [...]. Os problemas são inevitáveis e nossa incumbência é descobrir a melhor maneira de criá-los (BUTLER, 2003, p. 7).
\end{abstract}

O aborto é um fenômeno frequente e persistente entre todas as classes sociais, relações raciais, níveis educacionais e religiões: segundo a Pesquisa Nacional do Aborto (PNA) realizada em 2016 e publicada em 2017, uma pessoa por minuto pratica aborto no Brasil. Isso significa dizer que uma a cada cinco pessoas entre 18 e 39 anos já fez um aborto. Ou seja, 4,7 milhões de mulheres já abortaram. Embora se reconheça a importância desta pesquisa de nível nacional, assim como outros informes que fornecem estatísticas, a pesquisa se fez com somente mulheres cisgênero.

É difícil dimensionar a magnitude deste problema devido à subnotificação por ser uma prática considerada crime, e ao fato de que, a informação inclusa nestas pesquisas é limitada à quantidade de abortos realizados por mulheres cis, segundo a suposição de que são estes sujeitos, as únicas pessoas que abortam. É dizer, não contabilizam as práticas abortivas de todos os corpos com capacidade de gestar e que não se encaixam na categoria "mulheres" circunscritas em normas binárias e heteronormativas para os gêneros. Normas que produzem uma verdade sobre os gêneros como reflexos de estruturas corporais e biológicas, da sexualidade como regulada segundo a heterossexualidade e assim, a gestação como realidade 
possível aos corpos binarizados em seus gêneros e postos em relação de complementariedade por uma heterossexualidade compulsória.

Nesses termos, ficam de fora, por exemplo, os homens trans, pessoas transmasculinas, corpos não binários, pessoas trans que foram assignadas com um feminino ao nascer, entre outras possibilidades de existência. Dessa forma, quando Butler (2003) fala que os problemas são inevitáveis e que a nossa incumbência é descobrir a melhor maneira de fazê-los, de criá-los, uma frase evocada por alguns movimentos feministas: "Precisamos Falar sobre Aborto", nos convoca e nos provoca à problematização.

Ao dizermos que precisamos falar sobre aborto, optamos por utilizar uma palavra que designa uma prática carregada de significados que foram e são produzidos sobre essa. Jorge Larrosa (2015, p. 16-17) afirma que as "palavras produzem sentido e criam realidades (...). Cremos que fazemos coisas com as palavras e, também, que as palavras fazem coisas conosco. As palavras determinam nosso pensamento porque não pensamos com pensamentos, mas com palavras". Fazemos então, coisas com a palavra aborto, que é uma expressão utilizada, muitas vezes, pelos movimentos que se manifestam contra a prática, contra a escolha e a favor dos nascimentos, equiparando-o a assassinato e relacionando-o a infanticídio, morte, pecado, inferno e coisas do tipo. Mas, também, é um termo apropriado e utilizado pelos movimentos que reivindicam o direito ao acesso à autodeterminação sobre se parir ou abortar.

Então, elegemos nomear à prática com o termo aborto e nos apropriar do lugar semântico para produzir outros sentidos, sem desestimar as controvérsias e limitações da palavra. Isso porque compreendemos também que "as lutas pelas palavras, pelo significado e pelo controle das palavras, pela imposição de certas palavras e pelo silenciamento ou desativação de outras são lutas em que se joga algo mais do que simplesmente palavras, algo mais que somente palavras" (LARROSA, 2015, p. 18). Não propomos aqui uma batalha terminológica porque pensamos que, diferentemente de se constituir belicoso, a escolha pelo uso do termo aborto é uma aposta para reafirmá-lo como prática que, muitas vezes, é assim nomeada pelas pessoas que o vivenciam. Apropriarmo-nos do termo e propormos uma abertura para problematizar o que é produzido sobre ele. Dessa forma, faz-se necessário dispor o termo "aborto" para novas significações. 
Ampliamos, assim, a possibilidade dos movimentos com a palavra aborto que tentam fugir das produções que se conectam a algumas instituições que regulam os discursos e os (des)legitimam (família, escola, mídia, instituições jurídicas, médicas e religiosas, por exemplo). Elas utilizam expressões como "interrupção voluntária da gravidez" e/ou "interrupção da gestação/concepção". O exercício de diálogo com essas instituições é fundamental na conversação transdisciplinar entre saberes que, mesmo sendo difícil, acontece. Assumimos o compromisso desses intercâmbios para a ação conjunta de quem nos importamos com a vida dos corpos que abortam. Exemplos disso são os coletivos de médicas e médicos pela escolha, católicas pelo direito de decidir, evangélicas pelo direito de decidir, advogadas feministas pró-choice, entre outros.

Contudo, aos efeitos deste trabalho, preferimos ocupar o lugar do termo aborto porque desde a escrita permite-se uma circulação do que enunciamos e, assim, vai pertencer a outras que recebem na leitura. Com isso, dizemos que estamos no exercício de ouvir a palavra do corpo. Consideramos que a escolha pelas palavras é visão de mundo, então, tomamos posição e produzimos enunciados que se tornam públicos para co-produzir conhecimentos sobre o aborto. Notamos que, no uso da expressão "interrupção voluntária da gravidez", por exemplo, existe a enunciação do processo da "gravidez", cujo termo, já tem um multiverso de produção de sentidos em torno dele. Dessa forma, perguntamo-nos: as pessoas que abortam, utilizam uma expressão que contém em si mesma o universo semântico relacionado à "gravidez"? Ou fogem dela e utilizam outras? Afirmar a palavra aborto traz a possibilidade de visibilizar a prática como uma estratégia política, subvertendo as definições para evocar a coletivização dos afetos atrelados à experiência de abortar.

Enquanto os usos de determinadas palavras e não outras, pensamos também na utilização do termo "aborto" nas redes sociais como "ciberativismo" ou "narrativas digifeministas" (DE ABREU, 2017, p. 145) e o uso de hashtags, que servem "para organizar blocos de discussão temática", sendo assim, "capazes de reunir multidões em torno de questões pontuais e ao mesmo tempo universais" (DE ABREU, 2017, p. 146). A utilização de hashtags gera uma influência na difusão de informações, tendo como um exemplo emblemático o caso Belén, na Argentina, e a campanha que seguiu através do Twitter com hashtags \#LibertadParaBelén e \#AbortoLegal. O movimento do "caso Belén" foi suscitado pela punição de uma jovem 
argentina que foi condenada a oito anos de prisão por um aborto espontâneo. Às mobilizações e os reclamos para a liberação de Belén, se somaram campanhas no ciberespaço e a palavra aborto apareceu munindo as redes e alcançando milhares de menções. Isso possibilita a realização de pesquisas, por exemplo, das tecnologias da informação e comunicação, que façam mapeamentos da quantidade de vezes que se digitou uma palavra ou uma frase replicando-se no mundo e, assim, estudar o alcance dessas campanhas através da internet. Redes sociais, como Twitter e Facebook, utilizam ferramentas de monitoramento num período de tempo determinado para obter gráficos com informações em relação à rede específica de conexões. Utilizando dessas ferramentas, podemos observar que, no dia 28 de setembro, dia latinoamericano de luta pela legalização e descriminalização do aborto, as redes são abastecidas pelas hashtags \#28set, \#LegalizaOAborto e \#AbortoLegal, constituindo um grito comum e permitindo "abordagens metodológicas como a netnografia e a análise de conteúdo" (DE ABREU, 2017, p. 137), nas pesquisas nos espaços digitais.

Consideramos importante destacar a utilização do termo aborto nas pesquisas com internet porque "as máquinas tecnológicas de informação e de comunicação operam no núcleo da subjetividade humana, não apenas no seio das suas memórias, da sua inteligência, mas também da sua sensibilidade, dos seus afetos" (GUATTARI, 1992, p. 14). Acreditamos na capacidade de contágio que ultrapassa reivindicações ideológicas e descarrega o aborto de matizes morais para possibilitar uma entrega às experiências e narrativas ensanguentadas em um devir aborteiras.

Aborteiras são as pessoas que fazem acontecer os abortos, que colaboram nos processos de aborto, que não podem ser identificadas. São as vizinhas, as amigas, os companheiros, as companheiras, as doulas, os médicos, as médicas, os enfermeiros, as enfermeiras, enfim. São todas aquelas pessoas que conhecem histórias sobre abortos, que ouviram falar sobre ele, que participaram ou não dos abortamentos, que entenderam o aborto como realidade e que conseguiram articular outros sentidos e significados em torno à prática. As orienta o fato de fazer o que acham melhor para si e possibilitar a outras que o façam acontecer, compondo redes de cuidado. Dessa forma, consideramos importante pensar em uma produção de subjetividades aborteiras. 
A definição provisória mais englobante que eu proporia da subjetividade é: "o conjunto das condições que torna possível que instâncias individuais e/ou coletivas estejam em posição de emergir como território existencial auto referencial, em adjacência ou em relação de delimitação com uma alteridade ela mesma subjetiva". Assim, em certos contextos sociais e semiológicos, a subjetividade se individua: uma pessoa, tida como responsável por si mesma, se posiciona em meio a relações de alteridade regidas por usos familiares, costumes locais, leis jurídicas .... Em outras condições, a subjetividade se faz coletiva, o que não significa que ela se torne por isso exclusivamente social. Com efeito, o termo "coletivo" deve ser entendido aqui no sentido de uma multiplicidade que se desenvolve para além do indivíduo, junto ao socius, assim como aquém da pessoa, junto a intensidades pré-verbais, derivando de uma lógica dos afetos mais do que de uma lógica de conjuntos bem circunscritos (GUATTARI, 1992, p. 12-13, destaque do autor).

O autor afirma uma concepção de subjetividade como um processo político e coletivo que se compõe por diversos vetores que vão além de uma instância psicológica e além das lógicas da representação. No texto Micropolítica: cartografias do desejo, sustenta que "a subjetividade não é passível de totalização ou de centralização do indivíduo" (GUATTARI; ROLNIK, 1999, p. 31). Os processos de subjetivação realizam-se, portanto, nas relações que estabelecemos conosco e com o mundo, nos modos de existir nos fluxos contínuos de imagens, afetos, sons, sensações e formas de consumir que são fabricadas na trama social. Assim, o corpo aborteiro perde a dimensão representativa e intensifica a capacidade de produzir novas conexões e agenciamentos sem-fim nas redes de acompanhamento, de afeto, de compartilhamento. Pensamos que, dessa maneira, é possível a produção de um "si", um modo de existir no coletivo, um estilo de existência a partir da multiplicidade das diferentes vivências com a prática. "Os processos de subjetivação [...]não são centrados em agentes individuais (no funcionamento de instâncias psíquicas, egóicas, microssociais), nem em agentes grupais. Esses processos são duplamente descentrados" (GUATTARI; ROLNIK, 1999, p. 31).

As aborteiras, por meio de práticas específicas, co-constroem outros sentidos, oferecem outras imagens, outras perspectivas que resistem às fabricadas pelas opiniões pessoais e crenças particulares. Elas intervêm nos processos e propõem significações alternativas sobre a prática do aborto, se 
organizam e relacionam-se com as instituições e a sociedade. Na criação das redes de solidariedade, as aborteiras colocam-se na ação e nessas práticas produzem outras possibilidades, questionando, assim, as normas e suas estruturas. Quando as aborteiras agem, possibilitam a pergunta sobre: $O$ que pode um corpo?

Muitas vezes, a palavra aborteira é utilizada de modo negativo, precisamente porque o abortamento é sobrecarregado de significados e imagens produzidas pela proibição e relacionadas ao crime; e porque as pessoas que se encarregam de fazer acontecer aquela prática, são condenadas socialmente, sendo nomeadas bruxas, assassinas, monstras, loucas, más. Essas acusações de bruxarias contra quem tem saberes populares, são produtoras de caças e perseguições que acontecem há séculos. Um exemplo disso é a chamada "caça às bruxas" da inquisição.

La inquisición condena a los cultivadores, recolectores, y conocedores de preparaciones a base de plantas, considerándolos brujas, alquimistas y parteras como herejes o desviantes satánicos: se inicia así un proceso de expropiación de saberes populares, de criminalización de prácticas de "intoxicación voluntaria” y de privatización de germoplasmas vegetales que culminará en la modernidad con la persecución del cultivo, e1 uso y el tráfico de drogas, la progresiva transformación de los recursos naturales en patentes farmacológicas y la confiscación de todo saber autoexperimental de administración de sustancias por las instituciones jurídico- médicas (PRECIADO, 2008, p. 112).

Na companhia de Preciado (2008), chegamos ao encontro da escritora "bruxa" (como ela se denomina) Starhawk, que, na sua obra Femmes, magie et politique (2003), compreende a perseguição das bruxas como parte de um processo de extermínio de saberes populares para a consolidação de um monopólio de saberes expertos que servem a interesses do capitalismo. Nesse sentido, a inquisição condena os saberes do prazer, as artes eróticas, impondo intercambio sexual reprodutivo e punindo a masturbação, sendo alvo de destruição saberes da comunidade, do imaginário popular, de feitiços e de magias. "Los poderes de las brujas, utilizados para hacer el mal o para 
curar, eran considerados como demoníacos porque emanaban de una fuerza no instituída" (STARHAWK, 2003, p. 273-274 apud PRECIADO, 2008, p. 116 37 ).

As aborteiras pertencem a uma força não instituída e possuem saberes bruxos que nem sempre são revelados. A historiadora italiana Silvia Federici, na sua obra Calibã e a Bruxa (2017) ${ }^{38}$, explicita que a partir da expansão do sistema capitalista, as pessoas foram progressivamente afastadas das suas vidas em comunidade e de suas terras. Que as mulheres, além de possuir conhecimentos curandeiros sobre ervas naturais e ciclos da terra, eram elas mesmas as que lavravam, adubavam e acessavam a natureza, acompanhando seus ritmos e, com ela, a autonomia sobre seus corpos, decidindo elas mesmas sobre a gravidez ou o aborto. Assim, os processos de reprodução acompanhavam a produção (FEDERICI, 2017).

Segundo Preciado (2008), essas mulheres que utilizam saberes tradicionais de saúde autogestivos de cura do corpo, baseados no uso de ervas e rituais, representam uma ameaça para os saberes expertos ou científicos, os especialistas, os autorizados. Desse modo, criam-se licenças para o exercício da profissão médica que não contemplam os saberes medicinais de mulheres, parteiras, bruxas. A "caça às bruxas" configura-se como mais um modo de arrebatar das mulheres toda autonomia que lhes pertencia.

As bruxas, identificadas como aquelas que serviam aos diabos, eram aquelas irreverentes, que possuíam uma sabedoria independente, uma potência demoníaca. Federici (2017) conta como ocorre progressivamente uma separação da produção e da reprodução, sobrando para as mulheres o trabalho reprodutivo que não é entendido como um trabalho neste sistema, senão que foi produzido como algo natural e biologicamente programado para elas. A "caça às bruxas" é um mecanismo que podemos compreender como atual na perseguição e catequização de povos originários, processos de escravidão, feminicídios, transfeminicídios, extermínio da população negra e grupos LGBT (FEDERICI, 2017).

\footnotetext{
${ }^{37}$ Tradução nossa: "Os poderes das bruxas, usados para fazer o mal ou para curar, eram considerados demoníacos porque emanavam de uma força não instituída"

${ }^{38}$ Recentemente publicada em português pelo Coletivo Sycorax em parceria com a Fundação Rosa Luxemburgo, de São Paulo. Site da fundação Rosa Luxemburgo disponível em: < http://rosaluxspba. org/>. Acesso em outubro de 2017.
} 
Nesse ponto, pensamos na 'caça das bruxas' (re)atualizada que vai adquirindo outros formatos, mas segue dirigindo-se àquelas irreverentes que, com suas potências demoníacas, representam uma ameaça para a lei dominante. Federici (2017) já nos disse que a subjugação das mulheres foi essencial para o sucesso da instalação do capitalismo e que esse é um mecanismo que não pertence ao passado. Constatamos isso na perseguição, tortura e até morte de quem habita o mundo se diferenciando e contestando aquelas normas que "se fazem e nos fazem, mas também nos desfazem" (OLIVEIRA, 2017, s/p). Só para citar um exemplo dessa perseguição: no mês de novembro do ano 2017, a filósofa Judith Butler visita Brasil novamente ${ }^{39}$. Muitas de nós ficamos felizes com sua visita e dissemos "nós" porque pertencemos àquele "conjunto indeterminado de ativistas, militantes, acadêmicxs, estudantes, pessoas de várias esferas, mas que partilham um olhar, com várias nuances e várias diferenças, mas que implica uma vontade de aprofundar as democracias e extendê-las" (OLIVEIRA, 2017, s/p). Judith Butler é uma das pensadoras que orienta esta escrita, para muitas de nós na academia, uma prestigiosa companhia para (re)pensar o que fazer com as normas que nos (des)fazem.

Mas infelizmente, a partir da visita de Judith Butler em São Paulo, começou a se gestar um movimento de pessoas que intentaram impedir a fala da filósofa. Começando por uma petição online, tentaram impedir a participação dela no seminário nomeado Os fins da democracia (que ocorreu no Sesc Pompeia, região central de São Paulo, entre 7 e 9 de novembro de 2017), sob o pretexto de que Butler seria promotora da ideologia de gênero, bandeira levantada por grupos de extrema direita agenciados em fundamentalismos religiosos direcionados ao extermínio de mulheres e LGBTs. "A proposta da petição é o silêncio do binarismo, o silêncio misógino, racista, heterossexista, transfóbico de quem pretende interromper as vozes outras, como encerrar exposições, proibir e queimar livros, destruir terreiros de candomblé e impedir outrxs de viver" (OLIVEIRA, 2017, s/p).

Durante o evento houve manifestação, o mais assustador foi que algumas dezenas de pessoas gritavam "Queimem a bruxa!" e "Queima no inferno, bruxa! Jesus tem poder!" enquanto faziam rituais portando crucifixos e ateando fogo numa boneca com uma foto do rosto de Judith

${ }^{39}$ A filósofa já havia atendido a outros eventos pelo país em 2015. 
Butler, relembrando os tempos sombrios da Inquisição. A filósofa, a respeito, escreveu:

Talvez aqueles que queimaram uma efígie minha como bruxa e defensora dos trans não sabiam que aquelas que eram chamadas de bruxas e queimadas vivas eram mulheres cujas crenças não se enquadravam nos dogmas aceitos pela Igreja Católica. Ao longo da história, atribuíram-se às bruxas poderes que elas jamais poderiam, de fato, ter; elas viraram bodes expiatórios cuja morte deveria, supostamente, purificar a comunidade da corrupção moral e sexual. Considerava-se que essas mulheres tinham cometido heresia, que adoravam o diabo e tinham trazido o mal à comunidade [...]. O fantasma dessas mulheres como o demônio ou seus representantes encontra, hoje, eco na "diabólica" ideologia de gênero. $E$, no entanto, a tortura e o assassinato dessas mulheres por séculos como bruxas representaram um esforço para reprimir vozes dissidentes, aquelas que questionavam certos dogmas da religião. [...] Afinal, queimar bruxas era uma forma de feminicídio executado em nome de uma moralidade e ortodoxia. Embora eu não seja estudiosa do cristianismo, entendo que uma de suas grandes contribuições tenha sido a doutrina do amor e do apreço pela preciosidade da vida - muito longe do veneno da caça às bruxas (BUTLER, 2017, s/p).

Judith Butler (2017) elabora com afeto e elegância uma escrita em resposta aos ataques produzidos em sua visita e nos convida para pensar na necessidade do contínuo exercício de diálogo, que forma parte de um éthos, na hora de pensar em democracia. Democracia que não existiria pelo consenso senão pela divergência, pela polifonia de vozes e pela acolhida das diferenças. Como chamar democracia se são impedidas de falar algumas (re)existências em detrimento de outras?

Butler (2017) chama nossa atenção sobre essa abertura ética como garantia de uma política de aspirações democráticas que se compromete em combater práticas discriminatórias, contra os assédios, contra as violências e os assassinatos das pessoas que habitam o mundo de diversas formas nas suas diferenças: "Essa abertura ética é importante para uma democracia que inclua a liberdade de expressão de gênero como uma das liberdades democráticas fundamentais, que enxergue a igualdade das mulheres como peça essencial de um compromisso democrático [...]" (BUTLER, 2017, s/p).

Perguntamo-nos: como falar em "democracia" quando se fala de "defesa da vida" e não se pensa na vida do corpo que engravida e aborta? 
Que democracia é essa que se limita ao triunfo da maioria, por exemplo, no voto de uma Proposta de Ementa Constitucional que proíbe o aborto até mesmo em caso de estupro $?^{40}$ Então, que democracia é essa? A pergunta não é: quando um óvulo fertilizado por um espermatozóide passa a ser considerado vida. A pergunta deveria ser: quando a pessoa que engravida deixa de ser "uma vida" e passa a ser uma incubadora regulada pelo estado e pelas suas instituições. São essas instituições que se apropriam dos corpos e respondem a mecanismos que funcionam produzindo morte, negligenciando o direito à autodeterminação sobre o aborto, determinando quais vidas não são dignas de serem vividas e pelo tanto, deixadas à morte. O que nos resta?

Pensamos assim nos saberes bruxos, nas alquimias, nas resistências, nas vidas não capturadas nas lógicas do Estado, nas aborteiras, nas redes, nos feminismos. Assim, recuperamos algumas dessas marcas, damos outros sentidos para elas e as misturamos com as marcas dos corpos que atravessam a experiência do abortamento em si: as senhoras de $\mathrm{Si}$, as clandestinas, suas narrativas. Corpos juntos e misturados em uma cumplicidade clandestina e desobediente que aborta leis, produtos, ordens, sangue parado, instituições, células. Corpos que sangram e pulsam conspirando juntos.

Há uma velha que mora numa toca da alma e que poucas têm visto. Outras conhecem. Monstra. Animal. Besta. Bruxa. Mais velha que o tempo, vive no presente e no passado. Ela possui um conhecimento de quatro patas. Animal. Um conhecimento que nos ensinam a nos envergonhar dele. Aquele conhecimento sujo. Selvagem. Conhecimento que contém enorme caudal de ideias, imagens, particularidades. A velha monstra, a besta que sabe. Ela sabe. Sabe das essências que habitam na natureza. É a arquivadora dos desejos das fêmeas. Tem o perspicaz olhar de uma velha bruxa e seu bigode percebe possiveis futuros. Essa velha selvagem, a que sabe,

\footnotetext{
${ }^{40}$ A Proposta de Emenda Constitucional (PEC) 181/2015 foi aprovada no dia 8 de novembro de 2017 por uma Comissão Especial da Câmara de Deputados Federais do Brasil. O objetivo original da PEC previa alterar o inciso XVIII do art. $7^{\circ}$ da Constituição Federal, que dispõe sobre a licençamaternidade em caso de parto prematuro. Esse texto foi modificado e a nova proposta altera a Constituição Federal para incluir o direito à vida desde a concepção. Se for aprovada em plenário, não será mais garantido o direito de aborto nos casos já previstos por lei: estupro, risco de morte e anencefalia fetal. Dos 19 deputados presentes na comissão referida, apenas uma deputada votou contra. A única mulher ali presente.
} 
a bruxa, está dentro de nós. Nos habita. Nos compõe. Ela mora no mais profundo da nossa alma e sussurra através da intuição cada vez que o anseio do profano nos acossa. Ela mora no entre o racional e o mito. Ela está conosco. Descobrimos marcas dela nas poesias, nos contos, na literatura, nos cantos, nas pinturas... ela nos devolve a intuição que foi secularmente saqueada, roubada. - Numa época onde esses dias eram os "dias da vergonha", não sangrar me trouxe certa alegria, não sabia o que estava acontecendo, mas eu não estava preocupada. Tinha 14 anos, mas eu era uma menina, não entendia, ninguém me explicou nada, naquela época isso era um grande segredo, uma grande vergonha tudo..., mas uma tarde soube... soube o que estava se passando no meu corpo.... Assim como desconhecemos muita coisa, temos muitos segredos...- Ela sorri com o olhar fixado naquelas imagens, naquela cumplicidade com outras, mas com ela própria num momento que parecia muito longe no tempo, mas recente nas marcas. As bruxas curam de jeitos inexplicáveis, elas conhecem daquelas ervas, daqueles chás que são fortes como elas, não são ervas mequetrefes, não. Hoje têm medicamentos e outras alternativas, mas também têm as ervas. As bruxas são sábias. Elas não precisam de médicos, nem clínicas. - Eu conheci aquela bruxa que me curou de maneira misteriosa. Todo mundo odiava ela na roça, no povoado. Mas todo mundo precisava dela -. Primeira vez que contava sua história: - porque você é a amiga da minha neta e me sinto melhor contando hoje. Velha, não tenho medo. Até porque eu também sei-. E esboça novamente aquele sorriso (BARONE, 2018)

Ficção de bestas que sabem, uivam, gargalham, cantam. Com elas, tentamos compreender alguns saberes populares sobre o corpo que vão se transmitindo na oralidade e que se afastam dos saberes institucionalizados. Para o saber médico, "aqueles dias da vergonha", ou seja, os dias que os corpos menstruam, os ciclos naturais são obrigados a se adaptar a outros ritmos e processos artificiais. Tal é o exemplo da tecnoregla, definida por Preciado (2008), que expõe a capacidade da pílula contraceptiva de reproduzir tecnicamente os ritmos dos ciclos menstruais naturais, quer dizer, produzir um sangramento tecnicamente induzido que produz uma ilusão de naturalidade do ciclo. $\mathrm{O}$ autor refere-se ao grande investimento na pesquisa científica sobre sexo e sexualidade no período da guerra fria, nos Estados Unidos, e explicita que assistimos uma mutação do capitalismo, que não só se caracterizaria pela transformação do sexo em objeto de gestão política 
da vida (na concepção biopolítica de Foucault), senão que essa gestão será levada a cabo através das novas dinâmicas do tecnocapitalismo avançado (PRECIADO, 2008).

O autor prossegue e nos convida a pensar na produção de uma "era farmacopornográfica" e, ao mesmo tempo, numa "bruxaria narcóticosexual". O farmacopoder, é aquele que, através de métodos técnicos específicos, incorporamos, cria metáforas tecno-vivas que podem ser tragadas, digeridas, assimiladas, auto administradas, in-corporadas. Possui a capacidade de imitar ciclos e processos naturais do corpo, integrando-o a instituições mais amplas e em lógicas mais complexas (PRECIADO, 2008). Esse conceito de farmacopoder nos permite pensar como o sexo se converteu no centro da atividade política e econômica atual pelos poderes da indústria farmacoquímica.

Seguindo o autor, pensamos na produção e circulação de imagens sobre o aborto. A produção de imagens dos fetos mortos, dos embriões falantes, dos zigotos pedindo para não serem abortados, dos fetinhos de plástico da campanha anti-abortista "el bebito" ${ }^{41}$, mostram a obscenidade que Preciado (2008) vai nomear como produção pornográfica. A pornografia é um dispositivo que, através da produção de imagens, permite estimular mecanismos que se fazem corpo. O farmacopornopoder é um efeito do tramado das representações discursivas e visuais que são produzidas pelos dispositivos institucionais como a família, a escola, as legislações, a mídia, as religiões. A pornografia, segue Preciado (2008), é mais que a questão da imagem e o seu conteúdo, a cenografia, a teatralização com que a imagem vai ser exposta. É todo um sistema de signos, de códigos, textos e imagens politicamente regulado. "El sujeto es al mismo tiempo un productor y un

\footnotetext{
${ }^{41}$ Campaña impulsada por Mariana Rodríguez Varela, filha de Alberto Rodríguez Varela, quem foi ministro de Justicia durante a ditadura militar na Argentina e advogado defensor do genocida Jorge Videla na causa de roubos de bebês. A campanha anti-abortista "El Bebito" se opõe ao direito ao aborto em qualquer circunstância, incluso nas excepções de aborto legal já estipuladas no Código Penal. A campanha anti-abortista utiliza bonecos de plástico com forma de embrião que são distribuídos com cartazes cuja legenda diz "tengo 8 semanas, estoy creciendo, quiero nacer". Mais informações disponíveis em: <https://www.laizquierdadiario.com/El-Bebito-la- increible-campanade-la-hija-de-un-funcionario-de-la-dictadura-y-defensor-de-Videla>. Acesso em março de 2018.
} 
intérprete de signos, siempre implicado en un proceso corporal de significación, representación y autorepresentación" (PRECIADO, 2008, p. 8342).

A produção de imagens sobre o aborto é uma das técnicas que pretende deslegitimar os corpos que abortam, des-subjetivá-los e reduzi-los à categoria de criminosos. Dessa forma, pode-se fazer uso da força de trabalho reprodutivo dos corpos engravidantes de forma gratuita, produzindo corpos destinados a serem potenciais procriadores e sujeitos sempre a vigilância e controle (PRECIADO, 2008).

O que nos interessa é a produção de imagens que, além das produzidas pelo sistema farmacopornográfico, constituem-se "contra-imagens" na arte, na literatura, na transformação da linguagem. Tentamos compreender, assim, outros contextos que apresentam outras concepções de corpo, gestações, sangramento, aborto, de maneira diferente das concepções chamadas científicas. Aqui, não pretendemos discutir a eficácia dos chás e substâncias dos saberes das bruxas para provocar um aborto, mas consideramos importante trazer aquelas narrativas que falam da prática do aborto em contextos onde são outros os saberes e as práticas para fazer o que elas consideram melhor para si. Paloma del Cerro (2011), nos canta:

Me darán las plantas todos sus aromas, sus colores Renacer y sembrar vida cuando los cuerpos transpiran

¡Ay! curandera curando, curandera, curando

Si parimos con placer si nos amamos sin dolores Nos sanamos con amarnos al mirarnos en el alma

¡Ay! curandera curando, curandera, curando

Ya puedo sentir el poder natural de tu calor, desde el interior yo me estoy abriendo

Quiero que toda la potencia de mi madre tierra me pegue fuerte, me pegue adentro

Curame para que te de vida siempre, vamos rompiendo la cadena de la mente

La pachamama lo siente, dale hasta abajo curandera presente Tengo el canal abierto, estoy ardiente, tengo la sangre que me hierve bien caliente.

(DEL CERRO, 2011).

${ }^{42}$ Tradução nossa: "O sujeito é ao mesmo tempo produtor e intérprete de signos, sempre envolvido em um processo corporal de significação, representação e autorrepresentação." 
Entre saberes não legitimados, feitiços e problemas, entendemos que a perseguição às bruxas, assim como às aborteiras, pode ser uma batalha entre saberes profissionalizantes ou especialistas contra saberes populares ou pagãos e, assim,

se trata de exterminar o confiscar una cierta ecología del cuerpo y del alma (...) de erradicar las formas de subjetivación que se producen a través de experiência colectiva y corporal de rituales, asimilación de sustancias y de autoexperimentación (...) con su propia sexualidad (PRECIADO, 2008, p. $\left.117^{43}\right)$.

Isto parece funcionar como instância de controle e repressão dos saberes transmitidos pela experiência das parteiras, aborteiras, mulheres, bruxas, na clandestinidade para contribuir no monopólio de um saber especializado, com licença médica para intervir nos corpos dos outros, das outras.

Consideramos importante aos efeitos do nosso trabalho mergulhar em outras realidades, nos encontros bruxos em outros topos, e habilitar uma escuta do que contam as que contam. Co-construimos narrativas numa (re) apropriação criativa, inventiva e interventiva daquilo que nos afeta com as bruxas para resgatar experiências daqueles saberes, dos conhecimentos ancestrais que muitas vezes são deslegitimados, ignorados, subvalorizados por serem considerados menos científicos e, por tanto, menos eficazes e até perigosos. Aquela sabedoria que tentamos recuperar nas narrativas é usurpada secularmente pela chamada ciência, pelo farmacopoder (PRECIADO, 2008) que nos expropria daqueles saberes para logo nos serem vendidos em outros formatos, de cartela e bula, por exemplo.

Entendemos que esses saberes co-existem, re-existem, resistem, escapam de algumas lógicas instituídas e de algumas lógicas capitais. Essas práticas abortivas carregam o tempo da ancestralidade e, reconhecendo nossas limitações de acesso, nos detemos a escutar. Esses não são conhecimentos revelados em receitas de bula. São saberes que dialogam com os elementos da mãe terra e que adquirem legitimidade nas práticas com amargos chás que não precisam dos laboratórios que vendem as pílulas para abortar.

\footnotetext{
${ }^{43}$ Tradução nossa: "se trata de exterminar o confiscar una cierta ecología del cuerpo y del alma (...) de erradicar las formas de subjetivación que se producen a través de experiência colectiva y corporal de rituales, asimilación de sustancias y de autoexperimentación (...) con su propia sexualidad”
} 
Ainda que as bocas falem diversas línguas, os contos viajam de boca em boca. - Mas não só falam as bocas, as almas também dialogam -, disse ela. De boca em boca. De língua em língua. De alma em alma. Mitos. Lendas. Contos. Cantos. Relatos. Fábulas. Vida. Ela vem da zona andina da América do Sul, entre os "wankas" e os "chankas" do Perú. É mais poesia do que mulher. Uma criatura viva que, além de humana, está feita de coisas bonitas, húmidas, ardentes, mágicas. Sua casa ("wasi") cheira a milho doce. Cheiro que se mistura com o aroma de fumaça da madeira e a erva fresca. Na comunidade, a brisa húmida traz o perfume da terra molhada enquanto os cantos de diversas espécies de pássaros se fazem ouvir ininterruptamente. Oferece uma bebida. Sabores do originário que despertam o vivo. Cântaros de "chicha de jora" e contagiosa alegria de cantos-contos que chegam através dela. Tambores, "zampiñas", "quenas", "charangos", "chacarpayas", gritos, cantos, aire, energia, magia. -O "quíchua" estava adormecido em mim. Eu podia senti-lo. Eram vozes ancestrais que me sussurravam cantos e contos desde que eu era criança -. Olhando para o passado que se fez presente nesse momento, canta: - Puñullay waway puñullay, Kikillay waway kikillay, sumaqri kunan kaniqa, Michiri kunan kaniqa -... Língua das ancestrais que dormia nela, até que soube que devia seguir o cheiro fresco da seiva quente dentro de si, para explorar o que tinha afundado no pó dos contos. Os contos que sua avó contava, foram aqueles incriveis tesouros que, junto com a sua intuição, despertaram os "quíchuas" e "aymarás". A partir dali, é mais uma guardiã dos seus próprios fogos criadores. Foi escarvando para descobrir séculos de terra, ossos essenciais, escavando nos estratos da cultura, seguindo o emaranhado das raízes.

Aprendeu o "chanca" com a sua avó, mas não só. - Quando percebi que sabia o "quíchua" sem saber que sabia, sem saber que minha avó tinha me ensinado desde "wawa", despertou-se em mim uma sacerdotisa. Sentia aos poucos que ia recobrando os meus próprios poderes. Fui conhecendo as que invocam o fogo, as que invocam céu, as que invocam água. Juntas, invocamos aos quatro elementos. Oferecemos cantos, danças, porque nossa "Pachamama" precisa de nós. Temos que entender que "Pachamama" não pode ser compreendida como sinónimo de mãe terra porque isso é reduzi-la à fertilidade, como nos reduzem às mulheres.

A "Pachamama" é um todo que vai além da natureza que podemos enxergar. Ela contém a vida. É energia que não nos pertence. Nós pertencemos a ela.

Para nomear órgãos ou vísceras do corpo, não se conhecem muitas vozes no seu povo..., mas as ervas, as seivas e os vegetais foram-Ihe sempre familiares. Com a sua avó, aprendeu também sobre o uso ancestral de alguns preparos que até os 
demônios gostavam de confeiçoar. Ela possui aquela sabedoria. Ela é "warmi janpiri". Antecessora das recebedoras, das parteiras, das curiosas, das conhecedoras. Ela sabe aonde achar e recolher a "huachanqa". Só ela. Ela e outras "yachachiq warmikuna". É assunto delas. Elas sabem daquele lugar escolhido pelas deusas onde achar a planta. $O$ preparo deve ser na entrada do sol, ao anoitecer, na mudança da lua. É do lado oposto à saída do sol que a "killamama", representada pela lua, se faz presente. É para ela que se oferece o rito para devolver à "pachamama" os favores recebidos. -Me conecto com minhas ancestrais, as "warmi timkuy". Sigo suas pegadas, levo suas marcas. Ponho meus dedos na terra nativa, procuro nas raízes que dão vida. Elas, flores feiras que são fertilizadas com nosso sangue para que cresçam fortes e sãs. São milhares de anos de colheitas que celebramos como presente da mãe terra. "Killamama" me observa e, com sabedoria milenar, me ilumina. Me guia- (BARONE, 2018).

Aprendemos com as bruxas, com as velhas e as sacerdotisas. Mas também convivemos com as crises que a tensão do pensamento produz e, nesse sentido, pensamos em nossos gritos de luta quando exigimos ao estado a legalização do aborto como forma de acessar à prática em segurança. Pensamos que é esse Estado também o que produz enquadramentos dizendo que algumas vidas não são dignas de serem vividas, por exemplo, as que vivem nas intersecções de classe, raça, etnia, orientação sexual, territórios nos quais habitam. Qual é nossa exigência? É pela via dos direitos? Direitos para quem? Direitos das vidas de quem? Muitas vidas resistem aos modos das bruxarias, das redes de amizade, com as ancestrais, com saberes populares, com alquimias que não estariam capturadas pelas lógicas capitais:

E abortar não se trata simplesmente do direito a fazê-lo. O certo é que não se trata do direito em si, nem de sua legalidade formal e superficial. Embora ao final das contas, tudo isso nos pesa no corpo, sobre o corpo, e ao mesmo tempo nos atravessa de maneira fatal. A Lei pesa sobre meu corpo. E ao mesmo tempo a quero sacar. O direito, essa frase que dizemos todo o tempo: "eu tenho direito a...", no melhor dos casos vem a legalizar o exercício de uma prática de liberdade. E no pior dos casos, o cremos. E cremos profundamente. Acreditar que temos "direito a...", para depois necessitar de alguém que o legitime e reconheça. E neste caminho, o direito já não o temos, ou melhor dizendo, já o tem outro. (LA NIÑX MONSTRUA, 2014, p. 9). 
La Niñx Monstrua (2014) prossegue com a ideia de que ninguém pode dar "direito à escolha" a ninguém, como tampouco pode tirar de alguém porque "a liberdade de escolher" antes que um direito, primeiro é um fato.

Porque a pergunta para mim é como fazer do aborto uma experiência vivível, digna, riquíssima, poderosa para quem a escolhemos; antes que fazer dela uma estatística, uma fatalidade de slogan político, uma rua sem saída. Mas isso não significa negar que, como toda experiência possui uma diversidade de nuances, de dobras, de voltas, de idas e vindas, de fugas. Possui tudo que uma experiência deve ter: é única (LANIÑX MONSTRUA, 2014, p. 6).

Interessante o que nos convida a pensar LaNiñx Monstrua (2014): pensar o aborto como uma experiência vivível e única nos permite a possibilidade de pensarmos como uma prática que, além de intensa, possa ser vivenciada como um "exercício da liberdade". Dessa forma, é uma experiência que possibilita recuperar um poder, aquele secularmente roubado, aquele poder bruxo de autodeterminação de uma experiência digna.

A partir da autora, entendemos como uma experiência que pode ser narrada, não para fazer dela uma estatística ou tratá-la como informação, senão como modo de ação, de negação do que nos é imposto: ação herética, experiência única que, seguindo com Larrosa (2015), requer outras ações. A experiência requer que nos detenhamos para (re)pensar, escutar, sentir, ir devagar; requer tempos e espaços outros, tempos que nem sempre estamos dispostas a criar e espaços que nem sempre são facilitados pelos ritmos desta sociedade dentro das lógicas capitalísticas. Experiência também é exercício de interromper as opiniões, os juízos e "cultivar a atenção e a delicadeza, abrir os olhos e os ouvidos, falar sobre o que nos acontece, aprender a lentidão, escutar aos outros, cultivar a arte do encontro, calar muito, ter paciência e dar-se tempo e espaço" (LARROSA, 2015, p. 24). Nesse exercício de nos deter que propõe o autor, permitimo-nos afetar em "uma experiência intensa, uma intensidade que nos atravessa de maneira total, filosa, desigual e milimétrica" (LANIÑX MONSTRUA, 2014, p. 3).

Pensar o aborto como exercício e prática de liberdade, requer reconhecer que não existe de um lado a escolha e de um outro a determinação pelas relações de poder, nem uma autonomia que é possível na individualidade, 
assim como, não estamos totalmente determinadas pelas forças da legalidade e a ilegalidade impostas pelo Estado. "A liberdade de escolher da qual falamos não tem a ver com a ideia de ser cidadãs: mães, brancas, lindas, ordenadas, respeitosas e boas esposas, não é o "direito ao voto", não está em nenhuma constituição, tampouco está na Lei” (LANIÑX MONSTRUA, 2014, p. 10). Estamos falando de experiência como um exercício de liberdade. Aquilo que é garantido pelas redes, pela criação de coletividade é, de fato, o que tem capacidade de transformar a si mesma e ao mundo.

Definindo experiência, Foucault (2006, p. 7) afirma que "é preciso transformar a experiência individual em saber coletivo. Quer dizer, em saber político". Nesse sentido, o exercício de liberdade, só pode se dar no encontro com a outra/o na coletivização dos afetos da experiência, no conto, no canto, na poesia, nas redes: "quando abortamos falamos por nós mesmas, e nisso consiste a liberdade" (LANIÑX MONSTRUA, 2014, p. 6). O convite se estende para pensar na hipocrisia que rege o debate sobre o aborto quando nos diz que vivemos uma "liberdade legalizada", é dizer que essa liberdade só existe nos termos formais. "É uma liberdade abortada, truncada, mediatizada, absurda, hipócrita. Por outro lado, acho que a liberdade de escolher é mais precisamente, uma ação" (LANIÑX MONSTRUA, 2014, p. 11).

Nesse sentido, Foucault (1994, p. 276) vai dizer que "a liberdade dos homens não é nunca assegurada pelas instituições e leis que têm por função garanti-la (...). Não porque elas são ambíguas, mas porque a 'liberdade' é o que se deve exercitar". Assim, a liberdade assumiria caraterística de vivência, de movimento, de experiência, de prática, de ação. "Abortar, em nossos próprios termos, é isso: uma ação antes que um direito. Ou, em todo caso, o direito vem depois: vem penalizar essa ação, submetê-la ao juízo-legal. E neste mecanismo devimos pura ilegalidade" (LANIÑX MONSTRUA, 2014, p. 11).

Entre feitiços e problemas, nós, as aborteiras, as monstras, as feias, as sujas, as bruxas, as loucas e/ou as más, não queremos dizer que as políticas públicas não são necessárias, mas sim, (re)pensar que políticas são essas e que corpos atingem, quais vidas tem acesso a essas políticas nomeadas universais? Butler (2016) nos fala sobre as vidas precárias, que alguns sujeitos não estão nas mesmas condições de humanidade que outros. Certas vidas não se qualificam como vidas, não são concebidas como tal de acordo com algumas construções discursivas. Butler (2018, p. 65) nos diz que "a precariedade é a rubrica que une as mulheres, os queer, as 
pessoas transgêneras, os pobres, aqueles com habilidades diferenciadas, os apátridas, mas também as minorias raciais e religiosas [...]". Com a autora, nos perguntamos: como fazer as políticas efetivamente públicas, e que seu caráter público seja pela produção de um comum que nos une a partir da precariedade?

As políticas públicas podem ser estratégicas e necessárias, porém não podem ser o único objetivo das aborteiras porque, sem uma crítica constante e, sobretudo, pensando nas multiplicidades dos corpos que abortam em suas singularidades. As políticas públicas universais podem ser injustas e gerar mais desigualdades, quando se observa a realidade das vidas e suas experiências. As políticas universais excluem! Segundo Akotirene (2020, p. 59-60):

[...] podemos identificar a exclusão racial por critério de gênero promovida pelo universalismo das políticas públicas relacionadas, o fato de mulheres e meninas negras estarem situadas em pelo menos dois grupos subordinados que, frequentemente, perseguem agendas contraditórias, dando a impressão de que todas as violências policiais dilatadas para o sistema penal são contra homens negros. Todas as violências domésticas dilatadas para o encarceramento feminino ou feminicídios são impostas as mulheres brancas

Um exemplo dessa dinâmica de universalismo excludente de uma política pública é a realidade do Uruguai, onde o aborto é legalizado. Lá, alguns movimentos estão contestando o modelo de consulta com prazo de reflexão de uma semana que a lei estabelece para a decisão antes de abortar e depois do abortamento. Nesse sentido, os encaminhamentos contraceptivos para esses corpos são questionados.

Nessa direção, denunciamos que a negligência com a qual o Estado e a sociedade tratam a temática do abordo, geram contextos que produzem e potencializam situações de morte, não de vida. Assim, não se trata apenas de reforçamos a ideia de que não necessariamente abortos clandestinos ou fora das leis sejam inseguros. Muitas aborteiras não são capturadas pela interferência do Estado e rejeitam ser incubadoras reguladas por esse. Alguns dizem "antigamente, quando as bruxas existiam..."; insistimos em que as bruxas nunca deixaram de existir. É ali que o risco de sermos simbolicamente jogadas na fogueira persiste e isso é feito de diversas formas. Resistimos 
em círculos ao redor de uma grande cozinha onde mágicos saberes, altas risadas, alegres feitiços podem proliferar e contagiar outros corpos porque esses conhecimentos são passados de mãe para filha, de avó para neta, de vizinha para vizinha, amiga para amiga e, essas narrativas nos importam, elas também se "presentificam" na história. 


\section{REFERÊNCIAS}

AKOTIRENE, Carla. Interseccionalidade. São Paulo: Sueli Carneiro; Editora Jandaíra, 2020.

BARONE, María Antonella. SENHORAS DE SI: Problematizando as incidências das biopolíticas nos corpos que sangram e co-produzindo narrativas que (re)inventam a vida a partir da prática do aborto. Dissertação (Mestrado em Psicologia Institucional). Universidade Federal do Espírito Santo. Vitória, 161 p. 2018.

BUTLER, Judith. Judith Butler escreve sobre sua teoria de gênero e o ataque sofrido no Brasil. Tradução Clara Allain. São Paulo: Revista on-line Folha Express, 19 de novembro de 2017. Disponível em: <http://www1.folha.uol.com.br/ilustrissima/2017/11/1936103-judithbutler-escreve-sobre-o-fantasma-do-genero-e-o-ataque-sofrido-no-brasil.shtml>. Acesso em: novembro de 2017.

BUTLER, Judith. Problemas de gênero: feminismo e subversão da identidade. Tradução Renato Aguiar. Rio de Janeiro: Civilização Brasileira, 2003.

BUTLER, Judith. Quadros de Guerra: Quando a vida é passível de luto? Editorial Civilização Brasileira. $2^{a}$ edição. Trad. de Sérgio Lamarão e Arnaldo Marques da Cunha. Rio de janeiro, 2016.

BUTLER, Judith. Corpos em aliança e a política das ruas: notas para uma teoria performativa deassembleia. Rio de Janeiro: Civilização Brasileira, 2018.

DE ABREU, Carla. Narrativas Digifeministas: Arte, Ativismo e Posicionamentos Políticos. Revista Brasileira de Pesquisa (Auto)Biográfica, Salvador, v. 02, n. 04, p. 134-152, jan./abr. 2017.

DEL CERRO, Paloma. Curandera. AWA Produções Audiovisuais. Buenos Aires, Argentina, 2011.Disponível em: https://www.youtube.com/watch?v=j4KHvziuVms.

DINIZ, Debora; MEDEIROS, Marcelo; MADEIRO, Alberto. Pesquisa Nacional de Aborto 2016. Ciênc. Saúde Coletiva [online], v. 22, n. 2, pp. 653-660, 2017. <http://dx.doi. org/10.1590/1413-81232017222.23812016>.

FEDERICI, Silvia. Calibã e a bruxa: mulheres, corpo e acumulação primitiva, 2004. Tradução do coletivo Sycorax. Editora Elefante: São Paulo, 2017.

FOUCAULT, Michel. À propos de la généalogie de l`éthique: un apercu du travail en cours. In: DITS ET ECRITS IV. Paris: Gallimard, 1994.

FOUCAULT, Michel. Estratégia, poder, saber. Organização e seleção de textos Manoel Barros da Motta. Trad. Vera Lucia Avellar Ribeiro. 2.ed. Rio de Janeiro: Forense Universitária, 2006.

GUATTARI, Félix. Caosmose: um novo paradigma estético. Trad. de Ana Lúcia de Oliveira e Lúcia Cláudia Leão. São Paulo: Ed. 34 (Coleção TRANS), 1992. 208 p.

GUATTARI, Félix; ROLNIK, Suely. Micropolítica: Cartografias do Desejo. Petrópolis: Vozes, 1999. 
LA NIÑX MONSTUA. Devir abortiva: escrituras desde o coropo, desde a raiva e nossas próprias experiências. Publicadas no fanzine POESIA.NOT.DEAD. Herética Edições Lesbofeministas Independentes, 2014.

LANIÑX MONSTRUA. Devir Abortiva: escrituras desde o corpo, desde a raiva e nossas próprias experiências. Heretica Ediçoes Lesbofeministas Independentes. Publicada no fanzine POESIA.NOT.DEAD, 2014.

LARROSA, Jorge. Tremores: escritos sobre experiências. Belo Horizonte: Autêntica, 2015.

OLIVEIRA, João Manuel. Pode Judith Butler Falar? Orgulhos Críticos do Sul. Publicado em 28 outubro, 2017. Disponível em: <https://orgulloscriticos.wordpress.com/2017/10/28/podejudith-butler-falar/>. Acesso em: novembro de 2017.

PRECIADO, Beatriz. Testo Yonqui. Madrid, Es: Editorial Espasa Calpe, S. A., 2008.

WACHAS, rádio. Wacha, Bruja y Abortera. @wachasradio. 8 de março de 2018, 18:30 hs. Buenos Aires, Argentina. Tweet. 


\title{
CORPOS EM TRANSFORMAÇÃO: NARRATIVAS DE MULHERES TRANS E TRAVESTIS SOBRE OS SENTIDOS DE ENVELHECER
}

\author{
Ana Paola de Souza Lima \\ Danie Marcelo de Jesus
}

O objetivo deste artigo é tratar da percepção de envelhecimento descrita em narrativas de mulheres trans e travestis. Apesar de contarmos com uma vasta bibliografia brasileira com a temática sobre transgeneridades ${ }^{44}$, observamos uma escassez de estudos nas áreas de Psicologia, Antropologia, Sociologia e igualmente em Linguística Aplicada que procurem entender a relação entre envelhecimento e esse grupo específico.

Assumimos uma vertente da Linguística Aplicada transgressora e crítica (MOITA LOPES, 2006), que se caracteriza por um fazer científico de caráter multi/inter/in-disciplinar, de modo a promover práticas transdisciplinares, levando em consideração o questionamento de fronteiras normativas relativas a gêneros, sexualidades, classes sociais e raças, bem como a problematizar crenças arraigadas sobre comunidades coesas e corporeidades idealizadas que ultrapassem espaços hegemonicamente estabelecidos discursivamente.

Advertimos aos nossos leitores que não falamos pelas mulheres trans e travestis que compõem as narrativas deste estudo, mas como pesquisadores

\footnotetext{
${ }^{44}$ Jesus (2012) considera que o termo transgênero ou trans engloba pessoas travestis, transexuais e intersexuais, pessoas que nasceram com um dado sexo lido historicamente como biológico, mas que não se identificam com o gênero que lhes foi atribuído. Em suma, a autora complementa que pessoas não cisgêneras são aquelas que não se identificam com o gênero que lhes foi atribuído no nascimento, sendo, portanto, autodenominadas transgêneras. Em oposição, Rodovalho (2017) também salienta que a biologia não pode apenas ser determinante do gênero, ou seja, a genitália também é um construto tanto quanto o gênero.
} 
cisgênero $\mathrm{s}^{45}$ culturalmente sensíveis às diferenças e cientes dos privilégios que possuímos na sociedade em que vivemos. Também gostaríamos de enfatizar que a própria categoria cisgeneridade abarca sujeitos e sujeitas que se pressupõe não precisarem ser categorizados e/ou definidos, por enquadrarem-se em uma classe de pessoas "normais", "não-abjetas". Portanto, a condição de ser cisgênero é tão normatizada discursivamente em nossas práticas sociais que não pensamos em nos categorizar como tal.

Logo, sujeitos(as) cisgêneros(as) leem seus corpos como corpos normais, naturais, legítimos, os quais não precisam ser interpretados. Acreditam, então, ser corretos e, por isso, acabam aplicando seus saberes e verdades, sem consultar as pessoas trans ou transgêneras sobre se o que dizem sobre elas é realmente o que ocorre com seus corpos, ou seja, suprimem o direito de autodeterminação de gênero que as pessoas trans/transgêneras tanto almejam.

Diante desse quadro, podemos afirmar que as pessoas cisgêneras, que se dizem totalmente confortáveis com seus sexos biológicos e denominações de gênero, de um modo geral, acabam submetendo pessoas autodenominadas transgêneras a uma colonização no que diz respeito aos seus papéis de gênero, como se os corpos transgêneros fossem uma cópia, uma releitura de corpos cisgêneros, conforme pontuam os discursos médico, psiquiátrico, jurídico e social. Ainda para pessoas cisgêneras, os corpos trans precisam encontrar-se dentro de certa passabilidade ${ }^{46}$ para que sejam aceitos, construídos em conformidade com os moldes e contornos dos corpos da matriz cisgênera.

Feitas nossas advertências e retomando nosso tema, Antunes (2010) sustenta que as mulheres trans e travestis são consideradas velhas se não conseguem desempenhar o trabalho como profissionais do sexo. Nesse sentido, essas mulheres são marcadas por inúmeras formas de violência,

\footnotetext{
${ }^{45}$ De maneira extremamente reducionista, pessoas cisgêneras são aquelas que se encontram em condições de aceitabilidade com o seu sexo biológico e com o gênero com o qual foram designadas em seus nascimentos. Para as pessoas cisgêneras, a biologia é responsável pela atribuição dos gêneros, fator que é legitimado pelos discursos psico-bio-médico, jurídico e social.

${ }^{46} \mathrm{O}$ termo passabilidade é por vezes usado para referir-se ao quanto um homem ou uma mulher trans se passam por um homem ou mulher cis, ou seja, é quando a pessoa trans é lida socialmente como uma pessoa cis, de maneira a invisibilizar a transgeneridade. Embora o termo passabilidade ainda seja muito utilizado, ele vem sendo substituído pela expressão "leitura social".
} 
oprimindo-as e as agredindo de modo a ser um aspecto, talvez determinante, para o seu envelhecimento precoce.

Casteleira (2013) também confirma que uma pessoa trans envelhece antes que uma pessoa cisgêneras, principalmente em virtude do uso excessivo de hormônios, silicone e, principalmente, por causa das violências a que são expostas no trabalho enquanto profissionais do sexo, profissão geralmente recorrente. Para ele, uma travesti aos 40 anos pode ser comparada a uma mulher cisgênera aos 60 anos. Já para Siqueira (2004), "travestis" e "velhice" constituem duas categorias altamente excludentes, pois aquelas que ultrapassam os cinquenta anos enfrentam um duplo processo de marginalização e muitas encaram condições precárias de sobrevivência.

Considerando o exposto, o corpus desta investigação conta com os enunciados reproduzidos pelas travestis/mulheres trans, obtidos de suas narrativas por meio de entrevistas. Convém lembrar que, na perspectiva teórica adotada neste trabalho, enunciados consistem em um conjunto de regras que ditam os limites e as maneiras como algo é expresso, só definíveis em sua individualidade no interior de um sistema linguístico, definidos em conformidade com uma determinada época ou sociedade (FOUCAULT, 2008).

Por fim, esta introdução tem por objetivo apresentar brevemente o tema de nossa pesquisa. A análise se baseia na relação entre discurso e envelhecimento exposta nas narrativas de mulheres trans e travestis com a finalidade entender os sentidos que elas dão ao processo de envelhecimento. Para esquadrinhar nosso corpus, buscaram-se parâmetros analíticos e metodológicos nos estudos sobre discurso e alguns princípios sobre envelhecimento, com a finalidade de entender os sentidos desse fenômeno para nossas participantes. Ao concluir, procuramos refletir sobre a importância da pesquisa sobre discurso, transgeneridades e envelhecimento, bem assim sobre suas consequências políticas, culturais e sociais no âmbito dos estudos relativos à linguagem.

\section{Envelhecimento, corpo, discurso e poder}

Santos (2010) aponta que a diminuição do poder físico em decorrência do envelhecimento acarreta a queda da produtividade dos(as) indivíduos(as), o que pode diminuir o poder aquisitivo e alterar a posição social ocupada por aqueles(as) indivíduos(as), em sociedades capitalistas. A sociedade, de 
um modo geral, tende a enxergar a velhice como um período de dificuldades físicas, biológicas e de baixa produção econômica, além de representar um período de descrédito para tais sujeitos(as).

Já para Antunes (2010), a velhice consiste em uma série de enunciados que estabelecem a maneira como este segmento da população deve se comportar, nos levando a crer que os discursos médico, estético e midiático, em geral, impõem discursivamente práticas sociais de como as pessoas devem viver. Assim, o processo de envelhecimento pode variar de acordo com a cultura, o local e a época em questão (SANTOS et al., 2014; ANTUNES, 2010).

A esse respeito, podemos inferir que os comportamentos ordenados para a população idosa vêm sofrendo uma remodelagem, de modo a impor-lhes um comportamento semelhante ao dos(as) jovens (ANTUNES, 2010). A sociedade de controle ${ }^{47}$ (FOUCAULT, 2008) compele uma dita "qualidade de vida" que "impede" que os(as) indivíduos(as) envelheçam, dizimando os estigmas de doença e decadência tão comuns na descrição dessa população (ANTUNES, 2010). Soma-se a tal fato o aparecimento de inúmeras instruções acerca do que consiste "envelhecer com dignidade", em contraposição ao descaso na criação de políticas públicas cidadãs e que sejam especificamente voltadas para as diferenças.

Um elemento, contudo, que parece ser predominante nos trabalhos científicos sobre envelhecimento, segundo Santos e Carmo (2013), é o pressuposto de uma heterossexualidade. Daí o número expressivo de pesquisas que falam da velhice de homens e mulheres como sendo, via de regra, todos(as) sujeitos(as) heterossexuais, inscrevendo os(as) idosos(as) na moral heterossexual (MOTA, 2009).

Em outras palavras, o mundo heteronormativo dita as regras sociais de modo a supervalorizar a altivez e um determinado parâmetro de beleza corporal com bases na representação jovem (MOTA, 2009). Daí a compreensão de onde surgem os discursos controlados pelo biopoder e

\footnotetext{
${ }^{47}$ A sociedade de controle consiste em um modelo de gestão social "invisível" que tem suas raízes na sociedade disciplinar, em que os sujeitos sociais não mais sofrem a violência física como forma de punição por não enquadramento aos estilos de vida, porém, observa-se um controle ideológico e vigia de corpos pelos meios de comunicação de massa e por todos os indivíduos desta mesma sociedade (FOUCAULT, 2008). A menção à sociedade de controle ocorreu aqui de modo a reforçar a ideia da necessidade da adequação dos indivíduos a essa norma de uma vida jovial, longe das mazelas da velhice, sob pena de vigia e controle dos demais indivíduos da sociedade.
} 
pela biopolítica (FOUCAULT; 2008; 2007; 1987), os quais impõem a busca por uma vida mais saudável, alimentação natural e que propicia a longevidade, uso de cosméticos - ao corpo dos(as) idosos(as) é dada a busca da saúde e prazer infinitos (MARQUES, 2004).

Em relação ao envelhecimento de pessoas trans e travestis, as participantes da pesquisa de Siqueira (2004) alegam ter satisfação em viver a velhice e, concomitantemente, apontam as dificuldades por elas enfrentadas nesse período. Suas participantes enxergam o fato de chegarem à velhice como um status social, tendo escapado da AIDS, dos vícios e podendo transitar e serem respeitadas por diferentes segmentos sociais.

Interessante observar que no decorrer da nossa pesquisa também constatamos tal satisfação acerca da velhice identificada por Siqueira (2004). Nossas participantes se posicionam da mesma maneira que as travestis da pesquisa de Siqueira (2004), principalmente no tocante à sobrevivência nas ruas e drible na AIDS. A mesma pesquisadora também percebeu que as travestis tendem a se voltar mais para a esfera da casa para usufruírem de uma velhice mais tranquila, participando mais efetivamente de atividades políticas e de militância e socializando-se com familiares e amigos (SIQUEIRA, 2004). No que diz respeito à sexualidade, Siqueira (2004) constatou que ainda se encontram ativas, mesmo que as relações sexuais ocorram com frequência menor. Tal fato também se confirma por meio das nossas participantes, as quais alegam que a chegada da velhice não representa a diminuição de seu apetite sexual.

A pesquisa de Antunes (2010) almejou investigar o impacto das normas de gênero sobre as travestis que chegaram à velhice. Para o autor, a terceira idade representa um referencial relevante, um exemplo a ser seguido e também um alerta para as mulheres trans e travestis mais jovens. São consideradas velhas no momento em que seus corpos não mais podem ser vinculados à prostituição, embora nem todas tenham uma ocupação/ profissão paralela que as livre de doenças e violências (ANTUNES, 2010).

Esse é outro fato mencionado pelas nossas participantes. Elas alegam que, depois de certa idade, aquelas que se encontram envolvidas na prostituição não conseguem mais o número de clientes que possuíam antes. As participantes mais velhas de nossa pesquisa, e que ainda trabalham enquanto profissionais do sexo, asseguram que não pretendem "se 
aposentar" tão cedo, por sentirem estar longe da terceira idade e também por gostarem de exercer tal profissão.

Siqueira (2012) propôs-se a investigar as narrativas biográficas e formas de sociabilidade de sujeitas - que não estão na linha da pobreza, são brancas/ morenas claras e têm residência própria - que se autodenominam "travestis das antigas", com a intenção de compreender como as participantes construíram suas formas de sociabilidade no que diz respeito às suas vivências no Rio de Janeiro. E, é claro, por meio do comparecimento de suas memórias, as participantes da investigação compartilharam histórias de preconceitos, discriminações constrangedoras de seus processos de subjetivação, bem como as estratégias de resistências, entendidas por elas como astúcias na tentativa de impor seus diferentes estilos de vidas.

A pesquisa de Casteleira (2013) é interessante por tratar do envelhecimento e da travestilidade a partir das narrativas de 4 (quatro) trans jovens - participantes com idades entre 20 e 29 anos - com a finalidade de descrever como elas constroem a velhice a partir de suas falas, no intuito de desvendar o modo no qual pessoas trans envelhecem, sob quais perspectivas e as soluções que estas sujeitas encontram para retardar o temeroso envelhecimento.

Essas participantes asseveram que sofrem um sistema duplo de invisibilidade - o do gênero e o da juventude - conforme se nota em outras pesquisas que envolvem a população LGBT e revelaram subverter não apenas as normativas de gênero e corporeidades, mas também a fronteira que demarca o início do envelhecimento. Para elas, a idade cronológica não é determinante para o marco do envelhecimento, mas as situações a que são submetidas enquanto profissionais do sexo. A chegada da velhice é identificada por meio do pouco rendimento de seus corpos, em consequência da perda da jovialidade, ficando as trans da pesquisa na expectativa do ingresso em atividades nas quais o corpo jovial não seja uma exigência (CASTELEIRA, 2013).

É curioso notar que os poucos trabalhos trazidos até aqui, no tocante ao envelhecimento de pessoas transgêneras, tratam quase que exclusivamente de travestis. Neste contexto, salientamos que há uma escassez de pesquisas que lidem com o envelhecimento de mulheres transexuais ou mulheres trans também. Muitos estudos encontrados, embora façam menção à velhice e/ ou ao processo de envelhecimento, não tratam a temática como foco. 
Envelhecer está intimamente ligado à percepção corporal. Nesse sentido, o corpo, segundo Foucault $(2007)^{48}$, está intimamente conectado à história e é instituído a partir de uma ordem fisiológica/biológica, mas acima de tudo - e acreditamos que de maneira mais marcante - tece resistências às imposições políticas, biológicas e culturais eleitas como as normais, naturais. E é na materizalição deste corpo que percebemos vestígios de diversas transformações, que, concomitantemente, nos revelam marcas corpóreas que registram as lutas travadas pelo controle deste mesmo corpo (FOUCAULT, 2007, 1996).

Foucault (2007) defende que o corpo consiste em um território no qual os efeitos de poder são manifestados, assim como representa um local em que se travam as lutas para resistir a esse mesmo poder. Nesse contexto, Foucault (2007) assevera que os corpos são moldados e adestrados pelas relações de poder no mundo moderno. $O$ corpo passa a ser a materialização do sujeito no mundo.

Seguindo essa lógica, os corpos das mulheres trans e travestis são desmerecidos por não estarem em concordância com os discursos biomédicos e logo sentem o poder sobre seus corpos em forma de patologização. Dessa forma, para serem aceitas em suas comunidades, elas precisam se sujeitar aos discursos socialmente impostos dos padrões de beleza e acabam submetendo-se a aplicações de silicone industrial para modelar os seios, quadris, glúteos; algumas submetem-se a cirurgias plásticas e ao consumo de hormônios, de maneira a beneficiar a indústria farmacêutica.

Percebemos, desta maneira, que o corpo sofre os efeitos das técnicas de poder, que se mostram por meio dos discursos e práticas sociais que $o$ influenciam e o configuram.

\section{Metodologia de pesquisa}

A escolha metodológica é de base interpretativista, pois busca pontos de vista subjetivos na descrição de situações sociais (FLICK, 2009). Respeitando tal proposta, nosso intuito foi trabalhar com entrevistas narrativas e

\footnotetext{
${ }^{48}$ As teorias queer vêm se debruçando sobre a questão de gênero e performatividade. Neste artigo, não focalizaremos este marco teórico, pela exiguidade de espaço e pelo objetivo do nosso texto, apesar de sermos conscientes da sua importância.
} 
semipadronizadas, combinadas para a geração dos dados. A temporalidade da pesquisa se limitou ao período de março de 2016 a setembro de 2018. A princípio, levantamos informações junto às participantes no tocante ao nome social, idade, cor, origem, escolarização e profissão, conforme exposto no quadro I. Deve-se ressaltar que todos os nomes que compõem este trabalho são fictícios e as participantes assinaram um termo de autorização para que pudéssemos utilizar os dados apresentados.

QUADRO I: IDENTIFICAÇÃO DAS SUJEITAS DA PESQUISA

\begin{tabular}{|c|c|c|c|c|c|c|}
\hline Nome & Idade & Cor & Região & Identidade & Escolaridade & Profissão \\
\hline Aman & 32 & Branca & MT & mulher trans & $\begin{array}{l}\text { Ensino superior } \\
\text { incompleto }\end{array}$ & $\begin{array}{l}\text { Cabeleira } \\
\text { Auxiliar de } \\
\text { cozinha }\end{array}$ \\
\hline Paty & 32 & Parda & MT & Transgênera & Ensino superior & $\begin{array}{l}\text { Secretaria } \\
\text { escolar }\end{array}$ \\
\hline Jess & 32 & Parda & MT & $\begin{array}{l}\text { Trans/gay } \\
\text { afeminado }\end{array}$ & $\begin{array}{l}\text { Ensino superior } \\
\text { incompleto }\end{array}$ & $\begin{array}{l}\text { Agente de } \\
\text { portaria } \\
\text { (segurança) }\end{array}$ \\
\hline Dri & 34 & Negra & MT & Travesti & $\begin{array}{l}\text { Ensino superior } \\
\text { incompleto }\end{array}$ & $\begin{array}{l}\text { Profissional do } \\
\text { sexo }\end{array}$ \\
\hline Carol & 42 & Parda & RJ & $\begin{array}{l}\text { Mulher trans/ } \\
\text { travesti }\end{array}$ & Ensino superior & Professora \\
\hline Gaby & 50 & Branca & $\mathrm{SC}$ & Travesti & Ensino superior & Professora \\
\hline Dê & 28 & Parda & MT & mulher trans & $\begin{array}{l}\text { Ensino superior } \\
\text { incompleto }\end{array}$ & $\begin{array}{l}\text { Professora } \\
\text { Estudante }\end{array}$ \\
\hline Carla & 54 & Parda & MA & Travesti & Não informou & $\begin{array}{l}\text { Profissional do } \\
\text { sexo }\end{array}$ \\
\hline Ju & 50 & Branca & MT & Travesti & Magistério & $\begin{array}{l}\text { Profissional do } \\
\text { sexo }\end{array}$ \\
\hline Beca & 51 & Parda & SE & Travesti & Ensino superior & Professora \\
\hline Faby & 33 & Negra & MT & Transexual & $\begin{array}{l}\text { Ensino superior } \\
\text { incompleto }\end{array}$ & Cabelereira \\
\hline
\end{tabular}

Fonte: Elaborado pelos pesquisadores

A maioria das entrevistas foi realizada individualmente, mas nem todas foram presenciais e/ou contínuas. Uma vez que algumas das participantes moravam em diferentes regiões brasileiras, utilizamos redes sociais para nos comunicarmos e entrevistarmos algumas delas; as entrevistas presenciais foram registradas por meio de gravador de voz. Os registros contavam com 
um diário de campo, para que pudéssemos anotar gestualidades, expressões faciais, gírias e comentários, bem como percepções que facilitassem a compreensão dos áudios na etapa da análise dos dados.

As entrevistas não eram lineares; mesmo havendo um roteiro de questões previamente estabelecidas, conversamos com as participantes inúmeras vezes, não apenas acerca do previsto no roteiro, mas também acerca de dúvidas que surgiam quando as entrevistas eram transcritas.

Dentre os temas recorrentes, constatamos como sendo o primeiro a violência verbal, física ou psicológica, além das visões e definições acerca do processo de envelhecimento, o que nos remete à observação de outros, como futuro, beleza, posições de destaque nas comunidades, prostituição. Após a divisão por temas e a evidenciação dos relatos, iniciamos a seleção para a análise dos dados mais representativos.

\section{0 que os dados nos falam?}

A análise dos dados aponta que a agressão verbal e simbólica sofrida pelas mulheres trans e travestis afeta diretamente seu processo de envelhecimento. Salientamos que as ofensas não são sofridas apenas nas ruas e nos locais de prostituição, mas perpassam as inúmeras esferas de suas vidas. Uma dessas esferas diz respeito ao atendimento à saúde nas unidades públicas.

\section{Excerto 1}

... Aí a menina foi violentada e nós levou ela pra UPA né.... Depois de uma tarde inteira é que foram fazer a profilaxia nela. Só porque era travesti deixaram a menina esperando o dia todo. (Anotação no Diário de Campo. Dri me contava como foi o atendimento a uma menina que tinha sido recentemente violentada sexualmente e espancada, além de ter os objetos pessoais roubados no horário de trabalho. 22 jan. 2018).

\section{Excerto 2}

... aí toda vez que a gente precisa do serviço daquela enfermeira, ela fica zombando da gente, deixa a gente nessa situação. Acredita que ela chegou e ficou falando que hoje não era dia de prevenção da AIDS? (Anotação no Diário de Campo. Dri e Jus contavam a respeito do atendimento de uma enfermeira em um posto de saúde da família que atende as mulheres trans e travestis da casa de cafetinagem. 20 fev. 2018). 
Os excertos 1 e 2 delineiam o tratamento vivenciado pelas participantes ao necessitar de atendimento na rede pública de saúde. Ao procurar os serviços oferecidos na Unidade de Pronto Atendimento Municipal, elas alegam ter esperado a tarde inteira por atendimento, bem como afirmam que viram diversas outras pessoas, que tinham chegado depois delas, serem passadas à frente. Como elas nos relataram, o atraso no atendimento poderia ter causado danos à saúde da travesti que necessitava de atendimento urgente. É como se os corpos dessas mulheres precisassem ficar expostos para a apreciação pública, julgamento, acareação, humilhação, antes de serem atendidas de maneira a lhes apontar quem se encontra no topo das relações de poder.

Uma vez que é sobre o corpo que recaem as estratégias de poder (FOUCAULT, 2007), ele também se torna um ambiente de nomeação de saberes (FOUCAULT, 2007), saberes que determinam o padrão de corpo a ser seguido e a patologização daqueles considerados desviantes. Os desviantes, deste modo, sofrem as punições, como a exposição à avaliação pública, riscos à saúde, humilhações. Soma-se a tal problemática o fato de os corpos trans e travestis representarem um aglomerado de carne e ossos que não possuem um gênero socialmente definido e aceitável pelo discurso heterocisnormativo, o que justifica a falta de respeito por parte dos servidores na unidade de atendimento de saúde pública.

Como nos locais de atendimento de saúde as travestis e mulheres trans não recebem o tratamento que consideram digno e respeitoso, elas recorrem às "tias" ou "vós". Ju e Carla são dois exemplos de travestis constantemente procuradas por travestis/mulheres trans da casa onde moram para oferecer conselhos de toda ordem, não apenas no tocante à saúde: "Elas sabem que nós já passou por muita coisa né?", como Ju expressa. Carla revela que mesmo algumas das meninas sendo mais "ousadas" e não levando tudo em consideração, "quando é sobre a saúde delas elas pede ajuda... assim, eu sou mais experiente...".

Alguns trabalhos, como os de Sander e Oliveira (2016), Nogueira (2013), indicam que as travestis e mulheres trans "novinhas" inúmeras vezes procuram as "tias" ou "vós" para serem aconselhadas nos quesitos saúde, transição e construção corporal, sociabilidade. Igualmente, ter chegado aos 50 anos (ou mais), além de representar uma vitória contra as inúmeras violências e opressões, pode transformar essas mulheres em referências para as demais meninas que estão começando as suas vidas enquanto mulheres trans/travestis. 
Ju conta que "elas procura pra saber de alguma coisa, pedir uma ajuda", por entenderem que Ju está no grupo que já abriu muitas portas e venceu muitas batalhas para a geração que está "fazendo pista hoje". Carla, por outro lado, não se acha velha nos seus mais de 50 anos, mas se sente experiente, e mesmo assim diz: "eu ensino as menina".

Os dados revelam que as travestis mais velhas são reconhecidas pela sua experiência e, ao mesmo tempo, desvalorizadas por serem idosas para aquele grupo social. Carla, por exemplo, conta que as meninas da casa de cafetinagem onde mora a procuram quando querem algum conselho, mas quando é pra falar sobre segurança e violência "elas não gosta do que nois fala não. Aí eu falo pra elas que tem que se cuidar elas acha ruim, fica rebelde... chama nois de bicha velha, bicha doida, exagerada...". Carla chegou a reclamar que "...às vezes elas é cabeça dura, num qué escuta a gente, nem aceita...”. A frustração de Carla pode ser percebida, pois ela faz parte de uma geração que desafiou valores e discursos para as futuras gerações, as "novinhas". E, na verdade, o que a entristece é o fato de as mais jovens não reconhecerem que são inexperientes e menosprezarem aquelas que abriram os caminhos para elas.

Concomitantemente, ocorrem experiências mais colaborativas e tensões nesse processo entre as travestis mais velhas e mais novas. Beca complementou também que são as mais velhas que "guiam as mais novas, mostram por onde trilhar", visto que são elas que já passaram pelas dificuldades, mas que "essa nova geração também é fogo, chegou cheia de razão e ousadia". Esse fato é observado também entre as participantes das pesquisas de Siqueira (2004), Antunes (2010) e Nogueira (2013).

Quando o assunto é HIV/AIDS, é unanime entre as travestis/mulheres trans mais velhas a ofensa que impõe um rótulo que não lhes pertence. De outra via, ser uma travesti/mulher trans que alcançou os cinquenta anos sem ter contraído a doença é ostentar um status social entre as demais meninas de suas comunidades.

Ao entrar no assunto com Ju, esta prontamente exclamou: "Vixi, Maria! Estar com a tia ${ }^{49}$ ? Graças a Deus tenho esse negócio aí não!” Em concordância com Siqueira (2004), é certificado de status às mulheres trans e travestis que alcançaram a maturidade e escaparam da onda da AIDS. Ju, Carla e Beca

49 "Estar com a tia" é uma expressão muito comum entre a comunidade LGBT para se referir à contaminação pelo vírus HIV/AIDS. 
são exemplos ${ }^{50}$. Tal fato se repete com a pesquisa de Nogueira (2013), em que a autora notou o lugar de destaque ocupado por travestis que chegam à velhice sem terem contraído AIDS. De acordo com a pesquisa desse autor, contrair HIV/AIDS posiciona a pessoa transgênera em um lugar ainda mais estigmatizante.

Retomando a temática da violência, Beca expressou que "a violência sofrida pelas travestis nas ruas não é o fator determinante para o envelhecimento precoce das meninas", mas é acentuado pelas outras formas de violência enfrentadas cotidianamente, como a "falta de respeito da sociedade, falta de moradia fixa e própria, situação financeira precária, noites sem dormir e desgaste emocional", colocando travestis e mulheres trans em posição de defesa e tensão em tempo integral.

Um corpo exposto a tais violências, dificilmente, consegue gozar de um processo de envelhecimento ditado pelo Estatuto do Idoso - documento com normativas que abarcam apenas o envelhecimento de pessoas cisgêneras e que excluem o processo de envelhecer de pessoas transgêneras.

Levando-se em linha de conta as ameaças, os ataques fisicos, as agressões psicológicas e em ambientes de uso comum de todos os cidadãos e cidadãs do país, não é possível que travestis e mulheres trans alcancem um envelhecimento saudável e digno. Assim, indagamos a cada uma delas se tanta opressão e truculência vivenciadas no decorrer de suas vidas pode ser um fator marcante e acelerador de seus processos de envelhecimento:

Excerto 3

O trabalho nas ruas não é nada fácil. Diante de todos os riscos a que são submetidas, posso sim afirmar que elas envelhecem mais cedo (Carla, 12 abr. 2018).

\section{Excerto 4}

...eu já sou uma idosa (risos)... cheguei aos 34 anos. A gente só vive até os 35... tenho um ano de vida (Dri, 14 abr. 2018).

\footnotetext{
${ }^{50}$ Acreditamos ser relevante explicar aqui que nenhuma das entrevistadas da pesquisa relatou ser portadora do vírus HIV/AIDS. Fizemos menção à Beca, Carla e Ju pois foram as únicas que falaram a respeito da temática. Dri comentou certa vez que acolheram na casa de cafetinagem uma menina portadora do vírus HIV/AIDS e que enfrentava problemas com o vício em drogas e bebidas, mas não nos revelou a identidade dessa menina, muito menos nos informou a sua idade. Não sabemos dizer se ainda vive na casa.
} 


\section{Excerto 5}

Elas fazem uso de muita bebida e drogas para aguentar as dificuldades nas ruas, na pista. Isso somado à todo tipo de violência física que elas enfrentam contribui para o seu envelhecimento (Gaby, 16 jan. 2018).

Em outros momentos, comentamos acerca do curto tempo de vida das mulheres trans/travestis, expresso pela própria Dri. Casteleira (2013) confirma que a fronteira entre a idade jovem e o envelhecimento não se constrói por meio da idade cronológica, mas em conformidade com vivências de cada uma dessas mulheres, o que poder variar, conforme é reforçado por Dri, que tem 34 anos e se sente uma pessoa idosa.

Como vimos, essas sujeitas enfrentam violências verbais pelo simples fato de saírem de casa. Tais violências, advindas da sociedade como um todo, as coloca em situações de extremo estresse e tensão, colaborando para uma possível depressão.

Diante de todos os excertos apresentados e discutidos até aqui, se observarmos que todos são oriundos de narrativas produzidas por travestis e mulheres trans ao evidenciar o que elas consideravam mais incômodo em suas vivências, podemos perceber que, seguramente, a violência é uma das mais recorrentes situações que diretamente afetam as suas condições de vida e, consequentemente, um de seus efeitos mais devastadores é a antecipação do processo de envelhecimento.

Para entender melhor as concepções de envelhecimento para nossas participantes, perguntamos como elas defineriam envelhecimento. As respostas pareceram apontar para uma variedade de sentidos, como podemos ver nos excertos que seguem:

\section{Excerto 6}

é ficar mais madura, né? (risos) não sei explicar direito. Quase nunca penso nisso (Faby, 13 jul. 2018).

\section{Excerto 7}

Cada um tem sua própria maneira de envelhecer (Dê, 15 jul. 2018).

\section{Excerto 8}

Menina, sai pra lá com isso. Nem quero pensar nisso! (Paty,23 mai. 2016). 
Iniciamos a discussão do significado de envelhecimento a partir das falas de Faby, Dê e Paty, especialmente porque essas participantes encontram-se na faixa etária entre os 25 e 35 anos, de modo a representar o grupo geracional mais jovem dentre as participantes deste estudo. Os relatos indicam a incerteza, a insegurança das participantes em expressar o significado do termo velhice e do processo de envelhecimento, possivelmente por não terem experimentado fisicamente nenhum dos efeitos do envelhecimento biológico. Além disso, essas participantes fazem parte de uma geração que é apoiada por recursos tecnológicos e estéticos que não existiam à disposição de gerações passadas (OLIVEIRA; MEIRA, 2016), o que explica o fato de ser comum nesse grupo geracional a falta de compromisso em refletir acerca da temática.

Aman, uma participante do mesmo grupo geracional também nos esclarece, acerca do envelhecimento: “... acho que não parei pra pensar nisso ainda não... tá longe né?”; desse modo, elucida que não é hora de se pensar a respeito, possivelmente está muito nova pra esse tipo de preocupação. Já Dri nos contou que nunca parou pra pensar acerca do processo de envelhecimento em si, uma vez que "...minha ficha não caiu pra essa vibe de velhice... nem sei se vou passar dos 35".

Dri, Aman, Faby e Dê, a geração das mulheres trans e travestis novinhas nesta pesquisa, deixam bem claro que preferem não se debruçar sobre o tema envelhecimento, talvez por não terem sentido em seus corpos as marcas do tempo se instalarem ou por não conseguirem enxergar uma possibilidade de futuro após os 35 anos de idade.

Como a própria Dri já informou em outro momento, pessoas trans e travestis vivem até aproximadamente os 35 anos, sendo essa a idade média estimada de vida de uma transgênera no Brasil (SALES, 2018; SIQUEIRA, 2004; 2008), constituindo-se a velhice entre as mulheres trans e travestis um fenômeno que as atinge de modo precoce, se comparado às pessoas cisgêneras, principalmente se levarmos em conta as trajetórias de vida delineadas por quadros de violências dos mais variados tipos (ANTUNES, 2010), como discutido. 


\section{Reflexões finais}

Neste artigo, buscou-se analisar narrativas de mulheres trans e travestis visando perceber quais sentidos são dados ao processo de envelhecimento para essa comunidade. Teoricamente nosso trabalho teve suporte de caráter mais discursivo e estudos em torno do conceito de corpo e envelhecimento.

A partir da análise realizada, colhe-se que os enunciados sugerem que a violência física e emocional sofrida pelas mulheres trans e travestis tende a influenciar o envelhecimento precoce, em virtude das dificuldades experimentadas no decorrer de suas vidas. Além disso, esse envelhecimento pode ser um momento de perda da beleza física, acarretando sua perda de campo de trabalho na prostituição, tornando-se, portanto, cada vez mais miseráveis.

Devemos, portanto, fazer uma diferenciação entre o envelhecimento de homens e mulheres cisgêneros e entre homens e mulheres transgêneros, visto que, embora esse fenômeno afete todos os indivíduos vivos, cisgêneros ou transgêneros, as necessidades de cada categoria identitária são diferentes; daí a inevitabilidade de políticas públicas específicas que atendam a cada um desses grupos. Além disso, os modos de vida de pessoas cis muito divergem do modo de vida de pessoas trans, se levarmos em linha de conta que as cisgêneras são detentoras das forças de poder e privilégios que tornam suas vidas mais fáceis. Acreditamos que futuras pesquisas precisariam se debruçar mais detalhadamente sobre o envelhecimento da comunidade trans, assunto completamente ignorado ainda pelos estudos da linguagem. 


\section{REFERÊNCIAS}

ANTUNES, P.P. S. Travestis Envelhecem? Dissertação (Mestrado em Gerontologia) - Pontifícia Universidade Católica de São Paulo, São Paulo, 2010.

CASTELEIRA, R. P. Sereias também envelhecem: memória, corpo e travestilidade. Dissertação (Mestrado em Ciências Sociais) - Centro de Ciências Humanas, Letras e Artes, Universidade Estadual de Maringá, UEM, Maringá, 2014.

FLICK, U. Introdução à pesquisa qualitativa. Trad. Joice Elias Costa. 3. ed. Porto Alegre: Artmed, 2009. 405p.

FOUCAULT, M. A arqueologia do saber. Trad. Luiz Felipe Baeta Neves. 7. ed. Rio de Janeiro: Forense Universitária, 2008.

FOUCAULT, M. Microfísica do poder. Trad. Roberto Machado. Rio de Janeiro: Edições Graal, 2007.

FOUCAULT, M. A ordem do discurso. Aula inaugural no Collége de France pronunciada em 2 de dezembro de 1970. Trad. Laura Fraga de Almeida Sampaio. São Paulo: Loyola, 1996.

FOUCAULT, M. Vigiar e Punir. Petrópolis: Vozes, 1987.

JESUS, J.G. Orientações sobre identidade de gênero: conceitos e termos: guia técnico sobre pessoas transexuais, travestis e demais transgêneros, para formadores de opinião. 2 . ed. Brasília, 2012.

MOITA LOPES, L. P. (org.). Por uma linguística aplicada INdisciplinar. São Paulo: Parábola, 2006.

MOTA, M. P. Homossexualidade e Envelhecimento: algumas reflexões no campo da experiência. SINAIS - Revista Eletrônica - Ciências Sociais, Vitória: CCHN, UFES, v.1, Edição n. 06, p. 26-51, dez. 2009.

NOGUEIRA, F. J. S. Mariconas: itinerários da velhice travesti, (des)montagens e (in) visibilidades. 230 p. Tese (Doutorado em Sociologia) - Centro de Letras e Artes, Departamento de Ciências Sociais, Universidade Federal da Paraíba, João Pessoa, 2013.

RODOVALHO, A. M. O cis pelo trans. Revista Estudos Feministas, Florianópolis, 25(1): 422, jan./abr. 2017.

SALES. A. Travestis brasileiras e escolas (da vida): cartografias do movimento social organizado aos gêneros nômades. 2018. 310 p. Tese (Doutorado em Psicologia) - Faculdade de Ciências e Letras, Universidade Estadual Paulista-UNESP, Assis.

SANTOS, S. C. Concepções teórico-filosóficas sobre envelhecimento, velhice, idoso e enfermagem gerontogeriátrica. Revista Brasileira de Enfermagem, v. 63 n. 6, p. 1035-1039, 2010.

SANTOS, S. M.; SILVA, J. A. M; BRANDÃO, S. M. M.; CORDEIRO, G. S. Discussão da sexualidade na velhice: gênero e geração. In: $18^{\circ}$ REDOR. Perspectivas Feministas de Gênero: desafios no campo da militância e das práticas, 2014, Recife. Anais [...]. Recife: UFRP, 2014. 
SANTOS, T. N.; CARMO, Q. S. Lesbiandade, envelhecimento e autocuidado entre lésbicas feministas com mais de cinquenta anos. III Seminário Internacional Enlaçando Sexualidades. 2013. Anais [...].

SANDER, V.; OLIVEIRA, L. H. "Tias" e "novinhas": envelhecimento e relações intergeracionais nas experiências de travestis trabalhadoras sexuais em Belo Horizonte. Revista Soc. e Cult., Goiânia, v. 19, n. 2, p. 69-81, jul./dez. 2016. Disponível em: https://www.revistas.ufg.br/fchf/ article/viewFile/48671/23894. Acesso em: 21 nov. 2018.

SIQUEIRA, M. S. Sou senhora: um estudo antropológico sobre travestis na velhice. 2004. 148f. Dissertação (Mestrado em Antropologia Social) - Centro de Filosofia e Ciências Humanas, Programa de Pós-Graduação em Antropologia Social, Florianópolis. 


\title{
PROSTITUIÇÃO MASCULINA EM CONTEXTOS TRANSNACIONAIS: PROJETOS, CAMPOS DE POSSIBILIDADES E AGÊNCIA EM LISBOA
}

\author{
Guilherme R. Passamani \\ Marcelo Victor da Rosa \\ Jônatas Stritar Alaman \\ Tatiana Bezerra Lopes
}

Este texto é parte de um projeto de pesquisa sobre prostituição masculina no Brasil, desenvolvido entre 2016-2020, no Núcleo de Estudos Néstor Perlongher - Cidade, Geração e Sexualidade, na Universidade Federal de Mato Grosso do Sul. Em nosso país, as pesquisas sobre prostituição em contextos transnacionais são mais significativas no campo da prostituição de mulheres e travestis, a partir de autores como Adriana Piscitelli (2013), Ana Paula da Silva e Thaddeus Blanchette (2005), Ana Paula da Silva (2015), Larissa Pelúcio (2011), entre outros. Sobre prostituição masculina em contextos transnacionais, especificamente, há um número muito menor de pesquisas.

É importante salientar que Portugal tem se tornado ultimamente, para além de uma opção turística "mais barata" em relação a outros países da Europa, um destino frequente para brasileiros passarem a residir ${ }^{51}$. Esse movimento migratório teve um aumento considerável a partir dos últimos governos socialistas em Portugal, que investiram nas chamadas políticas de "bem-estar social" e, no último período, coincidiram com os anos de retrocessos políticos, democráticos e econômicos no Brasil. Além desses fatores, que aparecem nas falas de nossos interlocutores, Portugal é

\footnotetext{
${ }^{51}$ https://noticias.uol.com.br/ultimas-noticias/agencia-estado/2019/07/14/os-varios-brasis-quese-mudaram-para-portugal.htm. Acesso em 15 de fevereiro de 2020.
} 
considerado um dos países mais seguros do mundo, o que funciona como um atrativo diante de um planeta cada vez mais inseguro ${ }^{52}$.

No entanto, em que pese toda essa propaganda positiva do país, nossos interlocutores apontam duas questões principais para a escolha de Portugal como destino: a posição geográfica e a língua. Para os interlocutores, Portugal funciona como uma porta de entrada para o restante da Europa. Segundo eles, é mais fácil chegar a Portugal em função do custo de vida e das facilidades da língua. A partir de Portugal, então, são acessados outros países a fim de que se possa desempenhar o trabalho sexual em diferentes lugares, ganhando diferentes montantes, especialmente, nos países mais ricos. O segundo elemento destacado é a língua. Os interlocutores de nossa pesquisa, basicamente, só falam português.

Esse capítulo, em um primeiro momento, apresentará um olhar sobre as experiências de nosso interlocutor-chave em sua cidade de origem. Ali, começaremos a delinear a prostituição como um projeto e os primeiros tempos em Portugal. Em um segundo momento, atentaremos, especificamente, para a prostituição de brasileiros em Portugal. Analisaremos os diferentes equipamentos onde se desenvolve o negócio, bem como as expectativas sobre os brasileiros, como uma suposta racialização do desejo, suas particularidades no mercado do sexo local e a circulação por outros países.

\section{A prostituição masculina como projeto: entre campos de possibilidades}

Aqui, discutiremos com nosso interlocutor-chave que trocou, há dois anos, a vida de estudante de geografia e instrutor de capoeira em Campo Grande pela prostituição em Lisboa e outras cidades europeias, na esteira de outros amigos que teriam feito a mesma rota um pouco antes dele. Henrique $^{53}$ tinha 25 anos quando nos encontramos ${ }^{54}$, se considera pardo,

\footnotetext{
${ }^{52}$ https://www.jornaldenegocios.pt/economia/detalhe/portugal-sobe-a-terceiro-pais-mais-pacificodo-mundo. Acesso em 15 de fevereiro de 2020.

${ }^{53}$ Henrique é o nome fictício que o próprio interlocutor usa no seu trabalho. Ele nos autorizou a utilizar o mesmo pseudônimo para nos referirmos a ele na pesquisa.

${ }^{54}$ Nosso primeiro encontro foi realizado em Lisboa em dezembro de 2018 e depois, um segundo encontro, foi realizado em junho de 2019 na mesma cidade.
} 
tem $1,82 \mathrm{~m}$ e pesa $79 \mathrm{~kg}$, tem um corpo que poderíamos considerar malhado, por conta da definição muscular bastante visível.

As redes que nos levaram a Henrique foram acionadas ainda na pesquisa de campo da tese de doutorado de um dos pesquisadores, na cidade de Corumbá ${ }^{55}$. Durante a investigação, o pesquisador conheceu Jeferson, um garoto de programa local, que se relacionava com homens mais velhos (Passamani, 2018). Jeferson, segundo Henrique, teria sido o primeiro de um grupo de amigos a ir para Lisboa se prostituir e que teria conseguido se "dar bem", dando início, assim, a uma espécie de rota de sul-matogrossenses para a cidade portuguesa com a mesma finalidade.

A figura do "amigo que foi para Portugal se prostituir" parece ser o polo que ajuda a desenrolar um novo projeto, provocando câmbios em uma trajetória já delineada e apresentando um novo campo de possibilidades que, de certa forma, provoca metamorfoses na vida de Henrique. Gilberto Velho desenvolve a noção de projeto a partir de Alfred Schütz (1974). Schütz entendia como projeto uma forma de melhor explorar condutas estabelecidas para alcançar determinados objetivos. Esse ponto é destacado por Velho ao definir projeto como uma ação relacional, isto é, guarda uma dimensão individual e outra coletiva. Essa relação é que permite fazer com que se alcance determinados fins vinculados a uma realidade externa ao sujeito que não era dada, imaginada, anteriormente (Velho 1994).

Assim, é que podemos compreender como o novo projeto vai transformando o nosso interlocutor. Henrique nasceu e viveu até os 23 anos em Campo Grande. Ele é filho de pais que "não são ricos, nem são pobres", sempre teve o que precisou sem ter a necessidade de, desde cedo, começar a trabalhar. Estudou em escola pública e prestou o serviço militar. Ao sair do Exército, prestou seleção para Geografia e foi classificado. Aqui há uma trajetória bem traçada e esta trajetória enseja um campo de possibilidades, isto é, um espaço para criar e implantar projetos individuais, mas também coletivos (Velho 1994).

Henrique conta que a vida em Campo Grande era tranquila, mas que sempre parecia faltar algo. Não havia uma ausência de projeto, havia um

\footnotetext{
${ }^{55}$ Corumbá é uma cidade do Estado de Mato Grosso do Sul. Ela tem, por volta de, 110 mil habitantes e situa-se na fronteira com a Bolívia, na região do Pantanal. Está distante $425 \mathrm{~km}$ da capital do Estado, Campo Grande.
} 
projeto articulado a determinado campo de possibilidades circunscrito a determinada realidade, ou seja, o curso de geografia e as implicações desta graduação na sua vida pessoal e profissional. No entanto, conforme conta o interlocutor, "faltava um frio na barriga".

O início dos contatos sexuais com homens retoma alguns clichês: festa, noite, bebidas em excesso. Os homens que interessavam Henrique tinham em torno dos 40 anos, nada, ou quase nada afeminados, mas que demonstrassem algum tipo de sinal de interesse nele. Esse tipo específico de homem, que podemos chamar de coroa, já foi trabalhado nas pesquisas de Julio Simões (2004). Pode-se dizer que esse homem mais velho não se enquadra na categoria velho, geralmente estigmatizada por uma ideia de decrepitude e perda de autonomia. O coroa tem mais experiência, independência, desfruta de algumas vantagens da vida adulta, quase sempre é discreto e consegue, vez ou outra, bons ganhos no mundo da paquera. No caso de Henrique e seus coroas, ele teve vários encontros furtivos em festas privadas e em baladas.

É preciso investir um pouco mais na compreensão da ideia de campo de possibilidades, pois ela será determinante aqui para pensar as mudanças que começavam a operar na trajetória de Henrique. Segundo Gilberto Velho, o campo de possibilidades "trata do que é dado com as alternativas construídas do processo sócio-histórico com o potencial interpretativo do mundo simbólico da cultura" (1994, p. 28), ou seja, é um conjunto de possibilidades que se apresenta ao sujeito a partir de processos e contextos nos quais ele está ou passa a estar inserido.

Ter conhecido Jeferson foi um momento marcante no processo de mudança de Henrique, que culminou com a ida para Portugal, pois alargou seu campo de possibilidades. A ideia de que Henrique poderia ganhar dinheiro com seu público-alvo foi dada por Jeferson. Isso descortinou uma série de novas camadas para o projeto já tão organizado de Henrique em Campo Grande. Ou seja, a relação entre os dois nos mostra que projetos são processos complexos, que podem alterar trajetórias individuais e coletivas, mas, mais que isso, cuja pertinência vai sendo testada e definida contextualmente.

Projetos são elaborados no âmago de relações de poder, portanto há conflitos, tensionamentos e disputas permanentes. No caso dos novos projetos que começavam a se desenhar para Henrique não foi diferente. 
Até porque os projetos são elaborados a partir dos novos campos de possibilidades que se apresentam. Do ponto de vista teórico, para Gilberto Velho (1994), metamorfose é o resultado da alteração dos projetos por inúmeras razões. Os projetos são estruturados, mas algumas vezes não conseguem ser implementados e, por consequência, são alterados. Tais alterações reorganizam as trajetórias dos sujeitos ou dos grupos. A capacidade ou necessidade de alterar projetos ao longo da trajetória é que se reconhece como metamorfose.

Assim, esta nova etapa da trajetória de Henrique, alterando seu projeto inicial, dando corpo a outros projetos, a partir dos novos campos de possibilidades, inicia-se a partir da prostituição nas ruas. Conforme nos mostra a literatura brasileira sobre prostituição masculina de rua (Perlongher, 1987), esta sempre foi vista como mais barata porque mais perigosa e porque mais suja, uma vez que a rua, especialmente à noite, é compreendida como o lugar de ninguém, o lugar da indiferença, o lugar do anonimato.

Para Henrique, a rua foi passageira e não exatamente lucrativa. No entanto, segundo ele, havia mais que a necessidade de dinheiro, havia algo como a busca por novos limites para o prazer, levar o desejo até as últimas consequências. Perlongher (1987), ao falar dos tensores libidinais, enquanto articulação de diferentes categorias, mostra como prazer, violência e perigo se aproximam no negócio do desejo. 0 desafio de ganhar dinheiro no limiar do prazer e do perigo era a "tara" de Henrique. Algo como o que Maria Filomena Gregori (2016) chamou, oportunamente, de limites da sexualidade, aquele ponto que aproxima meticulosamente prazer e perigo nos negócios da sexualidade.

Henrique sai das ruas do centro de Campo Grande e vai para as saunas. Aliás, esta parece ter sido uma tendência. Ocorreu uma espécie de migração das ruas e demais espaços públicos, para as saunas e clubes de sexo, ou seja, espaços privados. Essa privatização do desejo se deveu, conforme apuramos em trabalho anterior, à compreensão da sauna como um espaço mais limpo, mais seguro, "de melhor nível", onde os clientes são "mais selecionados" (Passamani, Rosa, Lopes, 2020).

Esse dualismo entre o público e o privado é uma invenção da modernidade. Conforme Prado Filho (2018), a modernidade se constrói a partir de campos de experiência, sendo um deles a cultura, formando 
valores éticos (racionalista). No feudalismo não existe o privado, só na modernidade somos um sujeito dentro de casa e outro fora de casa e isso constitui nossa subjetividade. Para o autor, a modernidade introduziu suas próprias tecnologias e jogos de poder, como as técnicas de individualização.

Oras, a sauna é um espaço privado, onde os corpos são vigiados, porém as técnicas de controle da subjetividade são muitas. Como forma de distinguir tais técnicas de vigilância, podemos citar o entendimento de que, sendo a homossexualidade percebida por alguns segmentos mais conservadores como uma prática pecaminosa, as instituições cristãs reprovam a existência de saunas destinadas aos homens. Por outro lado, os frequentadores das saunas vigiam os corpos gordos, magros, velhos e promíscuos que circulam em tais locais.

A sauna, para Henrique, teria sido "um prato cheio", tendo, neste local, conseguido muitos clientes. Na época em que se prostituía nas saunas, algo proibido naqueles estabelecimentos, mas que ocorria "por baixo dos panos", tinha uma namorada e precisou construir estratégias variadas para que suas vidas não interferissem uma na outra. Paralelo às saunas, Henrique também buscava clientes na sala de chat do site UOL de Campo Grande. Ele usava apelidos variados, sempre seguidos de \$ e fazendo alusões a ser ativo e bem dotado.

No chat, homens de idades e perfis variados o contatavam. Ser ativo e bem dotado eram signos que acenavam a uma masculinidade hegemônica e que garantiam ao interlocutor sucesso no negócio do desejo. Essas e outras estratégias são descritas como características importantes a serem acionadas nessa modalidade online de interação, conforme Richard Miskolci (2009, 2013).

Uma última estratégia, antes da mudança para Portugal, foi criar perfis nos aplicativos de relacionamento entre homens. $O$ interlocutor criou perfis no Scruff, Grindr, Hornet e também no Tinder. Para ele, o mais lucrativo teria sido o Grindr. Nos últimos anos, houve uma popularização dos perfis de garotos de programa nesses aplicativos, demonstrando, quem sabe, mais um deslocamento nas mudanças que atingem a prostituição masculina ${ }^{56}$.

A história de Henrique se enquadra naquilo que Gilberto Velho chamaria de curva de vida, isto é, o resultado, ao longo das múltiplas experiências do

${ }^{56}$ Para mais detalhes sobre os usos dos aplicativos na "paquera", ver Braga (2013). 
sujeito, das mudanças sofridas para que se consiga alcançar, a bom turno, os novos projetos. Isso se fez a partir de alterações na trajetória pensada inicialmente. Também houve negociações, descobertas, tensões, mudanças, experimentações. Se, como diz Velho, “o projeto é a conduta organizada para atingir finalidades específicas" (1994, p. 101), a heterogeneidade de situações, a pluralidade de experiências a que ele esteve sujeito, ensejaram o surgimento de uma nova carreira, conforme Edgar Schein (1993). Essa carreira como garoto de programa, ainda que não visível para o conjunto mais próximo de pessoas com o qual ele convivia, o projetou a outros contextos.

Essa metamorfose toda foi muito rápida, durando dois anos e o levando, segundo conta, a um "cansaço" de Campo Grande. Foi nesse momento que reencontrou Jeferson. Jeferson tinha ido para São Paulo em 2015 e no mesmo ano seguiu para Lisboa. O reencontro deles, em 2016, marcaria outra metamorfose na vida de Henrique. Trajetórias e projetos se alteravam outra vez. E, também, novos campos de possibilidades se desenrolaram. Jeferson contava "maravilhas" da prostituição masculina na Europa, onde Lisboa teria sido sua porta de entrada. Isso despertou o interesse de Henrique e parecia ser a possibilidade de romper com os laços familiares mais estreitos, bem como com o namoro.

Henrique contou que teria ido para Portugal, pelo menos isso é o que ele tinha dito à família, ser instrutor de capoeira, tal como Jeferson. Sair de Campo Grande, ir para a Europa e poder "agir" com mais liberdade em relação à prostituição, naquele momento, era tudo que ele queria. No final de 2016 embarcou para Portugal. Passou os primeiros tempos na casa de Jeferson, uma espécie de "porta de entrada" para os garotos de Mato Grosso do Sul que iam se prostituir na Europa.

O fato de Henrique ser um capoeirista e ter escolhido Portugal como destino para atuar como garoto de programa não é por acaso. Tal “álibi” pode ser lido como uma estratégia de vivência de uma sexualidade dissidente a partir de uma "zona de segurança". Ou seja, ao afirmar-se como capoeirista, ele se "afasta" do estigma de ser garoto de programa e, ao migrar para um país estrangeiro, tem a possibilidade de manter-se protegido do olhar moralizante de sua rede de relações mais próxima.

Henrique não é o único brasileiro que internacionaliza a capoeira. Nesse contexto, lançamos uma questão: existe alguma aproximação entre 
a capoeira e a prostituição masculina? A história do Brasil Imperial, após o término da escravatura, fim do século XIX, colocou no mesmo lugar de crimes policiais a vadiagem, a capoeira e a prostituição, segundo Harriet Santos e Juciene Apolinário (2010). Nesse sentido, Mateus Almeida (2015) complementa este entendimento ao mencionar o caráter de moralidade presente nessas atividades citadas. Para o autor, quem se prostituía e jogava capoeira, praticava o ócio e, com isso, tais sujeitos não produziam pela força do seu trabalho bens para a sociedade, resultando em falta de dignidade.

Conforme Celso de Brito (2007), o capoeirista era visto como um malandro, que não trabalhava, o que no universo da prostituição também é algo bem recorrente. A prostituição também carrega em sua história uma aproximação com a violência, com algo sujo, da noite, das drogas. Se, na capoeira do século XIX, o capoeirista e a malandragem eram algo denotativo, hoje a malandragem ganha outros significados que formam o sujeito capoeirista como alguém apto a jogar e/ou ensinar essa arte. Na prostituição, os garotos que são "malandros" sobrevivem melhor, principalmente quando a prostituição é realizada na rua.

Segundo Bruno Andrade (2012), a construção de uma identidade subalterna não é um produto certo, mas as relações de poder produzidas nesse processo tensionam o colonial e a modernidade. Isso se revela nas experiências internacionais da capoeira. Mesmo em países em que a língua mãe não seja o português, a lusofonia está presente. Tal subalternidade não fixa nos capoeiristas uma identidade de subalternos, pois, como bem analisa Adriana Piscitelli (2010), existe uma relação intensa entre a capoeira a uma economia do desejo. Celso de Brito (2007) expressa que a malandragem na capoeira é uma forma de sedução. O poder de seduzir produz certamente uma positividade difícil de ser percebida e de ser relacionada a efeitos negativos nas relações estabelecidas.

Adriana Piscitelli (2010), em sua pesquisa acerca das mulheres brasileiras que migram para a Europa, nos aponta que os homens capoeiristas chamam mais a atenção das mulheres estrangeiras, pois seus corpos revelam virilidade e seus efeitos são de valorização frente aos homens locais com seus corpos comuns. Além da virilidade, a pele morena, corpos definidos e/ou musculosos seduzem. Aqui, a racialização gera uma valorização mercadológica, e é nesse contexto que Henrique se encontra, um homem moreno, musculoso, sedutor, 
jovem e capoeirista, que, para além das mulheres de Piscitelli, encanta os homens e, com isso, mantém seu sonho europeu vivo.

\section{Atravessamentos do desejo: prostituição masculina em Lisboa}

Segundo Henrique, os brasileiros eram bastante requisitados no mercado do sexo local. Isso acabou formando uma espécie de rede, que tinha em Jeferson um de seus elos, especialmente, para aqueles garotos vindos de Mato Grosso do Sul. Para estes, o caminho era, quase sempre, o mesmo: ajudavam nas rodas de capoeira, o que servia como um álibi público acerca de uma profissão "honesta". Os alunos pagavam uma taxa e isso era, depois, dividido em partes desiguais entre Jeferson (que ficava com o maior montante) e os demais instrutores.

Nosso interlocutor avalia que sua carreira na prostituição lisboeta teria sido impulsionada por apresentar alguns atrativos físicos que eram preciosos para alguns consumidores locais do sexo tarifado (Pocahy 2012): era másculo, jovem, não branco, malhado e bem dotado, atributos associados a uma ideia de masculinidade hegemônica (Kimmel 1998; Connell 2016). Alguns clientes de Jeferson foram sendo remanejados para Henrique, que em vista desta transferência, passou a pagar uma taxa a Jeferson. Segundo conta, o mais importante nesse campo seria a propaganda "à boca miúda", nosso popular "boca a boca". Clientes satisfeitos com o serviço o recomendam a amigos e conhecidos. Henrique diz que esta foi a forma como ele passou a ser conhecido no "rolê" e foi assim que passou a "ganhar fama".

Entretanto, o começo do trabalho em Lisboa contou com outra vez voltar à rua e à sauna. Na chegada a Lisboa, a Rua da Barroca e uma sauna do Bairro Alto foram dois locais visitados com alguma frequência. Ali fez alguns clientes e foi se inserindo em uma rede de sociabilidade que tinha o sexo entre homens como elemento disparador. Ele também utilizou os aplicativos. De início se anunciava mesmo como garoto de programa recém chegado do Brasil, ativo e bem dotado. Depois, passou a fazer uma propaganda mais discreta, menos ostensiva, apenas insinuando que era garoto de programa, a partir do símbolo de um diamante, algo que era recorrente entre outros homens que se prostituiam na cidade, vindos de outras nacionalidades.

Henrique comenta que quando chegou a Lisboa se cadastrou no VipHomens, cujo site é viphomens.net. Nele estão os perfis de muitos 
garotos de programa em diversas cidades portuguesas. O site define-se como um classificado online de anúncios de conteúdo erótico e é destinado exclusivamente ao público adulto, isto é, maiores de 18 anos. Trata-se de um veículo de comunicação que publica anúncios, mas não faz intermediação com os anunciantes. As informações contidas nos anúncios são de responsabilidade dos anunciantes. $O$ site é sediado na cidade do Porto, em Portugal. A grande maioria dos homens que se anuncia ali é composta por brasileiros.

À parte o gosto pelas ruas, Henrique contou que fazia "relativo sucesso" nas saunas da cidade, onde nunca foi permitido o exercício da prostituição de forma explícita, mas ela sempre ocorreu. Ele, como de costume, se insinuava para os homens mais afeminados, mais feios e mais velhos. Na visão do interlocutor, estes seriam os mais "frágeis, ninguém gosta deles. Mas eles geralmente têm "grana".

O primeiro ponto, observado por Henrique, é que a sauna tem "melhor nível". Isso se reflete a partir da necessidade do pagamento de um ingresso. Há um claro recorte de classe: quem não consegue pagar, não entra. Há uma seleção. Aqui, percebe-se uma associação entre classe e segurança, afinal é demasiado comum em nosso imaginário a aproximação de pobreza à violência. Outro ponto, a ser destacado, é a busca, mesmo na sauna, de certo grau de anonimato. Como aponta Normando José Queiroz Viana (2010), as saunas, mesmo em regiões centrais da cidade, costumam ser pouco sinalizadas e não há qualquer elemento que ligue a construção a um espaço de sexo entre homens. O elemento da discrição, como aponta Eder da Silva Deodato (2015) é fundamental. Nesse espaço discreto, limpo e seguro (Victor Hugo de Souza Barreto 2012), garotos de programa e, principalmente, clientes, estariam mais a vontade para os "jogos de sedução".

Para nosso interlocutor, o relativo sucesso dos brasileiros no mercado do sexo local, bem como a majoritária presença dos mesmos, se devia a uma série de fatores que constitui um imaginário sobre os brasileiros na economia sexual lisboeta e que eles utilizam em seus jogos de sedução. "Malandragem", "safadeza", "sexo sem restrições" foram expressões usadas para caracterizar esse encontro, que poderia ser, inclusive, acionado como uma memória colonial. Esse também faz parte do imaginário colonial português, quando das primeiras interações sexuais no Brasil, uma espécie de "libertinagem interracial" (Mbembe 2017), que reduzia o ser humano, 
como dissera Achille Mbembe (2017) sobre o processo em África, à aparência, pele e cor. Uma série de ilações do campo da cultura eram associadas à biologia.

A questão é que esta é uma permanência. Há uma sexualização dos corpos dos homens brasileiros a partir de um imaginário que os constroem como mais lascivos. Elementos de uma suposta cultura popular brasileira, como a "safadeza" e a "malandragem", são transpostos para o mundo do sexo e funcionariam como tensores libidinais que movimentariam, de forma muito particular, as economias sexuais, facilitando e não restringindo as interações. Dessa forma, como afirma Mbembe (2017) a ideia de raça, em contextos racializados, como o das economias sexuais por exemplo, constituem a raça como parte de uma bioeconomia.

Assim, Avtar Brah (2006) nos esclarece que, tal como Mbembe dissocia o "devir negro do mundo" de uma ascendência biológica, a antropóloga indiana compreende que as "pessoas de cor" não são assim classificadas a partir de sua cor de pele, mas, sobretudo, preponderantemente, a partir das relações subalternas que desenvolvem. A cor, na perspectiva de Brah, é política e não biológica. Nesse sentido, o contexto racializado no qual estão inseridos os corpos dos garotos de programa brasileiros é racializado não porque eles são negros, ou não brancos, mas também por isso, entre tantos outros marcadores que carregam e que os constituem como subalternos em uma economia mais ampla.

Como dissemos no começo, Portugal funcionaria como uma porta de entrada para os garotos de programa brasileiros se prostituírem na Europa. A partir de Portugal, no entanto, era dada a largada para o trânsito pelos diferentes países. Henrique e seus amigos passavam temporadas em diferentes cidades, especialmente, capitais ou cidades importantes de outros países do continente. Via de regra, a região por onde circulavam era a união européia, em vista da facilidade de acesso.

A dinâmica era mais ou menos essa: no verão eles estavam nas praias da Espanha, sobretudo Barcelona, pois, contam os interlocutores, "os gringos baixam todos pra lá e não economizam". Os "gringos", aqui, eram os europeus do norte do continente, com destaque para os escandinavos. Nos outros períodos do ano, eles acompanham o calendário de grandes eventos, bem como festas nacionais, festivais musicais, ou as paradas LGBT das diferentes capitais. Ou seja, estavam sempre atentos a épocas, momentos 
e eventos em que houvesse, potencialmente, a maior concentração de pessoas LGBT nas cidades. A circulação era uma espécie de credencial de uma "carreira de sucesso".

A ideia de "carreira de sucesso" precisa ser pensada com especial atenção. Ela passa, nos parece, invariavelmente, pelo fato de "ser brasileiro" e por tudo aquilo que está associado a uma brasilidade nas economias sexuais. Estamos falando, sim, de uma possível racialização do desejo. Um contexto racializado é muito mais do que um paradoxo branco e preto. Mas de uma escala, com uma imensa área cinza, que é exatamente a dimensão onde se produz o processo de racialização, em que os sujeitos são objetificados, os sujeitos são transformados em mercadoria, os sujeitos são moeda (Mbembe 2017).

Nesse sentido, este outro racializado é alguém sobre quem paira desconfiança, o espectro de perigoso, diferente, excluído, embrutecido, degradado. Ele, este outro, não precisa, necessariamente, ser preto, mas ele precisa, obrigatoriamente, ser parte de uma humanidade subalterna, que compõe o "devir negro do mundo" (Mbembe 2017). Portanto, desse sujeito racializado e constituído como nosso outro, é preciso defender-se, proteger-se, destruir. Isso tudo em tese. Na prática, em diferentes contextos, os processos são mais complexos, e essa "outridade" é que, justamente, pode servir como um estimulante do desejo.

Por outro lado, não estamos tentando construir, outra vez, uma escala branco e preto, em que uns são os exploradores e outros são os explorados. Pelo contrário. Nos parece interessante aqui pensar as áreas cinzas, onde as diferenças se confundem. Dimensões em que as fronteiras são borradas. Espaço onde as rupturas e permanências são constantes. Esses borrões, acreditamos, são os momentos, as brechas, as fissuras em que podemos falar de agência, sobretudo, dos garotos de programa, se os quisermos pensar como elos mais fracos desse gradiente.

Ao pensar a ideia de agência, precisamos fazer algumas ponderações. Há uma longa tradição de debates na antropologia sobre o tema. Mas, por questão de objetividade, vamos nos dedicar a pensá-la a partir de Sherry Ortner (2006). A agência depende do contexto em que os atores buscam, efetivamente, cumprir seus projetos estabelecidos. Concretizar projetos envolve estratégias, rotina, ações intencionais individuais e coletivas. Logo, a agência está em diálogo com uma ideia mais ampla de projeto, que se 
efetiva a partir de um determinado campo de possibilidades. A agência age nas brechas, nas fissuras, nas tensões dos jogos sérios, pois são variáveis. Agência provoca as imbricações. Isso se aplica muito à prostituição dos garotos com os homens mais velhos.

Evidente que estamos diante de relações de poder e agência, o que envolve poder, assimetrias e recursos. A partir de uma perspectiva foucaultiana, o que temos, mais que um-ganha-outro-perde, é uma tensão, uma disputa e aí, cada uma das frentes envolvidas no processo, barganha com aquilo que tem. Para Ortner, "onipresença do poder e da desigualdade na vida social é central para a própria definição de jogos sérios” (Ortner 2006, p. 46). Onde há poder, claro, há uma frente hegemônica, que não deve ser desconsiderada, mas há, sempre, possibilidades de resistência constituída pela agência dos sujeitos.

Os garotos desejam o dinheiro, que pode ser o passaporte para frequentar uma Europa, ainda desconhecida, mas já sedutora. Junto ao dinheiro, pode vir segurança, presentes, agrados, ajudas, inclusive afeto, em um contexto quase apenas permeado por desconhecidos. Clientes sabem barganhar com o que têm, dinheiro. Sem eles, os clientes, não há negócio. Por outro lado, os garotos também sabem usar muito bem o corpo que têm, a masculinidade que desenvolvem, a juventude que têm, bem como se apossar de um "imaginário racializado" a seu favor. Porque sabem como fazer para conseguir algumas vantagens nessa delicada relação. É nesse sentido que concordamos quando Foucault (1995) diz que o poder é relacional, ou seja, não pertence, ou é exercido apenas por uma das partes. Clientes ou garotos, ambos são sujeitos e permeiam suas práticas sociais de trabalho por relações de poder. 


\section{Considerações finais}

Ainda há muito a se investigar sobre a prostituição masculina no Brasil e em Portugal para conseguirmos respostas mais profundas sobre muitos dos temas explorados nesse texto. Temos nos aventurado nos primeiros passos ao longo dos últimos quatro anos. No entanto, as possibilidades, ainda em aberto, são consideráveis. Recém nos acercamos de um ponto de uma suposta rota de migrantes brasileiros para Portugal que teria como elemento disparador o uso tarifado do corpo em terras lusitanas. Outros pontos, quem sabe, podem nos levar a conhecer outras diferentes estratégias deste seguimento das economias sexuais em contextos transnacionais.

Aqui, por enquanto, conseguimos nos deter nas estratégias de dois sujeitos que partiram de Mato Grosso do Sul para Lisboa na expectativa de aprofundar experiências bastante incipientes no mercado do sexo local. Observamos, a partir de um interlocutor-chave, como a prostituição foi delineando curvas de vida que resultaram na metamorfose de um projeto que parecia bastante consolidado na cidade de origem e deu início a uma nova carreira, quem sabe de sucesso, no campo das economias sexuais em contextos transnacionais. Além de sedutora, porque repleta de novidades, a prostituição masculina, para nosso interlocutor, aparece como desafiadora diante de uma realidade "morna". A prostituição como tempero e sedução parece ter sido o novo e vasto campo de possibilidades apresentado a ele, bem como a seus conterrâneos.

A ideia de novidade rondou os primeiros tempos em Portugal e tem sido uma constante no mercado erótico lisboeta. É preciso sempre ser novidade. Para tanto, a ideia de trânsito, de circulação, de reinvenção, de perambulação pelos diferentes equipamentos urbanos, pelas diferentes urbanidades, pelos diferentes países, é fundamental. Pois, ainda que o mesmo sujeito, por aportar em um lugar diferente, se é diferente. Ou seja, se é novidade. A sedução e o desafio do novo e do ser novo dá-nos a impressão de operar como uma espécie de tensor libidinal. É como se o novo valorasse 
o "produto" garoto de programa, pois quem o acessar o estaria fazendo pela primeira vez.

O novo projeto, da prostituição masculina no exterior, e de sua circulação por outros países, para além de Portugal, não é apenas uma constante de facilidades. Como mostramos, há desafios, há mudanças, há reveses. A construção de uma rede de solidariedade, talvez, seja o mais emblemático deles, pois a distância da família, dos amigos e de tudo que confere algum grau de identificação pode até ser encantador em um primeiro momento, mas, como nos contaram, gera uma sensação de falta depois de passada a "euforia dos primeiros tempos".

Ainda recorre um imaginário que naturaliza uma certa brasilidade como lasciva, malemolente em vista de aspectos ligados à geografia, por exemplo. Nesse imaginário, "malandragem”, "safadeza”, "fogo”, "malícia” seriam características "naturais" dos brasileiros. Esses atributos seriam, portanto, elementos que, nas economias sexuais, precificariam os serviços prestados pelos brasileiros e seriam, altamente, valorizados no mercado lusitano e, quem sabe, europeu. Há, nisso que apresentamos, uma racialização do desejo dos sujeitos e dos corpos brasileiros.

Talvez, segundo nossas observações, haja uma dimensão de agência por onde os nossos interlocutores se movem. Os movimentos da agência destes homens é que dinamiza e turva um pouco as esperadas relações de poder entre quem tem dinheiro de um lado e quem tem um corpo jovem, musculoso e não branco de outro. Há, sim, até onde conseguimos ir nessa etapa da pesquisa, outros fatores em jogo.

Uns e outros, clientes e garotos, transitam por suas arenas seguras e tensionam até um limite que eles consideram prudente na intenção de fazer com que o desejo fique, cada vez mais, aguçado. Talvez aí, a brasilidade hiperssexualizada e "safada" ganhe destaque, pois seria "característico" do brasileiro esse tempeiro "maldoso" que assombra, mas, ao mesmo tempo, "hipnotiza" os "gringos" tão literais. Se, de um lado, há o lúdico da fantasia do brasileiro macho e ativo sexualmente; do outro lado, há uma dimensão também fantasiosa do gringo velho, endinheirado e ingênuo. Esses dois opostos, modelos ideais, são apenas dois polos de um gradiente que oferece muitas possibilidades. Uns e outros, entendemos, jogam com esses lugares comuns a eles associados no sentido de potencializar o desejo e extravazar os prazeres impublicáveis e moralmente, ainda, inclassificáveis. 


\section{REFERÊNCIAS}

ALMEIDA, Mateus Fernandes de Oliveira. Representações do associativismo entre as mutuais de trabalhadores na Corte do Império. Estudos Ibero-Americanos, 41: 143-163, 2015.

ANDRADE, Bruno Amaral. Configurações lusófonas: uma peculiar lusofonia a partir da internacionalização da capoeira, do seu conteúdo cultural e da especificidade do uso da língua portuguesa. Revista Angolana de Sociologia, 10; 149-161, 2012.

BARRETO, Victor Hugo de Souza. “Vamos fazer uma sacanagem gostosa?”: Uma etnografia do desejo e das práticas da prostituição masculina carioca. Niterói, Universidade Federal Fluminense, 2012.

BRAGA, Gibran T. “Não sou nem curto": Prazer e conflito no universo do homoerotismo virtual. Rio de Janeiro, Universidade Federal do Rio de Janeiro, 2013.

BRAH, Avtar. Diferença, diversidade, diferenciação. Cadernos Pagu, 26: 329-376, 2006.

BRITO, Celso de. Eu sou angoleiro, um estilo mandingueiro de masculinidade: capoeira, gênero e corporalidade, Boitatá, 4: 01-26, 2007.

CONNELL, Raewyn. Gênero em termos reais. São Paulo, nVersos, 2016.

DEODATO, Eder da Silva. Performance e identidade de gênero na prostituição masculina em saunas gays. Recife, Universidade Federal de Pernambuco, 2015.

FOUCAULT, Michel. O sujeito e o poder. In: DREYFUS, Hubert, RABINOW, Paul. M. Foucault: uma trajetória filosófica para além do estruturalismo e da hermenêutica. Rio de Janeiro, Forense Universitária, 231-249, 1995.

GREGORI, Maria Filomena. Prazeres perigosos: Erotismo, gênero e limites da sexualidade. São Paulo, Companhia das Letras, 2016.

KIMMEL, Michael S. A produção simultânea de masculinidades hegemônicas e subalternas. Horizontes Antropológicos/UFRGS, Porto Alegre, 1998.

MBEMBE, Achille. Crítica da razão negra. Lisboa, Antígona, 2017.

MISKOLCI, Richard. O armário ampliado: notas sobre sociabilidade homoerótica na era da internet. Gênero, 9: 171-190, 2009.

MISKOLCI, Richard. Machos e Brothers: uma etnografia sobre o armário em relações homoeróticas masculinas criadas on-line. Revista Estudos Feministas, 21: 301-324, 2013.

ORTNER, Sherry. Poder e projetos: reflexões sobre a agência. In: GROSSI, Miriam Pillar; ECKERT, Cornelia, FRY, Peter Henry (eds.). Conferências e diálogos: saberes e práticas antropológicas. Goiânia, Nova Letra, 2006.

PASSAMANI, Guilherme R. Batalha de Confete: envelhecimento, condutas homossexuais e regimes de visibilidade no Pantanal-MS. Rio de Janeiro: Papéis Selvagens, 2018. 
PASSAMANI, Guilherme Rodrigues; ROSA, Marcelo Victor da; LOPES, Tatiana Bezerra de Oliveira. Sutilezas e 'escadas da moralidade' nas saunas de Campo Grande-MS. Revista Estudos Feministas, Florianópolis, v. 28, n. 1, 2020.

PELÚCIO, Larissa. Desejos, brasilidades e segredos: o negócio do sexo na relação entre clientela espanhola e travestis brasileiras. Bagoas, 10: 243-266, 2011.

PERLONGHER, Néstor. O negócio do michê: A prostituição viril, São Paulo: Brasiliense, 1987.

PISCITELLI, Adriana Gracia. Trânsitos: brasileiras nos mercados transnacionais do sexo. Rio de Janeiro: EDUERJ/ Clam, 2013.

PISCITELLI, Adriana. "Gringas ricas": Viagens sexuais de mulheres europeias no Nordeste do Brasil. Revista de Antropologia. São Paulo, 53, (1): 79-115, 2010.

POCAHY, Fernando Altair (2012), “Vem meu menino, deixa eu causar inveja”: ressignificações de si nas transas do sexo tarifado. Sexualidad, Salud y Sociedad, Revista Latinoamericana, 11: 122-154, 2012.

PRADO FILHO, Kleber. Estetização da subjetividade: Formas contemporâneas de cuidado e produção de si mesmo. Cadernos Discursivos, Catalão, 2 (1): 92-103, 2018.

SANTOS, Harriet Karolina Galdino dos, APOLINÁRIO, Juciene Ricarte. Relações de gênero e violência na Campina Grande Imperial. Mnemosine, Rio de Janeiro, 1(2): 84-103, 2010.

SCHEIN, E. H. Career anchors: discovering your real values. Sydney: Pfeiffer and Company, 1993.

SCHÜTZ, Alfred. Collected Papers I: The Problem of Social Reality, Norwell, Kluwer Academic Publishers, 1974.

SILVA, Ana Paula da. Trabalho sexual: entre a conquista de direitos e o processo de vitimização, Novos Debates, 2: 223-232, 2015.

SILVA, Ana Paula, BLANCHETTE, Thaddeus. Nossa Senhora da Help": sexo, turismo e deslocamento transnacional em Copacabana. Cadernos Pagu, 25: 249-280, 2005.

SIMÕES, Julio Assis. Homossexualidade masculina e curso da vida: pensando idades e identidades sexuais. In: PISCITELLI, Adriana, GREGORI, Maria Filomena, Carrara, Sérgio (eds.). Sexualidade e saberes: convenções e fronteiras. Rio de Janeiro, Garamond, 2004.

VELHO, Gilberto. Projeto e metamorfose: antropologia das sociedades complexas. Rio de Janeiro, Jorge Zahar Editor, 1994.

VIANA, Normando José Queiroz. "É tudo psicológico dinheiro... pruuu! fica logo duro": desejo, excitação e prazer entre boys de programa com práticas homossexuais em Recife, Recife, Universidade Federal de Pernambuco, Recife, 2010. 


\title{
O FUNK CARIOCA E O DOM DE VISIBILIZAR CULTURAS E IDENTIDADES: QUANDO A REPRESENTATIVIDADE TRANSFORMA O SOCIAL (?)
}

\author{
Benjamin Braga Neves
}

\begin{abstract}
O direito é importante, mas tem impacto muito limitado na cultura de gênero. Mudar instituições não é só mudar regras - tem que mudar pessoas também. E mudar pessoas é um processo demorado e inclui disputas de diversas forças.
\end{abstract}

(Neves,B.; Noronha, J., 2018)

De acordo com Chauí (2008, p.01), a definição do conceito de cultura sofreu diversas modificações nos séculos XVIII, XIX e XX e neste último, a autora nos afirma que:

Sea por tener una formación marxista, sea por tener un profundo sentimiento de culpa, buscarán deshacer la ideología etnocéntrica e imperialista de la cultura, inaugurando la antropología social y la antropología política, en las cuales cada cultura expresa, de manera históricamente determinada y materialmente determinada, el orden humano simbólico con una individualidad propia o una estructura propia. A partir de entonces, el término cultura pasa a tener un alcance que no poseía antes, siendo ahora entendido como producción y creación del lenguaje, de la religión, de la sexualidad, de los instrumentos y de las formas del trabajo, etc.

Desta maneira, é possível notar que há uma ampliação do conceito de cultura, e este pode envolver diversos processos ou sistemas, como o de produção e criação de linguagem, da religião, etc e o que mais me interessa investigar neste trabalho: o da sexualidade. 
Chauí (2008) nos afirma ainda, que a indústria cultural vende cultura e para a filósofa, isto significa que:

Ela deve agradar e seduzir o/a consumidorx. Para seduzí -lx e agradá-lx, não pode causá-lx desgosto, provocá-lx, fazê-lx pensar, levar informações novas que não o/a perturbem, e sim devolver a ele/ela algo com uma nova roupagem, o que ele/ela ajá viu, riu sobre ou conhece. A ' 'média' ' é o sentido comum cristalizado que a indústria cultural devolve com cara de novo. (Chauí, 2008, p., tradução minha)

Diante da afirmativa acima, é interessante percebermos o potencial que o funk, em especial o funk produzido no Estado do Rio de Janeiro, teve e ainda tem em provocar mudanças sociais e culturais. De fazer o som de pretx, de faveladx, de bicha louca e estranha e de travestisgêneres (Siqueira, 2015), provocar movimentos. Ainda que uma grande parte dos funks produzidos nas últimas décadas reproduzam culturas de classe, e gênero cisbrancoheterocentradas, por exemplo, o funk segue sendo vanguardista, especialmente na última década.

As produções de Tati Quebra Barraco, mulher negra, obesa e favelada, de Linn da Quebrada, pessoa trans, negra e periférica e de Kaique Theodoro, homem trans ${ }^{157}$ jovem e morador da zona oeste do Rio de Janeiro, são exemplos de artistas, repertórios e imagens que nos propõem uma outra geografía da proximidade humana (Baptista, 2005), uma estética da experiência e não somente da informação.

Eu poderia explorar e analisar algunas das canções $d x$ s artistas acima mencionados. No entanto, para este ensaio, me proponho a analisar a

\footnotetext{
${ }^{57}$ Em dezembro de 2014, dezessete homens trans brasileiros, sendo eu um destes, participaram do IX Encontro Regional Sudeste de Travestis e Transexuais, evento organizado pelo Fórum Paulista de Travestis e Transexuais. Neste encontro foi decidido e aprovado em plenária, que a partir da data onde foi votada a decisão, a identidade política dos homens trans brasileiros seria nominada como homens trans e o movimento de pessoas trans do Encontro Regional Sudeste, concordou que este passaria a se chamar de movimento de travestis, mulheres transexuais e homens trans. É válido mencionar que diferentemente do movimento de travestis e de mulheres transexuais, o nosso movimento, o movimento de homens trans, vem se organizando de maneira distinta e o termo homens trans, engloba uma diversidade de homens trans. Existem homens trans intersexuais, transgentes masculinos, transgêneros masculinos, trans homens, homens trans, ftms, homens e pessoas não binárias que se identificam com as transmasculinidades ou com as diferentes construções de masculinidades.
} 
canção e vídeoclipe Dom, de Kaique Theodoro, sob a luz dos conceitos do transfeminismo das transmasculinidades (Neves; Palhano \& Peçanha, 2015) e da geografia da proximidade humana (Baptista, 2005), comparando-o a duas outras produções da Kondzilla: Me Solta (Nego do Borel) e O Grave Bater (Mc Kevinho).

É possível perceber um crescimento desenfreado das formas de biopolíticas de controle social, na denúncia da violência das formas de exclusão e estigmatização que dominam no mundo de hoje. Há forças Estatais e institucionais que (re) implantam regimes de verdade como naturais, absolutos e universais.

Por outro lado, existem outras forças que paralelamente a essas e impulsionadas por uma vontade de superação, tensionam o que se tem como dado e investem na elaboração de formas não-fascistas de pensamento e de vida.

Segundo Gondra (2009), Foucault descreve o poder a partir de três eixos: o poder disciplinar implica uma apropriação total ou tende a ser uma apropriação exaustiva do corpo, dos gestos, do tempo, do comportamento do indivíduo; o poder disciplinar é isotópico ou tende à isotopia, cada elemento tem seu lugar bem determinado; como as patentes no exército e a nítida distinção entre as diferentes classes de idade e, nas diferentes classes de idade, a posição de cada um na classe das escolas, por exemplo. O curso de 1973-1974 alerta para uma espécie de propriedade do poder disciplinar: uma certa relação com o corpo, gestos, tempo e comportamento do indivíduo e seu caráter contínuo e isotópico.

Tendo em vista esses apontamentos, é importante destacar que somos o que experimentamos ou imaginamos ao longo de nossas vidas. Nossos modos de existência são construídos todos os dias. A presença e o convívio entre nossos familiares na infância, o/a professor/a na escola, a pedalada sem rodinhas, o primeiro e o último beijo dado, aquela viagem dos sonhos, o primeiro emprego, o/a último/a chefe, o mercado da esquina e seus/ suas funcionários/as, um livro marcante. Todas essas pessoas, situações e relações intrínsecas contribuem todos os dias para nossas reflexões, questionamentos, aprendizagem e desenvolvimento pessoal.

As palavras masculinidade e feminilidade sempre chamaram a minha atenção. Estas palavras engendram imagens claras de dois sets opostos de comportamento e atributos pessoais. De alguma maneira, todos nós sabemos 
que características são estas. Na verdade, um dos mais impressionantes aspectos destas imagens é a extensão que nós ocidentais as dividimos.

Homens devem ser fortes, racionais, agressivos; mulheres devem ser fracas, emocionais e submissas. Ao mesmo tempo, de que maneira estas imagens cabem ou servem a maioria das pessoas na vida real? Homens e mulheres realmente se encaixam nestas imagens, ou estas imagens são estereótipos? Se homens e mulheres não se encaixam nestes estereótipos, como é que eles existem? Uma vez estabelecidos, de que maneira estes estereótipos afetam homens e mulheres em nossa sociedade? Uma vez afetado por estes estereótipos, como se libertar deles e se movimentar para além deles?

Existe pouca evidência fisiológica ou psicológica para apoiar os estereótipos de gênero como distinções entre os sexos. Todavia, os estereótipos são firmemente enraizados nas nossas psiques individuais e culturais, e são passados para as gerações futuras, direta e indiretamente via cada agente social de nossa sociedade (pais, professores, mídia e a religião, por exemplo). Os efeitos destes estereótipos são intensos e prejudiciais a todos os indivíduos (homens e mulheres), seus relacionamentos, e para a sociedade como um todo.

Os estudos queer apontam o gênero como um exercício de poder sobre os corpos, logo, há uma possibilidade de deslocamentos de gêneros, onde o resistir à normalização dos corpos de "dentro" do discurso de gênero, produz outros corpos e não apenas o masculino e o feminino da heteronormatividade. Nesta ótica, podemos pensar e praticar não apenas um binarismo de gênero, como o discurso da heteronormatividade postula, mas também uma proliferação e dispersão de gêneros, uma euforia de gêneros, como nos propôs Lima em seu manifesto intitulado Por uma Euforia de Gêneros (2014). Portanto, as problemáticas das minorias sexuais são antes de tudo questões de gênero.

Se o caráter imutável do sexo é contestável, talvez o próprio "sexo" seja tão culturalmente construído quanto o gênero, de tal forma que a distinção entre sexo e gênero se revela nenhuma: 
Se o sexo é, ele próprio, uma categoria tomada em seu gênero, não faz sentido definir o gênero como a interpretação cultural do sexo. [...] Resulta daí que o gênero não está para cultura como o sexo está para a natureza; ele também é o meio discursivo/cultural pela qual 'a natureza sexuada' ou 'um sexo natural' é produzido e estabelecido como 'pré-discursivo', anterior à cultura, uma superfície politicamente neutra sobre a qual age a cultura. (BUTLER, 2008, p. 25)

Logo, o binarismo sexual homem-mulher seria uma das infindas possibilidades de práticas de gênero. Sexo seria uma performance de gênero, dentre várias possíveis. Butler lança mão do conceito de performatividade, para desconstruir a noção naturalizada de gênero ou de identidade sexual. Performatividade seria o "poder reiterativo do discurso, para produzir os fenômenos que ele regula e constrange" (BUTLER, 2001, p.155). Ou seja, os discursos heteronormativos - e na perspectiva queer, todos os saberes institucionalizados no Ocidente são cisheteronormativos: psicologia, psicanálise, saberes médicos, ciências sociais, pedagogia, etc. - agem como se apenas analisassem "dados" anteriores aos discursos, como a identidade sexual dos sujeitos. Mas, na verdade, os discursos heteronormativos criam estes "dados"; os discursos produzem sujeitos com identidades heterossexuais através de uma constante reiteração, que começa desde o nascimento dos indivíduos e os acompanha até o final de suas trajetórias de vidas.

Como podemos perceber, o conceito de gênero, reelaborado e distante de noções essencialistas e naturalizantes, é fundamental, do ponto de vista queer, para se analisar tanto o poder normalizador - produtor voraz de corpos masculinos ou femininos, corpos coerentes e inteligíveis, daí a intervenção médica no corpo intersexual ou no corpo transexual, que devem ser ou masculinos ou femininos, não havendo lugar para ambiguidades - quanto para a produção de resistência de minorias sexuais, que procuram elaborar performances de gênero em seus corpos que são ininteligíveis para norma heterossexual; são performances do estranho, do abjeto, portanto, queer.

Retomando a canção e videoclipe que me propus analisar, Dom, de Kaique Theodoro, em entrevista concedida ao Nlucon, o funkeiro e homem trans carioca, comenta sobre a sua nova canção de trabalho, e nos revela: 
Quis brincar com e questionar o conceito de grandes produtoras de funk, que sempre colocam o artista em primeiro plano e as bailarinas como pano de fundo ou objeto de cena. Quis que todos tivessem seu momento de glamour, até porque só participou gente maravilhosa.

Além de nos apresentar outra perspectiva de enquadramento de pessoas (artistas, bailarinxs, figurantes) versus artista principal, - eu arriscaria dizer que Theodoro trabalhou aqui à luz do conceito do transfeminismo das transmasculinidades ${ }^{58}$ - a produção de Theodoro também nos propõe uma transformação cultural e social. Ao contratar e contar com a ajuda de amigues travestigêneres para a construção do clipe, e trabalhar em todas as outras funções de finalização dele sozinho, ele nos coloca/provoca outras questões como: baixa empregabilidade de pessoas/artistas trans no mercado cisbrancoheteronormativo. Normalmente, se contratam artistas cisgêneros para as mais diversas funções. Um exemplo bastante marcante, para nós homens trans, foi o da contratação de uma atriz cisgênera escolhida para representar o primeiro personagem homem trans a fazer parte de uma telenovela brasileira, o Ivan da telenovela Global Força do Querer, escrita por Glória Peres no ano de 2017. Não há problemas em uma pessoa cis representar uma pessoa trans, o problema está no fato de atores e atrizes trans sempre serem preteridxs por artistas cisgêneros para todo e qualquer papel.

Visibilidade e protagonismo no beijo lésbico negro, raramente vistos em videoclipes de grandes produtoras de funk e identidades, sexualidades e corpos ressignificados ${ }^{59}$ : zoom na cena em que o homem trans, tido no

${ }^{58} \mathrm{O}$ transfeminismo do Sul (CONNEL, 2016), mais especificamente brasileiro, não contempla algumas especificidades do transfeminismo das transmasculinidades, como a negra, por exemplo. No intuito de sairmos da zona da invisibilização, eu e alguns outros ativistas transmasculinos brasileiros, com as mais diversas características, temos desejado marcar e ocupar esse espaço, pois temos muito a contribuir para a discussão e para a desconstrução do racismo estrutural de nosso país. Para maiores informações sobre Transfeminismo Negro das Transmasculinidades, ver http://negrosblogueiros.com.br/

${ }^{59}$ Vale destacar que a Kondzilla (www.kondizilla.com) uma das maiores produtoras de artistas e videoclipes de funk brasileiro, raramente cria e divulga materiais distantes da lógica ciscentrada, com exceção do videoclipe e canção do artista Nego do Borel, em 'Me solta' (https://www.youtube. com/watch?v=FY3m6hMyh3g), do ano de 2018. Todavia, este videoclipe foi muito problematizado na época de seu lançamento e Nego do Borel foi acusado, entre diversas coisas, de ser oportunista e se "travestir e beijar um outro homem, cisgênero, branco e sarado", apenas para se recolocar no mercado novamente. 
imaginário cultural e social da cisheteronorma como um homem que reproduz uma masculinidade sem pênis ${ }^{60}$, sarrando a raba de uma mulher trans/travesti.

Como já mencionado anteriormente, homens trans é o termo político adotado para se demandar políticas públicas em saúde específicas, por exemplo. Todavia, existe uma infinidade de categorias identitárias que são incluídas nesta categoria política, inclusive a de pessoas não binárias, ou seja, pessoas que não se identificam, exclusivamente, nem como homens ou como mulheres.

Theodoro, assim como diversos homens trans, faz reposição hormonal com testosterona (hormônio masculino), que dá características secundárias masculinas ao corpo da pessoa transmasculina. No entanto, a leitura social de homem cisgênero que a testosterona dá a diversos homens trans, incluindo a do cantor em questão, acaba por apagar as demais categorias identitárias e principalmente, a sexualidade ou a não existência de sexualidade nestas pessoas.

A seguir, proponho um quadro de análise das três produções, onde foram observados e considerados os seguintes aspectos: corpos presentes (que tipos de corpos?), técnicas de destaque ou contraposição do artista em tela, produção independente $x$ grande produtora, empregabilidade de pessoas Igbtiq+, se há ou não evidências de outras formas de se estar no mundo, por exemplo, como uma proposta de reflexão da invisibilidade transmasculina e de que o mercado do funk mainstream nacional, se alimenta.

\footnotetext{
${ }^{60}$ Acredito que a autora tenha deixado de fora um ponto: nem todos os homens trans produzem uma masculinidade sem pênis. Alguns homens têm orgulho e fazem bom uso de suas vaginas, inclusive fazendo uso político dela também, todavia, outros recorrem a diversas tecnologias, incluindo aí as cirúrgicas e ganham ou têm seus pênis reconstruídos, moldados e mesmo assim, esses homens podem continuar a desestabilizar o cistema (Neves, 2015). Não é a presença ou ausência de um pênis, seja ele um pênis trans ou um que se assemelhe a um pênis de um homem cisgênero que tornam os homens trans, os homens que são, ou que lhes dão a capacidade de transformar ou quebrar essa masculinidade hegemônica. O que pode causar essa ruptura são as atitudes deles ou como esse "novo" gênero é representado.
} 


\begin{tabular}{|c|c|c|}
\hline Kaique (Dom) & Nego do Borel (Me Solta) & Mc Kevinho (O Grave) \\
\hline $\begin{array}{l}\text { Corpos não normativos e } \\
\text { diversos corpos negros }\end{array}$ & $\begin{array}{l}\text { Corpos não normativos e } \\
\text { presença de corpos negros }\end{array}$ & $\begin{array}{c}\text { Corpos normativos e } \\
\text { binaristas }\end{array}$ \\
\hline $\begin{array}{l}\text { Artista principal de } \\
\text { pano de fundo, dando } \\
\text { visibilidade a outros } \\
\text { corpos }\end{array}$ & $\begin{array}{c}\text { Artista principal em } \\
\text { evidência }\end{array}$ & $\begin{array}{l}\text { Artista principal em } \\
\text { evidência }\end{array}$ \\
\hline $\begin{array}{l}\text { Produzido de forma } \\
\text { independente }\end{array}$ & $\begin{array}{l}\text { Produzido pela Kondzilla, } \\
\text { famosa produtora de hits } \\
\text { nacionais }\end{array}$ & $\begin{array}{l}\text { Produzido pela Kondzilla, } \\
\text { famosa produtora de hits } \\
\text { nacionais }\end{array}$ \\
\hline $\begin{array}{c}\text { Contou com a colaboração } \\
\text { de diversas pessoas trans } \\
\text { e travestis (confirmando } \\
\text { que oportunidade e } \\
\text { empregabilidade, quase } \\
\text { sempre, estão alinhadas) }\end{array}$ & $\begin{array}{c}\text { Contou com pessoas que já } \\
\text { trabalham como figurantes } \\
\text { e/ou dançarinos (as) }\end{array}$ & $\begin{array}{c}\text { Contou com pessoas que já } \\
\text { trabalham como figurantes } \\
\text { e/ou dançarinos (as) }\end{array}$ \\
\hline $\begin{array}{l}\text { Evidencia outras formas } \\
\text { de se estar no mundo, a } \\
\text { quem se pode amar e que } \\
\text { não se precisa de gênero } \\
\text { ou corpo específico para se } \\
\text { expressar o afeto, o desejo }\end{array}$ & $\begin{array}{l}\text { Foi apontado e bastante } \\
\text { criticado por tentativa } \\
\text { de se apropriar de uma } \\
\text { cultura que não é a } \\
\text { sua, evidenciando uma } \\
\text { relação supostamente } \\
\text { homoafetiva, mas } \\
\text { apenas para obter maior } \\
\text { popularidade, através do } \\
\text { polêmico beijo. }\end{array}$ & $\begin{array}{l}\text { Evidencia formas já } \\
\text { esperadas de se estar no } \\
\text { mundo. Não há outras } \\
\text { representações de corpos } \\
\text { ou de expressões de } \\
\text { gênero para além da } \\
\text { cisheteronormatividade }\end{array}$ \\
\hline
\end{tabular}

De acordo com Neves (2015), a masculinidade não é um privilégio exclusivo dos homens. Existem meninas masculinas, assim como mulheres masculinas ou masculinizadas. Infelizmente, na nossa sociedade ocidental, as mulheres masculinas são ainda muito estigmatizadas e invisibilizadas. As subjetividades femininas e lésbicas são infindas e nos levam a refletir sobre os próprios gêneros lésbicos.

O autor norte-americano Jack Halberstam em sua obra intitulada Female Masculinity (1998) nos mostra que mesmo não tendo uma resposta exata quando perguntado o que era a masculinidade, faz-nos algumas propostas sobre o motivo pelo qual a masculinidade não deve e não pode ser reduzida ao corpo masculino e aos seus efeitos. Ao mesmo tempo em que temos dificuldades em definir esse termo, temos bem pouca em reconhecê-lo. 
A masculinidade em nossa sociedade agrega noções de poder, legitimidade e privilégio. Halberstam, ainda no início de sua obra, já citada acima, mostra-nos que a masculinidade feminina pode ser notada em diversos filmes, inclusive em Goldeneye (1995). Nessa película, o chefe de James Bond é uma caminhoneira mais velha que faz várias piadas e que acusa Bond de ser sexista e misógino. A masculinidade nesse filme é prostética e tanto em Goldeneye como em outros, percebemos que a masculinidade pouco tem a ver com hombridade biológica, mas sim como um efeito técnico especial. A chefe é a pessoa que mais convincentemente nos presenteia com uma performance masculina. Ela nos convence de que a misoginia e o sexismo não são, necessariamente, parte ou parcela da masculinidade (Neves, 2015).

Várias questões acerca da transexualidade vêm sendo levantadas, especialmente, na última década. Existem poucos estudos sobre as experiências e o que se compreende entre os espaços divididos entre lésbicas masculinizadas (butches ou "caminhoneiras"), mulheres masculinas, homens trans, pessoas transmasculinas e a definição de gênero ou expressão de gênero para cada um desses indivíduos.

A masculinidade feminina muitas vezes está ligada à homossexualidade feminina. Todavia, é importante pontuar que nem toda lésbica é masculinizada e que nem toda mulher masculinizada é, por sua vez, lésbica. Existem várias atletas olímpicas, por exemplo, que possuem uma estética corporal e/ou um comportamento masculino, mas que têm como orientação sexual a bissexualidade ou a heterossexualidade. Embora algumas poucas mulheres masculinas tenham conseguido aparecer na grande mídia e/ou serem identificadas como personalidades de sucesso, ainda não há uma aceitabilidade ou reconhecimento dessas masculinidades.

Nos últimos quarenta anos, as descrições médicas acerca da transexualidade parecem ainda estar mais preocupadas com o discurso " nasceu no corpo errado" e em descrever a construção social dos corpos trans como um "erro da natureza", deixando de lado outras questões, não menos importantes obviamente, como as que tangem a identidade de gênero e o sexo biológico.

Devido a um maior avanço em algumas técnicas específicas envolvendo procedimentos cirúrgicos realizados em homens trans, a visibilidade dos transexuais masculinos, a partir dos anos 90, parece ter complicado as 
discussões acerca da transexualidade, uma vez que expôs aos olhos da sociedade elementos que, até então, viviam à sombra da dicotomia na categorização de gênero.

No livro intitulado Female Masculinity, Jack Halberstam (1998) dedica um capítulo inteiro para discutir a suposta fronteira de guerra entre butches (caminhoneiras) e homens trans, e questiona:

Se algumas pessoas, nascidas com o sexo feminino, agora demonstram um claro desejo de tornarem-se homens, qual é o efeito dessas transições sobre a masculinidade do homem do sexo masculino e na categoria da butch? Qual será o efeito de uma população transexual visível perante jovens que se identificam como aqueles que "brincam de cruzar fronteiras"? De que maneira, ao remover-se o estigma que recai sobre a categoria, mais tomboys anunciariam suas aspirações transexuais? (HALBERSTAM, 1998, p.142, tradução minha)

Existe no autor uma preocupação acerca de uma maior visibilidade dos homens trans e as consequências dos efeitos dessa visibilidade sobre diversas outras categorias, como a das caminhoneiras, por exemplo. À medida que a tecnologia médica se torna mais acessível e, consequentemente, a possibilidade de transicionar também, ele questiona que outras 'mulheres' poderiam querer fazê-la. Ainda segundo Halberstam, não se pode descartar também os efeitos da visibilidade dos homens trans sobre a masculinidade dos homens cisgêneros.

Para Halberstam (1998), a transição do gênero feminino para o masculino permite com que pessoas registradas como do sexo feminino ao nascer, tenham acesso, entre outras possibilidades, a privilégios como salários mais altos e colocações profissionais de maior prestígio. Em se tratando de hierarquias de gênero, não se pode descartar a ideia de que a transição possa ser uma solução à mobilidade social para 'algumas mulheres'.

É preciso cuidado ao mencionarmos essa hipótese, pois em se tratando de um assunto tão delicado quanto à transexualidade, precisamos levar em consideração os sentimentos, as angústias e principalmente, as inúmeras características que se interseccionam com relação a essas pessoas e que podem fazê-las sofrerem mais ou menos discriminações e constrangimentos ao longo de suas vidas. É preciso compreender que para muitos transexuais, a decisão pela cirurgia não só os transforma ou lhes dá acesso a outras 
oportunidades, mas também, na maioria das vezes, lhes traz de volta a vontade de viver.

Nem todos os transgêneros que experimentam a "disforia de gênero" lidam com ela da mesma forma. Nem todas as pessoas trans tomam hormônios e nem todas aquelas que tomam hormônios podem ser consideradas transgêneros. Algumas pessoas se identificam como homens e "passam" perfeitamente, ou seja, são vistas pelas pessoas cisgêneras como homens, sem utilizarem recursos de modificações corporais mais radicais.

Em alguns países, existe uma forte tensão entre algumas lésbicas feministas e homens trans. Essas mulheres acusam os homens trans binários ou não binários, de terem sucumbido à heteronormatividade e aos papéis de gênero, ao invés de continuarem lutando ao lado delas, para combatê-los. Alguns homens trans, por sua vez, acusam essas mesmas mulheres de serem transfóbicas e ainda, apontam que muitas delas têm o mesmo desejo, mas que por medo, não transicionam.

Jeffreys (2002) aponta que por volta da década de 1970, quando as lésbicas feministas tomaram conhecimento acerca da transexualidade, notaram que a maior parte das cirurgias de redesignação sexual eram realizadas em homens. Naquela época, quatro vezes mais homens que mulheres recorriam à cirurgia. A transexualidade foi analisada como uma forma de controle social no sentido que "gentilmente oferecia" ao indivíduo "diferente" a alternativa de se readequar ao padrão binário e ter uma vida saudável. Até então, essas poucas cirurgias não causavam nenhum tipo de abalo na comunidade lésbica (Neves, 2015).

No final da década de 1980 e início de 1990, a configuração se transformou e muitas lésbicas fizeram a cirurgia de redesignação de sexo. Esse número vem aumentando e rapidamente. Na opinião de Jeffreys (2002), os homens trans estão destruindo o lesbianismo, pois ao optarem por fazer a transição, escapam da opressão social da qual ainda vivem milhares de mulheres e lésbicas no mundo e deixam de contribuir para a existência de uma sociedade livre de estereótipos de gênero e de privilégios pré-concedidos. Qual a razão para tanto sofrimento, gastos e mutilações para uma transição que atende somente ao indivíduo? Não seria mais fácil lutar por uma mudança nas relações de poder e da hegemonia masculina em nossa sociedade? 
Um tanto quanto intrigante, é saber que muitos homens trans, em algum momento ou em boa parte de suas vidas, "saem do armário" e vivem como lésbicas antes mesmo de se "assumirem" como homens trans. Todavia, é válido mencionar que muitos outros não o fazem. Por essa razão, é que não se pode afirmar exatamente o que distingue as lésbicas dos homens trans. Muitos transgêneros, possivelmente em algum momento, também se identificaram como butches em uma comunidade lésbica, mas desejam ou gostariam de poder manter os laços com a mesma.

Por outro lado, diversos homens trans já revelaram nunca terem se identificado enquanto lésbicas e muitos optaram/optam por não se relacionarem com ninguém, até conseguirem acessar as modificações que desejam. Outros tantos revelaram/revelam se sentir atraídos por outros homens (cis ou trans), ou seja, mesmo após transicionarem, continuam tencionando a cisheteronormatividade.

O que Benjamin (1966), Jeffreys (2002) e diversos outros - mutiladores de gênero - autores, cientistas, médicos, professores e outros personagens presentes nas mais diversas instituições fascistas não previam era que o comportamento sexual e a capacidade de subverter os discursos médicos reguladores fosse ainda permanecer forte, presente e inalterável nas produções das subjetividades de diversos indivíduos transmasculinos (Neves, 2015).

Aqui me aproprio e faço uso proposital do verbo mutilar, como contraponto aos discursos reacionários em relação à transição médica. Diversas pessoas, principalmente alguns profissionais da área da saúde, não acreditam na transição médica e creem que aqueles/aquelas que dela participam, sejam mutiladores/mutiladoras de corpos. Dean Spade, em Mutilating Gender (2000), associa o verbo mutilar, não ao que deveria ser apenas mais um procedimento cirúrgico específico, mas à covardia com que alguns serviços e instituições das mais diversas, mutilam as diferentes expressões de gênero e identidades. Gosto de pensar na ideia de nós, pessoas trans, reapropriarmo-nos do verbo mutilar e darmos a ele outro significado. Não sinto que eu tenha um corpo mutilado. Meu corpo está muito longe disso. Meu corpo é livre e legítimo. Não me senti/sinto mutilado por meus cirurgiões, mas me sinto mutilado pelas autoridades médicas que insistem em nos patologizar e a em exterminar com todas e quaisquer outras 
possibilidades de se viver a vida. Não sou um transexual "verdadeiro", sou um mutilador de gênero (Neves, 2015).

Existem inúmeros indivíduos transgêneros/transmasculinos que são homossexuais, por exemplo. São esses indivíduos que furam os discursos médicos para obterem as mudanças corporais que desejam. Eles dizem exatamente aquilo que os médicos desejam ouvir. E os médicos por sua vez, entendem o que está sendo dito e muitas vezes sabem que aquele discurso não é verdadeiro. Ainda não há detector de mentiras nas clínicas ou nos centros especializados para as pessoas transmasculinas.

Não há diagnóstico ou testes suficientes que caibam os nossos desejos. Fora do ambiente médico-regulador, esses indivíduos podem usar e abusar de diferentes papéis de gênero. Ainda que o "corpo vestido" nos informe um papel específico e uma performance sexual 'heterossexual compatível', esses sujeitos vão ou podem experimentar ao longo de suas existências, diversas outras performances.

É nessa tensão do "me diga a verdade que eu quero ouvir, mesmo eu sabendo que ela é uma mentira", que as pessoas transgêneras acabam se submetendo a manutenção da patologização e do diagnóstico dos seus desejos e ainda, que consequentemente, parte de algumas equipes médicas também não repensa seu próprio discurso. Como garantir um atendimento acolhedor, especializado, seguro e gratuito, se as pessoas forem contra a patologização da transexualidade?

A masculinidade hegemônica que nós (re)conhecemos e confiamos, só existe porque outras versões de masculinidades, consideradas subalternas, também existem. Uma depende da outra. Uma se sustenta por conta da outra. Um outro exemplo dessas outras versões de masculinidade, é a produzida por pessoas transmasculinas, como a dos homens trans ou das pessoas não binárias. Longe de serem imitações das masculinidades produzidas por homens, essas produções nos mostram como a masculinidade é construída como masculinidade. Como essas masculinidades são subalternas, recebem menos créditos e parecem menos legítimas ou inexistentes.

Na maior parte dos estudos acadêmicos sobre masculinidade dos homens, há uma lacuna acerca das discussões sobre outras masculinidades, incluindo nesse rol as transmasculinidades. Na antologia editada por Paul Smith, Meninos: Masculinidades na Cultura Contemporânea, para uma série sobre Estudos Culturais, Smith sugere que a masculinidade deve ser 
sempre pensada no plural, como masculinidades e definidas e recortadas por diferenças e contradições de todos os tipos.

Todavia, ao longo dessa obra, Smith (1996) não consegue fazer a desconstrução da masculinidade dos homens e biológica com a figura poderosa do homem branco. Embora ele reconheça a força de vozes subalternas que produzem outras masculinidades, ele não as legitima, ou seja, ele continua fazendo delas algo menor.

Smith (1996) nos inquieta, uma vez que, conforme ele nos apresenta, a soma da masculinidade com a hombridade é que faz com que ela tenha legitimidade social. Seria preciso que prestássemos mais atenção nessa masculinidade hegemônica para que pudéssemos (re)construí-la ou destruíla. Halberstam (1998) nos aponta que é exatamente porque a masculinidade branca ofuscou e ofusca todas as outras masculinidades, que temos que afastar essa construção dos holofotes e trazer à cena todas as outras masculinidades e suas distintas construções.

Retomando Theodoro, o artista, assim como diversos homens trans, faz reposição hormonal com testosterona (hormônio masculino), que dá características secundárias masculinas ao corpo da pessoa transmasculina. No entanto, a leitura social ${ }^{615}$ de homem cisgênero que a testosterona dá a diversos homens trans, incluindo a do cantor em questão, acaba por apagar as demais categorias identitárias e principalmente, a sexualidade ou a não existência de sexualidade nessas pessoas.

Homens trans que têm leitura social de homens cisgêneros são muito mais que meras simetrias da cisheteronormatividade. Muitos são mutiladores de gênero (Neves, 2015) e na minha cultura, na cultura transmasculina, não se apaga a leitura social e vivências dos anos que vivemos e sofremos todas as

\footnotetext{
${ }^{61}$ Eu e alguns outros autores trans, temos preferido adotar o conceito de leitura social cis em detrimento ao termo passabilidade. 0 último termo pode trazer no imaginário cisgênero de que somos pirataria, pessoas que querem enganar a cisgeneiridade, passando-nos por pessoas que não somos. Entendemos e temos consciência das vantagens sociais e não privilégios (PEÇANHA, 2018), que essa leitura cisgênera nos dá, mas ao mesmo tempo, essa mesma leitura pode e nos invisibiliza. Um homem trans que possua essa leitura social de homem e que já tenha feito a retificação de seus documentos, não consegue mais acessar serviços em ginecologia, exceto, com sorte, em centros de referência transexualizadores (há apenas 05 no país). Onde está o privilégio de se contrair uma simples candidíase e não conseguir atendimento médico e nem muito menos receita médica (exceto no mercado ilegal), para se tratar?
} 
delícias e as mazelas de sermos identificados e socializados como "mulheres héteros".

Até o presente momento histórico em nosso país, não nos foram ofertados outros códigos morais ou filosóficos como o da ética de si.

Diversos homens trans foram, são ou serão espancados, mortos, sofrem abusos sexuais, assédios laborais - quando conseguem empregos- deixam de se locomover, de explorar determinados espaços geográficos, porque o mapeamento de circulação é restritivo e policiado para mulheres e pessoas trans, especialmente as de classes sociais mais baixas e negras.

Concluindo, diversos homens trans engravidam e também sobrem abusos sexuais, abortam, menstruam, são silenciados, diagnosticados como insanos, inapropriados, abjetos. Carentes de todas as políticas públicas básicas e, muitas vezes, também de afeto. Poder ver esse corpo transmasculino dando uma sarrada no ar no corpo de uma travesti, não é e nunca será, dentro de uma cultura travestigênere, machista, e não representa a mesma ideia ou cultura de um homem cisgênero heterossexual, performando o mesmo. 


\section{REFERÊNCIAS}

BUTLER, J. Corpos que pesam: sobre os limites discursivos do "sexo". In: LOURO, Guacira L. o corpo educado: pedagogias da sexualidade. 2. ed. Belo Horizonte: Autêntica, 2001.

CHAUÍ, M. Cultura y Democracia. En publicación: Cuadernos del Pensamiento Crítico Latinoamericano no. 8. Buenos Aires: CLACSO, Consejo Latinoamericano de Ciencias Sociales. Mayo 2008 Disponível em: <http://bibliotecavirtual.clacso.org.ar/ar/libros/secret/cuadernos/ chaui/chaui.pdf>. Acesso em: 15 set.2018.

CONNEL, R. Gênero em termos reais. São Paulo: nVersos, 2016.

GONDRA, J. Para uma vida não-fascista. Belo Horizonte: Autêntica, 2009.

LIMA, M. F. Corpos, Gêneros, Sexualidades: Políticas de Subjetivação. Porto Alegre: Rede Unida, 2014.

NEVES, B. Transmasculinidades e o cuidado em saúde: desafios e impasses por vidas não fascistas. Dissertação de Mestrado. Programa de Pós-Graduação em Clínica Médica. Faculdade de Medicina. Universidade Federal do Rio de Janeiro, 2015.

NLUCON. Kaique Theodoro lança clipe "Dom" e faz todos mexerem a raba. Disponível em: <https://nlucon.com/2018/07/09/kaique-theodoro-lanca-clipe-dom-e-faz-todosmexerem-a-raba/>. Acesso em: 15 set. 2018. 


\title{
BRICOLAGEM PARENTAL: ANÁLISE CARTOGRÁFICA FÍLMICA DE FILIAÇÃO NA CONFIGURAÇÃO FAMILIAR SINGULAR APRESENTADA EM PATRIK1.5
}

\author{
Lorena Lopes de Oliveira \\ Márcio Alessandro Neman do Nascimento
}

A família está em pauta. Anunciada, muitas vezes, como morta, esfacelada e decadente, ainda assim desponta como uma das mais importantes instituições na (trans)contemporaneidade e que produz subjetividades refratadas em práticas sociais cotidianas e organizadoras da vida em sociedade. Enquanto construção sócio-histórico-política e cultural, a família tem sofrido e produzido em seu itinerário cartográfico conflitos sociais, ideológicos, econômicos, entre outras estilísticas de existências. Em concomitância, enquanto um dispositivo normatizador potente, tem apresentado transformações significativas e aceleradas que impactam suas estruturas, constituições, funções e, subsequentemente, suas definições e conceitos.

A família está nas telas do cinema, que, como outras mídias, assumiu e/ou recebeu o papel de reproduzir e legitimar condutas sociais. Como afirma Guacira Louro (2008), o que é apontado nos filmes como o correto, o aceito, o saudável e o normal acaba por ser incorporado pela sociedade como moralmente bom. $O$ grande problema dessa situação está em que tipos e estereótipos estão sendo apresentados e representados nesses filmes. Os estereótipos são, basicamente, representações generalizadas de uma determinada classe ou grupo de pessoas.

Neste trabalho, pensamos o cinema como uma "máquina de guerra", no sentido de afrontar valores e propiciar experimentos estéticos mais próximos da vida. Compreendemos cinema enquanto instância que pode constituir objetos ao mesmo tempo em que incentiva ações políticas, 
que simboliza o real vivido e transfigura as questões relativas à inserção de sujeitos e grupos marginalizados e excluídos frente às demandas da sociedade moderna e capitalista. De acordo com Paulo Menezes (1998), no mundo (trans)contemporâneo, as imagens ocupam um lugar social que não pode ser subestimado e são uma forma de expressão relacionada a como a sociedade se concebe visualmente.

O cinema se apresenta como fenômeno da lógica capitalista numa rede complexa de agenciamentos dados a partir das relações entre público e obra artística. Segundo Cristiane Gutfreind (2005), o cinema pode ser compreendido como uma estrutura plural que engloba produção, consumação, hábitos, criatividade e valores simbólicos e imaginários que dizem respeito a uma sociedade local, sendo capaz de retificar comportamentos, modos de pensar e ser. Em outras palavras, ele pode reproduzir a ordem dominante, seus valores, crenças e ideologias, ditando moda, hábitos e valores culturais de uma elite social, produzindo subjetividades e modos de existência idealizados e modos de (in)felicidades e (in)sucesso.

\section{O declínio do império familiar}

De acordo com Gilles Deleuze (1992, p. 220), desde o final da Segunda Guerra Mundial a sociedade tem enfrentado modificações e crises diante da transfiguração de um modelo disciplinar à sociedade de controle:

Encontramo-nos numa crise generalizada de todos os meios de confinamento, prisão, hospital, fábrica, escola, família. A família é um "interior", em crise como qualquer outro interior, escolar, profissional, etc. Os ministros competentes não param de anunciar reformas supostamente necessárias. Reformar a escola, reformar a indústria, o hospital, o exército, a prisão; mas todos sabem que estas instituições estão condenadas num prazo mais ou menos longo. Trata-se apenas de gerir sua agonia e ocupar as pessoas, até a instalação de novas forças que se anunciam. São as sociedades de controle que estão substituindo as sociedades disciplinares.

As estratégias de controle são expostas na mídia e anunciadas nos dispositivos legais, que expõe publicamente histórias cabulosas (porém, factuais) de vidas privadas, produzindo desejos e práticas normatizadoras 
na sociedade, adentrando ao bojo familiar e criando uma atmosfera de autoacusação e denúncias.

Dentre as exposições midiáticas que abalaram a opinião pública se encontram casos como os da família de Suzane von Richthofen, o assassinato de Isabella Nardoni, o assassinato de Eloá62 e o assassinato do menino Joaquim, entre outros crimes que envolvem parentalidades, consanguinidades e vínculos afetivos, além da clássica obra de Michel Foucault (1977) Eu, Pierre Rivière, que degolei minha mãe, minha irmã e meu irmão, que pelo título nos salienta o modo como a justiça criminal adentra ao seio familiar. Também apontamos os programas de auditório onde a família é estraçalhada por apresentadores, participantes e plateia, que promulgam discursos sobre a falência e fragilidades do seio familiar ao mesmo tempo em que recusam anunciar a decadência do modelo familiar idealizado, mesmo na atualidade.

Ainda, em ritmo de denúncias, famílias são acusadas e intimadas por órgãos ligados ao judiciário, tais como o Conselho Tutelar, para verificar abandono, negligência e maus-tratos ocasionados, em uma análise macropolítica, por uma organização globalizada de mundo neoliberal, que gira em torno do capital e do trabalho e produz vínculos afetivos fragilizados e efêmeros. Quem nunca ouviu alguém próximo desabafar dizendo que não passa tempo com os filhos e/ou que transferiu a educação e os cuidados às avós, baby sitters ou escolas porque precisava trabalhar para pagar as contas do colégio, do smartphone, do lazer de fim de ano, do consumo de novas tecnologias da moda?

Isso possibilitou o surgimento de políticas públicas voltadas preferencialmente às famílias, como os programas de transferência de renda, que objetivam combater a pobreza e erradicar a miséria. Entre algumas políticas, podemos citar o CRAS/PAIF (Centro de Referência de Assistência Social/Programa de Atenção Integral à Família) e o NASF/ESF (Núcleo de Apoio à Saúde da Família/Estratégia Saúde da Família). Temos, por exemplo, ações que buscam resgatar a cidadania das famílias em situação de vulnerabilidade demarcada pelos indicadores sociais: Programa Bolsa

\footnotetext{
${ }^{62}$ Casos de homicídios anunciados de modo estigmatizado pela mídia, pelo sistema jurídico e pelo senso comum e apontados como consequência de modelos de famílias "desajustadas", "desestruturadas" e "pouco protetivas". Isso aponta um fenômeno de publicização dos problemas privados de algumas famílias pela opinião pública.
} 
Família, Programa Erradicação do Trabalho Infantil, Programa Poupança Jovem, entre outros.

Todavia, historicizar a família contemporânea é importante para entender os processos que a constituem e a fragilizam, uma vez que essa instituição nem sempre se (des)configurou como se apresenta atualmente. Philippe Áries (1981) indica que os laços afetivos que constituem o grupo social denominado "família" se modificaram ao longo da história da humanidade, sendo principalmente permeada pela relação de cuidado com as crianças. Na família medieval o contexto familiar era um lugar moral e social e menos sentimental, sendo que a relação com os progenitores era dada por visitas esporádicas que mantinham o vínculo consanguíneo de respeito e admiração:

[...] a criança desde muito cedo escapava à sua própria família, mesmo que voltasse a ela mais tarde, depois de adulta, o que nem sempre acontecia. [...] A família era uma realidade moral e social, mais do que sentimental. No caso de famílias muito pobres, elas não correspondiam a nada além da instalação material do casal no seio de um meio mais amplo, a aldeia, a fazenda, o pátio ou a "casa" dos amos e dos senhores, onde esses pobres passavam mais tempo do que em sua própria casa. Nos meios mais ricos, a família se confundia com a prosperidade do patrimônio, a honra do nome (ARIÈS, 1981, p. 231).

Entretanto, no século XV teve início uma nova e lenta configuração a respeito dos sentimentos e laços familiares, trazida pela emergência da frequência dos filhos no âmbito escolar para efetivar a passagem da infância para o mundo adulto e pela necessidade de rigor moral, que visava preservar uma inocência primitiva outrora não existente e/ou esquecida (ARIÈS, 1981). No século XVIII, a família começou a enaltecer uma vida cada vez mais particular e privada, constituindo o que denominamos "arquitetura familiar".

A característica dessa nova "velha" família é a tentativa de igualdade entre seus filhos. No século XVIII, a desigualdade entre os filhos de uma mesma família passou a ser considerada uma injustiça intolerável. No entanto, essa igualdade se limitava a assumir a legitimidade dos filhos e garantir alguns cuidados básicos, uma vez que processos de opressões transpassados por machismo, sexismo, capacitismo e outros impossibilitavam de fato a igualdade. De qualquer forma, a criança burguesa se tornou um elemento 
indispensável da vida quotidiana, preocupavam-se com sua educação, carreira e futuro (e casamento, no caso das meninas).

Sobre a família moderna, Claudia Fonseca (1998) argumenta que essa instituição se expandiu do modelo de casal heteronormatizado para outras relações e estruturas de parentesco, o que permitiu o surgimento de novas formas de filiação para além do tradicional laço biológico e ampliou as pesquisas e discussões em relação às novas concepções e tecnologias de família.

De acordo com José Roberto Reis (1984), a família manifesta fortes resistências à mudança, mas, apesar disso, passa por processos de transformações assim como toda instituição social. Observa-se, a partir do início do século XX, consideráveis transformações no cotidiano doméstico: a possibilidade de escolha do parceiro pelos cônjuges, a redução no número de membros, a valorização da afetividade entre os pais e a prole, a inserção da mulher no mercado de trabalho e na universidade, a inserção dos filhos no mercado de trabalho, o grande índice de divórcios, os casais homoafetivos, etc. Todavia, bem como afirma Luiz Mello (2005, p. 202):

Seguramente, não é exagerado dizer que setores da sociedade brasileira, geralmente influenciados por ideologias familiaristas e naturalistas de origem religiosa, têm se revelado bastante resistentes aos discursos e às vivências de lésbicas e gays que procuram afirmar o direito à liberdade de orientação sexual e a legitimidade dos agrupamentos familiares que fogem ao padrão nuclear moderno, formado por um "homem instrumental" unido a uma "mulher expressiva", juntos socializando crianças felizes, nos termos do modelo parsoniano.

A história da adoção tem um percurso extenso no Brasil, desde a época da colonização. A princípio esteve relacionada com caridade, em que os mais ricos prestavam assistência aos mais pobres. Era comum haver no interior da casa das pessoas abastadas filhos de terceiros, chamados "filhos de criação". A situação dessas pessoas no interior da família não era formalizada, servindo sua permanência como oportunidade de mãode-obra gratuita (PAIVA, 2004) e, ao mesmo tempo, como auxílio aos mais necessitados, conforme pregava a Igreja.

Tal herança cultural contribuiu significativamente para que, até os dias de hoje, essa forma de filiação seja impregnada por mitos e preconceitos. 
Discriminação ainda maior se pesou em adoções feitas por casais homoafetivos, como expõe Anna Paula Uziel (2007, p. 14).

Entre os novos arranjos familiares, os compostos por gays são os mais controversos, embora a educação de crianças por pais homossexuais não seja novidade. Este fenômeno adquiriu visibilidade com o crescimento e força que o movimento vem ganhando nos últimos anos. A estabilidade do relacionamento entre pessoas do mesmo sexo e seu desejo de ter filhos desperta a curiosidade de muitos, que desconfiam de uma impossibilidade, inadequação, impropriedade.

Fonseca (2008) desenvolve essa discussão ao destacar a influência da ciência nesse debate, de um lado reforçando a importância do fator biológico na definição de família por meio de testes de DNA e, por outro, colocando em xeque as ideias preconcebidas sobre o que vem a ser "família natural" ao difundir a utilização de inseminações, barrigas de aluguel, etc. Enfim, abandonar essa noção biológica se torna fundamental para que a adoção e as relações afetivas sejam construídas sem preconceitos e sofrimento. Devido a essa concepção, a adoção e a história de vida das crianças são, em muitos casos, silenciadas.

\section{Filme Patrik 1.5 observado a partir de um posicionamento esquizoanalítico}

Antes de continuarmos, talvez seja necessário realizar uma breve contextualização acerca da Esquizoanálise, termo cunhado por Gilles Deleuze e Félix Guattari com a publicação do livro O Anti-Édipo, em 1972, designando uma série de críticas à teoria psicanalítica clássica, propondo um novo modo de analisar as produções de subjetividades. Segundo Márcio Nascimento (2015, p. 148), a Esquizoanálise é um posicionamento teórico-metodológico que,

[...] propõe análises e intervenções no campo social, a partir de atravessamentos que desinstitucionalizam os campos conceituais e técnico-práticos como áreas distintas, ou seja, aborda as parcialidades e a inseparabilidade entre as produções desejantes e o contexto sóciohistórico, político e cultural para pensar as conexões entre processos coletivos e produção de saberes localizados. 
Configurando-se como uma espécie de "caixa de ferramentas" que pode inspirar uma análise híbrida e localizada das macro e micropolíticas dos acontecimentos sócio-histórico-políticos e culturais, a Esquizoanálise se atenta aos agenciamentos de práticas que escapam da ordem vigente e de interpretações superficiais e/ou de constructos hipotéticos universais, essencialistas e binários, rompendo com os saberes instituídos em troca de um saber rizomático. A potência da Esquizoanálise surge como resistência aos modelos individualizantes das produções desejantes e de subjetividades, compondo-se como estratégia para pensar estilísticas de existências e cartografar paisagens psicossociais e produções de subjetividades. Dessa maneira, a Esquizoanálise não se configura como um método rígido, podendo ser entendido como um anti-método ou um posicionamento teórico-metodológico da experiência, que investe na ideia de que há infinitas formas de se compor a vida.

Patrik 1.5 (Patrik, Age 1.5) é um filme sueco de 2008 dirigido por Ella Lemhagen e baseado na peça teatral de mesmo nome, escrita por Michael Druker. O longa retrata a história de um casal de homens cis gays, Göran e Sven, que sonham em adotar um bebê e expandir a família. Para além de todos os preconceitos e barreiras vivenciados pelo casal na busca de adotar o tão desejado filho, uma obra do acaso modifica os planos previamente definidos.

Após um longo processo judiciário, o casal consegue a guarda de Patrik, de apenas 1 ano e 5 meses. Todavia, o que eles não esperavam era a chegada de um adolescente de 15 anos, com posicionamentos homofóbicos e com histórico de infrações legais. Um simples erro de pontuação na elaboração de um documento (re)significa na vida do casal e de Patrik uma série de incertezas e (des)encontros, uma multiplicidade de agenciamentos e processos potencializadores. É a partir dessa narrativa que constituiremos uma análise, abordando temas sociais como adoção tardia, marginalidade e famílias homoparentais.

\section{Cartografia fílmica: "um recorte no corte ou um rasgo na ferida aberta"}

As relações afetivo-sexuais dissidentes da matriz heterossexual sempre existiram, mas ainda hoje são marcadas por processos de estigmatização e vistas como marginais, anormais e imorais. Como afirma Luiz Mello (2005), 
ideologias conservadoras produziram/produzem discursos de que essas relações são pecado, doença e crime, o que contribuiu para que pessoas que vivenciam essas relações sofram processos concomitantes de rejeição, ódio, intolerância, preconceito e discriminação. Essas estilísticas da existência são "classificadas" a partir de uma matriz heteronormativa, que, segundo Nascimento (2015, p. 95), se "constituem como um conjunto de instituições (linguísticas, médicas, psicológicas, científicas, domésticas) que produzem incessantemente corpos-mulheres e corpos-homens".

No longa apresentado, esse discurso de ódio cristalizado no corpo social é facilmente observado, seja pelas barreiras burocráticas impostas pelo sistema judiciário no processo de adoção, pelos julgamentos e condenação dos vizinhos ou pela própria recusa de Patrik em ser adotado pelo casal homossexual.

Quase desacreditando da concretização do sonho de adotar uma criança, Sven e Göran são surpreendidos pela notícia de um menino disponível. Em uma manhã fria, bate à porta um adolescente de 15 anos. Göran, sem entender a situação, o convida a entrar. Com o desenvolver da conversa, ele percebe que o garoto sentado na cozinha é seu filho Patrik, que deveria ter um ano e meio de idade. Um ponto no local errado (1.5) originou a confusão. E agora?

Patrik se apresenta como um jovem homofóbico, identificado como "problemático" e solitário. Atravessado por pressupostos preconceituosos e estigmatizantes, Patrik se recusa a compor uma família com dois pais, mesmo estando em uma situação de vulnerabilidade, exclusão e às margens do sistema. A resistência do adolescente é comum no meio social e decorre da falsa ideia de que relações homoafetivas são promíscuas e incompatíveis com um ambiente saudável para o bom desenvolvimento de uma criança e/ ou adolescente, suposições que servem, entre outras coisas, para mascarar o preconceito individual e social.

Esses são discursos vinculados pelos "defensores da moral e dos bons costumes", partidários da tradição heteronormativa, que sustentam argumentos de que a falta de referências comportamentais heterossexuais pode acarretar sequelas de ordem psicológica e dificuldades na identificação sexual da criança. Ao contrário dessas alegações sem embasamento científico contundente, diversos estudos desmistificam esses e outros preconceitos sobre a adoção por casais de mesmo sexo biológico ou identidade de gênero 
(BARRETT, TASKER, 2001; BEAUMATIN, RICAUD-DROISY, ESPIAU, 2003; DORTIER, 2002; FARIAS, 2010; FINE, LATERRASSE, ZAOUCHE-GAUDRON, 1998; FONSECA, 2008; FUTINO, MARTINS, 2006; LANGOUËT, 1998; MEDEIROS, 2006; MELLO, 2005a; PERELSON, 2006; SILVA, SOLIS-PONTON, 2004; ZAMBRANO, 2006).

Elizabeth Zambrano (2008) analisa que o estranhamento da consolidação de uma família que se esquiva do relacionamento heterossexual se associa com aquilo que não pode ser representado na cultura. Em conformidade, Judith Butler (2015) argumenta que estamos diante de uma norma compulsória implícita nas relações sociais, que impõe uma coerência total entre sexo, gênero e desejos que obrigatoriamente devem ser heterossexuais.

No início do filme, a câmera passeia em meio a uma confraternização da vizinhança. Todas as famílias foram convidadas, crianças correm felizes em meio aos casais heterossexuais, que conversam sobre seus trabalhos, a segurança do quarteirão e suas vidas tranquilas e rotineiras em um subúrbio pacato constituído majoritariamente por famílias de classe média brancas que compartilham hábitos alimentares, vestimentas, lazer, crenças e valores e congregam a mesma ideologia de vida baseada em um ideal de humano sustentado pelo consumo, pelo padrão de família mononuclear e por concepções a respeito de beleza, de gênero e de regras para alcançar o sucesso, a estabilidade financeira e a tão desejada felicidade.

Na cena, podemos observar a padronização na arquitetura das casas e os mesmos modelos de carros, hábitos e comportamentos alicerçados no American Way of Life (Estilo de Vida Americano), difundido pelo mundo por meio das produções cinematográficas hollywoodianas a partir da década de 1930 e que simboliza uma forma de existir e compor a vida pautada em uma relação íntima com o consumo e o descarte.

Göran e Sven, recém-chegados, deparam-se com uma vizinhança aparentemente divertida e acolhedora, mas que se demonstra menos receptiva ao descobrir o relacionamento amoroso dos dois homens e o desejo de adotar uma criança. Göran e Sven passam a conviver com sorrisos amarelos e olhares interrogativos, além de reações constrangedoras por parte da vizinhança e demais pessoas.

De algum modo, a família composta por dois homens representa, naquele ambiente, uma "ameaça” à ordem hegemônica heterossexual, na qual a felicidade está supostamente centrada. Ao fugir à regra, Göran e Sven são excluídos das relações sociais da comunidade, uma vez que rompem 
com as justificativas em que se pautam os posicionamentos contrários às constituições familiares singulares (homoparentais, monoparentais, interraciais, entre outras), demonstrando que as famílias homoparentais podem contribuir igualmente para os fins da instituição família. O debate sobre homoparentalidade coloca em "xeque" os pressupostos e ideias de uma instituição que, em algumas culturas e sociedades, é vista como imutável e se submete a várias convenções religiosas e morais. Sociedades ortodoxas são mais presas a estereótipos que dificultam a aceitação dos novos modelos familiares.

Butler (2008) utiliza o termo abjeção para discutir a repulsa e a negação ao diferente. A abjeção se fundamento no repúdio e na patologização de um significante/sujeito/classe, para que este seja empurrado a ocupar uma posição marginal, na condição de inominável, inaceitável, intolerável, indesejável, abominável e de excremento, sendo relegado da condição de humano e sujeito de direitos.

Ao falarmos sobre a instituição família, podemos recorrer aos estudos de Foucault sobre a ordem dos discursos, que impõem padrões e parâmetros que se objetificam nos corpos, produzindo corporificações assujeitadas às regras normativas, às instituições disciplinares e à matriz heterossexual, naturalizada e concebida como universal. Esse processo culmina naquilo que Foucault (1987, p. 118) conceituou como corpo dócil, “[...] que pode ser submetido, que pode ser utilizado, que pode ser transformado e aperfeiçoado".

Essa ordem normativa, segundo Maria Isabel Bujes (2003), institui na modernidade as relações de saber-poder por meio de operações que implicam o uso da coerção contra as crianças, que se tornam objetos da disciplina e do controle por meio da relação adultocêntrica. De acordo com Foucault (2010), a disciplina fabrica corpos submissos e exercitados, permitindo a eficácia do controle sobre os gestos, a atitude e a economia dos movimentos do corpo.

Sendo assim, a norma representa um crivo de conduta que serve para diferenciar os normais - que correspondem ao padrão estipulado - dos anormais. Esse processo de normatização social estabelece que tudo e todos que desviam da norma, que se encontram às margens do padrão, serão classificados como sintomáticos, representando uma clara ameaça à normalidade vigente, devendo ser combatida e exterminada se possível. 
Nas cenas que se seguem, Göran e Sven sofrem com os olhares julgadores, com a exclusão, com a recusa em serem reconhecidos como família, com as barreiras impostas no sistema de adoção, com as críticas e com a condenação por fugirem da normatização da vida. Sempre existe um dedo em riste, uma fala preconceituosa e julgamentos.

Essas condutas discriminatórias são empregadas para estruturar os mais diferentes segmentos da paisagem social, inclusive para determinar o que é uma família normal, entendendo-a como aquela capaz de gerar filhos e concebida segundo padrões de uma moral social, religiosa e biológica. Isso implica dizer que as demais configurações familiares que desviam dessa normativa são classificadas como "anormais" e/ou desestruturadas.

Todavia, a homoparentalidade e outras constituições familiares singulares, apesar de escaparem da norma vigente, buscam por pertencimento e aceitação social na tentativa de transpor uma série de violências e restrições. Segundo Brunella Rodriguez et al (2015), o desejo dos homossexuais de constituir uma família pode estar relacionado a uma procura por pertencimento, de fazer parte de uma instituição legitimada e valorizada socialmente. Nessa procura, os casais homoafetivos tendem a seguir as regras da sociedade "dominante", operando segundo os pressupostos heteronormativos baseados em relações verticais.

Podemos relacionar isso à decisão de Göran e Sven de morar naquele bairro específico, "considerado bairro de família" e à constante revitalização do jardim feita por Göran, que funciona como uma metáfora, ao passo que representa a construção da família perfeita que ele deseja. Também não podemos deixar de falar do perfil de criança desejado pelo casal, que não foge do padrão, um bebê saudável e preferencialmente de pele branca.

De acordo com Leila Paiva (2004), ainda hoje há dificuldade em reconhecer que os laços familiares são criações socioculturais e que podem ou não ocorrer junto aos laços biológicos. Nesse sentindo, a adoção tem representado, há muito tempo, a possibilidade de formar uma família assentada não na biologia, mas na cultura, no recorte simbólico sobre o corpo.

\section{Adoção: o filho do coração?}

A adoção realizada por pares homoafetivos é ainda um tema bastante polêmico no Brasil por se opor a dogmas e pressupostos conservadores 
defendidos por uma considerável parcela da população. Essa discussão ganhou mais destaque em 2011, após a decisão do Supremo Tribunal Federal de reconhecer a união estável de pessoas do mesmo sexo biológico.

Em Patrik1.5, apesar da história se passar em um país europeu, a realidade não se apresentava tão diferente da brasileira durante o período histórico em que o filme foi produzido, como podemos perceber na cena em que Göran e Sven são informados que nenhum país está disposto a conceder a guarda de uma criança para um casal homossexual. E quando o fazem, concedem a guarda de um adolescente que nenhuma família tinha o interesse de adotar.

No Brasil, desde a Constituição de 1988, a adoção é entendida como uma medida protetiva à criança e ao adolescente. O Estatuto da Criança e do Adolescente (ECA), publicado em 1990, reconhece a convivência familiar e comunitária como direito fundamental de toda criança e adolescente, estabelecendo a possibilidade de colocação em família substituta mediante guarda, tutela ou adoção, nos casos de abandono ou situação de risco junto à família de origem. Todavia, ainda há muito o que se efetivar na execução dessas garantias e direitos.

Segundo dados do Cadastro Nacional de Adoção (CNA) publicados em 2020, o Brasil possui 34,8 mil crianças e adolescentes em casas de acolhimento e instituições públicas. Mais de $60 \%$ são adolescentes e a divisão entre os gêneros é quase idêntica. Ainda segundo o CNA, a fila de adoção é demorada porque das crianças e adolescentes disponíveis que não estão vinculados $83 \%$ têm acima de 10 anos e apenas $2,7 \%$ dos pretendentes aceitam adotar crianças e adolescente acima dessa faixa etária.

Segundo Fernando Silva Teixeira Filho (2010), a maior parte dos casais que recorrem à adoção já possui uma criança idealizada e muitas nem sequer cogitam a ideia de poder exercitar o convívio com as diferenças. Desse modo, as crianças que não correspondem ao perfil de preferência dos adotantes (meninos, negros, maiores de três anos) tendem a permanecer nos abrigos sem perspectivas reais de saída até a maioridade.

No filme, Patrik é um adolescente de 15 anos com um histórico de infrações e comportamentos descritos como problemáticos. Órfão de mãe, o rapaz não chegou a conhecer o pai e desde pequeno se encontra no sistema de adoção, o que fez com que crescesse sem família, afeto, carinho e cuidado, fugindo de abrigos e sendo obrigado a voltar para eles, vivenciando 
o abandono e suas implicações. Rotulado como "garoto problema" e estigmatizado, Patrik devolve à sociedade o que desta recebeu: desprezo e agressividade.

O adolescente autor da prática de qualquer "infração penal" é visto como um delinquente, um marginal, um potencial criminoso quando adulto. De acordo com Rodrigo Gusso (2011), a adolescência, da forma como hoje é tratada, converteu-se em uma imagem social violenta e muitas vezes criminosa. Essa criminalização da adolescência e juventude é fundamentada nos estereótipos sociais e processos de estigmatização sustentados por uma cultura segregatória e perversa. Refletindo a partir da realidade brasileira, o adolescente considerado perigoso e/ou criminoso é em sua esmagadora maioria um menino, negro, pobre, morador de regiões periféricas. Nessa rotulação social, a mídia, a família, os amigos, a escola e até políticas públicas de governo são responsáveis por produzir e sustentar tais estereótipos.

Esse cenário se torna ainda mais preocupante quando voltamos nosso olhar aos adolescentes presentes no sistema de adoção e aos autores de atos infracionais que se encontram "depositados" em casas de apoio pelo Brasil. Segundo Gusso (2011), esses adolescentes carregam uma imagem social negativa, problemática e propositadamente criminosa e são excluídos pelo sistema social, que lhes atribui uma identidade delinquente, mesmo estes estando amparados por legislações como ECA e a própria Constituição Federal.

No filme, Patrik possui um passado trágico, descoberto com o desenrolar da trama. Sentado em um banco, após uma corrida com Göran, Patrik relata que segundo o que lhe contaram, sua mãe morreu quando ele era um bebê, tendo sido cogitada a hipótese de overdose por droga. Patrik foi encontrado junto ao corpo da mãe após $24 \mathrm{~h}$ da morte. Em outro momento, em uma conversa descontraída com Göran, Patrik fala que a mãe era uma garota de programa e que não chegou a conhecer o pai, mas desconfia que deve ser um dos clientes de sua mãe. Ao ser questionado por Sven se teria algum parente que pudesse ficar com ele, Patrik fala que tem uma tia que ameaçou soltar os cachorros nele se algum dia aparecesse em sua casa.

Patrik jamais foi cuidado e tratado com carinho ou respeito. À margem da sociedade, privado de uma infância lúdica e descontraída, cresceu sem saber o que era ser amado. Teve que aprender cedo a se cuidar e se defender sozinho e como defesa se fechou para novas relações, tornando-se uma 
pessoa desconfiada e sempre alerta para qualquer eventualidade. Em uma cena, próxima ao final do filme, ao se cortar em um vaso quebrado, Patrik recebe os cuidados de Göran, talvez os primeiros cuidados autênticos em sua vida. O rapaz então se sente protegido e cuidado. Em busca de constituir uma família, Göran e Sven se deparam com Patrik, um jovem que havia perdido as esperanças de ser parte de uma.

Nesse processo, o jardim floresce, na medida em que a relação entre pai e filho se consolida, exibindo todo seu esplendor na primavera. Tratase de uma metáfora que representa os percalços da construção de uma família nada tradicional em um cenário pouco propício. A relação entre aquele homem gay e aquele adolescente "problemático" é como um jardim, que precisa de tempo para florescer e demanda cuidados diários, como ser regado, adubado e tratado. Sven, após resolver seus problemas e dúvidas em relação a compor novamente uma família, decide dar uma chance a si mesmo e à relação com Göran e Patrik.

\section{Considerações... longe de serem finais}

Neste texto, nos preocupamos em descontruir pensamentos fundamentados em normas, leis, tradições e crenças que ditam o existir, que regulam e buscam enquadrar existências singulares em modelos universais, regras arbitrárias que somente visam classificar e agir de modo intervencionista na procura incessante de domesticar e disciplinar as condutas sociais, fundadas em paradigmas binários, como: certo e errado, normal e anormal, bem e mal, feminino e masculino, que só servem para normatizar e reprimir as potencialidades da vida.

Isto posto, durante todo o percurso procuramos assumir um posicionamento ético-político e problematizador que não se prende a um ideal de humano e naturalizações de práticas sociais. No Brasil, as dificuldades impostas pela falta de recursos e investimentos tornam esse fazer ainda mais árduo. Todavia, aceitamos esse desafio e, ao final deste trabalho, percebemos a necessidade cada vez mais real de que estudos sobre famílias homoparentais sejam realizados para compor um "arsenal" acadêmico que consiga se opor fortemente às justificativas que almejam destituir essas famílias de direitos, reconhecimento e dignidade.

Assim sendo, o estudo do filme Patrik 1.5 representa uma estratégia de análise das macros e micropolíticas que compõem as experiências de 
famílias que escapam do modelo tradicional. O cinema é uma engrenagem do maquinário social e uma ótica pela qual podemos nos perceber e nos expressar. Nesse sentido, defendemos que o sujeito, longe de ser definido por uma essência ou um pré-determinismo divino, constitui-se no e pelo discurso, de modo ativo e dinâmico, construindo no "entre" sua realidade e a si próprio, mediado pela relação com o outro e atravessado por ela, num processo sócio-histórico-político e cultural rizomático.

Como afirma Roberta Romagnoli (2009), somos formados a partir de uma tradição moderna, acostumada a fragmentar, a racionalizar e a perseguir a verdade. No entanto, partindo do pressuposto que a realidade não é dada, mas sim construída pelo sujeito, encontramos na cartografia uma possibilidade de quebrar com essa estrutura arcaica de pensar a existência. A cartografia rompe com a dicotomia sujeito-objeto, postulando que a subjetividade é constituída nos "entre", por múltiplas linhas e planos de forças que atuam simultaneamente.

Por fim, só nos resta indagar: o que faz uma família ser família? Longe de tentar fornecer uma resposta pronta e definitiva, propomos a seguinte reflexão: a família é plural, seu elemento é o afeto e sua função, a proteção. Mais do que nunca tem se discutido sobre representatividade nos mais diferentes meios públicos, no cinema não é diferente. Cecilia Wandscheer (2017) afirma que o cinema deve trabalhar com representatividade e exprimir a diversidade e a pluralidade humanas. Nessa perspectiva, Patrik 1.5 permite desenvolver, por meio de seu enredo, discussões acerca de um assunto ainda tão polêmico e de difícil debate em uma sociedade conservadora e moralista como a brasileira. Com isso, o filme direciona um feixe de luz, tirando da invisibilidade essas famílias singulares.

Tratar de temas relacionados a famílias homoparentais é um esforço na busca de contribuir para a diminuição da ignorância e de processos de estigmatização, pois o conhecimento, a experiência e o afeto são nossos principais aliados nessa luta. 


\section{REFERÊNCIAS}

ARIÈS, P. História social da infância e da família. Trad. D. Flaksman. Rio de Janeiro: LCT, 1981.

BARRETT, H., TASKER, F. Growing up with a gay parent: views of 101 gay fathers on their sons' and daughters' experiences. Educational and Child Psychology, 18(1), 62-77, 2001.

BEAUMATIN, A., RICAUD-DROISY, H., \& ESPIAU, G. Approche psychologique de l'exercice de la parentalité chez les couples homosexuels. Pratiques Psychologiques, 2, 45-54, 2003.

BRASIL. Constituição da República Federativa do Brasil. Brasília: Senado. 1988.

BUTLER, J. Cuerpos que importan: sobre los límites materiales y discusivos del "sexo". 2. ed. Buenos Aires: Paidós, 2008.

BUTLER, J. Problemas de Gênero: Feminismo e subversão de identidade. Trad. de Renato Aguiar. 8. ed. Rio de Janeiro: Civilização Brasileira, 2015.

BUJES, M. I. E. Infância e maquinarias. Rio de Janeiro: DP\&A, 2003.

DELEUZE, G; GUATTARI, F. O Anti-Édipo. Rio de Janeiro: Imago, 1976.

DELEUZE, G. Conversações. Trad. de Peter Pál Pelbart. São Paulo. Editora 34, 1992. 232 p. (Coleção TRANS). $7^{\text {a }}$ Reimpressão - 2008.

DORTIER, J. F. Families: Permanences et metamorphoses. Sciences Humaines Édition. Paris: 2002.

FARIAS, M. O. Mitos atribuídos às pessoas homossexuais e o preconceito em relação à conjugalidade homossexual e a homoparentalidade. Revista de Psicologia da UNESP, 9(1), 99-109, 2010.

FINE, A.; LATERRASSE, C.; ZAOUCHE-GAUDRON, C. À chacun sa famille. Toulouse: Éditions Universitaires du Sud. 1998.

FONSECA, C. A modernidade diante de suas próprias ficções: o caso de adoção internacional. In: DORA, Denise et al (Orgs.). Direitos Humanos, Ética e Direitos reprodutivos. Porto Alegre: RML Gráfica, 1998.

FONSECA, C. Homoparentalidade: novas luzes sobre o parentesco. Revista Estudos Feministas, Florianópolis, v. 3, n. 16, p. 769-783, set./dez. 2008.

FOUCAULT, M. Eu, Pierre Rivière, que degolei minha mãe, minha irmã e meu irmão. Rio de Janeiro: Graal, 1977.

FOUCAULT, M. Vigiar e punir. Petrópolis: Vozes, 1987.

FOUCAULT, M. Microfísica do poder. Rio de Janeiro: Edições Graal, 2010.

FUTINO, R. S., \& MARTINS, S. Adoção por homossexuais: Uma nova configuração familiar sob os olhares da Psicologia e do Direito. Aletheia, 24, 149-159, 2006. 
GUSSO, R. B. O processo de estigmatização do adolescente infrator através das representações sociais elaboradas por agentes policiais. Revista Jus Navigandi, ISSN 1518-4862, Teresina, ano 16, n. 2924, 4 jul. 2011. Disponível em: https://jus.com.br/artigos/19464. Acesso em: 29 nov. 2020.

GUTFREIND, C. F. O cinema e sua integração na rede midiática. Logos, v. 12, n. 1, p. 153-165, 2005.

LANGOUËT, G. Les nouvelles familles en France: Observatoire de l'Enfance en France. Paris: Hachette. 1998.

LOURO, G. L. Sexualidade e Cinema. 2008. Disponível em: <http://seer.ufrgs.br/ educacaoerealidade/article/view/6688> Acesso em: 20 ago. 2019.

MEDEIROS, C. P. Uma família de mulheres: Ensaio etnográfico sobre homoparentalidade na periferia de São Paulo. Revista Estudos Feministas, 14(2), 535-547. 2006.

MENEZES, P. Heranças de 68, cinema e sexualidade. Revista de Sociologia da Universidade de São Paulo, São Paulo, v. 10, n. 2, 1998.

MELLO, L. Novas famílias. Rio de Janeiro: Garamond, 2005.

MELLO, L. Outras famílias: A construção social da conjugalidade homossexual no Brasil. Cadernos pagu (24), janeiro-junho de 2005, pp.197-225.

PATRICK 1.5. Direção: Ella Lemhagen. Produção: Tomas Michaelsson. Roteiro: Ella Lemhagen. Intérpretes: Gustaf Skarsgård; Torkel Petersson; Tom Ljungman; Annika Hallin e outros. Suécia: Sonet Film, Regent Releasing here! Films, 2008 (103 min.), son., color.

NASCIMENTO, M. A. N. Corpos (Con)sentidos: cartografando processos de subjetivação de produto (re) s de corporalidades singulares. Tese de doutorado- Faculdade de ciências e Letras de Assis- Universidade Estadual Paulista. Assis-SP, 2015.

PAIVA, L. D. de. Adoção: significados e possibilidades. São Paulo: Casa do Psicólogo, 2004.

Painel detalha estatísticas da adoção e do acolhimento no Brasil. Revista Consultor Jurídico, abril de 2020. Disponível em < https://www.conjur.com.br/2020-abr-01/painel-detalhaestatisticas-adocao-acolhimento-brasil>. Acesso em: 28 de novembro de 2020.

PERELSON, S. A parentalidade homossexual: Uma exposição do debate psicanalítico no cenário francês atual. Revista Estudos Feministas, 14(3), 709-730, 2006.

REIS, J. R. T. Família, emoção e ideologia. In: LANE, Silvia T. Maurer; CODO, Wanderley. (Orgs.). Psicologia Social: o Homem em Movimento. São Paulo: Brasiliense, 1984.

RODRIGUEZ, B. C; MERLI, L. F; GOMES, I. C. Um estudo sobre a representação parental de casais homoafetivos masculinos. Temas em Psicologia, v. 23, n. 3, p. 751-762, 2015.

ROMAGNOLI, R. C. A cartografia e a relação pesquisa e vida. Revista Psicologia \& Sociedade, v. 21, n. $2,2009$.

SILVA, M. C. P., SOLIS-PONTON, L. Ser pai, ser mãe - Parentalidade: um desafio para o terceiro milênio. São Paulo: Casa do Psicólogo, 2004. 
TEIXEIRA FILHO, F. S. Os segredos da adoção e o imperativo da matriz bioparental. Revista Estudos Feministas, 2010, 18(1), 241-261.

UZIEL, A. P. Homossexualidade e adoção. Rio de Janeiro: Garamond, 2007.

WANDSCHEER, C. A importância da representatividade no cinema. Cinematologia, 2017. Disponível em: http://cinematologia.com.br/cine/representatividade-minorias-no-cinema/. Acesso em: 15 mar. 2018.

ZAMBRANO, E. Parentalidades "impensáveis": Pais/mães homossexuais, travestis e transexuais. Horizontes Antropológicos, 12(26), 123-147. 2006.

ZAMBRANO, E. "Nós também somos família": Estudo sobre a parentalidades homossexual, travesti e transexual. Tese (Doutorado em Antropologia), Universidade Federal do Rio Grande do Sul, 2008. Disponível em: <http://www.lumw.ufrgs.br/handle/10183/17649. Acesso em:

20 jun. 2018. 
PARTE IV

MANIFESTOS POR

OUTROS FUTUROS

possíveIs 


\section{MANIFESTA LÉSBICO-FEMINISTA}

Turma 2020 do curso Teorias Feministas e Lesbianidades

Essa manifesta foi construída por discentes e equipe de coordenação do curso Teorias Feministas e Lesbianidades. $O$ curso contou com a presença majoritária de lésbicas, tanto como cursistas, quanto como coordenação. Foi realizado no semestre suplementar da Universidade Federal da Bahia (UFBA), durante o contexto de isolamento social devido à COVID-19, tendo como desafio uma produção integralmente virtual. Também contamos com a colaboração de Ana Carla Lemos na organização final do documento. A construção foi coletiva a partir de uma atividade proposta de construir um manifesto lésbico e foi produzida entre 26 de outubro e 06 de dezembro.

Nessa construção, foi compreendida a necessidade de construção de um mundo anti-lesbofóbico e, também, não heteronormativo, antirracista, anticapitalista, anti-xenofóbico, anticapacitista, pois a existência lésbica perpassa por interseções de raça, classe, território, religiosidade, corpo, dentre outros marcadores. Além disso, foi ressaltada a importância de uma epistemologia, uma educação e leitura de teorias lésbicas a fim de difundir mais amplamente o pensamento lésbico. Assim, a Manifesta LésbicoFeminista traz uma manifestação coletiva de reivindicação por uma existência plural, diversa, visibilizada e que seja respeitada o seu direito de existir.

Nós, lésbicas e mulheres bissexuais potencializamos o momento de isolamento social em processos de formação política e acadêmica nos estudos das teorias lésbicas feministas, das lesbianidades e interseccionalidades. Por isso, escrevemos em coletividade essa manifesta, como reivindicação e proposta de um mundo não heteronormativo, não lesbofóbico, anticapitalista, antirracista, antixenofóbico, anticlassista e anticapacitista. Utilizamos a categoria "lésbica" enquanto um posicionamento político 
para além de uma orientação sexual, incluindo mulheres bissexuais e/ou mulheres que se identificam com mulheres afetiva, sexual e politicamente e que estejam engajadas com a transformação social.

Compreendemos que as pessoas podem ser o que quiserem, mas não é bem isso que a sociedade ainda baseada em preceitos patriarcais, racistas e misóginos apresenta. Consideramos que as pessoas devem ser livres das amarras da heteronorma, por isso, acreditamos em uma sociedade onde:

Todas as lésbicas e mulheres bissexuais, independente de raça/etnia, gênero, classe, escolaridade, geração, deficiências e orientação sexual têm a liberdade de ser o que quiserem, se relacionar, constituir famílias ou não, mas essas existências devem ser respeitadas. Assim como o Estado deve garantir políticas públicas que incluam as especificidades, sem enquadrar todas as pessoas como heterossexuais, especialmente quando não se performatiza os papéis de gênero ainda impostos.

Lutamos pelo reconhecimento da nossa existência, onde as práticas lésbicas não dizem simplesmente do campo do "privado" das relações sexuais, mas de uma visão da sociedade em que nossos corpos questionam a heteronormativade, seus requintes de crueldade baseados nas relações de parentesco e da propriedade privada, especialmente.

Independente da condição sexual, racial, étnica, de geração, de classe, de performance de gênero, somos políticas e construímos com nossa forma de estar no mundo, com questionamentos necessários para o respeito às expressões de nossas sexualidades. Somos símbolos de existência e resistência!

Questionamos as normas e nossos corpos não serão mais silenciados! Assim como as nossas escritas. Nós existimos e resistimos!

Aqui reverenciamos mulheres que vieram antes de nós e pensaram uma epistemologia lésbica feminista, radical e política de transformação da sociedade: Safo, Adrienne Rich, Monique Wittig, Gayle Rubin, Jules Falquet, audre lorde, Cheryl Clark, Ochy Curiel, dentre tantas outras.

Nossas saudações a todas que constroem suas experiências para a epistemologia lésbica feminista, antirracista e de transformação da sociedade.

Através desta manifesta, evidenciamos todas as formas de expressões das lesbianidades como um dos elementos na nossa formação política, acadêmica e pessoal. 
Nós temos o direito de expressar nossas sexualidades, independente da fase que aconteça. Para isso, se faz necessário uma educação sexual nas famílias, nas instituições públicas e privadas, que reconheçam e respeitem as orientações sexuais, para além da heteronormatividade.

Temos ciência das atrocidades que ainda persistem em nossa sociedade, quando vemos nossas irmãs sendo oprimidas e violentadas. Dói em nossos corpos, porque muitas vezes somos estas irmãs. Estamos sempre sentindo como é viver numa sociedade na qual somos vulneráveis, apesar de muito fortes. Lutamos por aquelas que precisam de nós, porque antes tiveram aquelas que lutaram por nós. Com o pensamento amparado nelas seguimos, como audre lorde diz: "Eu não serei livre enquanto houver mulheres que não são, mesmo que suas algemas sejam muito diferentes das minhas". Esta manifesta também é um chamado para que mais mulheres se incluam na luta, independente do lugar de fala, para transformação da sociedade.

O amor entre mulheres é uma potência que transforma nossas existências, que em meio as nossas complexidades, singularidades, somos resistentes e desafiamos cotidianamente a proibição institucionalizada do amor entre mulheres.

Compreendemos que esta manifesta parte de uma educação questionadora e transformadora que contemple nossas pluralidades. Reivindicamos uma educação antirracista, anti-LGBTfobia, anticapitalista. Uma educação interseccional que leve em consideração as questões ambientais, os saberes tradicionais de terreiros, aldeias e quilombos.

Compreendemos que muito se avançou. No entanto, precisamos deixar evidente que existe um fazer epistêmico lésbico e político, que precisa sair das gavetas dos gabinetes, dos repositórios e ganhar o mundo, as ementas. Nossas produções tem um ponto de vista lésbico feminista, interseccional, antirracista. Sobretudo, temos o compromisso político da geopolítica, de evidenciar nossas publicações e deixar nítido que não se trata "apenas" de uma relação sexual que vai passar, porque tem o mito que seremos salvas pela heteronormatividade. Não precisamos de salvação! Somos militantes, pesquisadoras, comprometidas a analisar a sociedade a partir das sexualidades, dentre ela, as lesbianidades, a partir dos pontos de vista lésbico feminista, sapatão, interseccional, antirracista.

Vamos ler teóricas lésbicas nas universidades brasileiras, latinoamericanas, dos movimentos. Leiam as lésbicas que escrevem sobre lesbianidades 
em suas diversas expressões. Optamos por finalizar essa manifesta com um trecho da poesia de Raquel Berenguer intitulado "Espalhando Sementes", como um convite a todas as lésbicas, mulheres bissexuais e das diversas lutas. Juntem-se a nós e vamos construir mais resistências, epistemologias, atos políticos e revolucionários do amor entre mulheres, em suas diversas esferas.

"Assim, quem sabe um dia juntem-se a nós mais duas mulheres, que semeiam, mais dez mulheres, que plantam, mais cem mulheres, que colhem."

06 de dezembro de 2020 . 


\title{
MANIFESTO TRAVESTI
}

\author{
Sara Wagner York \\ Bruna Benevides \\ Megg Rayara Gomes de Oliveira
}

Quando nos aproximamos da própria ideia de um manifesto, encontramos algumas definições preliminares como, por exemplo: 1) ser uma declaração trazida a público; 2) ser uma declaração solene de um partido, um grupo religioso, ou, ainda, de artistas; 3) possuir relações de bens para efeitos fiscais; 4) documento que não pode ser contestado ou oculto; 5) adjetivo para aquilo que se revela por sua evidência. Nestas definições que podemos localizar de forma mais ou menos elaboradas, em diversos dicionários encontramos elementos políticos, religiosos e artísticos, mas, também, elementos jurídicos, legais e burocráticos.

Desta forma, quando nos aproximamos da composição de um manifesto travesti devemos remontar, também, à linha dura e à linha de fuga de um manifesto. A linha dura trata do manifesto ser um elemento do poder do soberano (FOUCAULT, 1988) ${ }^{63}$. O soberano manifesta a sua vontade intenções e leis - para os seus súditos. Não obstante, ainda hoje, a definição de manifesto tem no seu lastro uma questão burocrática e prescritiva. A linha de fuga é a própria usurpação da autoridade soberana. Neste momento poderíamos pensar numa prática que definiu o próprio pensamento queer. Trata-se da subversão dos métodos, da reapropriação dos termos, do roubo criativo de ideias e da extrema antropofagia: um pensamento Travesti.

\footnotetext{
${ }^{63} \mathrm{O}$ direito é formulado na vida e na morte; de causar a morte ou de deixar viver. O Poder Soberano, antes de tudo, é o direito de apreensão do tempo, dos corpos e, finalmente, da vida. O ponto máximo desse poder é o privilégio de se apoderar da vida para depois, caso assim o desejasse, suprimi-la (FOUCAULT, 1988). O texto na íntegra foi lançado em dezembro /2020 pela Scielo com nome Manifestações textuais (insubmissas) travesti uma vez que a Scielo e seu editor nesta produção pediram a retirada/substituição da palavra manifesto, na justificativa nos informaram que a revista não publica Manifestos! e consta em: https://www.scielo.br/scielo.php?script=sci_ arttext\&pid=S0104-026X2020000300501\&lng=pt\&nrm=iso\&tlng=pt
} 
A respeito da palavra travesti, há uma potente significação, por vezes torpe do verbo, travestir. Seja "travestir" na tentativa posta que em dado momento vincula à sujeira, à doença, a marginal, à maleficência disfarçada, falseada, não genuína. Para nós, por sua vez, a palavra se vincula à luta, à resistência, à dignidade e a uma potencialidade política e contestatória. Uma palavra feminina, um substantivo feminino e nunca um verbo que sujeita e infere. Corriqueiramente, e de forma equivocada, pessoas cisgêneras utilizam a palavra travesti enquanto verbo com desinência de tempo passado, para atribuições de cunho pejorativo, como na frase, "o político, fulano de tal, estava travestido de aliado". Travestido, judiado, denegrido e tantas outras formas que a língua adere à norma ao passo que pune. Quem determina os limites possíveis de se existir enquanto travesti e ter uma experiência de vida que surge impregnada de estigmas e tabus, violência, invisibilidade e negação de espaços?

É desta linha de fuga na palavra do soberano que nos aproximamos. Assim, lembramos que o manifesto, enquanto um gênero literário, traz a sua potência neste aspecto. Alinhamo-nos ao manifesto em produção textual múltipla, pois propõe outras relações éticas, estéticas e de afetos. Esta produção múltipla do manifesto é marcada por uma posição política dentro de uma determinada conjectura cultural e política, e incide com certa urgência. Esta urgência do manifesto nos faz abarcar a atualidade na sua forma mais convulsa, contemporânea, plena em agora.

A celeridade das ações necessárias nos evoca o presente e o cotidiano, mas também uma perspectiva para abertura de futuros possíveis. Neste sentido, o manifesto é uma escrita que intensifica o agora. Ele é feito para que haja possibilidade de mudanças e tensionamentos futuros. A trilogia queer dos manifestos talvez pudesse ser nomeada com: 1) 0 manifesto Ciborgue, de Donna Haraway (1994); 2) Manifesto contrassexual, de Paul B. Preciado (2017); e 3) Manifesto Gaga, de Jack Halberstam (2012). É evidente que em cada um destes manifestos há suas especificidades e o seu contexto de produção, porém, em todos eles há um programa e uma tentativa de quebrar determinadas barreiras político-epistêmicas, como assim também o é o próprio Manifesto.

Ao contrário do imaginário do senso comum, ser uma travesti é o reconhecimento de um outro corpo possível, legítimo, além daquele normatizado. É a constituição de uma identidade real (quando apresenta 
materialmente seu corpo), social (quando transita entre os espaços) e política (quando reivindica direitos - de fato e de direito). Essa mesma identidade social, que é produtora de cultura, rompe com os signos binários estáticos e expressa-se como pertencente ao gênero feminino. A disruptura às normas sociais, ao longo da história, colocava as travestis às margens sociais, expondo ou naturalizando práticas de violência (estrutural, simbólica, patrimonial, psicológicas e físicas), além da exclusão social comumente praticada por parte da população contra nós.

O direito à autodeterminação delibera a todos os corpos (cis/trans) a possibilidade da autonomia sobre a escolha em retificar nome e gênero e, com isso, uma vez mais experienciam a adequação à norma como única forma de inserção cível e acesso às políticas públicas. Nos adequamos para sobreviver. Assim, aquelas que decidiram não emergir para uma vida "fora do armário" seguem em sua travestilidade, transexualidade ou transvestigeneridade, gozando de direitos ou confortos que deveriam operar sobre todas.

Neste momento, não se trata de uma narrativa solta, mas de enfatizar alguns elementos do próprio exercício de escuta da "voz" travesti. Escutas atentas e outrora feitas por outros vieses que construiriam um arquivo ou banco de memórias para desenho de uma epistemologia e, neste caso, uma trans-epistemologia. A consequência lógica apresentada é que, se existem dispositivos ${ }^{64}$ para a não escuta destas histórias, assim estamos diante de um trans-epistemicídio. Via de regra, as incursões etnográficas feitas por pesquisadoras e pesquisadores brasileiras e brasileiros destacam a presença de travestis e mulheres transexuais em "bairros de periferia, boates, praças, pensões e territórios de prostituição” (SANTOS et. ali., 2014, p. 302), raramente no campo do conhecimento, especialmente o acadêmico.

O preconceito que surge como principal obstáculo de travestis e transexuais até a graduação ganha uma outra forma nos programas de mestrado e doutorado. Nesse ambiente, as poucas pesquisadoras trans sofrem questionamentos velados quanto à sua isenção, especialmente quando estudam o universo LGBT (SABÓIA, 2018).

\footnotetext{
${ }^{64}$ Todos os Dispositivos são Dispositivos de Poder e procuram atribuir ao corpo alguma utilidade e permitem o controle minucioso de suas ações e asseguram a sujeição constante de suas forças e lhe impõem uma relação de docilidade-utilidade (FOUCAULT, 1979).
} 
No caso da explicitação do corpo travesti e suas histórias, podemos pensar em estratégias que desestabilizam a voz travesti antes mesmo de ela falar ou emitir qualquer ruído. Trata-se de palavras como: vitimismo, coitadismo e denuncismo. É possível que encontremos palavras correlatas, mas, são estas três, que, na atualidade, criam um muro na escuta da voz travesti, sendo uma das faces de operação da transfobia.

Estamos diante da interpelação de Gloria Anzaldúa (2005) e sua autohistória teórica. É possível observar os limites e borrões entre a descrição de histórias de vidas enquanto elaboração de um quadro em movimento que a todo tempo pergunta quem é travesti, quem é trans e o que seria drag? 0 que as difere? Quem pode dizer: tire a barba para ser mulher? Quem pode determinar a quantidade de maquiagem sobre a pele que um corpo travesti apresenta? Quem pode dizer a alguém que ela não é travesti, senão ela mesma? Quem pode autoidentificar alguém? Mas é fato que algumas de nós, por seguirem exotificadas (KILOMBA, 2019) seremos arremessadas aos ritos do super-humano ou sub-humano, qualidade sentida por travestis ao serem retratadas como divas dos palcos ou como abjetas e SIDAdãs (PELUCIO, 2009) de segunda classe em um mundo de diverCISdade.

Por muitas vezes, cruzando fronteiras de sentimentos intensos e múltiplos meandros, a travesti que ganha o concurso de Miss é a mesma que está desempregada e é obrigada a recorrer (muitas vezes) à prostituição e à noite para garantir sua subsistência, e não há nada errado nisso, desde que essa não seja a única opção. O posicionamento diante de complexidades tão fronteirísticas erroneamente ganham conotação pejorativa, principalmente, numa compreensão cis-fálica-sexista (SUSSEKIND; YORK; CARMO, 2020). Esta compreensão cis-fálica-sexista (SUSSEKIND, YORK, CARMO, 2020), que engendra regimes de verdade (FOUCAULT, 2010, p. 67), é a própria produção destes epistemicídios já salientados em escritos folclóricos e com recortes precisos nos elaborados de muitos narradores e sua visão de diverCISdade.

Estas noções difusas de vitimismo, coitadismo e denuncismo que surgem diante de qualquer storytelling desconhecem a própria vivência travesti em sua radicalidade. Os processos de violência e vulnerabilização experienciados pela população travesti são tão apavorantes, que apenas os 
dados gerais como mortes ${ }^{65}$ e torturas ganham um pouco de atenção por parte da mídia e do grande público - em um grande circo de horrores que denuncia a estrutura sistêmica de exclusão e exotificação de seus corpos mutilados, muitas vezes desnudos para lembrar que aquele corpo não deveria existir ou ser aceito como humano.

A veiculação exaustiva, nas redes sociais, do corpo trucidado da travesti negra Verônica Bolina por meio de imagens que habitam o campo do abjeto levanta questionamentos sobre esse mecanismo de denúncia (BORGES, 2015). A morte ritualizada, como aconteceu com Dandara, em Fortaleza, em 2017, ganha contornos de espetacularização. "Não basta um tiro fatal, ou uma facada precisa ou um atropelamento definitivo. Os corpos são mutilados por dezenas de facadas, por inúmeros tiros. Os corpos são desmembrados pelo peso do carro que o atropela várias vezes" (BENTO, 2014). Esses rituais revelam "um desejo social de eliminação da existência trans com a conivência do Estado brasileiro" (BENTO, 2014).

Enquanto travestis, dormimos crianças e (raramente) adolescentes (sendo que a adultização de nossos corpos, muitas vezes, nos impede de acessar a adolescência) e em um passe de mágica, ao dizermos algo que relacione o desejo físico ao corpo, até então lido como homoerótico, em questão de segundos, nos tornamos adultas maliciosas. Pervertidas.

Trata-se de explicar, com este conceito, tanto uma história que antecede o corpo (trans) generificado(r) da travesti, quanto o exercício do abandono de um "si mesmo" por longos períodos de tempo, dado o exercício constante do esforço resistente frente à transfobia instaurada por um Estado aniquilador ${ }^{66}$. Este segundo elemento é sentido de forma recorrente por pessoas de situação de rua, usuárias de drogas e travestis. É a dor do abandono por outros e, por algum momento, por si.

\footnotetext{
${ }^{65}$ Para saber mais, consultar Relatório Completo de Assassinatos de Travestis e Transexuais da Antra. Disponível em https://antrabrasil.org/assassinatos/.

${ }^{66}$ Um Estado que dificulta e, em muitas situações, impede que travestis se constituam como sujeitas de direito. Essas situações se materializam quando a anatomia biológica se sobrepõe à identidade de gênero, minando o acesso a direitos essenciais como educação, saúde, segurança, dentre outros, aniquilando, concretamente, a possibilidade de ser vista e reconhecida como pessoa. Assim, "da mesma forma que a sociedade precisa de modelos exemplares, de heróis, os não exemplares, os párias, os seres abjetos também são estruturantes para o modelo de sujeitos que não devem habitar a nação" (BENTO, 2014).
} 
Diante de violências, em um primeiro momento somos levadas a crer que nestes casos seria necessária uma denúncia. Mas para a população travesti, onde falar não é permitido e reinvidicar um direito lhe é negado, a denúncia não é uma opção capaz de ser ouvida ou levada a sério por parte de muitos agentes que ocupam instâncias públicas de atendimento. Se faz recorrente uma leitura subsequente que termina por ser nomeada de coitadismo e seu praticante o vitimista. Não se trata apenas de apontar o problema (denúncia), mas abri-lo como um chamado de ajuda e construção de uma resposta, onde quem critica não apresenta resposta, mas exige da própria vítima uma solução-resposta ${ }^{67}$.

Exigir da vítima uma resposta seria uma forma de colocá-la em situação de revitimização, que compreende negligência, imperícia ou omissão, afastando a possibilidade de que ela se sinta capaz de seguir em frente na reivindicação do que parece algo simples para um olhar cisgênero desatento. Esquecendo que o alvo que ela carrega, após uma denúncia, se torna ainda maior, pois esta ousou se apropriar de uma ferramenta que não foi pensada para ela. E que, por isto, não seria um direito seu usar da denúncia para qualquer reparação pelo mal que lhe acometera, visto que o processo de exigir respostas dela enquanto vítima a coloca como culpada por aquilo que Ihe aconteceu. A pergunta que é feita à vítima ainda é "o que você fez para que isso acontecesse?".

O fator revitimizador acontece quando pessoas em situação de vulnerabilização precisam responder a questões que são agudas ao tratarmos de agressão, de mesmo modo a constante nuvem da violência simbólica naturalizada contra a travesti ao negligenciarem seu gênero ou o pronome correto no tratamento/atendimento. Perguntas de caráter agressor (feitas por instâncias estatais ou não) e que gerem danos ou sofrimento à vítima em função de negligência, afirmação, ou imperícia cometido pelo agente do estado, naquele momento que gere a potencialização da dor, consequência negativa ou sofrimento para a vítima ${ }^{68}$.

Muitas denúncias envolvendo pessoas trans terminam sendo desencorajadas e sistematicamente não investigadas, inconclusivas

\footnotetext{
${ }^{67}$ Jaqueline Gomes de Jesus, em áudio a partir do grupo on-line "TRANSacadêmicas", no dia $11 / 03 / 2019$.

${ }^{68}$ Artenira Silva, Professora e Doutora em Psicologia, cuja área de estudo envolve vítimas atendidas pela lei Maria da Penha. Em conversa via WhatsApp a partir do grupo on-line "Políticas TRANS BR".
} 
ou ignoradas (ANTRA, 2019). São corriqueiras tais situações na vida das travestis que têm suas existências negadas enquanto cidadãs. E quando falamos daquelas que estão expostas nas ruas, em sua maioria negras, cujo destino ainda é a prostituição, cogitar a efetivação de uma denúncia seria uma escolha entre lidar com descaso no atendimento, na reivindicação do direito, ou ainda enfrentar o risco de se colocar novamente em situação de hiperexposição, quando ainda vemos agentes do estado sendo responsáveis por diversas violências e violações.

Como ela poderia denunciar ao estado o seu próprio agente, e exigir proteção, ou que o mesmo estado cuide de sua segurança? Como ela poderia denunciar um assalto ou calote de um possível cliente, se no momento do registro de ocorrência vale mais a palavra do "cidadão de bem" que tem voz, e que se negou a pagar seu programa, e a acusa de tê-lo tentado assaltar invertendo a situação, reforçando estigmas e se livrando assim de ter exposta sua sexualidade maculada pela descoberta do prazer em sair com uma travesti? Como ela poderia denunciar um agente do estado ou um cidadão de bem, e no momento seguinte voltar às calçadas, exposta àqueles que jamais deveriam ser apontados por alguém como ela?

Perceba que em um único dia a mesma travesti desejada e olhada "de cima a baixo" pode ser apontada por pessoas nas ruas como objeto de chacota, tratada com desdém ou acusada de "atrevida ou escandalosa" se for questionadora da suposta autoridade moral de algum opressor. Daniela Andrade ${ }^{69}$, em sua página no Facebook, diz que "um dia travesti aos corpos cisheteros já seria o suficiente para mudar o número de travestis mortas nas estatísticas".

O que pode ser percebido é a existência de uma legalidade nas ações objetivadas e a transfobia estrutural por parte de uma sociedade, e governo, com características heterocentradas e cisnormatizadas que insistem, desde a década de 1970, com a ajuda do aparato policial, que "pôs em curso um processo de higienização e caça [...] às travestis na tentativa, pouco produtiva, de eliminar, simbólica e fisicamente, esses desviantes de "sexogênero" (VIEIRA, 2015).

\footnotetext{
${ }^{69}$ Daniela Andrade é Trans-ativista e utiliza diariamente sua página no Facebook para apresentar seus posicionamentos ético-políticos se tornando, desde então, digital influencer, a partir de seus posicionamentos pouco ortodoxos em maio de 2018.
} 


\section{Programa: um ato manifesto}

"̛⿱ Não falem de nossos nós, por nós e/ou sem nós!

Jamais use o poder do conhecimento como arma e contra um corpo ou um grupo tão deslegitimado como o nosso, de travestis! Muitas escolhas são políticas e questioná-las é validar-nos como menores ou incapazes de saber, decidir e conhecer a história.

"̛̃ Não hierarquizem nossas identidades (todas são formas de acesso às políticas públicas). Travestis, mulheres transgêneras e mulheres transexuais são identidades transvestigeneres que devem ser tratadas com igual respeito (sendo fixas em muitas existências perpetuadas ou devires em tantas outras).

Não existe uma única forma de ser travesti. Temos diversas travestilidades e possibilidades de ser travesti. Nenhuma é igual a outra (o experimento da expressão de gênero pode ou não ser constitutivo); não generalize.

"̧ Nossa transcestralidade importa (e se não soubermos de nossess/os/ as antepassades/os/as, explique sem nos hierarquizar)!

Representatividade importa se pressupor compromisso social, senso de coletividade, compromisso com a transfomação e ruptura das estruturas transfóbicas e de exclusão.

Nome social é uma política importante para travestis (que não querem ou não podem mudar de nome). Respeite nossa singularidade!

Reveja os aspectos gramaticais em sua fala/escrita e pense o quanto a língua portuguesa falada e/ou escrita contempla pessoas binárias masculinas. A língua é viva e como nossa cultura, ela também está mudando, transvestigenere-se! Inclua todes outres sujeites!

"̧ Travestis podem ter filhes/os/as (ou não) e constituir família (se desejarem).

Wão quer ter uma filha travesti, não tenha filhos. As chances de ter uma filha trans é a mesma de ter um/a/e filho/a/e destro/a/e ou canhoto/a/e. Acolham as crianças trans e travestis, é nesse momento que mais precisamos de apoio. 
\%马 0 gueto foi/é importante para nós. Ali aprendemos a nos ajudar e nos compreender como seres coletivos. Parem de ignorar ou sugerir que nossos "quilombos" não tiveram importância para a nossa sobrevivência.

Sobrevivemos à epidemia do HIV. Somos filhas da AIDS. Netas da Violência. E hoje queremos mais (em terra Brazilis, quem perdoa é Jesus!), queremos reparação histórica, já!

\% Prostituição não é crime no Brasil, poderia ser uma opção para muitas de nós, mas numa sociedade justa não podemos suportar que qualquer pessoa esteja nesta profissão enquanto destino compulsório, inicial e final de sua existência.

Viveremos e as nossas trans-epistemologias também! (com sua inconsciência ou isenção diante dos nossos temas e demandas).

"' Contrate uma Travesti. Ajude em sua formação e qualificação. Pague por consultoria quando precisar de uma travesti para escrever sobre nós.

\$' Façam eventos, propagandas, filmes, peças ou qualquer coisa sobre nós, desde que haja travesti(s) participando efetivamente na equipe.

\%esquisas: alimente a política da inserção, podemos escrever juntas/ os/es/xs. Respeite o lugar de fala - fale a partir do que lhe toca e como the toca - isso significa ir além e (re)pensar (a sua pesquisa, seu objeto) seu olhar sobre a vida.

Não fetichizem nossos corpos. O país que mais acessa pornografia trans/travesti é o mesmo país que ainda discute casamento homoafetivo e enxerga trans/travestis como extensão de orientação sexual.

Não somos violentas. Esse discurso alimenta os processos de exclusão das travestis dos espaços sociais, ainda que nossa "docilidade" fosse ensinada nas escolas, em nossas famílias e sociedade. Chega de "dar a outra face"!

\% 0 sorriso e o bom gosto sempre foram uma marca travesti de sobrevivência, mas estamos além das baladas, somos os sorrisos nas redes sociais, mas exigimos responsabilidade social com as causas que nos visibilizam. Vivemos antes, agora e no futuro, oportunizar um agora é construir um futuro possível e menos violento e, quem sabe, um dia de paz. 


\section{REFERÊNCIAS}

ANDRADE, Luma Nogueira de. Travestis na escola: assujeitamento e resistência à ordem normativa. 2015. Tese (Doutorado em Educação). Universidade Federal do Ceará, 2012.

FOUCAULT, Michel. Microfísica do poder. Rio de Janeiro: Graal, 1979.

FOUCAULT, Michel. O governo de si e dos outros. 2010.

HALBERSTAM, Jack. Gaga feminism. Estados Unidos: Beacon Press Books, 2012.

GONÇALVES Jr, Sara Wagner Pimenta. Corpos transgressores: Politicas de resistências. Campinas-SP. Pontes. 2018.

GONÇALVES Jr, Sara Wagner Pimenta. As (Trans)Alianças e a Neomaquinaria https://www. cartacapital.com.br/justica/as-transaliancas-e-a-neomaquinaria/ Acesso em 27 julho 2020.

JESUS, Danie Marcelo de; MELO, Glenda Cristina Valin de; TCHALIAN, Vicente; GONÇALVES Jr, Sara Wagner Pimenta. Corpos transgressores: Politicas de resistências. Campinas-SP. Pontes. 2018.

HARAWAY, Donna. Manifesto ciborgue: ciência, tecnologia e feminismo-socialista no final do século XX. In: SILVA, Tomaz Tadeu da (Org.). Antropologia do ciborgue. Belo Horizonte: Autêntica, 2000.

KOPENAWA, D.; ALBERT, B. A queda do céu: Palavras de um xamã yanomami. São Paulo: Companhia das letras, 2015

LEOPOLDO, Rafael. Cartografias do pensamento queer. (No prelo)

LEOPOLDO, Rafael. Tango, o baile dos corpos dóceis, 2019.

MBEMBE, Achille. Necropolítica. São Paulo: N -1 Edições, 2019. 


\section{SOBRE OS(AS) AUTORES(AS)}

Abayomi Jamila (pseudônimo literário de Daiane Silva Santos)

Mestranda no Programa de Pós-Graduação em Educação, membro do Grupo de Estudos Infância, Juventude e Cultura Contemporânea (GEIJC) e graduada em Psicologia pela Universidade Federal de Mato Grosso (UFMT/ Câmpus Rondonópolis). É idealizadora e produtora cultural do campeonato de poesia falada SLAM Circuito Marginal e criadora do ITAN Selo Literário, em Mato Grosso. E-mail: abayomi.jamila@gmail.com.

\section{Alexsandro Rodrigues}

Doutor em Educação pela Universidade Federal do Espírito Santo (UFES). Pós-Doutorado em Psicologia pela Universidade Federal Fluminense (UFF). Professor do Departamento de Teorias e Práticas Educacionais e do Programa de Pós-Graduação em Psicologia Institucional da UFES. Coordenador do Núcleo de Estudos e Pesquisas em Sexualidades (NEPSs) da UFES. Email: xela_alex@bol.com.br.

\section{Amanda Bravo Pereira Almeida}

Graduanda em Psicologia pela Universidade Federal de Rondonópolis (UFRMT). Membro do Laboratório Esquizoanalista de Produção de Subjetividades e(m) Interseccionalidades (LEPSI). E-mail: amandabpa1@gmail.com.

\section{Ana Paola de Souza Lima}

Doutora e Mestra em Estudos da Linguagem pelo Programa de Pós-graduação em Estudos da Linguagem da Universidade Federal de Mato Grosso (PPGEL) UFMT). Graduada em Letras (Português e Inglês) pelo Centro Universitário de Várzea Grande (UNIVAG). Graduada em Ciências Contábeis pela UFMT. Atua como professora e vice-coordenadora pedagógica no Centro de Línguas da Universidade Federal de Rondonópolis (CELIG/UFR-MT). Professora do Departamento de Letras (Inglês) da UFR. E-mail: anapaoladesouzalima@ gmail.com.

\section{Benjamin Braga Neves}

Doutor em Educação pela Universidade do Estado do Rio de Janeiro (UERJ), doutorando em Estudos de Cultura Contemporânea pela Universidade Federal de Mato Grosso (UFMT), Mestre em Ciências e Especialista em Gênero e Sexualidade pela UERJ. Pesquisador dos grupos GENI (UERJ) e GELTED (UFMT) e do Instituto Brasileiro de Transmasculinidades (IBRAT). Email: benjamimbraga1@gmail.com 


\section{Brendhon Andrade Oliveira}

Mestrando em Direito pelo Programa de Pós-Graduação em Direito da Universidade Federal de Mato Grosso (PPGD/UFMT). Membro do Núcleo de Estudos e Pesquisas sobre a Organização da Mulher e Relações de Gênero NUEPOM/UFMT. E-mail: andradebrendhon@gmail.com.

\section{Bruna Andrade Irineu}

Assistente Social, Mestre em Sociologia pela Universidade Federal de Goiás (UFG) e Doutora em Serviço Social pela Universidade Federal do Rio de Janeiro (UFRJ). Professora do Departamento de Serviço Social e do Programa de Pós-Graduação em Política Social da Universidade Federal de Mato Grosso (PPGPS/UFMT). Coordenadora do Núcleo de Estudos e Pesquisas sobre as Relações de Gênero (NUEPOM/UFMT). Presidente da Associação Brasileira de Estudos da Homocultura (ABEH) e editora-chefe do periódico REBEH. E-mail: brunairineu@gmail.com.

\section{Bruna Benevides}

Marinha do Brasil, Niterói, RJ, Brasil. Secretária de Articulação Política da Associação Nacional de Travestis e Transexuais (ANTRA). Secretária de Comunicação da Associação Brasileira de Lésbicas, Gays, Bissexuais, Travestis, Transexuais e Intersexos (ABGLT). Membro da Rede Nacional de Operadores de Segurança Pública LGBTI+ (RENOSP LGBTI+). Email: bnrj.secom@marinha.mil.br.

\section{Dandara Felícia Silva Oliveira}

Bacharel em Gastronomia, bacharelanda em Ciências Sociais e mestranda do Programa de Pós-Graduação em Serviço Social da Faculdade de Serviço Social da Universidade Federal de Juiz de Fora (UFJF). Pesquisadora do GEDIS/ CNPq e do CeR-LGBTQI+ da UFJF. Travesti preta e primeira suplente do PSOL na Câmara de Vereadores de Juiz de Fora. E-mail: dandaradoxum@gmail.com.

\section{Dani Lebinski}

Pseudônimo de uma professora de Literatura de uma escola pública paulista. Bissexual, formada em Letras pela Universidade Estadual do Centro-Oeste (Unicentro). Escritora amadora e apaixonada por escrever e sentir a poesia. E-mail: sentindoapoesia@gmail.com.

\section{Danie Marcelo de Jesus}

Mestre em Educação pela Universidade Federal de Mato Grosso (UFMT/ Câmpus Cuiabá) e doutor em Linguística Aplicada e Estudos da Linguagem pela Pontifícia Universidade Católica de São Paulo (PUC-SP). Professor associado I do curso de Letras; orienta no Programa de Pós-graduação em Estudos de 
Linguagem e no Programa de Pós-Graduação em Estudos da Cultura da UFMT/ Câmpus Cuiabá. E-mail: daniepuc@gmail.com.

\section{Francis de Lima Aguiar}

Cronista. Poeta. Professor de Literatura em uma escola pública no interior do Paraná. Mestre em Letras pelo Programa de Pós-Graduação em Letras Estudos Literários da Universidade Estadual de Londrina (UEL-PR). E-mail: aguiarofrancis@gmail.com.

\section{Guilherme Rodrigues Passamani}

Graduado em Ciências Sociais e História pela Universidade Federal de Santa Maria (UFSM). Mestre em Integração Latino-Americana pela UFSM. Doutor em Ciências Sociais pela Universidade Estadual de Campinas (UNICAMP). Professor do Programa de Pós-Graduação em Antropologia Social da Universidade Federal de Mato Grosso do Sul (PPGAS/UFMS) e Estudos Culturais (PPGCult/UFMS). Coordenador do Núcleo de Estudos Néstor Perlongher - Cidade, Geração e Sexualidade (NENP/UFMS). Atualmente é Doutorando em Antropologia no ISCTE-IUL em associação com a Universidade NOVA de Lisboa. E-mail: guilherme.passamani@ufms.br.

\section{Jaqueline Gomes de Jesus}

Professora de Psicologia do Instituto Federal do Rio de Janeiro (IFRJ). Docente permanente do Programa de Pós-Graduação em Ensino de História da Universidade Federal Rural do Rio de Janeiro (UFRRJ). Doutora em Psicologia Social do Trabalho e das Organizações pela Universidade de Brasília (UnB), com pós-doutorado pela Escola Superior de Ciências Sociais da Fundação Getúlio Vargas (CPDOC/FGV). Pesquisadora-Líder do ODARA - Grupo Interdisciplinar de Pesquisa em Cultura, Identidade e Diversidade. Coordenadora do Núcleo de Diversidade - NDIVAS Marielle Franco (IFRJ/ Câmpus Belford Roxo). E-mail: jaqueline.jesus@ifrj.edu.br.

\section{Jefferson Adriã Reis}

Licenciado em Letras (Português) pela Universidade Federal de Mato Grosso (UFMT/Câmpus Rondonópolis). Graduando em Psicologia pela Universidade Federal de Rondonópolis (UFR-MT). Membro do Laboratório Esquizoanalista de Produção de Subjetividades e(m) Interseccionalidades (LEPSI). Blog: https:// jeffersonadriareis.com. E-mail: jeffersonadriareis@gmail.com.

\section{Joe Sales}

Professor rondonopolitano de Língua Portuguesa, poeta, escritor, colunista na revista Ruído Manifesto e professor supervisor na Universidade Estadual do 
Mato Grosso (UNEMAT). Mestre em Estudos de Linguagem pela Universidade Federal de Mato Grosso (UFMT/Câmpus Cuiabá), atualmente desenvolve o projeto de leitura: "Leituras Clandestinas", que é fruto de seu primeiro livro de contos “Clandestinamente”. E-mail: jodaliteratura@gmail.com.

\section{Jônatas Stritar Alaman}

Graduado em Ciências Sociais pela Universidade Federal de Mato Grosso do Sul (FACH/UFMS). É membro do Núcleo de Estudos Néstor Perlongher cidade, geração e sexualidade (NENP/UFMS), onde desenvolveu pesquisas sobre prostituição masculina.E-mail: jonatasalaman5@gmail.com.

\section{Késia Mayra Rodrigues Ignácio}

Psicóloga e mestranda do Programa de Pós-Graduação em Serviço Social da Faculdade de Serviço Social da Universidade Federal de Juiz de Fora (UFJF). Pesquisadora do GEDIS/CNPq da UFJF. Integrante da Frente Preta da UFJF. E-mail: kesiaarodriguesi@gmail.com.

\section{Lissa Carvalho de Souza}

Graduanda em Psicologia pela Universidade Federal Rondonópolis (UFR-MT). Membro do Laboratório Esquizoanalista de Produção de Subjetividades e(m) Interseccionalidades (LEPSI).E-mail: lissacarvalhosouza@gmail.com.

\section{Lorena Lopes de Oliveira}

Psicóloga pela Universidade Federal de Mato Grosso (UFMT/Câmpus Rondonópolis). Membro do Laboratório Esquizoanalista de Produção de Subjetividades e(m) Interseccionalidades (LEPSI). Residente no Programa Multiprofissional em Saúde da Família da Universidade Federal de Rondonópolis (UFR-MT). E-mail: lorenaloopess@gmail.com.

\section{Marcelo Victor da Rosa}

Graduado em Licenciatura em Educação Física pela Universidade Federal de Santa Catarina (UFSC). Mestre em Educação Física (UFSC). Doutor em Educação pela Universidade Federal de Mato Grosso do Sul (UFMS). Professor do Programa de Pós-Graduação em Estudos Culturais (PPGCult/UFMS). Professor da Faculdade de Educação (UFMS). Pesquisador do Núcleo de Estudos Néstor Perlongher - Cidade, Geração e Sexualidade (NENP/UFMS). E-mail: marcelo. rosa@ufms.br. 


\section{Márcio Alessandro Neman do Nascimento}

Psicólogo (Bacharelado, Licenciatura e Formação de Psicólogo) pela Universidade Estadual de Londrina (UEL-PR). Doutor e mestre em Psicologia e Sociedade: Subjetividade e Saúde Coletiva pelo Programa de Pós-Graduação da Universidade Estadual Paulista - Júlio de Mesquita Filho (UNESP/Campus Assis-SP). Professor adjunto do curso de Psicologia da Universidade Federal de Rondonópolis (UFR-MT). Coordenador do Laboratório Esquizoanalista de Produção de Subjetividades e(m) Interseccionalidades (LEPSI). E-mail: marcioneman@gmail.com.

\section{Marco José de Oliveira Duarte}

Assistente Social, Mestre e Doutor em Serviço Social e Pós-doutor em Políticas Sociais. Professor Adjunto da Faculdade de Serviço Social e do Corpo Permanente do Programa de Pós-Graduação em Serviço Social da Universidade Federal de Juiz de Fora (UFJF). Professor Colaborador do Programa de PósGraduação em Serviço Social da Universidade do Estado do Rio de Janeiro (UERJ). Pesquisador do Conselho Nacional de Desenvolvimento Científico (CNPq). Coordenador do Grupo de Estudos e Pesquisas em Sexualidade, Gênero, Diversidade e Saúde: Políticas e Direitos (GEDIS/CNPq) e do Centro de Referência LGBTQI+ (CeR-LGBTQI+) da UFJF. E-mail: majodu@gmail.com.

\section{Marcos Aurélio da Silva}

Professor do Instituto de Saúde Coletiva (ISC), do Programa de Pós-Graduação em Saúde Coletiva e do Programa de Pós-Graduação em Antropologia da Universidade Federal de Mato Grosso (UFMT). Pesquisador do NAPlus - Núcleo de Antropologia e Saberes Plurais. Email: marcoaureliosc@hotmail.com

\section{María Antonella Barone}

Formada em Psicologia pela Universidad Nacional de Córdoba (UNCArgentina). Mestra em Psicologia Institucional pela Universidade Federal do Espírito Santo (UFES). Doutoranda em Psicologia pela UFES. Pesquisadora pertencente ao Grupo de Estudos sobre Aborto (GEA), linha de pesquisa do Núcleo de Estudos e Pesquisas em Sexualidades (NEPSs) da UFES. Email: licenciadaantonellabarone@gmail.com.

\section{Maria Carolina Kovaleski Ferreira}

Graduanda em Psicologia pela Universidade Federal de Rondonópolis (UFRMT). Membro do Laboratório Esquizoanalista de Produção de Subjetividades e(m) Interseccionalidades (LEPSI). E-mail: mcarolkf@gmail.com. 


\section{Megg Rayara Gomes de Oliveira}

Professora do Programa de Pós-Graduação em Educação da Universidade Federal do Paraná (UFPR). Possui graduação em Licenciatura em Desenho (1994) e Especialização em História da Arte (1996) pela Escola de Música e Belas do Paraná. Mestrado em Educação pela Universidade Federal do Paraná (2012) e Doutorado em Educação pela Universidade Federal do Paraná (2017). É coordenadora do Núcleo de Estudos Afro-Brasileiros (NEAB) da Universidade Federal do Paraná. Email:meggrayaragomes@gmail.com.

\section{Milena Carlos Lacerda}

Doutoranda em Serviço Social pelo Programa de Pós-Graduação em Serviço Social da Universidade do Estado do Rio de Janeiro (UERJ). Professora do Curso de Serviço Social da Universidade Federal do Tocantins (UFT). Pesquisadora do Núcleo de Estudos, Pesquisa e Extensão em Sexualidade, Corporalidades e Direitos (UFT). E-mail: milenalacerdaseso@gmail.com.

\section{Moisés Alessandro Lopes}

Professor Associado do Departamento de Antropologia e do Programa de PósGraduação em Antropologia Social da Universidade Federal do Mato Grosso (UFMT). Graduado e Mestre em Ciências Sociais pela Universidade Estadual de Londrina (UEL-PR). Doutor em Antropologia pela Universidade de Brasília (UnB). Pós-Doutor em Antropologia Social pela Universidade Federal de Santa Catarina (UFSC). Integra o Instituto Brasil Plural (INCT/PPGAS/UFSC/UFAM); Membro da Comissão Municipal de Atenção à Diversidade Sexual de Cuiabá - MT; Coordenador do NAPlus - Núcleo de Antropologia e Saberes Plurais. E-mail:sepolm@gmail.com

\section{Pablo Cardozo Rocon}

Mestre em Saúde Coletiva e Doutor em Educação pela Universidade Federal do Espírito Santo (UFES). Professor do Instituto de Saúde Coletiva e do Programa de Pós-Graduação em Saúde Coletiva da Universidade Federal de Mato Grosso (UFMT/Câmpus Cuiabá). Pesquisador do Núcleo de Estudos e Pesquisas em Sexualidades (NEPSs) e do Núcleo de Estudos e Pesquisas sobre as Relações de Gênero (NUEPOM/UFMT). Email: pablocardoz@gmail.com.

\section{Sara Wagner York}

Doutoranda em Educação pela Universidade do Estado do Rio de Janeiro (UERJ). Mestra em Educação (GENI-ProPEd/UERJ). Graduada em Letras Inglês e Literaturas Estadunidense e Inglesa (Licenciatura / UNESA), Pedagogia (Licenciatura / UERJ ) e Letras Português e literaturas Brasileiras, Portuguesas 
e Africanas de Língua Portuguesa (Licenciatura /UNESA). E-mail: sarayork@ live.com.pt

\section{Tatiana Bezerra de Oliveira Lopes}

Graduada em Ciências Sociais pela Universidade Federal de Mato Grosso do Sul (FACH/UFMS) e mestranda em Antropologia Social pela Universidade Federal de Santa Catarina (PPGAS/UFSC). É membra do Núcleo de Estudos Néstor Perlongher - cidade, geração e sexualidade (NENP/ UFMS). Atualmente está vinculada ao Núcleo de Identidades de Gênero e Subjetividades (NIGS/UFSC). E-mail: tatianabezerralopes@gmail.com.

\section{Tatiana Lionço}

Doutora em Psicologia pela Universidade de Brasília (UnB). Professora do Departamento de Comunicação Organizacional da Faculdade de Comunicação da Universidade de Brasília (UnB). Pesquisadora do Núcleo de Estudos da Diversidade Sexual e de Gênero (NEDIG) do Centro de Estudos Avançados Multidiscplinares (CEAM). Email: tlionco@gmail.com 


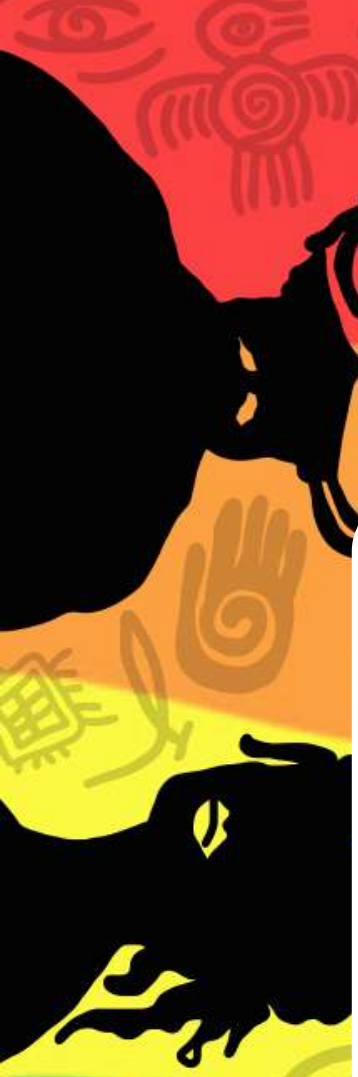

Ao completar 20 anos de coprodução de saberes acadêmicos, militantes e artísticos, a Associação Brasileira de Estudos da Homocultura $(A B E H)$, é reflexo do amadurecimento dos estudos de diversidade sexual e de gênero no Brasil. A ressonância da perspectiva interseccional, atenta à necessária correlação entre sexualidade, gênero, raça, etnia, geração, classe social e outros marcadores sociais da diferença vai arregimentar este solo fértil em que se constituiu esse campo de estudos. A circulação das produções germinadas fora dos grandes centros é um compromisso desse livro, resultante do trabalho da gestão 2019-2020 da ABEH, sediada em Mato Grosso. Entre margens e centro, no sentido foucaultiano, a obra envolve a crença nas alianças, na responsabilidade e no compromisso em comunicar e socializar o que também se produz fora do eixo.

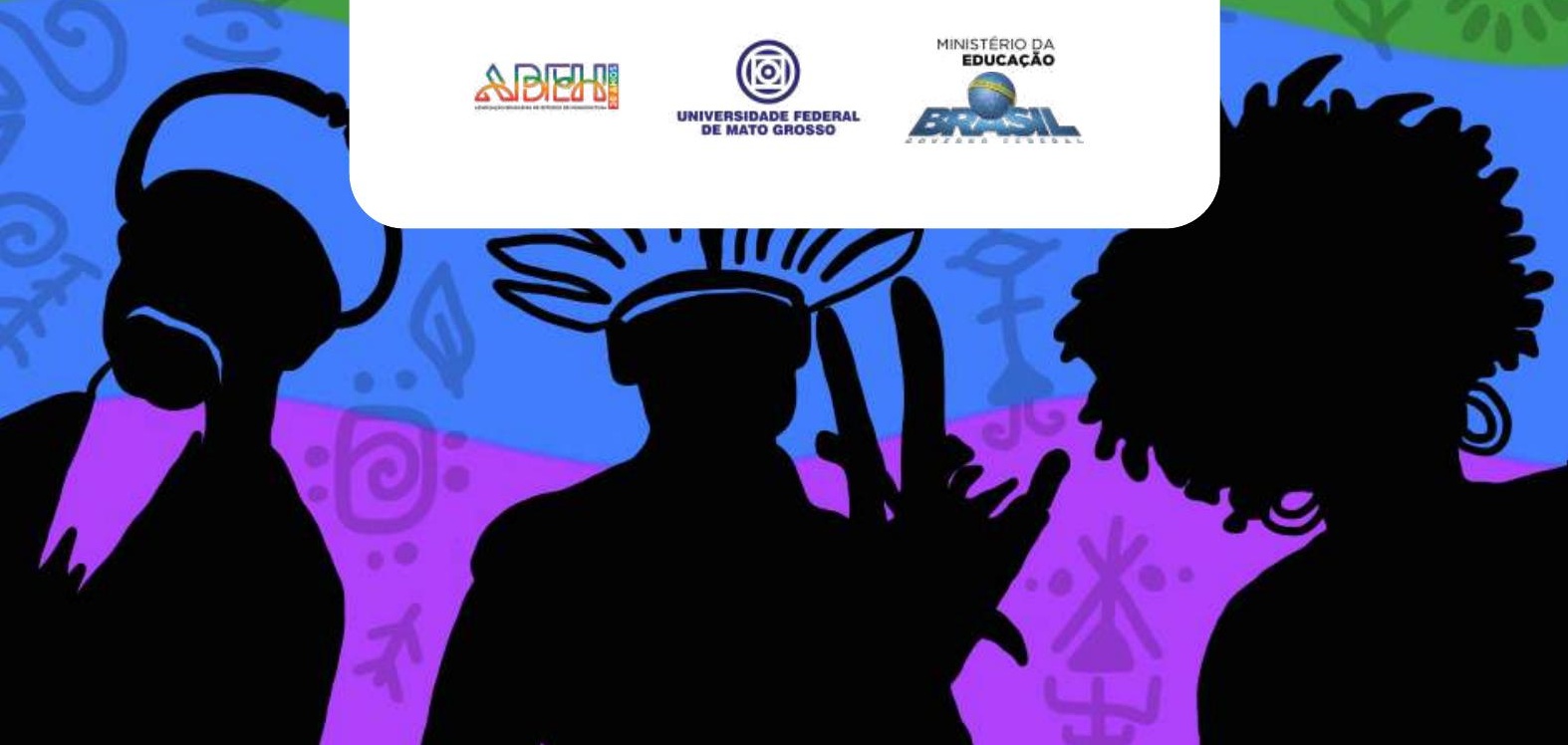

